\author{
UNIVERSIDADE DE SÃO PAULO \\ PROGRAMA INTERUNIDADES EM ENERGIA
}

ESCOLA POLITÉCNICA - FACULDADE DE ECONOMIA E ADMINISTRAÇÃO

INSTITUTO DE ELETROTÉCNICA E ENERGIA - INSTITUTO DE FÍSICA

ALEXANDRE UHLIG

\title{
MODELO CASCATA: UM INSTRUMENTO DE PLANEJAMENTO ENERGÉTICO APLICADO AO SETOR SUCRO-ALCOOLEIRO NO ESTADO DE SÃO PAULO
}

Dissertação apresentada ao Programa Interunidades de Pós Graduação em Energia da Universidade de São Paulo para a obtenção do título de Mestre em Energia.

São Paulo 


\author{
UNIVERSIDADE DE SÃO PAULO \\ PROGRAMA INTERUNIDADES EM ENERGIA
}

ESCOLA POLITÉCNICA - FACULDADE DE ECONOMIA E ADMINISTRAÇÃO

INSTITUTO DE ELETROTÉCNICA E ENERGIA - INSTITUTO DE FÍSICA

ALEXANDRE UHLIG

\title{
MODELO CASCATA: UM INSTRUMENTO DE PLANEJAMENTO ENERGÉTICO APLICADO AO SETOR SUCRO-ALCOOLEIRO NO ESTADO DE SÃO PAULO
}

\begin{abstract}
Dissertação apresentada ao Programa Interunidades de Pós Graduação em Energia da Universidade de São Paulo para a obtenção do título de Mestre em Energia.
\end{abstract}

Área de Concentração:

Energia

Orientador:

prof.Dr. Gilberto De Martino Jannuzzi

São Paulo 
U31m Uhlig, Alexandre $\quad$ Modelo cascata: um instrumento de planejamento energético aplicado ao setor sucro-alcooleiro no Estado de São Paulo / Alexandre Uhlig. - São Paulo: Programa Interunidades de Pós-Graduação em Energia, 1995. $154 \mathrm{p}$.

Dissertação(Mestrado) - Programa Interunidades de Pós-Graduação em Energia da Universidade de São Paulo. Escola Politécnica Faculdade de Economia e Administração - Instituto de Eletrotécnica e Energia - Instituto de Física

1. Planejamento energético 2. Biomassa - política energética 3. Energia - fontes alternativas I. Universidade de São Paulo. Programa Interunidades de Pós-Graduação em Energia da Universidade de São Paulo. Escola Politécnica - Faculdade de Economia e Administração Instituto de Eletrotécnica e Energia - Instituto de Física. II. Título

CDD - 620.9

CDU - 621.92 
Aos meus pais, por tudo que fizeram para dar-me uma educação digna.

E àvocê Li 


\section{A GR A DE CIMENTOS}

Ao orientador e amigo, prof. Gilberto Jannuzzi, pelas diretrizes seguras, orientações, incentivo constante e disponibilidade em ajudar sempre que necessário,

Ao Instituto de Eletrotécnica e Energia, aos professores, colegas e funcionários, pelas informações recebidas,

À CESP, aos superiores e colegas pelo crédito, incentivo e informações recebidas,

Às empresas e aos profissionais que nos auxiliaram na elaboração deste trabalho fornecendo informações e nos recebendo com interesse e atenção,

À Eliane, pelo amor, companhia, sacrifício de férias e fins de semana, ajuda na revisão, por tudo,

Aos meus pais, por terem acreditado em mim e feito investimentos, que muitas vezes não possuíam, na minha educação,

Ao meu amigo Noel e família, pela amizade e orientação sempre presentes em minha vida,

Aos meus irmãos, Álvaro e Aldo, pelo companherismo e amizade,

Aos meus amigos, pela paciência, incentivo e orientação,

minha gratidão e meu afeto. 


\section{S U M Á R I O}

Lista de tabelas

Lista de figuras

Lista de símbolos

\section{RESUMO}

\section{ABSTRACT}

1 INTRODUÇÃO

$1.1 \quad$ O planejamento energético no Brasil ..................................................





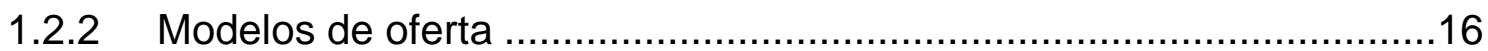

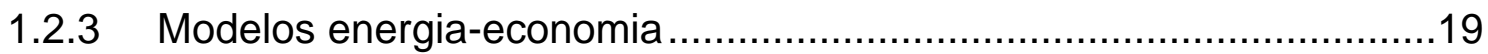

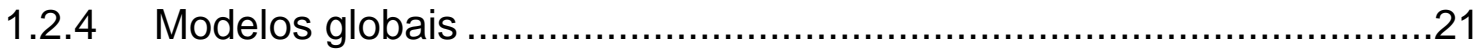

2 MODELO CASCATA: REFERENCIAL TEÓRICO ..............................24

2.1 Definição e características do modelo ...........................................25

2.2 Desenvolvimento do modelo ............................................................25

2.2.1 Balanço energético na forma de uma cascata de matrizes.................26

2.2.2 Descrição das matrizes ...........................................................27

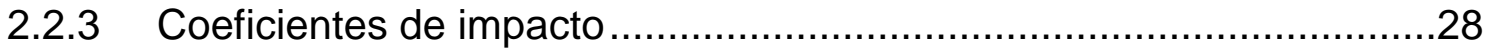

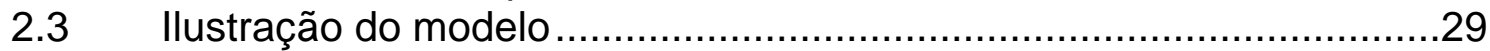



$2.5 \quad$ Limites do modelo ..............................................................

3 ESTUDO DE CASO: CANA-DE-AÇÚCAR E SEUS PRODUTOS .........34

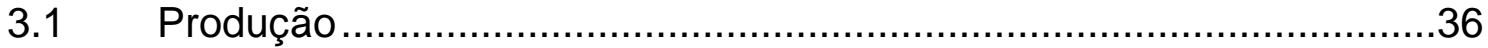

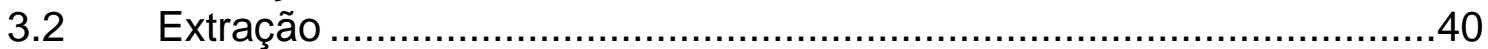

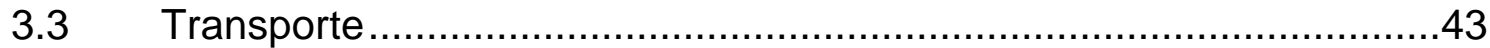



3.5 Transporte e distribuição …….................................................

3.5.1 Transporte e distribuição de álcool etílico ..........................................50

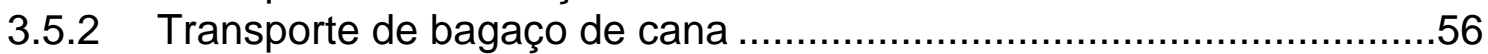

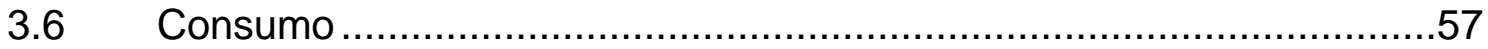

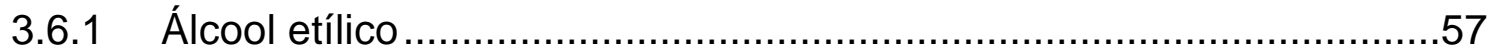

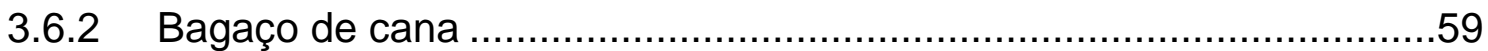

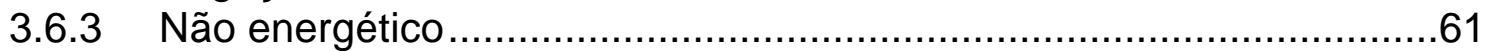

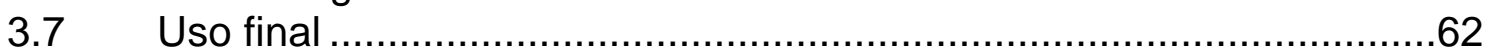

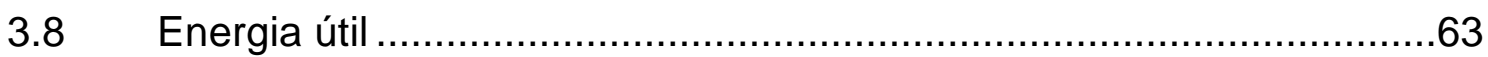

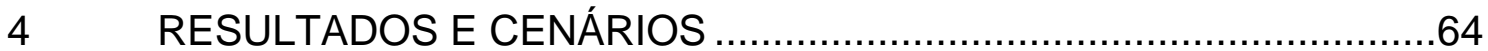

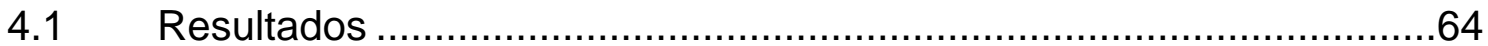

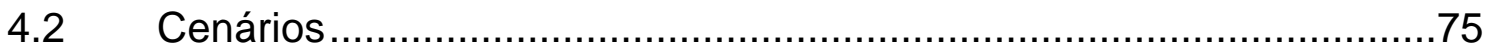

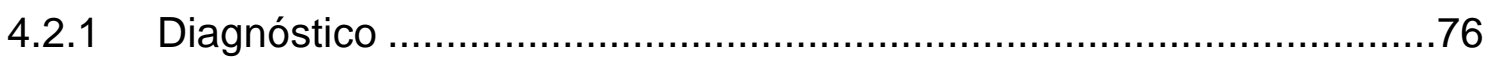

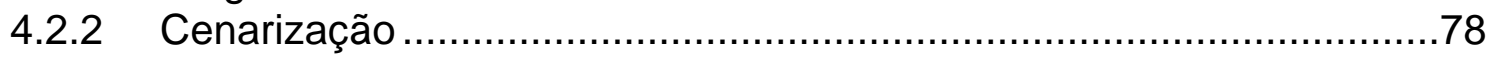




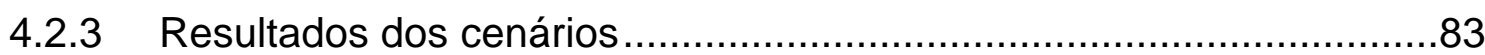

$5 \quad$ CONCLUSÕES E RECOMENDAÇÕES ..........................................94

5.1 O planejamento utilizando o modelo cascata....................................95

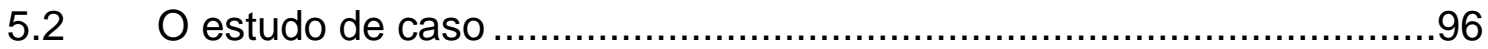

ANEXO A - Rendimento agrícola e industrial...................................98

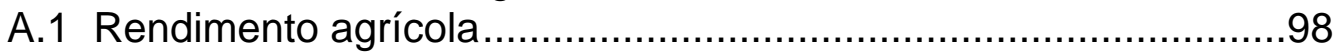

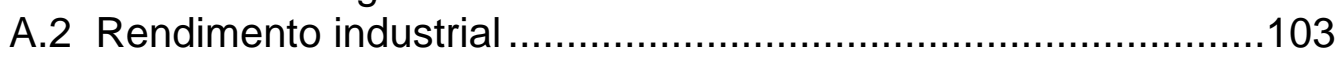

ANEXO B - Consumo de energia ................................................112

B.1 Operações agrícolas e colheita .............................................112

B.2 Transporte de cana-de-açúcar ............................................114

B.3 Transporte de álcool etílico ...............................................115

B.4 Transporte de bagaço de cana ...............................................117

ANEXO C - Fatores de emissão....................................................118



C.1.1 Operações agrícolas e colheita ...........................................121

C.1.2 Transporte de cana-de-açúcar ..........................................122

C.1.3 Transporte de álcool etílico ..............................................124





C.2 Fontes estacionárias....................................................129

C.2.1 Absorção de $\mathrm{CO}_{2}$ no crescimento da cana-de-açúcar ..............129

C.2.2 Queima de cana-de-açúcar no campo ..................................130

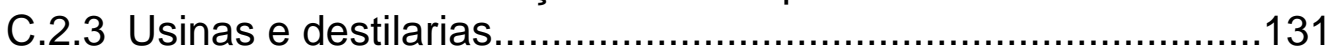

ANEXO D - Custos relativos àcana-de-açúcar e seus produtos........133

D.1 Transporte de cana-de-açúcar ..............................................134

D.2 Transporte de álcool etílico ...............................................134

D.3 Transporte de bagaço de cana.............................................136

ANEXO E - Transporte e distribuição de álcool etílico ......................138

REFERÊNCIAS BIBLIOGRÁFICAS E COMUNICAÇÕES PESSOAIS 144

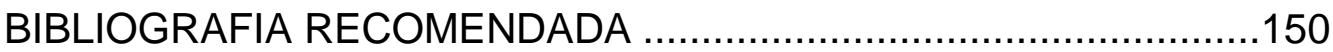

Apêndice I - Unidade, tabelas de conversão, preços e quantidade de energia

Apêndice II - Balanço energético do Estado de São Paulo, ano base 1991 


\section{Lista de tabelas}

TABELA 1.1 Classificação dos modelos de energia utilizados em planejamento energético.....................................................

TABELA 3.1 Distribuição de unidades agrícolas por nível tecnológico ........37

TABELA 3.2 Produtividade agrícola das usinas cooperadas àCopersucar .37

TABELA 3.3 Coeficientes de emissão para a fase agrícola.........................38

TABELA 3.4 Custo de produção de cana-de-açúcar, para o Estado de São Paulo, safra 1991/92 .........................................................39

TABELA 3.5 Consumo de energia na produção de cana-de-açúcar............40

TABELA 3.6 Coeficientes de emissão para extração de cana-de-açúcar no campo ........................................................................ 42

TABELA 3.7 Custo e consumo de energia em colheita de cana-de-açúcar.43

TABELA 3.8 Coeficientes de emissão para veículos utilizados em transporte de cana-de-açúcar ..................................................................44

TABELA 3.9 Custo e consumo de energia em transporte de cana-de-açúcar da lavoura até a unidade industrial..........................................45

TABELA 3.10 Distribuição de usinas e destilarias por tipo de instalação......47

TABELA 3.11 Distribuição de usinas e destilarias por nível tecnológico



TABELA 3.12 Custo de conversão de cana-de-açúcar em açúcar e álcool, para o Estado de São Paulo, safra 1991/92 ...........................48

TABELA 3.13 Consumo de energia na conversão de cana-de-açúcar em açúcar e álcool.

TABELA 3.14 Coeficientes de emissão para caminhões utilizados no transporte de álcool das usinas aos centros armazenadores primários

TABELA 3.15 Coeficientes de emissão para locomotivas utilizadas no transporte de álcool dos centros armazenadores primários ao centro armazenador secundário

TABELA 3.16 Coeficientes de emissão para empurradores utilizados no transporte de álcool 
TABELA 3.17 Coeficientes de emissão para caminhões utilizados no transporte de álcool das usinas ao centro armazenador secundário

TABELA 3.18 Coeficientes de emissão, consumo de energia e custo para caminhões utilizados na distribuição de álcool, por tipo de álcool 55

TABELA 3.19 Coeficientes de emissão para caminhões utilizados em transporte de bagaço de cana .56

TABELA 3.20 Evolução das exportações de álcool etílico produzido no Estado de São Paulo, em $10^{3} \mathrm{~m}^{3}$

TABELA 3.21 Coeficientes de emissão para queima de álcool hidratado em motores de ciclo Otto.

TABELA 3.22 Coeficientes de emissão para queima de bagaço de cana em caldeiras .63

TABELA 4.1 Produção, consumo e exportação de cana-de-açúcar e seus produtos no Estado de São Paulo em 1991

TABELA 4.2 Consumo de bagaço de cana no Estado de São Paulo por setor em 1991

TABELA 4.3 Distribuição das unidades agrícolas paulistas por nível tecnológico.

TABELA 4.4 Distribuição da colheita de cana-de-açúcar no Estado de São Paulo, por forma

TABELA 4.5 Distribuição do transporte de cana-de-açúcar, por tipo de veículo utilizado no Estado de São Paulo 66

TABELA 4.6 Distribuição das usinas e destilarias paulistas por nível tecnológico industrial.....

TABELA 4.7 Porcentagem da produção de álcool transportada das usinas aos centros armazenadores primários no Estado de São Paulo

TABELA 4.8 Porcentagem da produção de álcool transportada dos centros armazenadores primários ao centro armazenador secundário no Estado de São Paulo, por modal

TABELA 4.9 Distribuição dos veículos utilizados na distribuição de álcool etílico no Estado de São Paulo, por tamanho. 
TABELA 4.10 Distribuição dos veículos utilizados na distribuição de bagaço de cana no Estado de São Paulo, por tamanho .......................68

TABELA 4.11 Eficiência de conversão em energia útil, por uso final ............68

TABELA 4.12 Estimativas de emissão bruta provenientes do processo energético de cana-de-açúcar no Estado de São Paulo em 1991 , por fase e por poluente, $\left[10^{3} \mathrm{t}\right]$.....

TABELA 4.13 Contribuição relativa das fases para as emissões de poluentes, por poluente, [\%]

TABELA 4.14 Comparação entre as estimativas de emissões provenientes do processo energético da cana-de-açúcar e de regiões altamente poluídas, por poluente, $\left[10^{3} \mathrm{t}\right]$.

TABELA 4.15 Comparação entre as emissões por área provenientes do processo energético da cana-de-açúcar e de regiões altamente poluídas, por poluente, $\left[\mathrm{t} / \mathrm{km}^{2}\right]$ .71

TABELA 4.16 Consumo de energia no processo energético de cana-deaçúcar e seus derivados no Estado de São Paulo, por fase, $\left[10^{3} \mathrm{GJ}\right]$

TABELA 4.17 Custo de produção da cana-de-açúcar e seus derivados, e preço ao consumidor no Estado de São Paulo 74

TABELA 4.18 Comparação entre os custos de produção de cana-de-açúcar75

TABELA 4.19 Sinopse do diagnóstico do processo energético da cana-deaçúcar para o Estado de São Paulo em 1991 .77

TABELA 4.20 Composição porcentual da frota de automóveis, por categoria, do Estado de São Paulo em 1991, [\%] 78

TABELA 4.21 Composição porcentual da frota de automóveis, por categoria, do Estado de São Paulo em 2010 para o cenário ambiental, [\%] .80

TABELA 4.22 Composição porcentual da frota de automóveis, por categoria, do Estado de São Paulo em 2010 para o cenário tendencial, $[\%]$

TABELA 4.23 Composição porcentual da frota de automóveis, por categoria, do Estado de São Paulo em 2010 para o cenário reduzido, [\%]

TABELA 4.24 Sinopse das variáveis dos cenários propostos para a cana-deaçúcar e seus subprodutos para o Estado de São Paulo em 2010. 
TABELA 4.25 Produção, consumo e exportação de cana-de-açúcar e seus produtos no Estado de São Paulo em 2010, por cenário .84

TABELA 4.26 Variação porcentual da produção, consumo e exportação de cana-de-açúcar e seus produtos em 2010 comparado ao ano base $[\%]$.

TABELA 4.27 Estimativas de emissão bruta proveniente do processo energético da cana-de-açúcar no Estado de São Paulo em 2010, por poluente, $\left[10^{3} \mathrm{t}\right]$...... 88

TABELA 4.28 Variação porcentual da emissão bruta proveniente do processo energético da cana-de-açúcar no Estado de São Paulo em 2010 , por poluente, comparado ao ano base [\%].

TABELA 4.29 Consumo de energia no processo energético da cana-deaçúcar e seus derivados no Estado de São Paulo em 2010, $\left[10^{3} \mathrm{GJ}\right]$ 91

TABELA 4.30 Variação porcentual do consumo de energia no processo energético da cana-de-açúcar no Estado de São Paulo em 2010, comparado ao ano base [\%]

TABELA 4.31 Custo de produção dos derivados de cana-de-açúcar no Estado de São Paulo em 2010, [10 $0^{6}$ US\$] ..............................92

TABELA 4.32 Variação porcentual do custo de produção dos derivados de cana-de-açúcar no Estado de São Paulo em 2010, comparado ao ano base [\%].

TABELA A.1 Produção de cana-de-açúcar e rendimento agrícola de usinas e destilarias no Estado de São Paulo, safra 91/92 ..................98

TABELA A.2 Distribuição de usinas por rendimento agrícola ....................102

TABELA A.3 Rendimento industrial de usinas de açúcar no Estado de São Paulo safra 91/92..........................................................103

TABELA A.4 Distribuição de usinas de açúcar por rendimento industrial..103

TABELA A.5 Rendimento industrial de usinas de açúcar, com destilaria em anexo, no Estado de São Paulo, safra 91/92 104

TABELA A.6 Distribuição de usinas de açúcar, com destilaria anexa, por rendimento industrial na produção de açúcar e álcool 106

TABELA A.7 Rendimento industrial de destilarias autônomas no Estado de São Paulo, safra 91/92 107 
TABELA A.8 Distribuição de destilarias autônomas por rendimento industrial 109

TABELA C.1 Fatores de emissão de carbono e de dióxido de carbono.....118

TABELA C.2 Fatores de emissão da frota de veículos da Região Metropolitana de São Paulo em 1985..................................121

TABELA C.3 Fatores de emissão para tratores a óleo diesel.....................121

TABELA C.4 Capacidade e autonomia de caminhões utilizados em transporte de cana-de-açúcar............................................123

TABELA C.5 Volume de álcool etílico transportado na distribuição ............125

TABELA C.6 Fatores de emissão para locomotivas ................................126

TABELA C.7 Fatores de emissão médios para barcos comerciais em rios 127

TABELA C.8 Fatores de emissão para queima de cana-de-açúcar no campo .131

TABELA C.9 Fatores de emissão para caldeiras a bagaço de cana sem controle 132

TABELA E.1 Produção e consumo de álcool em milhares de $\mathrm{m}^{3}$, segundo regiões administrativas do Estado de São Paulo, em 1988 ..138

TABELA E.2 Distância média percorrida, ida e volta, por rodovia, de usinas aos centros armazenadores primários, no Estado de São Paulo em 1991 139

TABELA E.3 Distância média percorrida, ida e volta, por rodovia, de usinas ao centro armazenador secundário, no Estado de São Paulo em 1991 140

TABELA E.4 Distância média percorrida, só ida, em ferrovia por tipo de tração, de centros armazenadores primários ao centro armazenador secundário, no Estado de São Paulo em 1991141

TABELA E.5 Distribuição dos caminhões da Shell utilizados em entrega de combustíveis das bases aos postos de combustíveis na Grande São Paulo 142

TABELA E.6 Distribuição do transporte de álcool por modal para o Estado de São Paulo em 1991 143

TABELA I.1 Multiplicadores de base decimal.........................................

TABELA I.2 Fatores de conversão de unidades .......................................1 
TABELA I.3 Preço dos energéticos por unidade comercial...........................2

TABELA I.4 Quantidade de energia por unidade comercial........................2

TABELA I.5 Massa específica, poder calorífico inferior e coeficientes de

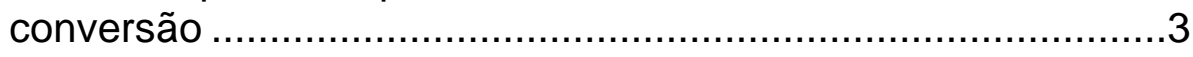




\section{Lista de figuras}

Fig. 2.1 Balanço energético na forma de uma cascata de matrizes de

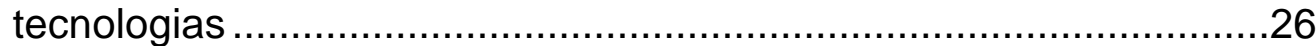

Fig. 2.2 Emissões total de $\mathrm{SO}_{2}$ para uma das matrizes ................................28

Fig. 2.3 Balanço ambiental calculado a partir da cascata de matrizes do

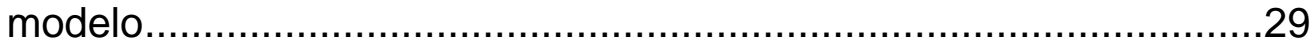

Fig. 2.4 Aplicação do modelo cascata, República Federal Alemã, 1985 .........30

Fig. 2.5 Modelo cascata utilizado na previsão de impactos ambientais...........31

Fig. 3.1 Modelo cascata para cana-de-açúcar e seus produtos ......................35

Fig. 3.2 Esquema simplificado da produção de açúcar e álcool em usinas....45

Fig. 3.3 Sistema transportador e armazenador de álcool ................................54

Fig. 3.4 Evolução das exportações de álcool etílico produzido no Estado de

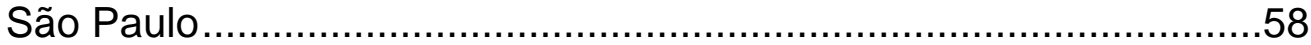

Fig. 3.5 Evolução do consumo de álcool etílico, por setor, no Estado de São Paulo

Fig. 3.6 Evolução do consumo de bagaço de cana, por setor, no Estado de São Paulo.

Fig. 3.7 Evolução do consumo de açúcar no Estado de São Paulo.

Fig. 4.1 Produção de álcool hidratado x produção de álcool anidro no Estado de São Paulo, em porcentagem

Fig. 4.2 Evolução da produção de cana-de-açúcar no Estado de São Paulo, em diversos cenários

Fig. 4.3 Evolução da produção de álcool no Estado de São Paulo, em diversos cenários

Fig. 4.4 Evolução do consumo de álcool e gasolina no Estado de São Paulo, em diversos cenários

Fig. 4.5 Evolução da produção e do consumo de açúcar no Estado de São Paulo, em diversos cenários

Fig. 4.6 Evolução das emissões de monóxido de carbono e hidrocarbonetos no Estado de São Paulo, em diversos cenários. 
Fig. 4.7 Evolução das emissões de material particulado e óxidos de nitrogênio no Estado de São Paulo, em diversos cenários .................................90

Fig. 4.8 Evolução das emissões de óxidos de enxofre e aldeídos no Estado de

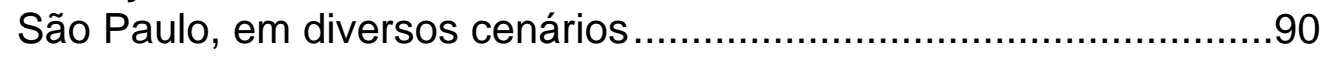

Fig. 4.9 Evolução das emissões de dióxido de carbono no Estado de São Paulo, em diversos cenários .91

Fig. A.1 Distribuição de usinas por rendimento agrícola .............................102

Fig. A.2 Distribuição de usinas de açúcar por rendimento industrial ............104

Fig. A.3 Distribuição de usinas de açúcar com destilaria anexa por rendimento industrial na produção de açúcar 106

Fig. A.4 Distribuição de usinas de açúcar com destilaria anexa por rendimento industrial na produção de álcool 107

Fig. A.5 Distribuição de destilarias autônomas por rendimento industrial.....110 


\section{Lista de abreviaturas, siglas e símbolos}

Procurando facilitar o tratamento dos dados, foram adotados algumas abreviaturas, siglas e símbolos, eles estão aqui listados visando orientar o leitor.

A.A. - álcool anidro

A.H. - álcool hidratado

AIAA - Associação das Indústrias de Açúcar e Álcool do Estado de São Paulo aut - autonomia do veículo

BEN - Balanço Energético Nacional

$\mathrm{ce}_{(\mathrm{c})}$ - fator de emissão de carbono

CEREN - Centro de Estudos e Pesquisa em Energia

Cesp - Companhia Energética de São Paulo

$\mathrm{CH}_{4}$ - metano

CNP - Conselho Nacional de Petróleo

$\mathrm{CO}$ - monóxido de carbono

$\mathrm{CO}_{2}$ - dióxido de carbono

con - consumo médio

Copersucar - Cooperativa de produtores de cana, açúcar e álcool do Estado de São Paulo Ltda.

d - dia

dm - distância média

$E_{\mathrm{ac}}$ - consumo de óleo diesel em operações agrícolas e de colheita

ea ${ }_{u c}$ - quantidade de energia por litro de álcool

eb $b_{u c}$ - quantidade de energia por tonelada de bagaço de cana

Ecc - consumo de óleo diesel em colheita mecânica

Ecm - consumo de óleo diesel em colheita manual

$\mathrm{ec}_{\mathrm{uc}}$ - quantidade de energia por tonelada de cana

ed $\mathrm{du}_{\mathrm{uc}}$ - quantidade de energia por litro de óleo diesel

EFOM - Energy Flow Optimization Model

EIA - Estudo de Impacto Ambiental

$E_{m a}$ - consumo de óleo diesel em colheita manual

$E_{m e}$ - consumo de óleo diesel em colheita mecanizada

$E_{o a}$ - consumo de óleo diesel em operações agrícolas na fase de produção

Ep - consumo de óleo diesel em operações agrícolas na cana-planta

EPA - Environmental Protection Agency

Es - consumo de óleo diesel em operações agrícolas na cana soca

ETA - Energy Technology Assessment

fe - fator de emissão

faco $_{2}$ - fator de absorção de dióxido de carbono

$\mathrm{feCO}_{2}$ - fator de emissão de dióxido de carbono

FGV- Fundação Getúlio Vargas

ha - hectare $=0,01 \mathrm{~km}^{2}=10.000 \mathrm{~m}^{2}$

$\mathrm{HC}$ - hidrocarboneto

$\mathrm{HCHO}$ - aldeído

$\mathrm{hm}$ - homem 
IAA - Instituto do Açúcar e do Álcool

IAEA - International Atomic Energy Agency

IBRD - International Bank for Reconstruction and Development

IBRE - Instituto Brasileiro de Economia

IEA - International Energy Agency

IIASA - International Institute for Applied Systems Analysis

IPCC - Intergovernmental Panel on Climate Change

KLEM - capital stocK, Labor, Energy, raw Material

la - litros de álcool

$l a_{v}$ - quantidade de álcool transportada por viagem

Id - litros de diesel

ma - máquina agrícola

MEB - Matriz Energética Brasileira

MEDEE - Modèle d'évolution de la demande d'énergie

MME - Ministério das Minas e Energia

MP - material particulado

MREEED - Multi Regional Model of the Economy, Environment, and Energy

Demand

MSEDM - Minimum Standard Energy Demand Model

nd - informação não disponível

NIMFEA - Méthode Normative des Impacts Macroéconomiques des Filières

Énergétiques Alternatives

NOx - óxidos de nitrogênio

OECD - Organization for Economic Cooperation and Development

OLADE - Organização Latino-Americana de Energia

OPET - Organizations for the Promotion of Energy Technology

$\mathrm{Pa}$ - produtividade agrícola anual

PASP - Plano de Ação do Setor Petróleo

pd - preço do óleo diesel

pe - preço de energético

PIB - Produto Interno Bruto

Replan - Refinaria do Planalto

RFF - Resourse for the Future

RIMA - Relatório de Impacto Ambiental

RMSP - Região Metropolitana de São Paulo

s/d - sem data

sc - saca com $50 \mathrm{~kg}$ de açúcar

Serplan - Serviço de Planejamento da Petrobrás

SIMA - Simulation of Macroeconomic Scenarios to Access Energy Demand

SOx - óxidos de enxofre

ta - tonelada de açúcar

tb - tonelada de bagaço de cana

$\mathrm{tb}_{\mathrm{v}}$ - quantidade de bagaço de cana transportada por viagem

tC - tonelada de cana-de-açúcar

$\mathrm{tC}_{\mathrm{v}}$ - quantidade de cana-de-açúcar transportada por viagem

tEP - tonelada equivalente de petróleo

uc - unidade comercial

vel - velocidade média 
vi - valor incompatível

WAES - Workshop on Alternative Energy Strategies

WASP - Wien Automatic System Planning Package 


\section{RES U M O}

O modelo cascata, desenvolvido por consultores europeus e não difundido no Brasil, é formado por matrizes onde as colunas descrevem as tecnologias e as linhas as fontes de energia, e representa um completo balanço energético incluindo as tecnologias utilizadas na produção, extração, conversão, transporte e uso final.

A avaliação quantitativa dos impactos e dos custos envolvidos é feita por intermédio de coeficientes de impactos e de custos, ou seja, cada matriz do balanço energético é multiplicada por sua correspondente matriz de coeficientes de impactos e de custos.

O modelo, devido a sua construção, permite ainda simular cenários prospectivos a partir de informações obtidas em planos ou programas oficiais.

Um levantamento histórico do planejamento energético no Brasil e dos modelos de energia utilizados em planejamento energético ajudaram a verificar a necessidade e a compreender melhor a concepção de instrumentos que auxiliem na tomada de decisão no setor energético brasileiro.

Um estudo de caso, para o estado de São Paulo em 1991, utilizando a canade-açúcar como energético, foi elaborado a fim de ilustrar a utilidade do modelo cascata. A partir dos valores obtidos no balanço energético, foram elaborados três cenários prospectivos, que fornecem subsídios para a análise do futuro do setor sucro-alcooleiro. 


\section{A B S T R A C T}

The cascade model was developed by European consultants but it has not been available in Brazil. It is formed by matrices where columns represent types of technology and the rows represent types of energy. The resulting cascade of matrices represents a complete energy balance including all types of technology applied in the chain of extraction, conversion and use.

The quantitative assessment of impacts and costs is made by the impacts and costs coefficients. For this purpose each of the energy balance matrices has to be multiplied by a corresponding matrix of impact and cost coefficients.

The cascade model allows us to simulate scenarios with information obtained from official plans or programs.

A historical survey of energy plan in Brazil, and of energy models, aid to check and to understand better the creation of tools that help decision makers and planning authorities in the Brazilian energy sector.

A case study, for São Paulo State in 1991, using sugar cane as a type of energy, was made in order to show the utility of the cascade model. From the values obtained in the energy balance three scenarios were developed that provide assistance for the analysis of the future of the alcohol sector. 


\section{INTRODUÇÃO}

O crescente uso de energia alterou a qualidade do ar e da água, acirrou a disputa por terras, deslocou populações, proliferou a energia nuclear e pode modificar o clima. Para os países que precisaram importar petróleo e carvão para atender esta demanda de energia, significou também um pesado ônus sobre a balança econômica. Além da dívida externa provocada pela importação de energéticos, os investimentos em suprimento de energia: exploração, construção de usinas, que são altamente intensivos em capital, agravaram ainda mais a situação econômica dos países em desenvolvimento (GOLDEMBERG, 1988).

Segundo NIJKAMP; VOLWAHSEN (1990), os impactos da produção, conversão e uso de energia sobre o setor econômico e deste sobre o setor energético já foram suficientemente estudados e analisados nas recentes décadas. Trabalhos que relacionam modelos baseados em teoria econômica e descrevem seus resultados demonstram isto. LAPILLONNE (1990) afirma que devido à simplicidade dos modelos econométricos, que utilizam indicadores macroeconômicos para calcularem a demanda de energia, eles ainda são utilizados por organismos internacionais como a International Energy Agency (IEA) e em estudos para países em desenvolvimento. Na comparação feita por DIJK; KOK (1987) entre quatro modelos diferentes aplicados à Holanda, todos discutiam os efeitos do crescimento econômico e dos preços dos energéticos sobre o setor energético.

Embora o setor energético fosse uma das maiores fontes de poluição em todo o mundo, os impactos sobre o meio ambiente apesar de conhecidos só passaram a ser devidamente considerados no Brasil no final da década de 80 (JANNUZZI, 1991). Devido a deterioração ambiental provocada pelo uso de energia, através da emissão de poluentes, inundação de áreas, deslocamento de população, os impactos ambientais passam a ser intensamente estudados e controlados por legislação. No Brasil, a obrigatoriedade de apresentação de Estudo de Impacto Ambiental (EIA) a partir de 1986 significou uma considerável conquista, pois possibilitou introduzir nos projetos de empreendimentos a viabilidade ambiental, 0 que evitará investimentos futuros em equipamentos de controle e monitoramento 
reduzindo assim os efeitos sobre o meio ambiente e conseqüentemente sobre a população (SECRETARIA DO MEIO AMBIENTE, 1991).

Apesar desta preocupação, ainda são poucos os instrumentos de análise integrada entre energia e meio ambiente desenvolvidos recentemente. De quatorze modelos ambientais integrados estudados por BROUWER (1987) apenas dois relacionam energia e meio ambiente, os demais tratam de aspectos relacionados ao uso da água (qualidade da água, escassez de água, ou enchentes) e ao uso do solo (atividades agrícolas e planejamento regional).

Uma realística avaliação dos impactos sobre o meio ambiente deve considerar todos os estágios do processo de conversão de energia, desde a produção até o uso final. Os estudos disponíveis, freqüentemente limitam sua atenção a uma ou outra parte da cadeia do processo de conversão de energia e deste modo não permitem tirar conclusões abrangentes. Os dados de produção, demanda e consumo de energia obtidos junto às empresas de serviço público, indústrias e usuários de energia estão relacionados entre si, permitem compreender melhor as relações existentes entre causa e efeito, e se trabalhados convenientemente fornecem uma primeira indicação de problemas que deverão ser analisados profundamente em cada fase do processo energético.

Por estas razões, o planejamento energético deve considerar desde o início variáveis ambientais, sociais e econômicas, e utilizar modelos simples que permitam ao decisor investigar uma ampla gama de situações.

Neste trabalho, é estudado e mostrado a aplicabilidade de um modelo, desenvolvido por consultores europeus e não difundido no Brasil, no planejamento energético brasileiro, tendo em vista que o modelo cascata considera as tecnologias utilizadas, as fontes de energia, os impactos ambientais e os custos envolvidos em todo processo energético, desde a produção até o uso final.

O modelo, devido a sua construção, permite simular cenários prospectivos a partir de informações obtidas em planos ou programas oficiais oferecendo ao planejador dados que o auxiliem na tomada de decisões.

Este trabalho inicia-se com a história e o modo de elaboração do planejamento energético no Brasil. Neste mesmo capítulo são estudados também os modelos de energia utilizados em planejamento energético. 
Em seguida, é proposta uma abordagem que, além da oferta e da demanda de energia, também considera as tecnologias utilizadas e os impactos ambientais por elas provocados: o modelo cascata. Neste capítulo o modelo cascata é descrito e conceituado, fornecendo subsídios à elaboração, nos capítulos seguintes, de um estudo de caso.

O estudo de caso é elaborado a fim de ilustrar a aplicabilidade do modelo; para isto utilizou-se dados referentes aos produtos energéticos da cana-de-açúcar. Como resultados foram obtidos: o balanço energético da cana-de-açúcar para o Estado de São Paulo em 1991, a emissão atmosférica bruta em cada fase do processo de conversão de energia, os custos e os insumos energéticos utilizados. A partir destes resultados são propostos e discutidos cenários para o ano 2010, onde se procurou, após um diagnóstico da situação, investigar várias políticas em diversos contextos.

\subsection{O planejamento energético no Brasil}

Em 1989, o Brasil consumiu 86,27 milhões de tEP (OCDE, 1992 b), cerca de 3\% da energia consumida nos países membros da Organização para Cooperação Econômica e Desenvolvimento (OCDE) ${ }^{1}$. O consumo per capita brasileiro, neste mesmo ano (1989), foi 0,59 tEP/habitante, (OCDE, 1992 b), que, se comparado à média dos países membros da OCDE, 3,44 tEP/habitante (OCDE, 1991 a), é pequeno, porém, nos últimos 10 anos, cresceu 15,6\%, enquanto que nos países da OCDE, no mesmo período, permaneceu estável.

Em termos de investimento, o setor energético brasileiro chegou a consumir, em 1988, 50\% dos investimentos públicos (GOLDEMBERG, 1988), o que correspondeu, segundo MONACO (1989) à 3,6\% do PIB. Grande parte destes investimentos foram feitos em moeda estrangeira. Do total dos investimentos, 0 setor elétrico, em 1987, investiu, com recursos próprios, 28\% (MONACO, 1989).

\footnotetext{
${ }^{1}$ A OCDE reúne os seguintes países membros: Alemanha, Áustria, Austrália, Bélgica, Canadá, Dinamarca, Finlândia, Grécia, Irlanda, Islândia, Itália, Japão, Luxemburgo, Holanda, Nova Zelândia, Noruega, Portugal, Espanha, Suécia, Suíça, Turquia, Estados Unidos e Reino Unido.
} 
O uso de energia, apesar de, em geral, melhorar a qualidade de vida da população, proporcionar conforto, gerar divisas e riquezas ao país, tem seus problemas: o esgotamento e a destruição dos recursos naturais, a poluição do ar e da água, as disputas por terra, os deslocamentos populacionais e a possibilidade de alterações no clima.

O volume de energia comercializada, os altos investimentos e os impactos sobre o meio ambiente, são alguns dos motivos que fazem o setor energético brasileiro ser de grande importância e por isso busca-se investigar a história e como é feito o planejamento energético nacional neste trabalho. A análise de como é feito 0 planejamento energético nacional permite propormos um modelo que procure atender as necessidades urgentes, sem sobreposições. Logo, o estabelecimento de uma política energética, onde estivessem definidas e fossem respeitadas estratégias a médio e longo prazo, surge como uma necessidade urgente visando promover a utilização racional das diversas formas de energia e a otimização do seu suprimento. Mas para isto é fundamental a implementação de um processo de planejamento que contemple todo o setor energético, buscando uma visão integrada, e não apenas setorial.

Um importante passo dado na direção do planejamento integrado foi a elaboração dos estudos prospectivos de energia. No Brasil, segundo PATUSCO (s/d), eles se iniciam em 1970 com a elaboração da Matriz Energética Brasileira - MEB, cujo objetivo era: "O estudo integrado das diversas formas de energia, em âmbito nacional, desde a produção e geração até o consumo final, permitindo dotar o país de um eficiente instrumento de planejamento para o setor energético como um todo".

O projeto da matriz energética brasileira além de preparar a matriz energética para 1970 e projetá-la de 5 em 5 anos até 1985, caracterizou-se por ser bastante abrangente, envolvendo estudos bem diversos como:

- análise de trabalhos realizados em outros países,

- análise interativa dos efeitos das variações econômicas sobre o sistema energético,

- avaliação da substituição entre fontes primárias de energia, 
- coleta de dados junto às fontes primárias de energia e pesquisa de campo, por amostragem, para identificar o consumo de energia em cada setor.

Em 1991, através de decreto, a matriz energética brasileira foi reexaminada a fim de orientar a elaboração da política energética nacional e os planos setoriais na área energética, conforme o RELATÓRIO da comissão constituída através do Decreto $n^{\circ}$ 99.503, de 02.09 .90 (1991).

Outro trabalho que buscava colaborar com o planejamento energético integrado foi o Balanço Energético Nacional - BEN. Instituído em 1976, com ele o Brasil ingressou nos países que buscavam ter uma base organizada de estatísticas sobre energia.

O balanço energético possibilita uma melhor compreensão das relações existentes entre energia, economia e sociedade, permitindo um melhor planejamento da expansão do aparelho de produção e transformação de energia (BICALHO, 1986). Apesar desta importância do balanço energético, enquanto quadro contábil que explicita o comportamento dos fluxos de energia e permite a atuação sobre este sistema, ele não vem sendo utilizado desta forma, nem combinado com modelos de previsão de demanda, que forneceriam ao planejador informações suficientes para a proposição de medidas que culminariam com o equilíbrio da balança energética.

Originalmente $\mathrm{o}$ balanço energético nacional foi concebido para retratar a evolução energética nos últimos dez anos e apresentar estudos das tendências energéticas para os próximos dez, isto ocorreu em apenas três balanços, 1976, 1977 e 1978. A partir de 1979, com a elaboração do Modelo Energético Brasileiro, - BEN deixou de apresentar projeções. O modelo energético brasileiro foi elaborado com o fim específico de identificar os requisitos básicos de energia para o período 1980/85. O modelo energético brasileiro foi editado em duas ocasiões, 1979 e 1981, e caracterizaram-se por apresentar como premissas básicas: substituir derivados de petróleo por fontes alternativas, aumentar a produção interna de petróleo e conservar energia. 
Em 1990, a pedido do Ministério das Minas e Energia (MME), foi elaborado um estudo para o sistema energético nacional pela Companhia Energética de São Paulo (Cesp) utilizando o Modèle d'évolution de la demande d'énergie (MEDEE)². Apesar de todas as iniciativas para o planejamento integrado, quem tem conduzido o planejamento energético no Brasil são basicamente dois setores: o elétrico e o petróleo. Cada um deles tem dado ênfase à expansão do seu sistema supridor de energia e, como conseqüência, não há uma política energética unificada para o Brasil.

No setor elétrico, até o início da década de 60 , não havia coordenação dos planejamentos das diversas concessionárias. As empresas atuavam independentemente, pois as interligações entre elas eram insignificantes, em sua maioria distribuíam a energia elétrica que geravam.

Com a crescente interdependência entre as empresas de energia elétrica em virtude das interligações elétricas, tornou-se necessária uma visão conjunta e a otimização da seqüência de obras. A partir de 1974, devido a importância da energia elétrica frente à đoise do petróleo, a Eletrobrás passa a coordenar planos de âmbito nacional com a participação de empresas regionais e estaduais. Os dois últimos planos 2010 e 2015, este último concluído em 1994, foram elaborados para servirem de referência para a expansão dos sistemas elétricos brasileiros e balizadores do atendimento ao mercado de energia elétrica.

Ao longo deste período, a evolução dos estudos de planejamento para o setor elétrico foi extremamente rica, foram introduzidas novas variáveis, como impactos ambientais, e os conceitos empregados revistos a fim de aproximar cada vez mais a situação simulada da realidade (ERBER, 1989).

No setor petróleo o primeiro instrumento legal de planejamento, na década de 50, foi o Plano Anual de Atividades elaborado pela Petrobrás apresentado anualmente ao Conselho Nacional de Petróleo (CNP). No início o planejamento limitava-se ao curto-prazo e a ênfase era dada às atividades de exploração e produção de petróleo visando a auto-suficiência. Na década de 60 , com a constatação de que

2 O MEDEE é um modelo de usos finais desenvolvido por CHATEAU; LAPILLONNE (1977) apud LAVERGNE (1990) para avaliar a demanda futura 
as bacias terrestres não ofereciam resultados satisfatórios, passou a dar atenção às atividades de refino e transporte e reorientaram a exploração para o mar. Em 1966, com a criação do Serviço de Planejamento (Serplan), órgão central de atividade de planejamento da Petrobrás, um grande passo foi dado na direção do planejamento a longo prazo, que culminaria em 1969 com a aprovação do primeiro estudo de longo prazo: "Projeção de Demanda Nacional de Derivados de Petróleo", cujo horizonte de projeção era 10 anos. Devido a descoberta de petróleo em bacias marítimas no início dos anos 70, a Petrobrás passa a desenvolver estudos de natureza prospectiva, também com horizonte de 10 anos. Neste período foram desenvolvidos diversos planos de longo prazo, porém não de forma integrada e coordenada.

Atualmente, o ciclo de planejamento do setor petróleo é anual, com horizonte de 10 anos. O Plano de Ação do Setor Petróleo (PASP), elaborado anualmente, é preparado num processo formal e sistemático, e prevê a possibilidade de atingir a auto-suficiência nacional na produção de petróleo no final deste século. (ENCARNAÇÃO JR, 1989)

\subsection{Modelos de energia}

Estudar os modelos de energia é fundamental, pois servem de referência ao modelo desenvolvido neste trabalho e dá ao leitor uma base a partir da qual é possível fazer uma avaliação mais crítica e fundamentada do objeto deste trabalho: o modelo cascata. Os modelos de energia utilizados em planejamento energético aqui relacionados, desenvolvidos, avaliados e utilizados em vários países, foram pesquisados através de revisão bibliográfica.

O papel dos modelos de energia utilizados em planejamento é definido, convenientemente, por ARAÚJO (1988):

"Modelos são representações da realidade; num sentido amplo, portanto, toda análise da realidade envolve modelos: modelos mentais, verbais, analógicos,

de energia. 
formalizados. Estes últimos são o que nos interessará neste texto, e em particular modelos implementáveis por computador.

Pode dizer-se que um modelo incorpora uma teoria sobre a realidade. ...é empregado para extrair inferências sobre o comportamento de um aspecto do real sem ter de agir sobre este último;...

...modelos para planejamento incorporam um aspecto adicional...o de investigar conseqüências de determinadas ações sobre a realidade, com vistas a orientar uma tomada de decisão.

...um modelo é sempre uma simplificação da realidade, não é a própria realidade. Com efeito, um modelo que contivesse todos os aspectos da realidade não se distinguiria desta última quanto às dificuldadesde manipulação e de análise. Para cumprir sua função de instrumento de investigação e de ajuda aos decisores, um modelo deve ser substancialmente mais simples que a realidade...".

A fim de organizar a apresentação, os modelos são classificados, conforme a tabela 1.1, segundo a sua principal finalidade em quatro categorias.

TABELA 1.1 Classificação dos modelos de energia utilizados em planejamento energético

\begin{tabular}{l|lll|c}
\hline \multicolumn{1}{c|}{ Modelos de energia } & \multicolumn{1}{|c|}{ Finalidades } & Métodos utilizados \\
\hline Modelos de demanda & $\begin{array}{l}\text { Analisar as variáveis e a } \\
\text { estrutura da demanda }\end{array}$ & $\begin{array}{c}\text { econométrico } \\
\text { técnico-econômico } \\
\text { insumo-produto }\end{array}$ \\
\hline Modelos de oferta & $\begin{array}{l}\text { Identificar combustíveis } \\
\text { tecnologias utilizadas }\end{array}$ & $\begin{array}{c}\text { otimização } \\
\text { simulação }\end{array}$ \\
\hline Modelos energia- & $\begin{array}{l}\text { Analisar impactos e } \\
\text { economia }\end{array}$ & $\begin{array}{l}\text { relações entre } \\
\text { energético e a economia }\end{array}$ & $\begin{array}{c}\text { simulação/otimização } \\
\text { econométrico } \\
\text { insumo-produto }\end{array}$ \\
\hline Modelos globais & $\begin{array}{l}\text { Projetar a demanda de energia } \\
\text { para regiões ou grupos de } \\
\text { países e apontar alternativas } \\
\text { para a situação atual }\end{array}$ & $\begin{array}{c}\text { integração de } \\
\text { modelos de oferta e } \\
\text { demanda } \\
\text { cenarização }\end{array}$ \\
\hline
\end{tabular}

Fonte: REUTER; VOSS (1990) 


\subsubsection{Modelos de demanda}

Os modelos de demanda são construídos com a finalidade de estudar os setores consumidores de energia e o crescimento do consumo nos seguintes níveis:

- energia final: refere-se a energia entregue ao consumidor, exemplo: eletricidade, gás, lenha, derivados de petróleo.

- energia útil: refere-se ao tipo de energia necessária ao serviço que o consumidor deseja obter: calor, energia cinética.

- serviço: refere-se ao serviço necessário aos consumidores, resultado da utilização da energia útil, como temperatura ambiente, cocção, deslocamento.

Os modelos de demanda também podem ser subdivididos em função dos métodos utilizados. Os métodos mais utilizados nos modelos de demanda são: econométrico, insumo-produto e técnico-econômico ou contábil.

\section{Modelos econométricos}

Os modelos de demanda que utilizam o método econométrico, em geral, são de simples concepção. Os modelos econométricos utilizam indicadores macroeconômicos, como: PIB, preços, renda, para calcular a demanda de energia. A estrutura mais utilizada é conhecida como modelo de dupla elasticidade, onde a demanda de energia é calculada a partir da renda (A) e, em alguns casos, dos preços de energia $(P)$. A relação matemática que a descreve é:

$$
E=A^{a} \cdot P^{b}
$$

Onde a e b são as elasticidades de renda e preço, respectivamente.

Depois de 1973, as radicais mudanças ocorridas na economia e no consumo de energia mostraram que os modelos econométricos não eram capazes de contabilizar satisfatoriamente os efeitos de um rápido aumento nos preços de energia, nem a mudança das estruturas econômicas sobre a demanda de energia. Entretanto, devido sua simplicidade eles ainda são utilizados por organismos internacionais como a Internacional Energy Agency (IEA) e em estudos para países em desenvolvimento a fim de obter inferências a respeito do comportamento da demanda (SAMOUILIDIS; MITROPOULOS, 1984). 
Um dos fatores limitantes dos modelos econométricos são as elasticidades preço e renda utilizadas na relação matemática. As variações dos preços em economias não estáveis ou em períodos de crise não conseguem ser representadas, ficando difícil estabelecer uma relação entre consumo de energia e preços. Além disto, uma grande importância é dada à variação de preços, desprezando outros fatores que afetam a demanda de energia como por exemplo medidas de conservação de energia, melhoria da qualidade dos combustíveis, mudanças tecnológicas, racionamentos estabelecidos pelo governo, o que resulta em valores de elasticidade subestimados (KOURIS, 1983a).

O crescimento econômico, outro indicador considerado por modelos econométricos, também apresenta dificuldades em ser contabilizado. Como exemplo, pode-se citar a substituição de energia não comercial (lenha) por comercial (eletricidade, óleo diesel) em países em desenvolvimento. Esta substituição de combustível não aumenta a renda mas o consumo contábil de energia, distorcendo, portanto, o valor da elasticidade calculada.

Devido a estes motivos, vários esforços no sentido de modificar os modelos econométricos tradicionais têm sido feitos. Um primeiro passo, foi melhorar a representação da relação energia - renda. Energia e renda foram desagregadas em modelos até onde as estatísticas permitissem; um exemplo disto é o modelo SIBILIN (CRIQUI, 1985 apud LAPILLONNE, 1990).

Outra forma de aprimorar o modelo foi distinguir os prazos considerados para os preços em curto e longo. As demandas de energia a curto e a longo prazo são integradas através de uma simples equação que pode ser vista em MEIER (1984). Embora estas mudanças tenham melhorado os modelos tradicionais, eles continuavam tendo problemas semelhantes: dificuldade em calcular a elasticidade preço e grande variação no valor das elasticidades em função do período de tempo considerado. Além disto, o curto período de tempo entre as duas crises do petróleo dificultou ainda mais a determinação dos efeitos dos preços a longo prazo.

Modelos econométricos mais complexos foram desenvolvidos para explicar a complementaridade entre capital e trabalho. Estes modelos são caracterizados 
pela consideração explicita de capital em modelos estruturais (LAPILLONNE, 1990) ou através de capital variável nas funções KLEM (MEIER, 1984).

Em modelos estruturais a demanda de energia é vista como dependendo de três variáveis: estoque de capital (medido em unidades físicas, por exemplo o número de veículos), taxa de uso do estoque de capital (quilômetros rodados por veículo) e eficiência do equipamento (consumo de combustível por quilômetro). Estes modelos são usados principalmente para estudar a demanda de combustíveis em frotas devido a quantidade de veículos ser bem conhecida, como feito por KOURIS (1983b) para os Estados Unidos.

Nos modelos KLEM, baseados em teoria microeconômica, em contraste com os modelos estruturais, a demanda de energia não é considerada separadamente, mas relacionadas a outros fatores de produção como capital, trabalho e matéria prima. Um novo conceito, a elasticidade de substituição, foi introduzido para medir a alteração entre os fatores de produção. Estes modelos têm sido utilizados principalmente em estudos de demanda industrial; SOUZA SANTOS (1986) apud ARAÚJO (1988) faz uma aplicação deste modelo para a indústria brasileira.

Os principais limites dos modelos KLEM são: disponibilidade de dados e falta de robustez, ou seja, pequenas modificações no modelo alteram substancialmente os resultados (LAPILLONNE, 1990).

\section{Modelos técnico-econômicos}

Os modelos técnico-econômicos foram desenvolvidos inicialmente para analisar os efeitos, a longo prazo, de aumento de preços de energia e de políticas de conservação de energia, em países industrializados, sobre a demanda de energia. Embora existam vários modelos técnico-econômicos desenvolvidos e aplicados em vários países (ARAÚJO, 1988), todos apresentam características semelhantes:

- representam detalhadamente os usos-finais (por exemplo: cocção e iluminação no setor residencial);

- calculam, para cada uso final, a demanda de energia em termos de energia útil, utilizando indicadores técnicos, econômicos e sociais. Neste item, os 
equipamentos utilizados por consumidores de energia são considerados explicitamente;

- utilizam cenários para estimar o desenvolvimento dos fatores relacionados a política econômica e energética;

- utilizam modelos para traduzir os cenários em demanda de energia por usosfinais.

Para os modelos técnico-econômicos, a demanda de energia (por exemplo: derivados de petróleo, eletricidade) é resultado da satisfação de uma necessidade energética (energia mecânica ou térmica) por um equipamento (motor, caldeira) o qual é caracterizado pelo tipo de energia que consume e pela eficiência de conversão. A distinção entre energia útil e uso final possibilita avaliar os efeitos da substituição entre energéticos na demanda total, especialmente entre energéticos com diferentes eficiências de conversão no uso final, por exemplo a substituição de combustíveis fósseis por eletricidade, ou ainda a substituição de combustíveis não comerciais por combustíveis comerciais.

Portanto, para conseguir resultados satisfatórios com estes modelos é importante ser preciso nas hipóteses, prevendo, o melhor possível, as mudanças tecnológicas, sociais e econômicas.

Para facilitar o estudo de modelos técnico-econômicos eles podem ser divididos em duas grandes famílias: modelos de decomposição de consumo e modelos de usos finais (ARAÚJO, 1988). 


\section{Modelos de decomposição de consumo}

O objetivo deste método, segundo ARAÚJJ (1988) é "decompor variações no consumo de energia em várias parcelas atribuíveis à variações de diversos fatores, os mais usuais sendo intensidade energética, estrutura econômica e nível de atividade (entretanto, não precisa restringir-se a estes; nada impede que outros sejam adicionados)".

Uma aplicação deste método foi feita por DARMSTADTER (1977) apud LAVERGNE (1990) em um estudo conhecido por Resource for the Future (RFF). O RFF comparava o consumo de energia em diversos países através da identificação de setores econômicos, como agricultura, indústria, comércio, transportes e doméstico, sem necessitar de modelos de comportamento ou hipóteses sobre as funções de produção.

A abordagem proposta por DARMSTADTER (1977) apud LAVERGNE (1990) foi uma das primeiras a tentar explicar a demanda de energia através da desagregação estrutural dos consumidores de energia. Esta característica conduziu aos modelos de usos finais.

\section{Modelos de usos finais}

A primeira geração de modelos de usos finais, segundo LAPILLONNE (1990), ficou também conhecida por modelos contábeis.

Nestes modelos as mudanças na maioria das variáveis são exógenas e definidas dentro de cenários. A principal função do modelo é realizar rapidamente uma série de operações matemáticas. As variáveis socioeconômicas e, especialmente, as energéticas, como substituição e conservação de energia, são especificadas em cenários, os quais têm papel fundamental neste método. Isto exige usuários que conheçam bem as relações entre energia e sociedade, economia e tecnologia.

O mais importante representante dos modelos de usos finais é o Modèle d'Evolution de la Demande d'Énergie (MEDEE) desenvolvido na França pelo Instituto Econômico e Jurídico da Energia (GOLDEMBERG, 1986). O MEDEE, difundido amplamente em vários países como Portugal e Argélia (LAVERGNE, 
1990), foi utilizado também por GOLDEMBERG (1986) na previsão da demanda e investimentos em energia para o ano 2000 no Estado de São Paulo. Outra aplicação do MEDEE, foi feita pela Cesp em 1990, para prever e avaliar a demanda de energia no ano 2000 para o Brasil (SÃO PAULO, 1990).

O método técnico-econômico por usos finais, resumidamente, consiste em desagregar a demanda até o nível de usos finais (por exemplo: cocção, aquecimento de água, iluminação para o setor residencial e calor de processo, força motriz para a indústria). Depois, os setores de uso são desagregados até poder considerá-los como módulos socioeconômicos homogêneos do ponto de vista de comportamento e necessidades (o setor residencial pode ser desagregado em urbano e rural e para cada um pode-se distinguir duas ou mais faixas de renda). Finalmente, são utilizados cenários para levar em conta os fatores não quantificáveis e os fatores dependentes diretamente de opções políticas. Para maior aprofundamento ver GOLDEMBERG (1986) que fornece uma visão detalhada da aplicação do MEDEE para o Estado de São Paulo.

O ponto forte desta abordagem é prover uma detalhada e simples estrutura de demanda por um longo período de tempo; além disto o modelo é simples e não precisa de longas séries temporais de dados. O principal fator limitante dos modelos técnico-econômicos é como contabilizar as evoluções e comportamentos socioeconômicos, uma vez que a sensibilidade das variáveis econômicas é baixa e os preços dos energéticos não são explicitamente considerados. Estes problemas foram reduzidos utilizando modelos econômicos complementares e incluindo os preços dos energéticos no modelo.

\section{Modelos insumo-produto}

Uma forma de melhorar a análise macroeconômica dos modelos de energia é utilizar a representação de economia proposta por LEONTIEF³ , a qual é baseada

${ }^{3}$ Leontief, W. publicou a primeira tabela insumo-produto para a economia norte-americana em 1936. Através da ampla utilização de tabelas insumoproduto este método passou a ser utilizado além da teoria econômica (MEIER, 1984). 
em relações intersetoriais causadas pelo consumo, usualmente com proporções fixas, reproduzidas utilizando coeficientes fixos, conhecidos também por coeficientes técnicos (LAVERGNE, 1990).

O modelo insumo-produto permite determinar o que pode ser produzido e a quantidade de cada produto necessário para atender a demanda. Para isto, 0 princípio utilizado é a inversão da matriz de coeficientes técnicos $\mathbf{A}$. $\mathbf{A}$ matriz $\mathbf{A}$ representa a relação entre o consumo de um setor e o total dos setores.

Em sistemas fechados, se $\mathbf{Y}$ é definido como o vetor de demanda final e $\mathbf{X}$ como o vetor de produção setorial, então o consumo setorial é igual a $\mathbf{A X}$, ou seja, a quantidade de insumos gastos no próprio setor é calculada como o produto da matriz de coeficientes técnicos pelo vetor de produção setorial.

A demanda final pode ser calculada pela equação básica:

$$
Y=X-A X
$$

que invertida, leva a produção total necessária para satisfazer a demanda.

$$
X=(1-A)^{-1} \cdot Y
$$

A matriz $(1-A)^{-1}$ é conhecida por matriz de Leontief.

O modelo insumo-produto, devido sua simplicidade, tem sido utilizado em quase todo o mundo em planejamento energético, basicamente para gerar projeções consistentes de atividades setoriais; um exemplo desta aplicação pode ser visto em GOETTLE et alii (1977) apud ARAÚJO (1988) onde a representação insumoproduto é utilizada para as indústrias norte-americanas. MEIER (1984) também faz uma aplicação do modelo insumo-produto para Portugal a fim de projetar a demanda de energia por setor de consumo. Outra aplicação do modelo insumoproduto é medir a intensidade direta e indireta de energia de setores ou de produtos específicos, isto tem sido feito com freqüência, inclusive no Brasil por GRAÇA; VANIN em 1982 na obtenção de coeficientes de intensidade de energia (ARAÚJO, 1988).

As principais limitações do modelo insumo-produto, segundo MEIER (1984) são a invariação dos coeficientes técnicos, devido a estrutura rígida do modelo que limita o seu uso em estudos a longo prazos e a dificuldade de introduzir o efeito dos preços sem hipóteses adicionais. 


\subsubsection{Modelos de oferta}

Nos modelos de oferta são considerados o fluxo de energia e as tecnologias utilizadas nas fases de extração, transformação, transporte, distribuição e usofinal. Todos combustíveis, setores de consumo, ou ainda, o sistema energético como um todo, é possível modelar.

Os modelos de oferta são mais simples que os de demanda, excluindo-se os modelos setoriais cuja diversidade é decorrente das próprias especializações (ARAÚJO, 1988).

Este tipo de modelo, devido a natureza do sistema de oferta de energia, é possível dividir em dois: modelos setoriais e globais.

\section{Modelos setoriais}

São modelos que consideram apenas um combustível ${ }^{4}$. A evolução do consumo, da demanda e do suprimento é considerada isoladamente do resto do sistema, limitando a visualização ao sistema supridor de energia.

A maioria destes modelos busca a otimização de políticas setoriais, não se excluindo outras questões: dimensionamento de recursos e reservas naturais, produção de energia e finalmente os modelos que apresentam um amplo espectro de decisões a tomar no setor.

Das grandes famílias de modelos setoriais são mostradas as duas mais importantes: as dos setores elétrico e petróleo.

\section{Setor elétrico}

A análise de investimentos no setor elétrico é um assunto estudado a muito tempo, com rica literatura e com ampla aplicação na prática, (ARAÚJO, 1988). Muitos modelos matemáticos são utilizados em empresas de energia elétrica, como exemplo pode-se citar o Wien Automatic System Planning Package (WASP), que

\footnotetext{
${ }^{4}$ Single fuel model
} 
é um modelo de otimização da rede elétrica utilizado em vários países em desenvolvimento, (IAEA, 1982 apud LAVERGNE, 1990). O WASP, em função do custo marginal de expansão do sistema supridor, calcula o investimento requerido para cada tipo de usina (hidroelétrica, térmica a carvão, a óleo combustível e a gás e nuclear) e o combustível a ser consumido.

Outros modelos buscam otimizar diferentes variáveis como: a expansão da capacidade do sistema, onde a rede de transmissão e as usinas são consideradas. O modelo SCELEC (DE VRIES, 1982 apud DIJK; KOK, 1987) desenvolvido e aplicado na Holanda, compara diferentes estratégias de expansão do sistema de potência utilizando como critérios o custo marginal, a segurança do sistema e a composição dos combustíveis, utilizados em geração de energia elétrica, na matriz energética .

Em países, como o Brasil, cujo sistema elétrico é fundamentalmente hidráulico, os fatores hidrológicos devem ser considerados, os efeitos sazonais não podem ser desprezados. MAKAROVA (1966) apud MEIER (1984) mostra um modelo no qual os problemas de localização e sazonalidade são ponderados.

As perdas através das redes de transmissão energia elétrica também são objeto de estudo em modelos desenvolvidos para o setor elétrico. Estes modelos buscam otimizar os parâmetros de resistência e indutância visando reduzir as perdas, um destes modelos é desenvolvido por MEIER (1984) para a American Electric Power.

\section{Setor petróleo}

Os modelos de oferta de petróleo podem ser divididos em três tipos: modelos de exploração e explotação, modelos de operação e planejamento e modelos de mercado de produtores. Os dois primeiros auxiliam na decisão e o terceiro procura entender o comportamento dos produtores e preços internacionais.

A atenção dos modelos de exploração e explotação é o estudo das reservas relacionadas às atividades de exploração e produção de campos petrolíferos.

Os modelos de operação e planejamento são fundamentalmente empresarial, utilizam os resultados dos outros dois tipos de modelo como entrada e podem ser 
distribuídos em três níveis: operacional, tático e estratégico. MEIER (1984) utiliza um modelo de operação e planejamento para, a partir de dados de produção de derivados de petróleo, otimizar a necessidade de petróleo, indicar a produção e os mercados exportadores da África Ocidental ${ }^{5}$. Para isto o modelo utiliza programação linear.

Os modelos de mercado de produtores procuram compreender a dinâmica dos preços internacionais e das atividades de exploração e produção (ARAÚJO, 1988). Modelos de mercado de produtores foram desenvolvidos por PINDYCK (1981) e PAKRAVAN (1981), onde procurou-se incorporar decisões de exploração e produção, assim como a incerteza em vários regimes de competição (monopólio, oligopólio, e livre mercado). Uma grande aplicação deste tipo de modelo é poder extrair inferências sobre o comportamento a longo prazo dos preços e da produção a partir de hipóteses sobre a natureza do mercado e dos recursos.

\section{Modelos globais}

O sistema supridor do setor energético, quando tratado como um todo em um modelo, abrange o fluxo de energia desde as fontes primárias até os processos de transformação, transporte, distribuição e utilização nos diferentes setores de usofinal.

Esta representação evita algumas das limitações de modelos que consideram apenas um combustível.

Os modelos de suprimento de energia, em geral, utilizam métodos de simulação ou otimização, os quais são estruturados em técnicas de programação linear e não linear.

Como exemplos de modelos de oferta pode-se citar: o desenvolvido por KAVRAK (1978), aplicado na Turquia, que busca utilizar a energia de forma mais eficiente com o menor custo; o modelo SELPE, (BOONEKAMP, 1983 apud DIJK; KOK, 1987), que incorpora múltiplos objetivos (minimizar impactos ambientais, custos e

${ }^{5}$ A África Ocidental era uma federação formada por oito países colonizados pela França: Mauritânia, Senegal, Níger, Guiné, Burkina Fasso, Costa do Marfim e Mali. 
esgotamento de reservas); o estudo energético do IIASA (HÄFELE, 1981 apud DIJK; KOK, 1987), que descreve e analisa a demanda e o suprimento de energia na Holanda durante 50 anos, tendo como objetivo único a minimização de custos e o Energy Flow Optimization Model (EFOM), (SEIXAS; MARTINS, s/d), que descreve com detalhes o sistema energético, bem como as respectivas emissões de poluentes atmosféricos através de um módulo ambiental.

Todos os modelos acima citados utilizam como método a otimização.

Como exemplo de modelo de oferta que utilizam outros métodos têm-se: o modelo NIMFEA (Méthode Normative des Impacts Macroéconomiques des Filières Énergétiques Alternatives) desenvolvido pelo Centro de Estudos e Pesquisa em Energia (CEREN) na França (1986) apud LAVERGNE (1990), que prevê alterações no nível de crescimento da produção e suas conseqüências sobre o balanço energético e o mercado de trabalho. O modelo pode ser usado para calcular o consumo intermediário de energia de plantas de produção e transformação, utilizando para isto o método insumo-produto com um grande banco de dados que contém a estrutura de consumo e os investimentos para uma série de usinas. O Energy Flow Model, desenvolvido pela INNOTEC SYSTEMANALYSE (1987), utiliza como método a simulação e foi aplicada para a Comunidade Européia. O modelo descreve todo fluxo de energia de um país ou região e apresenta graficamente os resultados do balanço energético facilitando o entendimento e a interpretação do fluxo e da estrutura de energia da região estudada. Uma aplicação do Energy Flow Model para os países da OLADE também foi feita pela INNOTEC SYSTEMANALYSE (s/d).

\subsubsection{Modelos energia-economia}

Os modelos energia-economia foram desenvolvidos a fim de representar as interfaces entre o setor energético e a economia, incluindo, em alguns casos aspectos ambientais. Eles são construídos na forma de um sistema integrado ou utilizam uma série de modelos acoplados.

O Multi Regional Model of the Economy, Environment, and Energy Demand (MREEED) (LAKSHMANAN, 1983), é um exemplo de modelo energia-economia 
que além de prever e avaliar as conseqüências de políticas regionais e nacionais sobre a economia e a demanda de energia, também calcula os impactos sobre 0 meio ambiente.

Os modelos energia-economia permitem estudar os efeitos em duas direções: do sistema energético sobre a economia e da economia sobre o setor energético. Os modelos utilizados para estudar os efeitos somente em uma direção, como por exemplo calcular os investimentos, a energia consumida, ou ainda os efeitos sobre o meio ambiente para um dado cenário, são chamados de modelos de impacto.

O termo "modelo de equilíbrio parcial" é utilizado para designar os modelos energia-economia que possuem a demanda de energia como função dos preços de energia e estes, por sua vez, são modelados pelo sistema econômico. Se os preços de energia forem ajustados de forma a zerar o excesso de demanda de energia, o modelo é conhecido por de equilíbrio geral. Neste tipo de modelo, por exemplo, enquanto os consumidores maximizam seu conforto, os produtores, os lucros.

Os modelos energia-economia são, em geral, modelos mais complexos e elaborados, como exemplo pode-se citar o modelo desenvolvido por MYOKEN (1990), que foi elaborado considerando dois países interdependentes economicamente e suas respectivas políticas ambientais. $O$ modelo reconhece explicitamente os aspectos de decisão descentralizadas de cada país.

O Minimum Standard Energy Demand Model (MSEDM), elaborado pelo International Bank for Reconstruction and Development (IBRD) (LAVERGNE, 1990), é um outro exemplo de modelo energia-economia. O MSEDM possui dois módulos: o econômico que converte a projeção de demanda final em fatores de produção por setor, utilizando para isto o método insumo-produto, e o módulo energético que relaciona a produção à forma de energia. Este método é muito superior à simples análise insumoproduto, pois mudanças na demanda final, que não são consideradas por modelos insumo-produto, são estabelecidas exogenamente por economistas através de modelos macroeconômicos. Entretanto, apesar dos acertos externos, o comportamento da economia não é perfeitamente ajustado pelo modelo, limitando assim esta abordagem. 


\subsubsection{Modelos globais}

O início da década de 70 foi caracterizado por uma conscientização dos limites de crescimento econômico, isto é mostrado pela quantidade de estudos globais elaborados. O primeiro modelo global com grande repercussão foi preparado pelo Massachusetts Institute of Technology (MIT), para o Clube de Roma e apresentava o mundo como um sistema, no qual a energia era uma categoria de recursos não renováveis, junto com outras matérias primas.

No final de 1974, após a primeira crise do petróleo, o Clube de Roma publica, através de MESAROVIC; PESTEL (1974) apud ARAÚJO (1988), um segundo modelo global, que inclui um tratamento mais compreensivo da energia. $O$ consumo, a produção e a troca entre energéticos são considerados explicitamente para cada uma das dez regiões estudadas.

Depois destes, outros estudos globais, com destaque em socioeconomia, foram elaborados, dentre os quais é importante citar "A latin-american world model", que é a resposta da Fundação Bariloche ao Clube de Roma e o estudo elaborado por LEONTIEF (1977) apud LAPILLONNE (1990) para as Nações Unidas.

Durante a década de 70 também foram elaborados muitos estudos com ênfase em energia. A energia mostrava-se como um sério obstáculo não só ao crescimento econômico mas também ao desenvolvimento futuro. Estes estudos buscavam identificar e analisar as condições que poderiam produzir, a nível mundial, a ruptura entre o suprimento e a demanda de energia.

Segundo LAVERGNE (1990), o primeiro modelo global com ênfase em energia foi o ETA-MACRO. Elaborado em 1977, é uma extrapolação de um modelo de oferta. Este modelo foi utilizado para interpretar as relações existentes entre a economia e o sistema de suprimento de energia. Ele possui um sistema que descreve o suprimento de energia, desenvolvido por MANNE (1977) apud LAVERGNE (1990) conhecido por Energy Technology Assessment (ETA) acoplado a um bloco macroeconômico, o MACRO, que determina as variáveis econômicas assim como a demanda de energia. A demanda de energia, neste modelo, é considerada superficialmente. 
Outros exemplos de modelos globais encontrados são: o Workshop on Alternative Energy Strategies (WAES), o International Institute for Applied Systems Analysis (IIASA) e o modelo de Mukherjee. Apesar dos resultados serem publicados em diferentes datas, todos foram iniciados entre 1973-75, ou seja, imediatamente após da primeira crise do petróleo.

O WAES (1977) apud LAPILLONNE (1990) teve como objetivo identificar o potencial de ruptura do equilíbrio suprimento-demanda global e conduzir governos à buscarem medidas preventivas. O escopo do projeto consistiu na elaboração de cenários, considerando uma série de variáveis como preço de combustíveis, crescimento econômico, juntamente com a sistematização de estudos nacionais de demanda e suprimento de energia. A heterogeneidade dos modelos utilizados nos estudos de cada país constituiu-se na maior limitação deste estudo.

O estudo do IIASA (1981) apud LAPILLONNE (1990), procurou examinar as condições necessárias à transição de uma economia mundial baseada em petróleo para uma onde fontes alternativas, especialmente nuclear e solar, tivessem uma participação mais representativa. A demanda de energia foi estudada em detalhe pelo MEDEE, o suprimento de energia pelo modelo MESSAGE, e os impactos sobre a economia pelo modelo IMPACT. Um dos méritos deste estudo foi mostrar, através da análise do sistema de suprimento, que, a longo prazo, a energia será produzida por diversas fontes, e não simplesmente através do aumento quantitativo da exploração dos atuais recursos.

O modelo de MUKHERJEE (1981) apud LAVERGNE (1990), foi construído com objetivo de melhorar o estudo energético em países em desenvolvimento. O modelo fornece como resultado cenários que mostram os efeitos de mudanças em variáveis externas (preços de combustíveis, produção de energia primária) sobre a demanda de energia. Estes cenários são úteis na previsão do consumo de energia e no planejamento econômico de países com recursos financeiros e energéticos escassos. Uma extrapolação da estrutura do modelo de Mukherjee é o Simulation of macroeconomic scenarios to access energy demand (SIMA), desenvolvido no IIASA por PARIKH; PARIKH (1979) 
apud LAVERGNE (1990). Uma interessante característica deste modelo é considerar a dívida externa como uma das variáveis. 


\section{MODELO CASCATA: REFERENCIAL TEÓRICO}

Num inventário de modelos integrados com meio ambiente, feito por BROUWER (1987), foram estudados quatorze modelos. Pode-se observar, a partir deste levantamento, que cada modelo enfatiza uma área do conhecimento, isto é, economia, ecologia, demografia, energia ou geografia.

Em outro artigo, elaborado por NIJKAMP; VOLWAHSEN (1990), são apresentados outros modelos de energia, que consideram questões ambientais, aplicados a três estudos de casos. O primeiro analisa o fluxo da contaminação da água provocada por processos energéticos e industriais, o segundo os impactos provocados pelo uso de fontes de energia renováveis (geotérmica, eólica, solar e biomassa) comparando-os aos provocados pelo uso de fontes tradicionais (eletricidade, carvão e petróleo) e o terceiro compara as opções tecnológicas na expansão do sistema de aquecimento de um distrito.

Em todos os modelos vistos, a atenção é focada a uma específica fonte de energia, ou a uma específica tecnologia ou ainda a um específico tipo de impacto. O modelo cascata é uma tentativa de sintetizar as experiências com estas diferentes ferramentas procurando cobrir a maioria dos tópicos de interesse, ou seja, energia, tecnologia, economia e meio ambiente. Este modelo não esgota $e$ nem descarta a utilização dos demais, mas apresenta-se como uma ferramenta que possibilita uma visão macro de todo o sistema energético fornecendo indicadores de áreas a serem aprimoradas.

Para o Brasil, nenhuma aplicação de modelo global que integrasse energia e meio ambiente foi encontrada, até mesmo porque, apesar de algumas tentativas do Ministério das Minas e Energia em realizar um planejamento energético integrado, o planejamento energético nacional é feito pelos setores.

Nos setores pode-se observar a incorporação de variáveis ambientais. Nos dois últimos planos elaborados pela Eletrobrás (BRASIL, 1994), Planos 2010 e 2015 , as intervenções sobre o meio ambiente são internalizadas e planos, programas e projetos ambientais são elaborados visando evitar impasses com a sociedade, 
reduzindo tempo e recursos financeiros despendidos na aprovação e execução dos projetos.

Outros trabalhos encontrados que integram energia e meio ambiente no Brasil através de modelos ${ }^{1}$, estudam um setor, um tipo de impacto ou ainda uma determinada tecnologia.

\subsection{Definição e características do modelo}

O modelo cascata foi desenvolvido pela Europlan ${ }^{2} e$ é usado satisfatoriamente em alguns países membros da Comunidade Européia (EUROPLAN, s/d). O conceito essencial é a introdução explícita de tecnologias energéticas dentro de um balanço energético integrado ${ }^{3}$, e o principal aspecto metodológico é a combinação de tecnologias e fontes de energia dentro de uma cascata de matrizes.

Segundo a classificação de ARAÚJO (1988), o modelo cascata é um modelo de oferta global utilizado no modo simulação ${ }^{4}$, no suporte de decisões a médio e longo prazo.

\subsection{Desenvolvimento do modelo}

Os impactos ambientais do setor energético não dependem apenas das fontes de energia mas também das tecnologias utilizadas nos processos de extração, transporte, conversão, distribuição, consumo e uso final, portanto uma das formas

\footnotetext{
${ }^{1}$ Ver por exemplo CUNHA, 1989.

${ }^{2}$ A Europlan é uma das 50 empresas das Organizações para Promoção da Tecnologia em Energia (OPET) da Comunidade Européia.

${ }^{3}$ Os balanços energéticos integrados contabilizam a seguinte cadeia energética: recursos - produção - transformação - utilização final - energia útil. A energia contida em recursos energéticos é a origem de fluxos energéticos e a energia útil o destino final (BICALHO, 1986).

${ }^{4} \mathrm{O}$ modo simulação pode ser utilizado com diversas finalidades das quais pode-se destacar três: na exploração de situações em torno de uma solução encontrada no modo otimização, na exploração de variantes de uma estrutura
} 
de analisar os impactos é utilizar o balanço energético e considerar as tecnologias utilizadas em cada fase do processo de conversão de energia.

Um formato encontrado de relacionar tecnologia utilizada com balanço energético consiste numa série de matrizes onde as colunas descrevem as tecnologias e as linhas as fontes de energia (EUROPLAN, s/d).

\subsubsection{Balanço energético na forma de cascata de matrizes}

O primeiro passo na construção do modelo cascata consiste em definir as matrizes com as tecnologias utilizadas, relacionando-as com as fontes de energia na forma de uma cascata, figura 2.1. O resultado desta cascata de matrizes representa um completo balanço energético incluindo as tecnologias utilizadas no processo de extração, conversão e uso de energia.

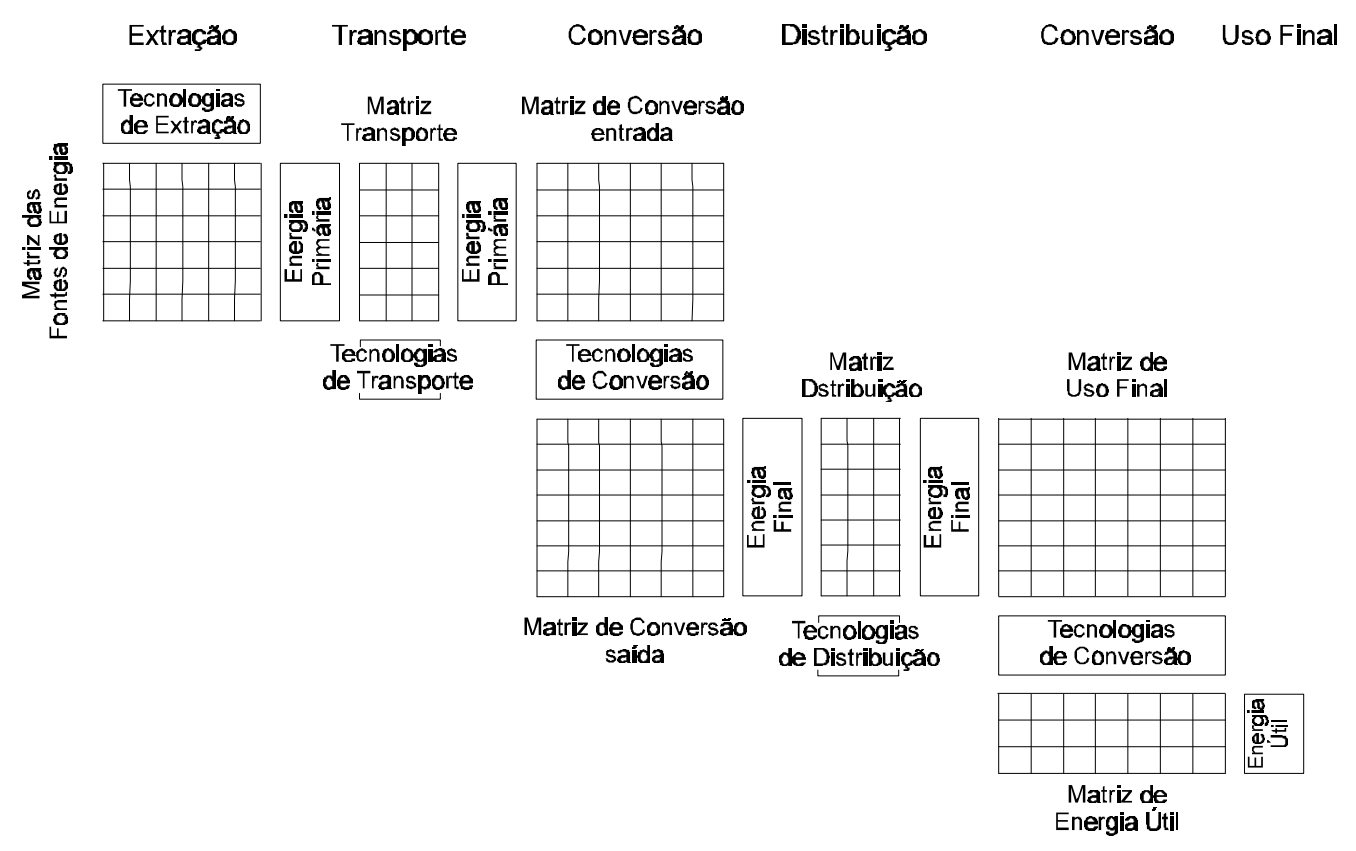

Fig. 2.1 Balanço energético na forma de uma cascata de matrizes de tecnologias Fonte: NIJKAMP; VOLWAHSEN (1990).

de oferta qualquer e na construção de cenários de oferta levando em conta as políticas de vários decisores (ARAÚJO, 1988). 
Matrizes individuais são fundamentais para uma consistente avaliação dos impactos, pois eles são diferentes para cada combinação entre fonte de energia e tecnologia utilizada. Uma avaliação feita somente para fontes de energia ou tecnologias não conduz a um resultado satisfatório.

\subsubsection{Descrição das matrizes}

Em geral, uma série de sete matrizes é suficiente para representar o balanço completo de energia:

A. Matriz de tecnologias de extração: contém a energia importada e as mais importantes tecnologias de extração, por exemplo: bombeamento de petróleo e gás em continente, bombeamento de petróleo e gás em plataforma marítima, mineração profunda, mineração a céu aberto, corte de cana-de-açúcar, corte de lenha, etc.

B. Matriz de tecnologias de transporte: descreve os meios de transporte do local da extração ao de conversão, com a finalidade de avaliar os impactos ambientais de tecnologias de transporte de energia, que podem ser: rodovia, hidrovia, ferrovia, dutovia e outros.

C e D. Matrizes de conversão de energia - entrada e saída: consideram tecnologias de conversão de energia, que transformam energia primária (entrada) em energia secundária (saída), exemplos: usinas termelétricas, usinas nucleares, usinas hidroelétricas, refinarias, usinas eólicas, etc. Incluem também as perdas no processo.

E. Matriz de tecnologias de distribuição: contém os meios pelos quais são feitas a distribuição de energia, as perdas e o consumo de energia próprio.

F. Matriz de conversão de energia para uso final - entrada: incluem as tecnologias de uso final como: fornos industriais, sistemas elétricos industriais, 
motores de automóveis, motores de caminhões, motores de trens, equipamentos elétricos residenciais e outros.

G. Matriz de energia útil: descrevem a forma final da energia utilizada: força, iluminação, calor, perdas, etc.

\subsubsection{Coeficientes de impacto}

A avaliação quantitativa de impactos é feita por intermédio de coeficientes. Os impactos ambientais são calculados utilizando fatores de emissão específicos para cada processo. O método é simples e será mostrado através de um exemplo.

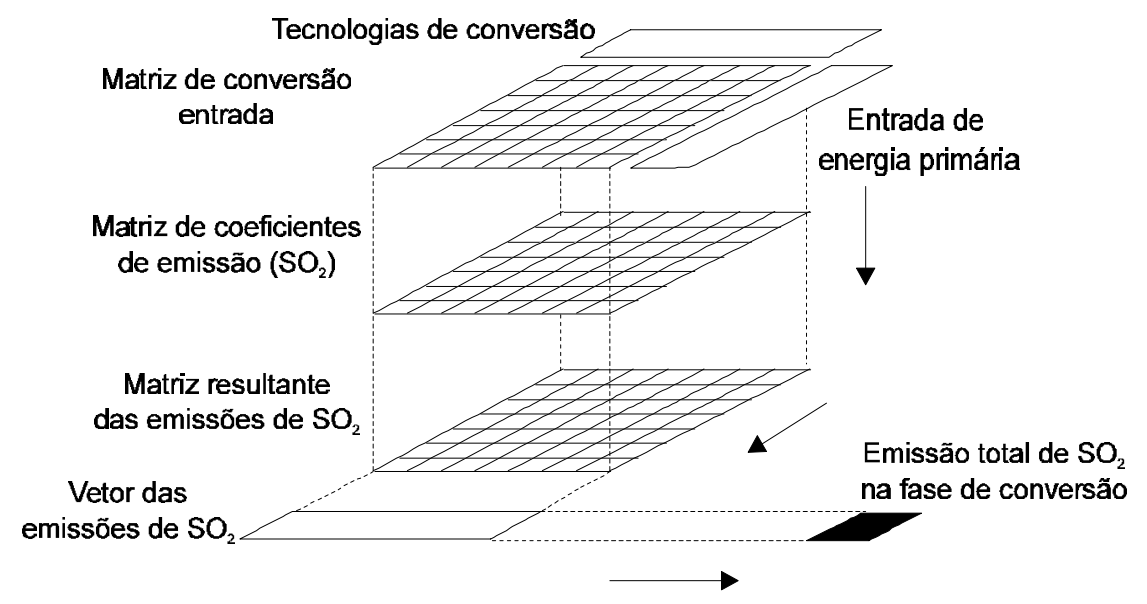

Fig. 2.2 Emissões total de $\mathrm{SO}_{2}$ para uma das matrizes.

Fonte: NIJKAMP; VOLWAHSEN (1990).

A figura 2.2 mostra a matriz de conversão sendo multiplicada pela matriz de coeficientes de emissão de dióxido de enxofre; o resultado encontrado é o total das emissões nesta fase do balanço energético, área sombreada da figura 2.3.

As emissões de $\mathrm{NOx}, \mathrm{CO}, \mathrm{CO}_{2}$ e outros impactos ambientais como poluição da água e do solo são calculados utilizando uma matriz de coeficientes para cada tipo de impacto, em cada degrau da cascata. Os coeficientes de impacto contidos nas matrizes são obtidos, em geral, de estudos de órgãos governamentais nacionais ou internacionais. 
O resultado deste procedimento é uma série de matrizes de impacto ambiental, parte inferior da figura 2.3, que pode ser resumida em um vetor de impacto total ou avaliada separadamente a fim de identificar o processo mais poluente (NIJKAMP; VOLWAHSEN, 1990).

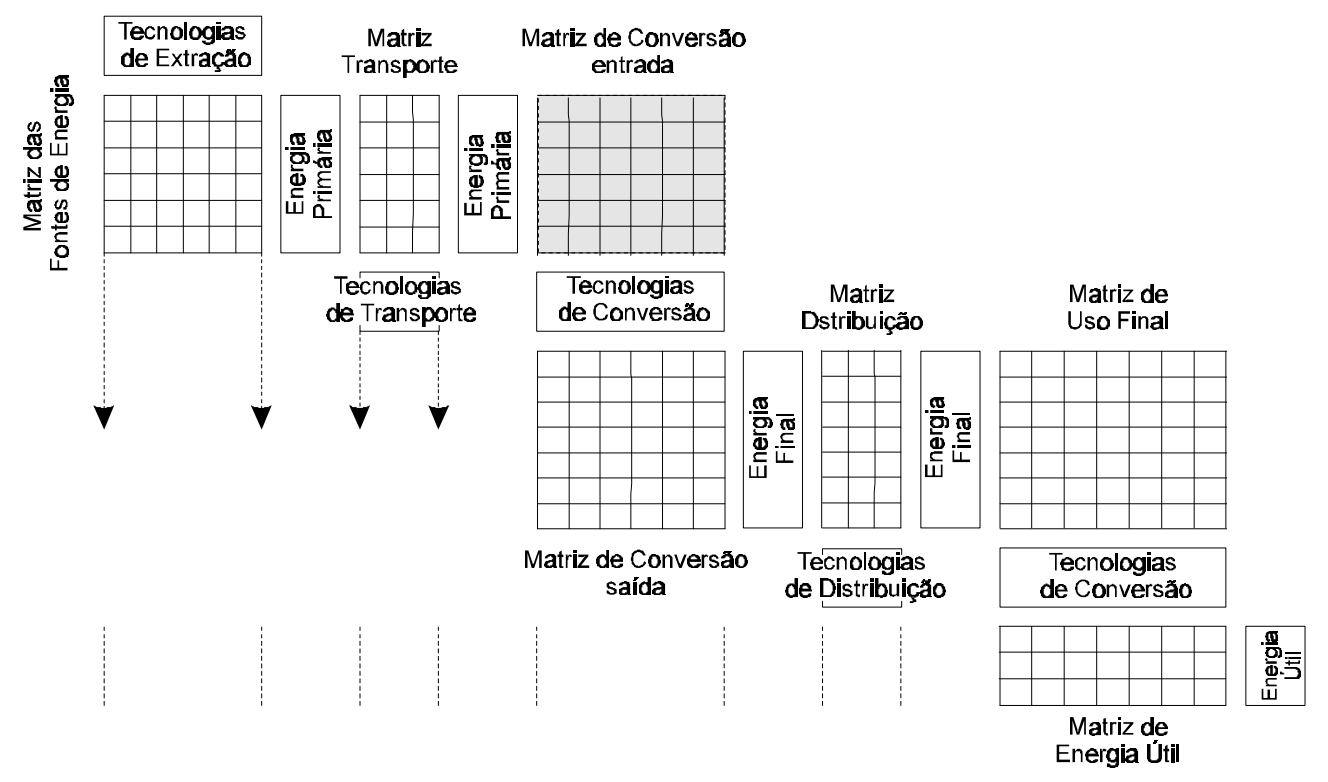

Impactos sobre o meio ambiente por energético e por tipo de tecnologia

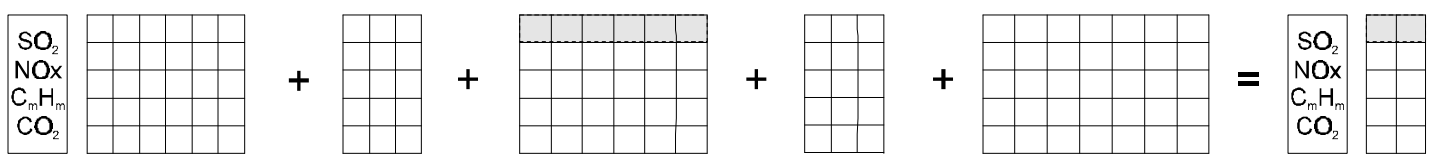

Fig. 2.3 Balanço ambiental calculado a partir da cascata de matrizes do modelo Fonte: NIJKAMP; VOLWAHSEN (1990).

\section{3 llustração do modelo}

Conceitualmente, o modelo cascata é um instrumento simples. Para se ter uma idéia da aplicação do modelo, foi reproduzido o balanço energético elaborado pela EUROPLAN (s/d) para a República Federal Alemã, ano base 1985. A análise dos impactos inicia-se com o balanço energético no formato de cascata, parte superior da figura 2.4.

Cada uma das tecnologias listadas nas matrizes possuem diferentes impactos ambientais, isto é, diferentes fatores de emissão foram considerados para cada uma delas. Os fatores de emissão são armazenados em uma matriz paralela. 
A simples multiplicação das matrizes de impacto com a cascata de tecnologias fornece o resultado, mostrado na parte inferior da figura 2.4, que representa o balanço ambiental de cada fase do processo, permitindo uma análise precisa dos impactos provocados.

\subsection{Aplicações do modelo}

Como já visto, o modelo cascata, através dos balanços energético e ambiental que fornece, é útil na avaliação de impactos ambientais e econômicos sobre o sistema energético.

Conjugado a modelos de previsão de consumo e a legislação, permite simular alterações no sistema energético, através da técnica de cenários, fornecendo como resultado a alteração quantitativa dos impactos.

Introduzidas as alterações esperadas no sistema energético: aumento na demanda de energia, redução dos coeficientes de emissão - resultado dos investimentos destinados à medidas de controle de emissões ou à evolução da legislação - o modelo calcula o total líquido do efeito, assumindo todas as mudanças, e permite elaborar gráficos com a expectativa dos níveis de emissão até o ano 2010, como, por exemplo, o da figura 2.5.

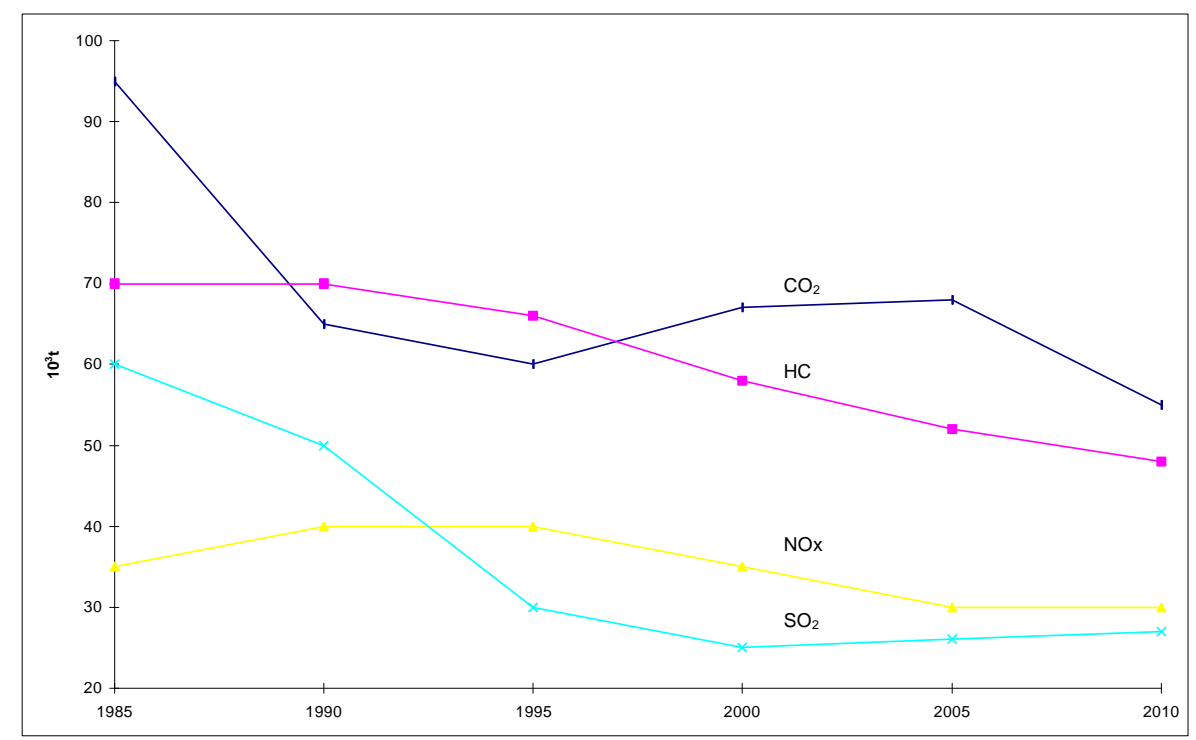

Fig. 2.5 Modelo cascata utilizado na previsão de impactos ambientais Fonte: EUROPLAN (s/d). 
Além disto, o modelo cascata, como uma ferramenta analítica, é útil também ao planejador e ao decisor:

- na destinação de investimentos em novos empreendimentos, melhorando a eficiência na utilização de energéticos;

- em audiências públicas sobre sistemas energéticos e meio ambiente, substituindo argumentos ideológicos por argumentos sólidos;

- na condução de discussões sobre um específico poluente em direção a uma discussão ampla sobre impactos ambientais em todos os estágios do processo de conversão de energia;

- na demonstração que não há conflitos entre conservação de energia, crescimento econômico e proteção ambiental.

\subsection{Limites do modelo}

"Não há concepção ótima de modelo para todos os propósitos" (FERREIRA, 1989).

O modelo cascata é uma representação contábil de uma realidade complexa e dinâmica; em função disto, a sua elaboração acarreta uma inevitável perda de informações introduzindo certos limites à sua utilização como instrumento de análise e planejamento. Para que as informações nele contidas sejam utilizadas adequadamente é importante conhecer estes limites.

Por mais detalhado que seja, o modelo cascata não apresenta todas as informações necessárias ao cálculo da matriz energética e ambiental, portanto torna-se indispensável utilizar outros modelos ${ }^{5}$ e submodelos que fornecerão dados de entrada, projeções e variáveis contextuais. Estes modelos devem levar em consideração variáveis de decisão ou contexto (demografia, macroeconomia, investimentos, política de preços, tecnologia, legislação), uma vez que o modelo cascata não as considera explicitamente. Portanto, os critérios utilizados na

${ }^{5}$ Estes modelos podem ser, principalmente, os de demanda, de oferta setorial ou de oferta global no modo otimização. 
definição destas variáveis é fundamental sob o risco de comprometer todo o resultado e conseqüentemente a análise.

As variáveis de controle (uso de energia, poluição, custos e intensidade energética) resultantes do modelo cascata podem ser utilizadas para avaliar as diferentes políticas que definiram as variáveis de decisão.

A disponibilidade de dados é outro fator, ainda que externo, de limitação do modelo. Alguns setores carecem de dados sistematizados, ainda mais quando se considera a tecnologia utilizada no processo. A dificuldade de obtenção de informações, gera a necessidade de estimativas, aproximações que podem comprometer a confiabilidade dos dados, caso não se tome o cuidado de explicitálas.

Certamente há outros limites que apenas com a ampla utilização do modelo serão observados. 


\section{ESTUDO DE CASO: CANA-DE-AÇÚCAR E SEUS PRODUTOS}

O modelo cascata, como já visto no capítulo anterior, é um balanço energético que foi desenvolvido considerando todos os energéticos e seus impactos ambientais. Neste estudo de caso apenas uma fonte de energia e o seu impacto mais significativo são estudados: a cana-de-açúcar e as emissões atmosféricas provenientes de todo processo energético. Outras fontes de energia e impactos ambientais não fazem parte deste trabalho devido a quantidade e a disponibilidade de informações necessárias para alimentar o modelo.

O objetivo deste estudo de caso é ilustrar o modelo, observar sua aplicabilidade e discutir seus resultados.

A cana-de-açúcar é a fonte de energia estudada devido:

- encontrar-se em desenvolvimento tecnológico,

- apresentar problemas ambientais controversos, e

- ter dados e informações disponíveis.

Isto permitiu obter matrizes mais desagregadas com índices mais confiáveis.

O impacto ambiental mais significativo, e por isto escolhido para ser estudado, da produção e consumo da cana-de-açúcar e seus derivados é a poluição atmosférica produzida pelas emissões provenientes das diversas fases do processo energético. Outros impactos como: disposição de resíduos líquidos e socioeconômicos também podem ser considerados pelo modelo, mas não o foram devido a quantidade de informações necessárias para obter resultados consistentes.

A figura 3.1 ilustra como as matrizes, síntese do método, expressam o modelo nas diversas etapas do processo energético: produção, extração, transporte, conversão, armazenagem, distribuição, consumo e uso final.

Como pode ser visto na figura 3.1, a estrutura geral do modelo é composta de sete partes:

- produção

- extração

- transporte 
Balanço Energético para o Estado de São Paulo

ano base 1991

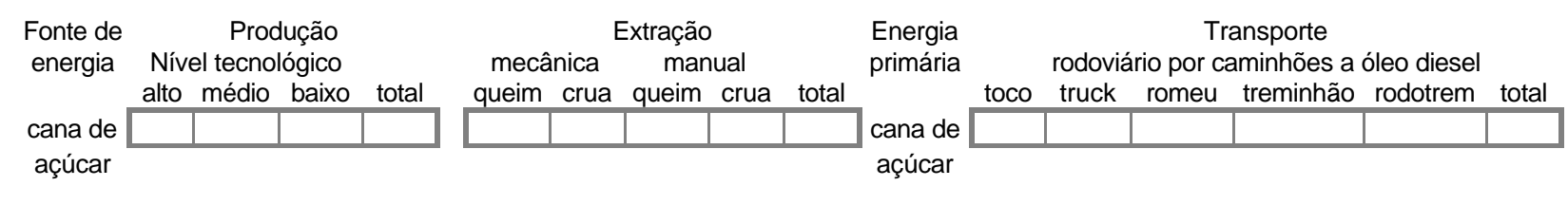
Conversão Energia Tran. Arm. Nível tecnológico secund. rod. prim. alto médio baixo total

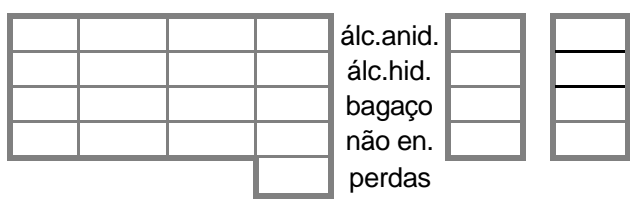

$10^{3} \mathrm{GJ}$

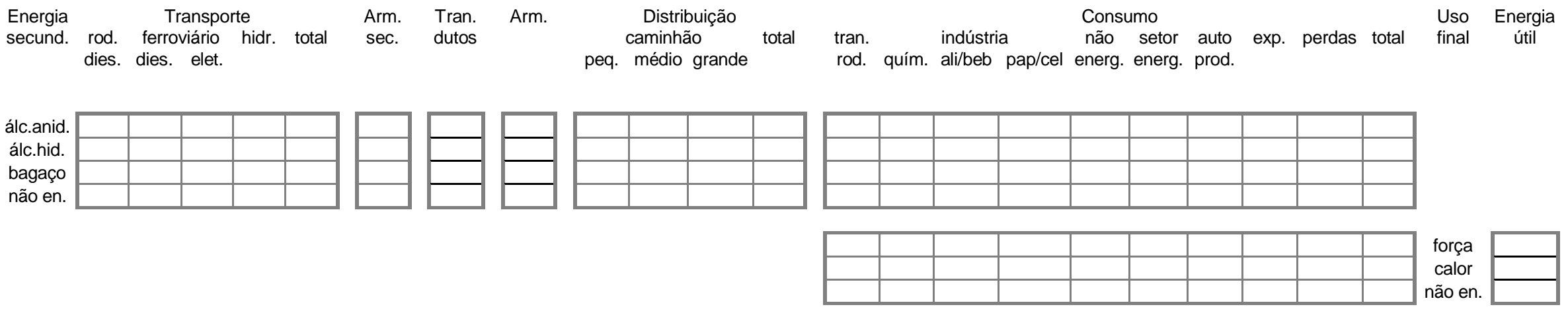

Fig. 3.1 Modelo cascata para cana-de-açúcar e seus produtos 
- conversão

- distribuição

- consumo

- uso final

Cada parte reproduz uma etapa do processo energético e é representada por uma ou mais matrizes. As informações necessárias à elaboração das matrizes e a descrição de cada fase do processo é feita a seguir. É importante lembrar que algumas informações não estavam disponíveis para a área de estudo. Onde isto ocorreu foram utilizados dados parciais de uma empresa, cooperativa ou região, e estes extrapolados criteriosamente para a região estudada, o Estado de São Paulo.

\subsection{Produção}

A fase de produção inicia com o preparo do solo, quando necessário. O preparo do solo é necessário para renovar o canavial; isto ocorre após a queda de produtividade agrícola a níveis que inviabilize economicamente a safra. A cultura é substituída, geralmente, após o quarto corte.

O preparo do solo consiste em destruir as soqueiras ${ }^{1}$, arar o solo, nivelar e destorroar a superfície.

Concluído o preparo do solo é realizado o plantio da cana-de-açúcar. A principal operação do plantio é a sulcação que consiste na abertura de sulcos onde são colocados adubo, inseticidas e a muda da cana.

Outras operações da fase de produção estão relacionadas com a manutenção da cultura: adubação, irrigação, manejo de plantas daninhas, controle de pragas e doenças (BRASIL, 1986).

Esta fase termina com a maturação da cana, isto é, o momento em que o canavial esta pronto para a colheita.

${ }^{1}$ Soqueira ou cana soca é a planta resultante da rebrota do corte feito por ocasião da colheita. 
Neste estudo, devido as diferenças de procedimentos e equipamentos utilizados, que não permitem considerar cada unidade produtiva, as usinas e destilarias foram reunidas, a partir do seu rendimento agrícola, em níveis tecnológicos.

A divisão das unidades agrícolas em níveis tecnológicos é feita no anexo $\mathrm{A}$, e mostrada na tabela 3.1, com base na análise estatística da distribuição dos rendimentos agrícolas de cada unidade.

TABELA 3.1 Distribuição de unidades agrícolas por nível tecnológico

\begin{tabular}{lccc}
\hline Nível tecnológico & $\begin{array}{c}\text { Rendimento agrícola } \\
{[\mathrm{tC} / \mathrm{ha}]}\end{array}$ & $\begin{array}{c}\text { Quantidade } \\
\text { de usinas }\end{array}$ & $\%$ \\
\hline Baixo & até 74,9 & 33 & 28,21 \\
Médio & de 75,0 até 89,9 & 66 & 56,41 \\
Alto & acima de 90,0 & 18 & 15,38 \\
\hline
\end{tabular}

Comparando os valores obtidos com uma pesquisa feita pela COPERSUCAR (1989b) junto æ̀ suas cooperadas, observa-se que o rendimento médio de 81,77 tC/ha, calculado, no anexo A, para o Estado de São Paulo na safra 1991/92, é próximo ao das usinas cooperadas, $77,1 \mathrm{tC} / \mathrm{ha}$.

As faixas obtidas pela análise estatística também incorporam os valores da tabela 3.2 fornecidos por SANTAELLA (1992).

TABELA 3.2 Produtividade agrícola das usinas cooperadas àCopersucar.

\begin{tabular}{lc}
\hline Nível tecnológico & $\begin{array}{c}\text { Produtividade agrícola } \\
{[\mathrm{tC} / \mathrm{ha}]}\end{array}$ \\
\hline Baixo & 65 \\
Médio & 80 \\
Alto & 90 \\
\hline
\end{tabular}

Fonte: SANTAELLA (1992).

A única fonte de emissão nesta fase são os veículos utilizados em operações agrícolas. As emissões são calculadas para dois cenários, os mesmos propostos 
por MACEDO; NOGUEIRA (1985) no artigo "Balanço de energia na produção de cana-de-açúcar e álcool nas usinas cooperadas", e descritos abaixo. Os valores negativos de emissão de $\mathrm{CO}_{2}$ são devido a absorção que ocorre durante o crescimento da planta. Os coeficientes de impacto são calculados no anexo $\mathrm{C} \mathrm{e}$ mostrados na tabela 3.3.

TABELA 3.3 Coeficientes de emissão para a fase agrícola

\begin{tabular}{cccccccc}
\hline Cenário & \multicolumn{7}{c}{ Gases de escapamento [t/10 $\left.{ }^{3} \mathrm{GJ}\right]$} \\
& $\mathrm{CO}$ & $\mathrm{HC}$ & $\mathrm{NOx}$ & $\mathrm{SOx}$ & $\mathrm{MP}$ & $\mathrm{HCHO}$ & $\mathrm{CO}_{2}$ \\
\hline 1 & 0,0018 & 0,0009 & 0,0050 & 0,0005 & 0,0007 & 0,0002 & $-411,7$ \\
2 & 0,0010 & 0,0005 & 0,0027 & 0,0003 & 0,0004 & 0,0001 & $-411,8$ \\
\hline
\end{tabular}

Nota: Cenário 1: valores médios de consumo de energia, insumos e investimentos.

Cenário 2: melhores valores praticados, valores mínimos de consumo e com uso da melhor tecnologia existente e praticada no Estado de São Paulo.

Os custos da fase de produção, tabela 3.4, são calculados utilizando preços e parâmetros da "Estrutura de custo da cana-de-açúcar de fornecedores e usinas" elaborada pela Copersucar para o Estado de São Paulo, safra de 1991/92 (MARQUES, 1994), e parâmetros do "Balanço de energia na produção de canade-açúcar e álcool nas usinas cooperadas" preparado por MACEDO; NOGUEIRA (1985).

No cálculo do custo de produção de cana-de-açúcar, apenas os preços dos insumos energéticos são considerados. Os custos de mão-de-obra, máquinas, despesas administrativas, impostos e taxas não são computados devido a falta de informações que permitam considerá-los em todas as fases do processo.

Os coeficientes de impacto que compõe o modelo cascata estão em unidades que permitam multiplicá-los aos valores do balanço. A unidade adequada para os custos é US $\$ 110^{3} \mathrm{GJ}$. Os valores obtidos em US $\$ / \mathrm{tC}$ são convertidos utilizando a tabela I.4, do apêndice I. 
A quantidade de energia consumida na produção da cana-de-açúcar é calculada a partir do artigo elaborado por MACEDO; NOGUEIRA (1985), "Balanço de energia na produção de cana-de-açúcar e álcool nas usinas cooperadas" e mostrada na tabela 3.5.

TABELA 3.4 Custo de produção de cana-de-açúcar, para o Estado de São Paulo, safra 1991/92

\begin{tabular}{|c|c|c|c|c|c|c|c|}
\hline \multirow[t]{3}{*}{ Insumos } & \multicolumn{3}{|c|}{ Parâmetros [uc/ha] } & \multirow{3}{*}{$\begin{array}{c}\text { Preço }^{(1)} \\
{[\mathrm{US} \$ / \mathrm{uc}]}\end{array}$} & \multicolumn{3}{|c|}{ Custos [US\$/ha] } \\
\hline & \multirow{2}{*}{ Copersucar $^{(1)}$} & \multicolumn{2}{|c|}{ MACEDO;NOGUEIRA ${ }^{(2)}$} & & \multirow[t]{2}{*}{ Copersucar ${ }^{(1)}$} & \multicolumn{2}{|c|}{ MACEDO;NOGUEIRA $A^{(2)}$} \\
\hline & & Cenário 1 & Cenário 2 & & & Cenário 1 & Cenário 2 \\
\hline \multicolumn{8}{|l|}{ Cana Planta } \\
\hline Calcário [t] & 1,8659 & 0,33 & 0,33 & 5,34 & 9,96 & 1,76 & 1,76 \\
\hline Fertilizantes [t] & 0,0414 & 0,12 & 0,08 & 228,41 & 9,46 & 27,41 & 18,27 \\
\hline Herbicidas [kg] & 0,9812 & 0,16 & 0,2 & 10,83 & 10,63 & 1,73 & 2,17 \\
\hline Inseticidas [kg] & 0,2602 & 0,14 & 0,1 & 0,39 & 0,10 & 0,05 & 0,04 \\
\hline Combustível [l] & 19,21 & 23,4 & 9,1 & 0,21 & 4,03 & 4,91 & 1,91 \\
\hline \multicolumn{8}{|l|}{ Cana soca } \\
\hline Fertilizantes [t] & 0,3283 & 0,5 & 0,2 & 234,34 & 76,93 & 117,17 & 46,87 \\
\hline Herbicidas [kg] & 3,0121 & 0,64 & 0,8 & 8,83 & 26,60 & 5,65 & 7,06 \\
\hline Inseticidas [kg] & 0,6943 & 0,4 & 0,4 & 0,39 & 0,27 & 0,16 & 0,16 \\
\hline Combustível [l] & 9,22 & 7,8 & 7,8 & 0,21 & 1,94 & 1,64 & 1,64 \\
\hline Produt. [tC/ha] & & & & & 76,84 & 65 & 65 \\
\hline Total [US\$/ha] & & & & & 139,92 & 160,49 & 79,88 \\
\hline [US\$/tC] & & & & & 1,82 & 2,47 & 1,23 \\
\hline [US $\left.\$ / 10^{3} \mathrm{GJ}\right]$ & & & & & 474,32 & 643,15 & 320,10 \\
\hline
\end{tabular}

Fonte: (1) MARQUES (1994).

(2) MACEDO; NOGUEIRA (1985).

Nota: Cenário 1: valores médios de consumo de energia, insumos e investimentos.

Cenário 2: melhores valores praticados, valores mínimos de consumo e com uso da melhor tecnologia existente e praticada no Estado de São Paulo.

No artigo são analisadas duas situações: a primeira, cenário 1, baseada nas médias de consumo de energia, insumos e investimentos, e a outra, cenário 2 , nos 
melhores valores praticados, valores mínimos de consumo, com o uso da melhor tecnologia existente e praticada no Estado de São Paulo.

MACEDO; NOGUEIRA (1985) dividem os dados em três níveis procurando detalhar a análise energética. No primeiro são considerados os insumos energéticos diretos, no segundo acrescenta-se a energia necessária à produção de outros insumos para a lavoura ou processo industrial e no terceiro a energia necessária para a produção, manutenção de equipamentos e instalações e mãode-obra.

Neste estudo, o terceiro nível não é considerado uma vez que a quantidade de energia necessária para a produção, manutenção de equipamentos e instalações e mão-de-obra não faz parte da análise em outras fases do balanço energético devido a falta de informações. O consumo de energia neste nível varia de 5 a 15\% do total.

TABELA 3.5 Consumo de energia na produção de cana-de-açúcar

\begin{tabular}{lcccc}
\hline Insumo & \multicolumn{2}{c}{ Cenário 1 } & \multicolumn{2}{c}{ Cenário 2 } \\
& $\mathrm{kcal} / \mathrm{tC}$ & $\mathrm{GJ} / 10^{3} \mathrm{GJ}^{(1)}$ & $\mathrm{kcal} / \mathrm{tC}$ & $\mathrm{GJ} / 10^{3} \mathrm{GJ}^{(1)}$ \\
\hline Combustível $^{(2)}$ & 5530 & 6,0 & 2990 & 3,3 \\
Fertilizantes & 16550 & 18,0 & 15480 & 16,9 \\
Calcário & 1620 & 1,8 & 1620 & 1,8 \\
Herbicidas & 2690 & 2,9 & 3490 & 3,8 \\
Inseticidas & 190 & 0,2 & 190 & 0,2 \\
Mudas & 1940 & 2,1 & 1730 & 1,9 \\
\hline Total & 28.520 & 31,0 & 25.500 & 27,9 \\
\hline
\end{tabular}

Fonte: MACEDO; NOGUEIRA (1985).

Nota: (1) Valores convertidos a partir da coluna correspondente.

(2) O valor energético do óleo diesel utilizado por MACEDO; NOGUEIRA (1985), $11.414 \mathrm{kcal} / \mathrm{ld}$, considera o consumo energético associado ao combustível (produção, transporte, processamento), neste caso óleo diesel.

\subsection{Extração}

A fase de extração, para a cana-de-açúcar chamada também de colheita, vai do planejamento do corte até o carregamento em caminhões para o transporte até as unidades industriais. 
A colheita inicia com o planejamento do corte que consiste em determinar o ponto de maturação da cana-de-açúcar. Definida a área e a data de corte, o canavial é queimado, em geral, na madrugada anterior ao corte. A queima propicia um rendimento maior no corte devido a eliminação de folhas e palhas. Apenas uma pequena fração de cana é colhida crua (sem queimar) para ser utilizada como muda na renovação do canavial.

A extração, em grande parte, é manual, realizado por cortadores munidos de facões ou podões. Primeiro é feito o corte rente ao solo e em seguida corta-se a parte superior para eliminação dos ponteiros. Os colmos cortados são dispostos em montes para serem carregados posteriormente.

O carregamento é realizado por carregadores mecânicos, que apanham o monte de cana e colocam sobre as carrocerias dos veículos, os quais fazem o transporte até as unidades industriais.

A colheita mecanizada encontra-se em fase de implantação definitiva; a cada ano aumenta a quantidade de cana colhida desta forma. Basicamente, as colhedoras são máquinas que cortam, despontam e descarregam a cana sobre o terreno ou diretamente sobre os caminhões (BRASIL, 1986).

Segundo KOLLER (1993), quatro formas de colheita são as mais praticadas no Estado de São Paulo:

- Colheita manual com queimada: Oitenta e três por cento (83\%) da cana-deaçúcar colhida por cooperadas da Copersucar são extraídas desta forma. Cada trabalhador rural colhe de 9 a $10 \mathrm{tC} / \mathrm{dia}$.

- Colheita mecanizada com queimada: Nas cooperadas da Copersucar, $15 \%$ de cana-de-açúcar são colhidas por máquinas agrícolas após a queimada. Cada máquina colhe entre 400 e 450 tC/dia.

- Colheita manual sem queimada: Aproximadamente, $2 \%{ }^{2}$ de cana-de-açúcar, das cooperadas da Copersucar, são colhidas por trabalhadores sem queimada. Isto ocorre, em grande parte, devido a necessidade de renovação da área

${ }^{2}$ Com 1 ha de muda são produzidos de 7 a 10 ha de planta comercial. Numa área de 100 ha, cerca de 15 ha são renovados por ano. Utilizando o valor de 
plantada, cerca de $15 \%$ anualmente. O rendimento da colheita manual sem queimada é baixo, cada trabalhador colhe, em média, 3 tC/dia.

- Colheita mecanizada sem queimada: A quantidade de cana-de-açúcar colhida sem queimar por máquinas agrícolas é insignificante pois as máquinas que realizam esta operação encontram-se em fase de desenvolvimento.

Durante a colheita ocorrem emissões de poluentes provenientes de duas fontes. Parte das emissões é devido a queima do canavial. Os coeficientes de emissão de queima de cana-de-açúcar no campo são calculados no item C.2.2 do anexo C. Os tratores que auxiliam na colheita de cana-de-açúcar são a segunda fonte de emissão de poluentes. Os coeficientes de emissão de tratores são obtidos a partir dos fatores de emissão da Environmental Protection Agency (EPA) e calculados utilizando as relações mostradas no item C.1.1 do anexo C.

$\mathrm{Na}$ colheita os coeficientes de emissão são iguais para os dois cenários propostos por MACEDO; NOGUEIRA (1985). Os coeficientes diferem em função da forma de extração da cana-de-açúcar: com ou sem queima, manual ou mecanizada. Os valores obtidos são mostrados na tabela 3.6.

TABELA 3.6 Coeficientes de emissão para extração de cana-de-açúcar no campo

\begin{tabular}{|c|c|c|c|c|}
\hline \multirow{3}{*}{$\begin{array}{l}\text { Gases } \\
\text { emitidos } \\
{\left[\mathrm{t} / 10^{3} \mathrm{GJ}\right]}\end{array}$} & \multicolumn{4}{|c|}{ Forma de colheita } \\
\hline & \multicolumn{2}{|c|}{ manual } & \multicolumn{2}{|c|}{ mecanizada } \\
\hline & com queimada & sem queimada & com queimada & sem queimada \\
\hline $\mathrm{CO}$ & 11,0007 & 0,0007 & 11,0036 & 0,0036 \\
\hline $\mathrm{HC}$ & 2,0004 & 0,0004 & 2,0018 & 0,0018 \\
\hline MP & 0,9003 & 0,0003 & 0,9014 & 0,0014 \\
\hline NOx & 0,0021 & 0,0021 & 0,0101 & 0,0101 \\
\hline SOx & 0,0002 & 0,0002 & 0,0009 & 0,0009 \\
\hline $\mathrm{HCHO}$ & 0,0001 & 0,0001 & 0,0004 & 0,0004 \\
\hline $\mathrm{CO}_{2}$ & 6,8 & 0,1 & 7,4 & 0,7 \\
\hline
\end{tabular}

A tabela 3.7 mostra a quantidade de energia consumida, calculada a partir de relações obtidas no anexo $B$, e o custo do insumo utilizado. $O$ consumo de energia 
durante a colheita é obtido no "Balanço de energia na produção de cana-deaçúcar e álcool nas usinas cooperadas", MACEDO; NOGUEIRA (1985).

Os custos relativos àcolheita variam em função do processo utilizado; em ambos o carregamento é mecanizado. Mantendo a uniformidade do estudo não são considerados os custos relativos àmão-de-obra e manutenção de equipamentos. São considerados apenas os custos dos insumos energéticos.

TABELA 3.7 Custo e consumo de energia em colheita de cana-de-açúcar

\begin{tabular}{lccccc}
\hline $\begin{array}{c}\text { Forma de } \\
\text { colheita }\end{array}$ & \multicolumn{2}{c}{ Consumo de óleo diesel } & Preço & \multicolumn{2}{c}{ Custo } \\
{$[\mathrm{ld} / \mathrm{tC}]$} & {$\left[\mathrm{GJ} / 10^{3} \mathrm{GJ}\right]$} & {$[\mathrm{US} \$ / \mathrm{ld}]$} & {$[\mathrm{US} \$ / \mathrm{tC}]$} & {$\left[\mathrm{US} \$ / 10^{3} \mathrm{GJ}\right]$} \\
\hline Manual & 0,20 & 1,89 & 0,21 & 0,04 & 10,94 \\
Mecanizada & 0,96 & 9,07 & 0,21 & 0,20 & 52,51 \\
\hline
\end{tabular}

\subsection{Transporte}

Após o corte, a cana-de-açúcar é carregada em caminhões a óleo diesel e transportada da lavoura até a usina, percorrendo em média, segundo MACEDO; NOGUEIRA (1985), 16 km, trajeto de ida.

Os principais sistemas adotados, segundo KOLLER (1993), são:

- Caminhão pequeno. Conhecidos como toco, são caminhões de 2 eixos com capacidade média de $10 \mathrm{tC}$. Tem autonomia de 3,6 km/ld. As cooperadas da Copersucar possuem em sua frota 9\% deste tipo de veículo.

- Caminhão médio trucado. Caminhão com 3 eixos e capacidade de carregar, em média, 15 tC. Veículo com boa aceitação para distâncias médias, $30 \mathrm{~km}$ (BRASIL, 1986). A frota das cooperadas da Copersucar possui 55\% deste tipo de veículo, que tem autonomia de $2,2 \mathrm{~km} / \mathrm{ld}$.

- Caminhão reboque. Caminhão com 3 eixos mais um ou dois reboques de 2 eixos. É recomendado para grandes distâncias e topografia favorável.

O conjunto com um reboque, conhecido com romeu e julieta, possui uma capacidade média de carga de 28 tC. Tem uma autonomia de 1,7 km/ld e na frota das cooperadas da Copersucar 32\% dos veículos são deste tipo.

muda para cobrir a área de 15 ha renovada. 
Treminhão é o nome dado ao conjunto com dois reboques. A capacidade média de carga é 45 tC por viagem. Este tipo de veículo possui autonomia de 1,2 $\mathrm{km} / \mathrm{ld}$ e representa $4 \%$ da frota das cooperadas da Copersucar.

- Caminhão semi-reboque. Recomendado para grandes distâncias e deslocamentos fora de talhões. O conjunto composto por um cavalo mecânico e uma carreta, na entressafra pode ser usado para transportar outros produtos. $A$ capacidade média é $50 \mathrm{tC}$, e o consumo $1 \mathrm{ld} / \mathrm{km}$. A quantidade deste tipo de veículo nas cooperadas da Copersucar é estatisticamente insignificante.

Cada conjunto acima provoca um impacto sobre o meio ambiente, os coeficientes de emissão de cada um deles são mostrados na tabela 3.8 e calculados no anexo C com base no artigo "Inventário de emissão veicular - metodologia de cálculo" elaborado por MURGEL (1985), e no método para calcular as emissões de $\mathrm{CO}_{2}$ das atividades consumidoras de energia desenvolvido pelo Intergovernmental Panel on Climate Change (IPCC) em conjunto com a Organization for Economic Cooperation and Development (OECD).

TABELA 3.8 Coeficientes de emissão para veículos utilizados em transporte de cana-de-açúcar

\begin{tabular}{lcccccc}
\hline Tipo de veículo & \multicolumn{6}{c}{ Gases de escapamento $\left[\mathrm{t} / 10^{3} \mathrm{GJ}\right]^{*}$} \\
& $\mathrm{CO}$ & $\mathrm{HC}$ & $\mathrm{NOx}$ & $\mathrm{SOx}$ & $\mathrm{MP}$ & $\mathrm{CO}_{2}$ \\
\hline Toco & 0,0148 & 0,0024 & 0,0108 & 0,0050 & 0,0007 & 0,6 \\
Truck & 0,0099 & 0,0016 & 0,0072 & 0,0033 & 0,0005 & 0,7 \\
Romeu e julieta & 0,0053 & 0,0009 & 0,0039 & 0,0018 & 0,0002 & 0,5 \\
Treminhão & 0,0033 & 0,0005 & 0,0024 & 0,0011 & 0,0002 & 0,4 \\
Rodotrem & 0,0030 & 0,0005 & 0,0022 & 0,0010 & 0,0001 & 0,4 \\
\hline
\end{tabular}

Nota: ${ }^{*}$ tonelada de poluente emitido por quantidade de energia transportada (cana-de-açúcar)

Os custos, assim como a quantidade de energia consumida no transporte da cana-de-açúcar foram calculados considerando apenas o insumo energético direto, neste caso óleo diesel. A tabela 3.9 fornece o custo e o consumo de energia, calculados nos anexos D e B. 
TABELA 3.9 Custo e consumo de energia em transporte de cana-de-açúcar da lavoura até a unidade industrial

\begin{tabular}{lcc}
\hline Tipo de veículo & $\begin{array}{c}\text { Custo } \\
{\left[\mathrm{US} \$ / 10^{3} \mathrm{GJ}\right]}\end{array}$ & $\begin{array}{c}\text { Energia consumida } \\
{\left[\mathrm{GJ} / 10^{3} \mathrm{GJC}\right]}\end{array}$ \\
\hline Toco & 48,62 & 8,4 \\
Truck & 53,04 & 9,2 \\
Romeu e julieta & 36,77 & 6,4 \\
Treminhão & 32,42 & 5,6 \\
Rodotrem & 35,01 & 6,0 \\
\hline
\end{tabular}

Nota: " quantidade de energia consumida (óleo diesel) por quantidade de energia transportada (cana-de-açúcar)

\subsection{Conversão}

Após a recepção da cana-de-açúcar em unidades industriais começa o processo de conversão em açúcar e/ou álcool. A figura 3.2 mostra as principais etapas do processo.

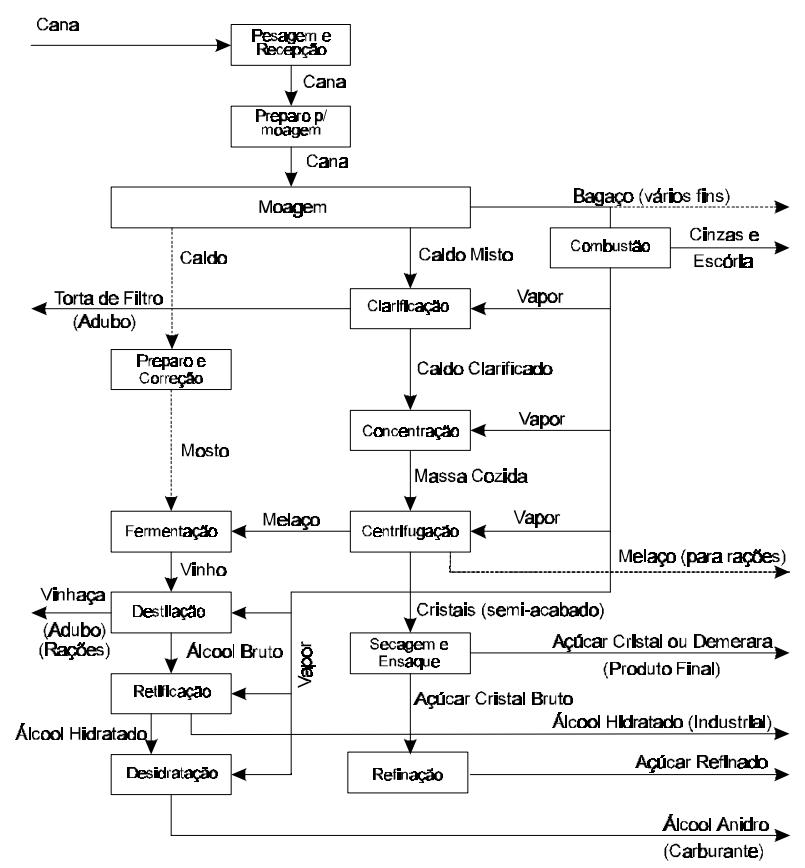

Fig. 3.2 Esquema simplificado da produção de açúcar e álcool em usinas Fonte: IPT (1986), p. 45 
Em geral, a cana é descarregada diretamente dos caminhões para 0 processamento. A alimentação é feita através de mesas onde a cana é lavada a fim de separar as partículas estranhas que são trazidas do campo.

A extração do caldo é feita por moendas. A cana passa por vários ternos que por compressão rompem e separam o caldo do bagaço.

O bagaço é produzido a uma razão média de $250 \mathrm{~kg}$ por tonelada de cana moída, com $50 \%$ de umidade e é utilizado como combustível para geração de vapor de processo e cogeração de energia elétrica (BRASIL, 1986).

O caldo extraído é tratado, clarificado e aquecido. O resfriamento e a secagem do caldo clarificado produz açúcar, que é ensacado para comercialização ou para ser refinado.

A torta de filtro, resíduo da clarificação do caldo, é utilizada como fertilizante devido aos nutrientes e a matéria orgânica que contém.

Na fabricação de álcool, o caldo obtido do processo de moagem é fermentado e o vinho, produto da fermentação, é destilado produzindo álcool bruto e vinhaça.

O álcool hidratado ${ }^{3}$, utilizado nos veículos automotores, é obtido através da retificação do álcool bruto e o álcool anidro ${ }^{4}$, utilizado como aditivo na gasolina, pela desidratação do álcool retificado.

A vinhaça, subproduto da destilação do vinho, é produzida em quantidades elevadas, na proporção de 13 litros por litro de álcool, e é aplicada in natura na fertilização de solos.

A eficiência industrial varia consideravelmente nesta fase em função do processo utilizado e do tipo de instalação. Pode-se observar, em valores fornecidos pelo Conselho de administração das empresas de energia do Estado de São Paulo, para as usinas de açúcar e álcool do Estado, safra 91/92, tabela A.3, que cinco produziram açúcar com rendimento médio de 94,44 kg/tC. A tabela 3.10 mostra a distribuição de usinas e destilarias por tipo de instalação. Em usinas de açúcar

\footnotetext{
${ }^{3}$ Álcool com 93,2 \pm 0,6\% de teor alcoólico.

${ }^{4}$ Álcool com no mínimo 99,3\% de teor alcoólico.
} 
com destilaria anexa ${ }^{5}$ a eficiência na produção de açúcar aumenta, o valor médio é 116,03 kg de açúcar por tonelada de cana e os máximos chegam próximos à140 $\mathrm{kg} / \mathrm{tC}$. Quanto àconversão para álcool, em usinas com destilaria anexa a média de produção é 88,46 la/tC, com valores máximos ultrapassando os $100 \mathrm{la} / \mathrm{tC}$. Em destilarias autônomas ${ }^{6}$ a média é menor, 83,21 la/tC, com a produção variando entre 65 e $92 \mathrm{la} / \mathrm{tC}$.

TABELA 3.10 Distribuição de usinas e destilarias por tipo de instalação

\begin{tabular}{lcccc}
\hline Tipo de instalação & $\begin{array}{c}\text { Quantidade } \\
\text { de usinas }\end{array}$ & $\%$ & $\begin{array}{c}\text { Quantidade de cana } \\
\text { processada [tC] }\end{array}$ & $\%$ \\
\hline Usina de açúcar & 5 & 4,63 & 3.183 .884 & 3,31 \\
Usina de açúcar com & & & & \\
destilaria anexa & 42 & 38,89 & 60.878 .310 & 63,29 \\
Destilaria autônoma & 61 & 56,48 & 32.133 .782 & 33,40 \\
\hline Total & 108 & & 96.195 .976 & \\
\hline
\end{tabular}

As usinas são distribuídas, segundo sua eficiência, em três níveis, que consideram a tecnologia utilizada como responsável pela diferença de rendimentos, tabela 3.11.

TABELA 3.11 Distribuição de usinas e destilarias por nível tecnológico industrial

\begin{tabular}{lcccc}
\hline $\begin{array}{l}\text { Nível } \\
\text { tecnológico }\end{array}$ & \multicolumn{2}{c}{$\begin{array}{l}\text { Usinas de açúcar } \\
\text { destilaria anexa } \\
\text { sem }\end{array}$} & $\begin{array}{l}\text { Destilaria } \\
\text { autônoma }\end{array}$ & $\%$ \\
\hline Baixo & 5 & 9 & 11 & 23,15 \\
Médio & - & 18 & 48 & 61,11 \\
Alto & - & 15 & 2 & 15,74 \\
\hline Total & 5 & 42 & 61 & \\
\hline
\end{tabular}

Os critérios são:

5 Usinas de açúcar com destilaria anexa são unidades industriais que produzem açúcar e álcool. Estas usinas, dependendo das condições de mercado, têm a flexibilidade de produzir mais álcool ou mais açúcar.

${ }^{6}$ Destilarias autônomas são unidades que produzem exclusivamente álcool carburante e químico, utilizando como matéria prima, a cana e outros subprodutos, como o melaço e a aguardente redestilada (PATUSCO, 1985). 
- Conversão com nível tecnológico baixo: usinas de açúcar com produção até $105 \mathrm{~kg}$ de açúcar por tonelada de cana moída ou 75 litros de álcool por tonelada de cana moída e destilarias autônomas que produzem até 75 litros de álcool por tonelada de cana.

- Conversão com nível tecnológico médio: usinas de açúcar com produção acima de $105 \mathrm{~kg}$ de açúcar por tonelada de cana e entre 75 e 90 litros de álcool por tonelada de cana. Destilarias autônomas produzindo na faixa de 75 a 90 litros de álcool por tonelada de cana.

- Conversão com nível tecnológico alto: destilarias autônomas e usinas de açúcar que produzem acima de 90 litros de álcool por tonelada de cana moída e usinas de açúcar com produção acima de 105 kg de açúcar por tonelada de cana.

O estudo de distribuição de usinas e destilarias em níveis tecnológicos industriais é elaborado no anexo $A$.

Os custos médios para a fase de conversão são calculados a partir da "Estrutura de custo da cana-de-açúcar de fornecedores e usinas" elaborada pela Copersucar, que considera uma produção média de $113 \mathrm{~kg}$ de açúcar por tonelada de cana e paridade de 30,83 la/sc. Os valores obtidos são mostrados na tabela 3.12.

TABELA 3.12 Custo de conversão de cana-de-açúcar em açúcar e álcool, para o Estado de São Paulo, safra 1991/92

\begin{tabular}{lcc}
\hline Discriminação & $\begin{array}{c}\text { Açúcar } \\
{[U S \$ / t a]}\end{array}$ & $\begin{array}{c}\text { Álcool } \\
{\left[U S \$ / m^{3}\right]}\end{array}$ \\
\hline Insumos & & \\
Ingredientes e drogas & 5,27 & 8,55 \\
Combustíveis e lubrificantes & 0,34 & 0,54 \\
Sacaria & 12,09 & - \\
Melaço & - & 33,69 \\
\hline Energia elétrica & & \\
Geração própria & 0,90 & 1,47 \\
Comprada & 0,83 & 1,34 \\
\hline Total & 19,43 & 45,59 \\
\hline
\end{tabular}

Fonte: MARQUES (1994). 
A fim de manter a unidade do estudo, não estão incluídos os custos de depreciação, conserto e manutenção dos equipamentos, despesas administrativas e financeiras e mão-de-obra.

Em US\$ $/ 10^{3} \mathrm{GJ}$, unidade utilizada na matriz de coeficientes de impacto, os valores para açúcar e álcool são 1289,15 e 2261,97, respectivamente.

A energia consumida na conversão de cana-de-açúcar em açúcar e álcool é calculada a partir do artigo "Balanço de energia na produção de cana-de-açúcar e álcool nas usinas cooperadas". MACEDO; NOGUEIRA (1985) consideram três fatores na industrialização da cana-de-açúcar:

- a aquisição de energia elétrica;

- a energia necessária para a produção de insumos utilizados no processo industrial, e

- a energia para a construção de edificações e equipamentos industriais e sua manutenção.

O último fator é desconsiderado mantendo o critério utilizado em outras fases do processo energético.

Os valores de consumo e eficiência média, mostrados na tabela 3.13 , são calculados por MACEDO; NOGUEIRA (1985) para dois cenários: um com valores médios e outro com os melhores valores praticados.

TABELA 3.13 Consumo de energia na conversão de cana-de-açúcar em açúcar e álcool

\begin{tabular}{lcccc}
\hline Nível & \multicolumn{2}{c}{ Cenário 1 } & \multicolumn{2}{c}{ Cenário 2 } \\
& $\mathrm{kcal} / \mathrm{tC}$ & $\mathrm{GJ} / 10^{3} \mathrm{GJ}^{(1)}$ & $\mathrm{kcal} / \mathrm{tC}$ & $\mathrm{GJ} / 10^{3} \mathrm{GJ}^{(1)}$ \\
\hline Prod. quím. e lubrif. & 1570 & 1,7 & 1570 & 1,7 \\
Energia elétrica & 3000 & 3,3 & 0 & 0,0 \\
\hline Total & 4570 & 5,0 & 1570 & 1,7 \\
\hline
\end{tabular}

Fonte: MACEDO; NOGUEIRA (1985).

Nota: (1) Valores convertidos a partir da coluna correspondente.

Cenário 1: valores médios de consumo de energia, insumos e investimentos. 
Cenário 2: melhores valores praticados, valores mínimos de consumo e com uso da melhor tecnologia existente e praticada no Estado de São Paulo.

\subsection{Transporte e distribuição}

Após a produção e a transformação da cana-de-açúcar, encerra-se uma grande fase que ocorre totalmente no interior do Estado de São Paulo, em lavouras, usinas e destilarias. Para serem consumidos, os produtos da cana-de-açúcar precisam ser distribuídos, o que é um processo complexo e dispendioso, pois a produção ocorre em diversos pontos distantes dos grandes centros consumidores.

\subsubsection{Transporte e distribuição de álcool etílico}

O transporte de álcool de usinas até companhias de distribuição é controlado pela Petrobrás, que o otimiza através de um programa de computador que considera rotas, modais, consumos e custos envolvidos.

O álcool após ser produzido é armazenado em tanques, em usinas ou destilarias, onde técnicos da Petrobrás analisam a qualidade e autorizam a distribuição.

Cerca de $20 \%$ do álcool produzido permanece na região produtora para abastecêla. O restante é transportado de usinas a um dos terminais armazenadores, primários ou secundário, pertencentes à Petrobrás ou æ̀̀ companhias distribuidoras.

No total são 9 terminais primários localizados em Araraquara, Bauru, Nova Avanhandava, Ourinhos, Ribeirão Preto, Santa Adélia, Santa Maria da Serra, São José do Rio Preto e Sertãozinho, cidades do Estado de São Paulo.

O transporte de usinas aos terminais primários é feito através de caminhões a óleo diesel com capacidade média de transportar 30.000 I de álcool. Estes caminhões percorrem, em média por viagem ida e volta, $133 \mathrm{~km}^{7}$, e consomem 0,67 ld por km rodado (FERREIRA, 1993). Os coeficientes de emissão para

\footnotetext{
${ }^{7}$ Valor calculado no anexo E.
} 
este tipo de veículo são calculados através de relações no anexo $\mathrm{C}$, utilizando os fatores de emissão de caminhões a óleo diesel, e mostrados na tabela 3.14.

O custo do insumo energético utilizado e o consumo de energia dos caminhões que realizam este transporte são, respectivamente, US\$ 30,79 por mil GJ e 5,3 GJ por mil GJ de álcool transportado e foram calculados nos anexos D e B.

TABELA 3.14 Coeficientes de emissão para caminhões utilizados no transporte de álcool das usinas aos centros armazenadores primários

\begin{tabular}{cccccc}
\hline \multicolumn{6}{c}{ Gases de escapamento [t/10 $\left.{ }^{3} \mathrm{GJ}\right]^{*}$} \\
\hline $\mathrm{CO}$ & $\mathrm{HC}$ & $\mathrm{NOx}$ & $\mathrm{SOx}$ & $\mathrm{MP}$ & $\mathrm{CO}_{2}$ \\
0,0039 & 0,0006 & 0,0029 & 0,0013 & 0,0002 & 0,4 \\
\hline
\end{tabular}

Nota: ${ }^{*}$ tonelada de poluente emitido por quantidade de energia transportada (álcool)

Dos terminais primários, parte da produção, aproximadamente $40 \%$, é exportado para outros Estados por ferrovia. Outra parte segue para a Refinaria de Paulínia, Replan, onde é feita a armazenagem secundária do álcool. O álcool etílico que chega a Replan pode ser transportado por três modais: rodovia, ferrovia ou hidrovia.

$\mathrm{Na}$ ferrovia, várias formações são possíveis para transportar o álcool, em geral, segundo SANTOS (1993), as composições são formadas por 17 vagões tanques, cada um com $60 \mathrm{~m}^{3}$ de capacidade e as locomotivas, dependendo do trecho que estão percorrendo, são movidas a óleo diesel ou a eletricidade.

Os trens com tração a óleo diesel transportam cerca de $20 \%$ do álcool etílico produzido no Estado de São Paulo e percorrem dos centros armazenadores primários ao centro armazenador secundário, em média, $310 \mathrm{~km}^{7}$, e consomem segundo VOLF (1994), 0,0122 ld/ $/ \mathrm{m}^{3} / \mathrm{km}$. Os coeficientes de emissão para locomotivas a óleo diesel, mostrados na tabela 3.15, são obtidos a partir de equações desenvolvidas no anexo $\mathrm{C}$.

Os trens com tração elétrica consomem, segundo VOLF (1994), 0,0929 $\mathrm{kWh} / \mathrm{m}^{3} / \mathrm{km}$ e transportaram, em 1991, quase $10 \%$ da produção estadual de álcool etílico. Em média, estes trens percorrem $274 \mathrm{~km}^{7}$ para irem dos centros 
armazenadores primários a Paulínia. O consumo de 4,5 GJ por mil GJ de álcool transportado é $50 \%$ inferior ao consumo de locomotivas a óleo diesel que é de 6,8 $\mathrm{GJ} / 10^{3} \mathrm{GJa}$, anexo B.

TABELA 3.15 Coeficientes de emissão para locomotivas utilizadas no transporte de álcool dos centros armazenadores primários ao centro armazenador secundário

\begin{tabular}{ccccccc}
\hline \multicolumn{8}{c}{ Gases emitidos [t/10 $\left.{ }^{3} \mathrm{GJ}\right]^{*}$} \\
\hline $\mathrm{CO}$ & $\mathrm{HC}$ & $\mathrm{NOx}$ & $\mathrm{SOx}$ & $\mathrm{MP}$ & $\mathrm{HCHO}$ & $\mathrm{CO}_{2}$ \\
0,0030 & 0,0021 & 0,0083 & 0,0013 & 0,0006 & 0,0001 & 0,5 \\
\hline
\end{tabular}

Nota: " tonelada de poluente emitido por quantidade de energia transportada (álcool)

Devido o subsídio concedido ao preço do óleo diesel, a relação entre custo e consumo é inversamente proporcional. Enquanto os trens com tração diesel gastam 39,41 US\$/mil GJ de álcool transportado, os trens com tração elétrica gastam 54,31 , cerca de $38 \%$ a mais ${ }^{8}$.

A hidrovia, em 1991, segundo ARANHA (1994), transportou $40 \mathrm{mil} \mathrm{m}^{3}$ de álcool hidratado; isto correspondeu a $0,6 \%$ da produção de álcool do Estado.

No transporte de álcool pela hidrovia, segundo NORONHA (1993), são utilizados comboios com capacidade de $1.200 \mathrm{~m}^{3}$, formados por um empurrador e quatro chatas. Cada chata com capacidade de transportar $300 \mathrm{~m}^{3}$ de álcool. Este comboio percorre $334 \mathrm{~km}$ de Nova Avanhandava ao terminal de álcool na SP-191 em Santa Maria de Serra, próximo a Piracicaba, a uma velocidade média de 12 $\mathrm{km} / \mathrm{h}$, consumindo, em média, 80 litros de óleo diesel por hora. Os coeficientes de emissão das barcas são calculados no anexo C e constam da tabela 3.16.

O consumo de energia da hidrovia por unidade de energia transportada é o mais baixo de todos os modais, 3,3 GJ por $10^{3} \mathrm{GJ}$ de álcool transportado ${ }^{9}$. Devido o

\footnotetext{
${ }^{8}$ Valores calculados no anexo D.

${ }^{9}$ Valor calculado no anexo B.
} 
baixo consumo de insumo energético, o custo também é o mais baixo entre os modais que transportam álcool, o valor calculado no anexo D, US\$19,33 por mil GJ de álcool transportado, mostra isto.

TABELA 3.16 Coeficientes de emissão para empurradores utilizados no transporte de álcool

\begin{tabular}{cccccc}
\hline \multicolumn{6}{c}{ Gases emitidos $\left[\mathrm{t} / 10^{3} \mathrm{GJ}\right]^{*}$} \\
\hline $\mathrm{CO}$ & $\mathrm{HC}$ & $\mathrm{NOx}$ & $\mathrm{SOx}$ & $\mathrm{MP}$ & $\mathrm{CO}_{2}$ \\
0,0011 & 0,0006 & 0,0030 & 0,0003 & 0,0005 & 0,2 \\
\hline
\end{tabular}

Nota: ${ }^{*}$ tonelada de poluente emitido por quantidade de energia transportada (álcool)

O álcool que chega a Paulínia sem passar pelos centros de armazenamento primário, $11,46 \%$ da produção estadual, são transportados por caminhões semelhantes aos utilizados no transporte de álcool das usinas aos centros de armazenamento primários. São caminhões a óleo diesel compostos por um cavalo mecânico e uma carreta tanque com capacidade de $30 \mathrm{~m}^{3}$. Percorrem, em média $433 \mathrm{~km}$ por viagem ${ }^{7}$ com autonomia de $1,5 \mathrm{~km} / \mathrm{ld}$ (FERREIRA, 1993). Os coeficientes de emissão destes veículos são calculados no anexo C e mostrados na tabela 3.17.

A energia consumida por estes veículos no deslocamento entre as usinas e o centro armazenador secundário em Paulínia é 17,3 GJ por mil GJ de álcool transportado ${ }^{9}$, isto corresponde a 100,26 US\$/mil GJ de álcool transportado ${ }^{8}$.

TABELA 3.17 Coeficientes de emissão para caminhões utilizados no transporte de álcool das usinas ao centro armazenador secundário

\begin{tabular}{cccccc}
\hline \multicolumn{6}{c}{ Gases de escapamento [t/10 $\left.{ }^{3} \mathrm{GJ}\right]^{*}$} \\
\hline $\mathrm{CO}$ & $\mathrm{HC}$ & $\mathrm{NOx}$ & $\mathrm{SOx}$ & $\mathrm{MP}$ & $\mathrm{CO}_{2}$ \\
0,0127 & 0,0021 & 0,0093 & 0,0043 & 0,0006 & 1,3 \\
\hline
\end{tabular}

Nota: ${ }^{*}$ tonelada de poluente emitido por quantidade de energia transportada (álcool) 
De Paulínia, o álcool é distribuído æ̀s companhias distribuidoras nos grandes centros consumidores: São Paulo, Santos, São José dos Campos e Rio de Janeiro, através de dutos e novamente é armazenado, para posteriormente ser distribuído aos postos de combustíveis por caminhões.

Devido ao grande número de centros armazenadores, a última estocagem do produto antes dos postos de combustíveis não é considerada.

A figura 3.3 mostra o sistema transportador e armazenador de álcool.

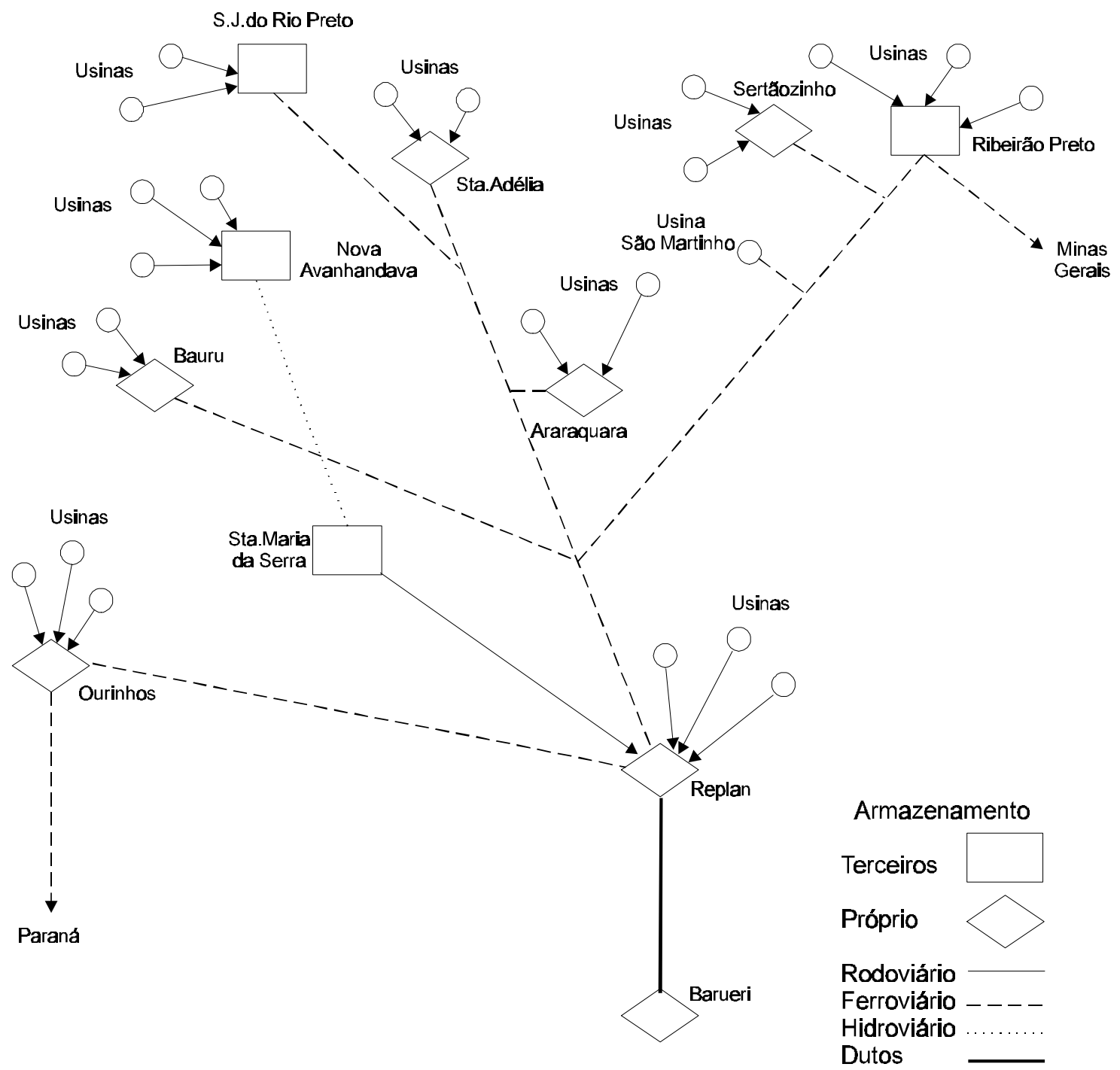

Fig. 3.3 Sistema transportador e armazenador de álcool Fonte: FERREIRA (1993). 
Das bases das companhias distribuidoras nos grandes centros consumidores, ou das usinas nas regiões produtoras, o álcool é distribuído aos postos de combustíveis através de caminhões a óleo diesel. Segundo GUERRIERO (1993), oito tipos de caminhões com seis capacidades diferentes, que variam entre $10 \mathrm{e}$ $32 \mathrm{~m}^{3}$, são utilizados na distribuição de combustíveis.

Os caminhões que fazem a distribuição são agrupados segundo o volume transportado, no anexo $\mathrm{C}$, em três tamanhos: pequenos, médios e grandes.

Os caminhões que realizam a distribuição percorrem em média por viagem ida e volta, $32,5 \mathrm{~km}$ e carregam em volume $20 \%$ de óleo diesel, $35 \%$ de álcool e $45 \%$ de gasolina. Nesta fase, no Estado de São Paulo, o álcool anidro é misturado à gasolina na proporção de 21\% (GUERRIERO, 1993).

Os coeficientes de emissão, consumo de energia e custos envolvidos na distribuição de álcool constam da tabela 3.18 e são calculados nos anexos B, C e D.

TABELA 3.18 Coeficientes de emissão, consumo de energia e custo para caminhões utilizados na distribuição de álcool, por tipo de álcool

\begin{tabular}{lcccccc}
\hline & \multicolumn{5}{c}{$\begin{array}{c}\text { Tamanho do caminhão } \\
\text { médio }\end{array}$} & \multicolumn{2}{c}{ grande } \\
\hline Autonomia [km/l] & \multicolumn{2}{c}{3} & \multicolumn{2}{c}{2,25} & \multicolumn{2}{c}{1,7} \\
\hline $\begin{array}{l}\text { Gases emitidos } \\
\left.\quad \text { [t/10 } \mathbf{G}^{3}\right]^{(1)}\end{array}$ & A.H. & A.A. ${ }^{(2)}$ & A.H. & A.A. ${ }^{(2)}$ & A.H. & A.A. ${ }^{(2)}$ \\
\hline $\mathrm{CO}$ & 0,0070 & 0,0246 & 0,0041 & 0,0145 & 0,0026 & 0,0090 \\
$\mathrm{HC}$ & 0,0011 & 0,0040 & 0,0007 & 0,0024 & 0,0004 & 0,0015 \\
$\mathrm{MP}$ & 0,0003 & 0,0011 & 0,0002 & 0,0007 & 0,0001 & 0,0004 \\
$\mathrm{NOx}$ & 0,0051 & 0,0180 & 0,0030 & 0,0106 & 0,0019 & 0,0066 \\
$\mathrm{SOx}$ & 0,0023 & 0,0082 & 0,0014 & 0,0048 & 0,0009 & 0,0030 \\
$\mathrm{CO}{ }_{2}$ & 0,3 & 1,2 & 0,3 & 1,0 & 0,2 & 0,8 \\
\hline Con.en.[GJ $\left./ 10^{3} \mathrm{GJ}\right]$ & 4,8 & 16,7 & 3,7 & 13,1 & 3,1 & 10,8 \\
\hline Custo $\left[\mathrm{US} \$ / 10^{3} \mathrm{GJ}\right]$ & 27,51 & 96,88 & 21,58 & 76,01 & 17,78 & 62,64 \\
\hline
\end{tabular}

Nota: (1) Tonelada de poluente emitido por quantidade de energia transportada (álcool).

(2) A distribuição de álcool anidro ocorre juntamente com a gasolina. Os valores dos coeficientes de emissão consideram apenas a quantidade de 
álcool anidro transportada, portanto as emissões provenientes da distribuição de gasolina não estão incluídas.

\subsubsection{Transporte de bagaço de cana}

Oitenta e cinco por cento do bagaço de cana produzido é utilizado no setor sucroalcooleiro como combustível para gerar vapor e energia elétrica necessária aos processos industriais em usinas e destilarias. O bagaço não utilizado é comercializado com outras indústrias, em geral, a de cítricos devido a proximidade.

Segundo LODI (1994), o bagaço vendido é transportado por dois tipos de caminhões a óleo diesel. Estes caminhões percorrem em média $100 \mathrm{~km}$, ida e volta, para irem das usinas ou destilarias ao consumidor final.

O primeiro, fechado por tela, conhecido como gaiola, tem capacidade de transportar de 10 a 12 t de bagaço de cana, é utilizado por pequenos consumidores e em locais de difícil acesso. Possui autonomia de $3,5 \mathrm{~km} / \mathrm{ld}$ e transporta aproximadamente $60 \%$ do bagaço comercializado.

O segundo tipo, são caminhões semi-reboque compostos por cavalo mecânico e carreta com paredes de chapa de aço, coberta por lona. As carretas possuem uma capacidade volumétrica de $90 \mathrm{~m}^{3}$, o que corresponde, em média, a $21 \mathrm{t}$ de bagaço de cana. O conjunto possui autonomia de $2 \mathrm{~km} / \mathrm{ld}$ e é utilizado em transporte de bagaço para grandes consumidores, cerca de $40 \%$ do bagaço comercializado.

Os coeficientes de emissão destes veículos são calculados no anexo C e mostrados na tabela 3.19 .

TABELA 3.19 Coeficientes de emissão para caminhões utilizados em transporte de bagaço de cana

\begin{tabular}{lcccccc}
\hline Tipo de & \multicolumn{6}{c}{ Gases de escapamento $\left[\mathrm{t} / 10^{3} \mathrm{GJ}\right]^{*}$} \\
veículo & CO & HC & NOx & SOx & MP & $\mathrm{CO}_{2}$ \\
\hline $12 \mathrm{t}$ & 0,0199 & 0,0032 & 0,0146 & 0,0067 & 0,0009 & 0,9 \\
$21 \mathrm{t}$ & 0,0114 & 0,0019 & 0,0083 & 0,0038 & 0,0005 & 0,9 \\
\hline
\end{tabular}

Nota: * tonelada de poluente emitido por quantidade de energia transportada (bagaço de cana). 
O custo e o consumo de insumo, neste caso óleo diesel, para cada tipo de veículo são calculados no anexo $D$ e $B$ e os valores obtidos são iguais. $O$ custo para transportar $10^{3} \mathrm{GJ}$ de bagaço de cana é US\$ 67,20 e a quantidade de energia consumida é $11,6 \mathrm{GJ} / 10^{3} \mathrm{GJb}$.

\subsection{Consumo}

Nesta fase do processo ocorre o maior impacto ambiental da cana-de-açúcar como fonte de energia. Isto devido as emissões provenientes da transformação de álcool e bagaço em energia útil.

Devido as características e aplicações de cada produto eles são estudados separadamente.

\subsection{1 Álcool etílico}

Em 1991, 55,8\% da produção de álcool etílico foi consumida no Estado de São Paulo e 40,5\% foi exportada para outros Estados.

Observando a figura 3.4 verifica-se que a evolução das exportações de álcool etílico tem um comportamento diferente para cada tipo de álcool. As exportações de álcool hidratado, a partir de 1980 , sempre foram da ordem de $40 \%$ do total da produção estadual, enquanto que a do álcool anidro tiveram dois momentos: de 1980 a 1984, as exportações oscilaram em torno de $65 \%$ e a partir de 1985 elas se estabilizaram em $43 \%$ da produção estadual.

TABELA 3.20 Evolução das exportações de álcool etílico produzido no Estado de São Paulo, em $10^{3} \mathrm{~m}^{3}$

\begin{tabular}{lcccccccccccc}
\hline $\begin{array}{l}\text { Tipo de } \\
\text { álcool }\end{array}$ & \multicolumn{1}{c}{8} & 81 & 82 & 83 & 84 & \multicolumn{1}{c}{85} & \multicolumn{1}{c}{ Ano } & \multicolumn{1}{c}{87} & \multicolumn{1}{c}{88} & \multicolumn{1}{c}{89} & \multicolumn{1}{c}{90} & \multicolumn{1}{c}{91} \\
\hline Anidro & 1.063 & 585 & 926 & 1.027 & 1.084 & 963 & 1.165 & 717 & 627 & 472 & 391 & 653 \\
Hidratado & 456 & 750 & 713 & 1.295 & 1.868 & 2.117 & 1.623 & 2.713 & 2.737 & 2.639 & 2.787 & 2.808 \\
\hline
\end{tabular}

Fonte: SÃO PAULO (1993a), tabela 58. 


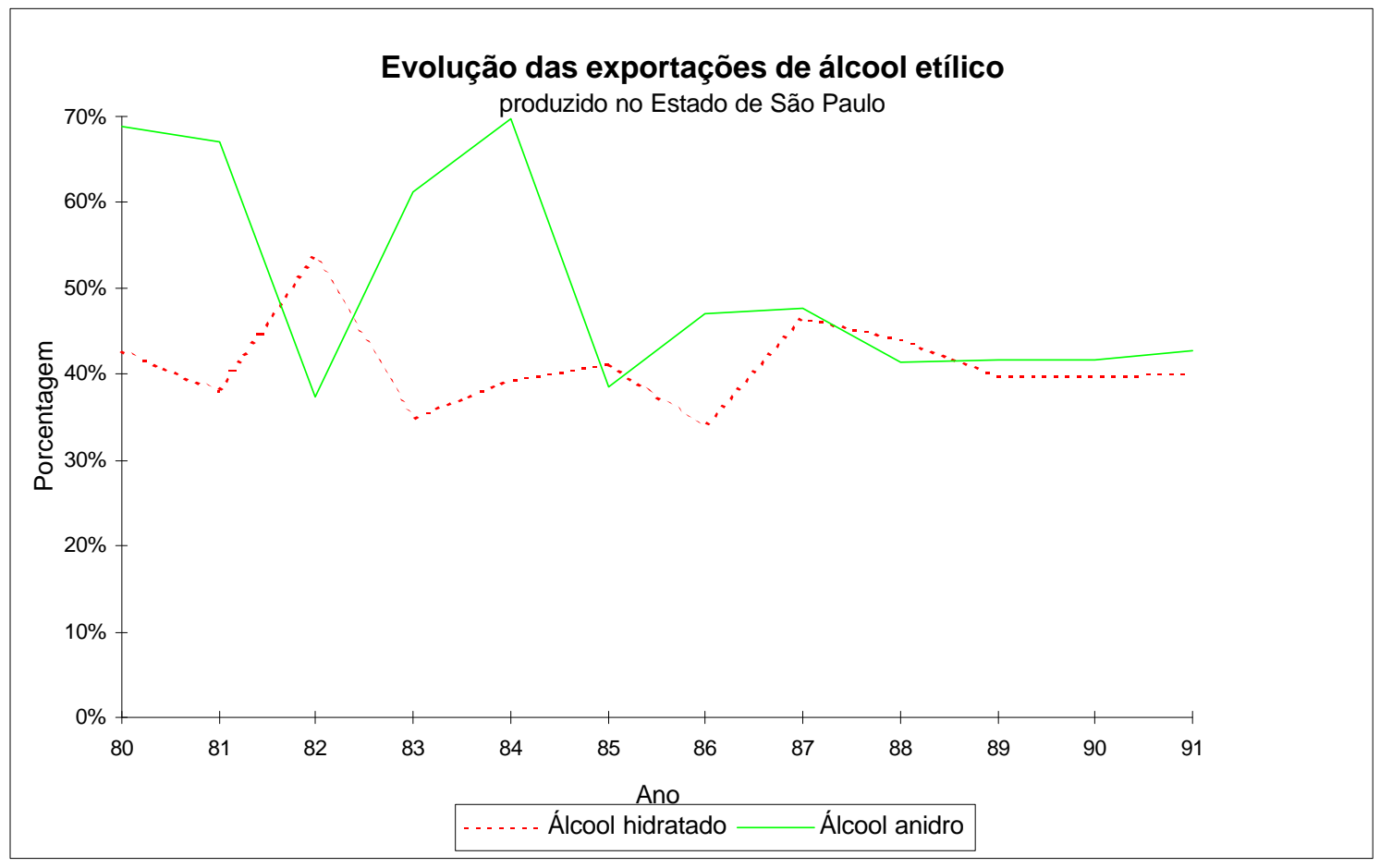

Fig. 3.4 Evolução das exportações de álcool etílico produzido no Estado de São Paulo

O consumo de álcool hidratado em transporte rodoviário de 1981 a 1988 cresceu a taxas altíssimas que variaram de 20 a $60 \%$. A partir de 1988 o consumo retraiu e as taxas de crescimento ficaram em torno de $3 \%$ ao ano. O consumo de álcool anidro é praticamente constante em todo o período analisado, de 1980 a 1991: $52 \%$ da produção estadual.

A figura 3.5 mostra a evolução do consumo de álcool etílico no Estado de São Paulo por setor.

A partir de 1988, no Estado de São Paulo, todo álcool etílico é consumido no setor de transporte rodoviário.

De 1984 a 1987, por determinação do governo federal, os veículos utilizados na produção e transporte de cana deveriam consumir álcool hidratado; este consumo foi contabilizado no setor energético.

Entre 1980 e 1987, o consumo de álcool hidratado no setor não energético, segundo ENNES (1994), refere-se às indústrias químicas que utilizaram álcool hidratado como matéria prima nos seus processos. 


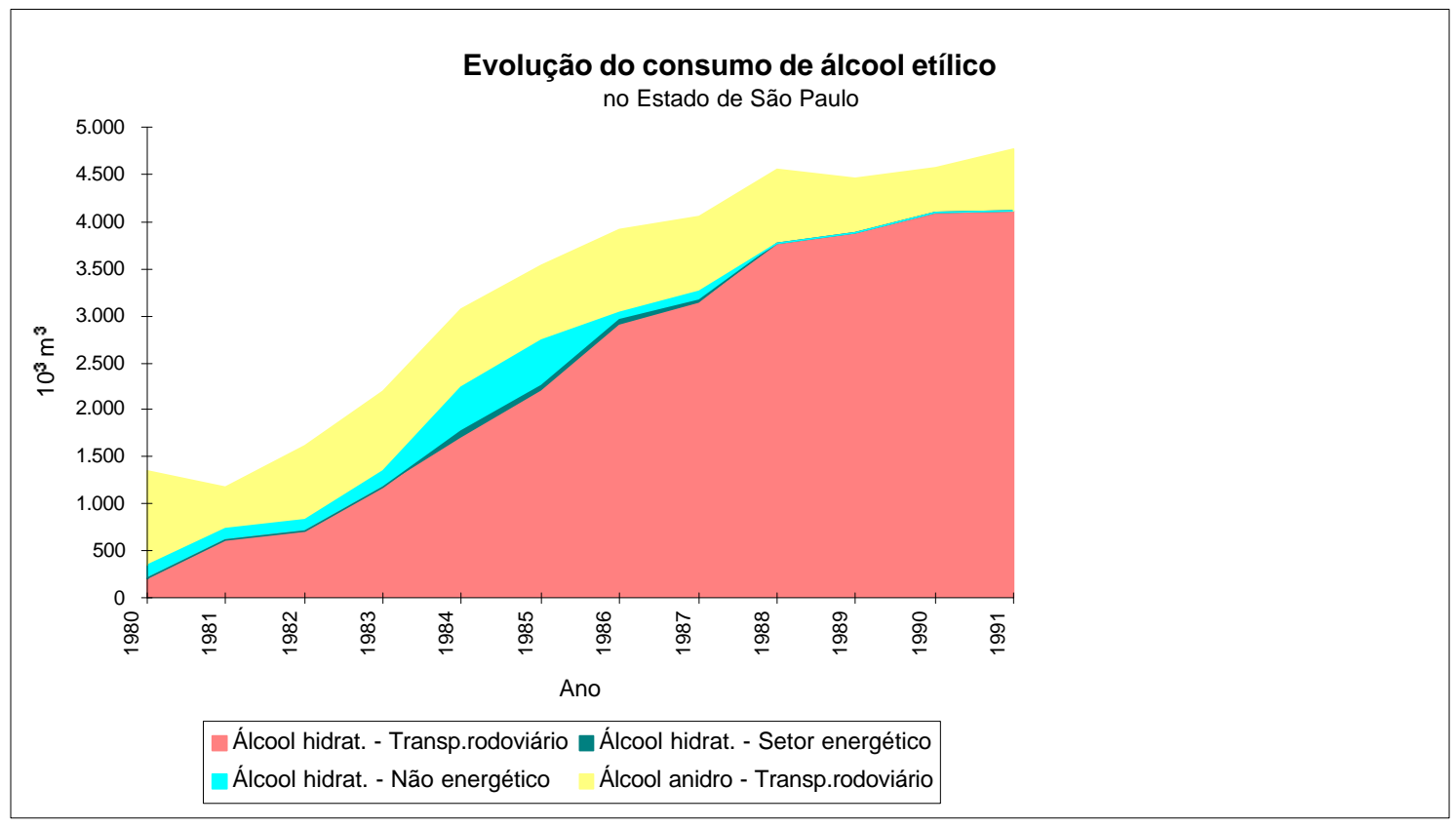

Fig. 3.5 Evolução do consumo de álcool etílico, por setor, no Estado de São Paulo

Fonte: SÃO PAULO (1993a), tabelas 74 e 75

No balanço energético fornecido pelo modelo cascata, as colunas referentes ao álcool etílico no setor de consumo são: transporte rodoviário, exportação e perdas. $\mathrm{Na}$ coluna transporte rodoviário é contabilizada toda energia consumida pelos veículos automotores, na coluna exportação, a quantidade de energia que sai do Estado de São Paulo na forma de álcool etílico para outros Estados. Neste trabalho não são consideradas as emissões provenientes da exportação de álcool etílico. As perdas ocorridas durante as atividades de armazenamento, transporte e distribuição do álcool etílico, após a conversão, estão consideradas nesta fase. Não estão incluídas na fase de consumo as perdas ocorridas em usinas e destilarias.

\subsubsection{Bagaço de cana}

Os grandes consumidores de bagaço são as usinas e destilarias de cana-deaçúcar; cerca de $85 \%$ do bagaço produzido é consumido no próprio setor. Para 
efeito de balanço energético, o bagaço consumido na produção de açúcar é contabilizado na indústria de alimentos e bebidas. O consumo neste setor, mostrado na figura 3.6, teve um grande crescimento entre 1981 e 1983. A partir de 1984 o consumo se estabiliza.

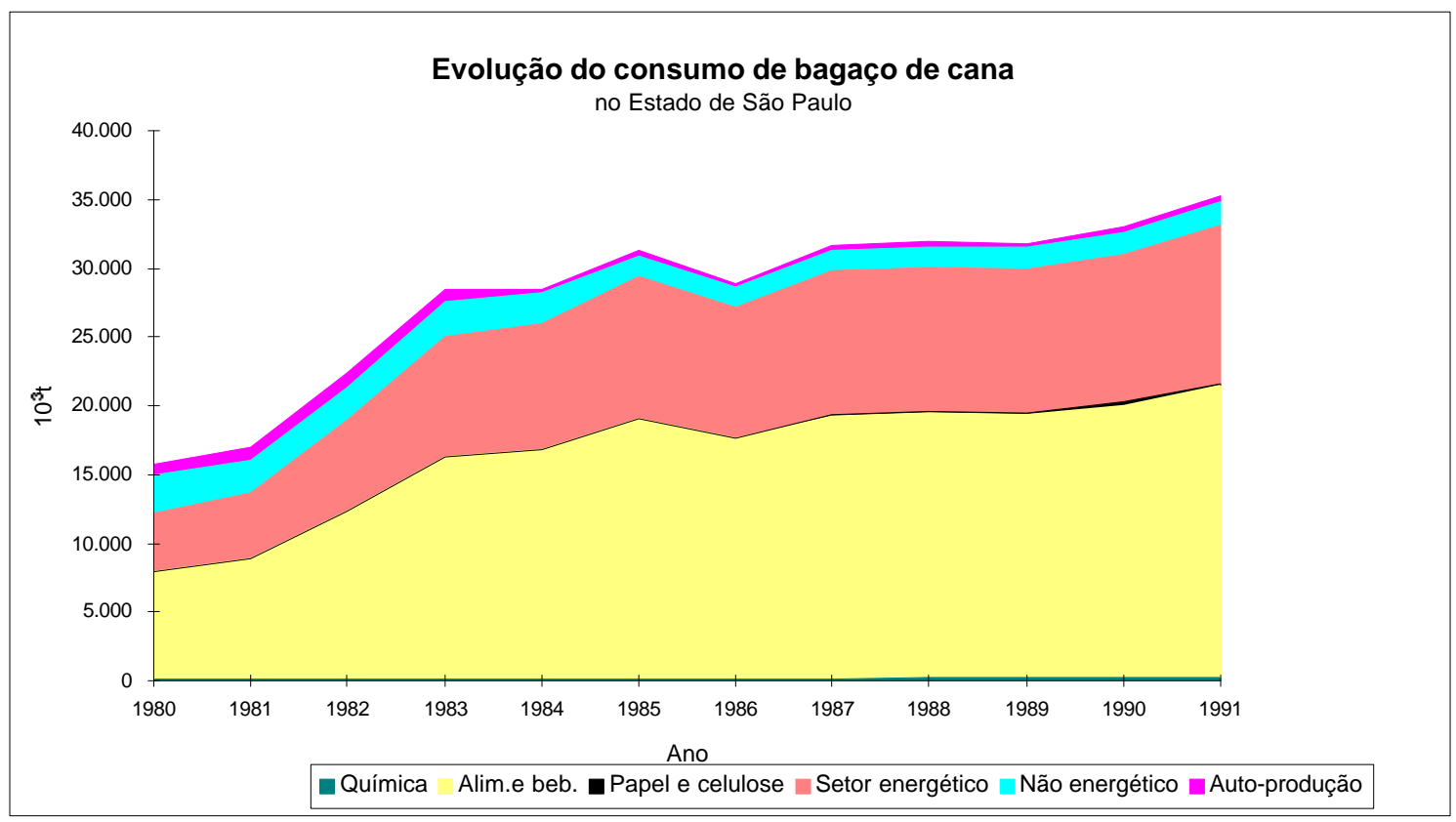

Fig. 3.6 Evolução do consumo de bagaço de cana, por setor, no Estado de São Paulo

Fonte: SÃO PAULO (1993a), tabela 76

Em 1991, o setor de alimentos e bebidas consumiu 57\% do total de bagaço produzido. Segundo LODI (1994), aproximadamente 10\% deste total foi consumido na indústria de cítricos e o restante na produção de açúcar. A indústria de cítricos utiliza bagaço de cana para gerar vapor necessário aos seus processos. Isto é possível devido a proximidade entre as indústrias de cítricos e os centros produtores de bagaço, o que torna o custo de transporte viável.

Outras indústrias utilizam energeticamente bagaço de cana, porém, como pode ser visto na figura 3.6, o consumo ainda é pequeno. A indústria química desde 1980 consome $0,6 \%$ da produção total de bagaço do Estado; uma fração um pouco menor, 0,4\%, é utilizada pela indústria de papel e celulose desde 1987. 
A energia consumida em usinas e destilarias, proveniente da queima de bagaço de cana, na fabricação de álcool é contabilizada na coluna setor energético. $O$ consumo de bagaço no setor energético, a semelhança da indústria de alimentos e bebidas teve um grande crescimento de 1981 a 1983 e a partir de 1984 estabiliza em valores próximos a $31 \%$ do total produzido.

O consumo de bagaço de cana em centrais elétricas auto-produtoras, apesar de pequeno, decresceu de 4\% em 1980 para 1\% em 1983 e permaneceu praticamente constante até 1991.

Fora do setor energético são consumidos aproximadamente $5 \%$ da produção estadual de bagaço. Desde 1980, o bagaço é utilizado como ração para animais, matéria-prima para produção de papel, celulose, e aglomerados e ainda como forração para frangos.

\subsubsection{Não energético}

O único produto da cana-de-açúcar contabilizado no setor não energético é o açúcar. Analisando a figura 3.7, observa-se que a evolução do consumo de açúcar no Estado de São Paulo de 1984 a 1991 é praticamente constante, e é da ordem de 40,0 milhões de sacas de $50 \mathrm{~kg}$.

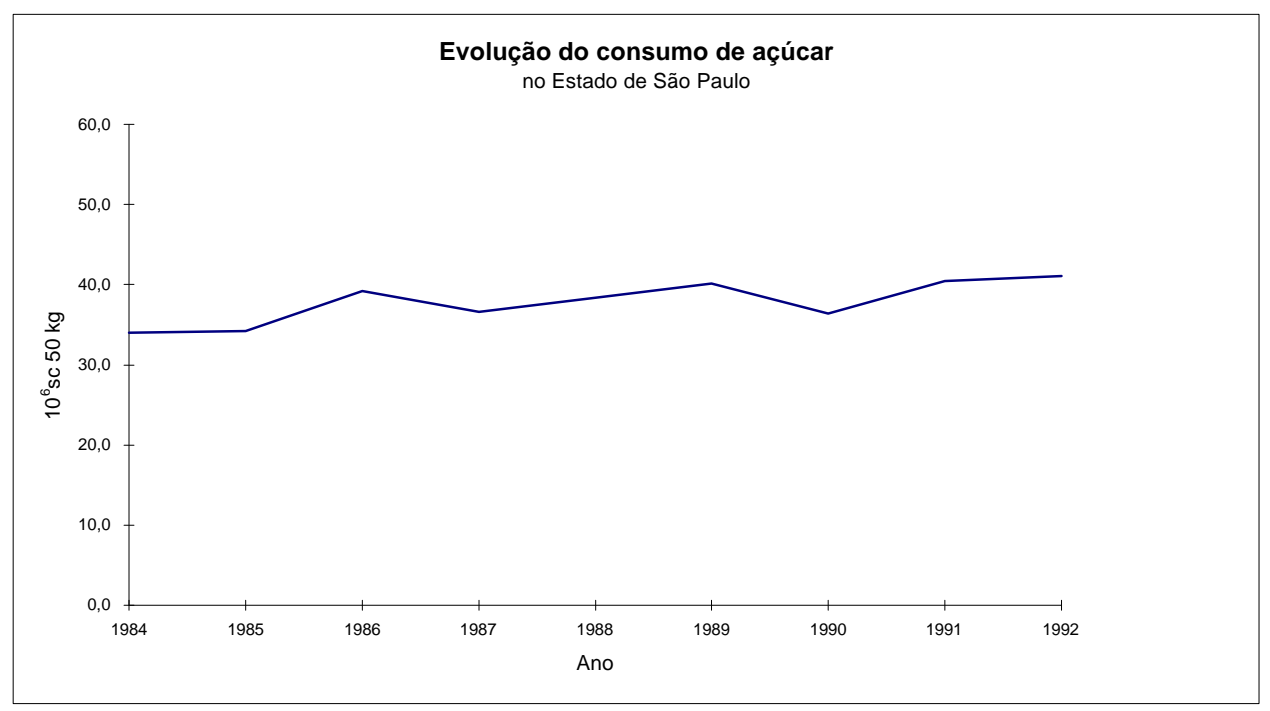

Fig. 3.7 Evolução do consumo de açúcar no Estado de São Paulo Fonte: NOBREGA (1994). 


\subsection{Uso final}

Os produtos da cana-de-açúcar são convertidos, essencialmente, em duas formas de energia útil: força motriz e calor de processo.

$\mathrm{Na}$ força motriz, o álcool é queimado em motores a combustão com baixa eficiência. Segundo SÃO PAULO (1991a), os motores de veículos leves têm uma autonomia média de 6,6 km por litro de álcool.

No anexo $C$ são calculados os coeficientes de emissão que compõe a tabela 3.21. O coeficiente de emissão do dióxido de carbono é fornecido diretamente na tabela C.1. As emissões provenientes da queima de álcool anidro não são consideradas, a fim de evitar dupla contagem. O álcool anidro é utilizado como aditivo da gasolina, portanto as emissões provenientes da sua queima devem ser contabilizadas quando ocorrer a queima da gasolina aditivada.

TABELA 3.21 Coeficientes de emissão para queima de álcool hidratado em motores ciclo Otto

\begin{tabular}{ccccccc}
\hline \multicolumn{7}{c}{ Gases emitidos [t/10 $\left.{ }^{3} \mathrm{GJ}\right]$} \\
\hline $\mathrm{CO}$ & $\mathrm{HC}$ & $\mathrm{NOx}$ & $\mathrm{SOx}$ & $\mathrm{MP}$ & $\mathrm{HCHO}$ & $\mathrm{CO}_{2}$ \\
6,2 & 0,51 & 0,36 & 0 & 0 & 0,052 & 93,7 \\
\hline
\end{tabular}

O preço do álcool hidratado em US $\$ 10^{3}$ GJ é $14.884,64$, e é obtido dividindo o preço por unidade comercial, tabela I.3, pela quantidade de energia por litro de álcool, tabela I.4.

A queima de bagaço de cana em caldeiras, fornece calor de processo, a fim de aquecer fluidos para transferir calor, ou produz vapor necessário a outros processos. Isto é uma prática muito difundida em usinas e destilarias e que vêm sendo adotada por outras indústrias, principalmente do setor de alimentos, na substituição de óleo combustível e lenha.

Estas caldeiras, por serem pouco eficientes possuem altos valores de emissão. Os coeficientes de emissão de caldeiras a bagaço de cana foram calculados a partir 
de equações desenvolvidas no anexo $\mathrm{C}$ e estão relacionados na tabela 3.22. Os coeficientes de emissão de $\mathrm{CO}_{2}$ são obtidos diretamente da tabela C.1.

TABELA 3.22 Coeficientes de emissão para queima de bagaço de cana em caldeiras

\begin{tabular}{cccc}
\hline \multicolumn{4}{c}{ Gases de saída [t/10 $\left.{ }^{3} \mathrm{GJ}\right]$} \\
$\mathrm{NOx}$ & $\mathrm{SOx}$ & $\mathrm{MP}$ & $\mathrm{CO}_{2}$ \\
\hline 0,1 & 0 & 1 & 93,7 \\
\hline
\end{tabular}

A fim de verificar a competitividade do uso de bagaço de cana em caldeiras o custo em US $\$ 10^{3} \mathrm{GJ}$ é calculado no anexo $\mathrm{D}$ e o valor obtido $1.057,80$ refere-se a valores médios praticados em 1991. O custo é obtido dividindo o preço por unidade comercial, tabela I.3, pela quantidade de energia por tonelada de bagaço, tabela I.4.

\subsection{Energia útil}

A energia útil é calculada considerando os rendimentos dos equipamentos utilizados no uso final.

Os produtos da cana-de-açúcar são convertidos em duas formas de energia útil:

- força motriz: onde são utilizados motores a combustão para converter a energia existente no álcool em força motriz, e

- calor de processo: onde são utilizadas caldeiras que queimam bagaço de cana e aquecem água para transferir calor a outros processos.

Segundo WANDERLEY (1987), a eficiência média de queima de motores a combustão é $30 \%$ e de caldeiras que utilizam bagaço de cana como combustível $50 \%$. Estes valores fornecem os resultados obtidos no balanço, sendo que a diferença são perdas que ocorrem durante o uso final do energético. 


\section{RESULTADOS E CENÁRIOS}

\subsection{Resultados}

Os resultados da aplicação do modelo cascata para a cana-de-açúcar e seus produtos no Estado de São Paulo em 1991, são obtidos a partir das informações mostradas nas tabelas 4.1 e 4.2 , fornecidas pelo balanço energético estadual elaborado pela Cesp (SÃO PAULO, 1993a). Estas informações também podem ser obtidas em outras fontes, como por exemplo na Associação das Indústrias de Açúcar e Álcool do Estado de São Paulo (AIAA), na Copersucar, ou ainda diretamente nas destilarias e usinas de açúcar e álcool.

TABELA 4.1 Produção, consumo e exportação de cana-de-açúcar e seus produtos no Estado de São Paulo em 1991

\begin{tabular}{lcr}
\hline & Unidade & \multicolumn{1}{c}{ Total } \\
\hline Produção & & \\
Cana-de-açúcar & {$\left[10^{3} \mathrm{t}\right]$} & 137.281 \\
Álcool anidro & {$\left[10^{3} \mathrm{~m}^{3}\right]$} & 1.526 \\
Álcool hidratado & {$\left[10^{3} \mathrm{~m}^{3}\right]$} & 7.014 \\
Bagaço de cana & {$\left[10^{3} \mathrm{t}\right]$} & 37.066 \\
Açúcar & {$\left[10^{3} \mathrm{sc}\right]$} & 91.300 \\
\hline Consumo & & \\
Álcool anidro & {$\left[10^{3} \mathrm{~m}^{3}\right]$} & 661 \\
Álcool hidratado & {$\left[10^{3} \mathrm{~m}^{3}\right]$} & 4.106 \\
Bagaço de cana & {$\left[10^{3} \mathrm{t}\right]$} & 35.213 \\
Açúcar & {$\left[10^{3} \mathrm{sc}\right]$} & 40.530 \\
\hline Exportação & & \\
Álcool anidro & {$\left[10^{3} \mathrm{~m}^{3}\right]$} & 653 \\
Álcool hidratado & {$\left[10^{3} \mathrm{~m}^{3}\right]$} & 2.808 \\
Bagaço de cana & {$\left[10^{3} \mathrm{t}\right]$} & 0 \\
Açúcar & {$\left[10^{3} \mathrm{sc}\right]$} & 50.314 \\
\hline
\end{tabular}

Fonte: SÃO PAULO (1993a). 
TABELA 4.2 Consumo de bagaço de cana no Estado de São Paulo por setor em 1991

\begin{tabular}{lr}
\hline \multicolumn{1}{c}{ Setor } & $\begin{array}{r}\text { Consumo } \\
{\left[10^{3} \mathrm{tb}\right]}\end{array}$ \\
\hline Química & 221 \\
\hline Alimentos e bebidas & 21.177 \\
Açúcar & 19.059 \\
Cítricos & 2.118 \\
\hline Papel e celulose & 156 \\
\hline Não energético & 1.740 \\
\hline Energético & 11.504 \\
\hline Auto produção & 415 \\
\hline
\end{tabular}

Fonte: SÃO PAULO (1993a), tabela 76.

Outros dados de entrada, necessários ao modelo, são calculados no capítulo 3 e nos anexos com base em informações fornecidas por diversos órgãos que trabalham com cana-de-açúcar e seus produtos. Os valores utilizados são mostrados nas tabelas 4.3, 4.4, 4.5, 4.6, 4.7, 4.8, 4.9, 4.10 e 4.11 e auxiliam na elaboração dos cenários.

TABELA 4.3 Distribuição das unidades agrícolas paulistas por nível tecnológico

\begin{tabular}{lc}
\hline Nível tecnológico & $\%$ \\
\hline Baixo & 28,21 \\
Médio & 56,41 \\
Alto & 15,38 \\
\hline
\end{tabular}

Fonte: TABELA 3.1. 
TABELA 4.4 Distribuição da colheita de cana-de-açúcar no Estado de São Paulo, por forma

\begin{tabular}{lr}
\hline \multicolumn{1}{c}{ Forma de colheita } & \multicolumn{1}{c}{$\%$} \\
\hline Manual com queimada & 83 \\
Mecanizada com queimada & 15 \\
Manual sem queimada & 2 \\
Mecanizada sem queimada & 0 \\
\hline
\end{tabular}

Fonte: KOLLER (1993).

TABELA 4.5 Distribuição do transporte de cana-de-açúcar, por tipo de veículo utilizado no Estado de São Paulo

\begin{tabular}{lr}
\hline \multicolumn{1}{c}{ Veículo utilizado } & \multicolumn{1}{c}{$\%$} \\
\hline Caminhão pequeno & 9 \\
Caminhão médio trucado & 55 \\
Caminhão com um reboque & 32 \\
Caminhão com dois reboques & 4 \\
Caminhão semi-reboque & 0 \\
\hline
\end{tabular}

Fonte: KOLLER (1993).

TABELA 4.6 Distribuição das usinas e destilarias paulistas por nível tecnológico industrial

\begin{tabular}{lc}
\hline Nível tecnológico & $\%$ \\
\hline Baixo & 23,15 \\
Médio & 61,11 \\
Alto & 15,74 \\
\hline
\end{tabular}

Fonte: TABELA 3.11. 
TABELA 4.7 Porcentagem da produção de álcool transportada das usinas aos centros armazenadores primários no Estado de São Paulo

\begin{tabular}{lc}
\hline Tipo de álcool & $\%$ \\
\hline Anidro & 41,56 \\
Hidratado & 27,06 \\
\hline
\end{tabular}

Fonte: TABELA E.6.

TABELA 4.8 Porcentagem da produção de álcool transportada dos centros armazenadores primários ao centro armazenador secundário no Estado de São Paulo, por modal

\begin{tabular}{lr}
\hline \multicolumn{1}{c}{ Modal } & \multicolumn{1}{c}{$\%$} \\
\hline Álcool anidro & \\
Rodoviário & 13,62 \\
Ferroviário diesel & 16,41 \\
Ferroviário elétrico & 12,72 \\
Hidroviário & 0,00 \\
Álcool hidratado & \\
Rodoviário & 10,99 \\
Ferroviário diesel & 20,22 \\
Ferroviário elétrico & 8,58 \\
Hidroviário & 0,57 \\
\hline
\end{tabular}

Fonte: TABELA E.6.

TABELA 4.9 Distribuição dos veículos utilizados na distribuição de álcool etílico no Estado de São Paulo, por tamanho

\begin{tabular}{lr}
\hline Tamanho do caminhão & \multicolumn{1}{c}{$\%$} \\
\hline Pequeno & 8,13 \\
Médio & 64,32 \\
Grande & 27,55 \\
\hline
\end{tabular}

Fonte: TABELA E.5. 
TABELA 4.10 Distribuição dos veículos utilizados na distribuição de bagaço de cana no Estado de São Paulo, por tamanho

\begin{tabular}{lc}
\hline Tamanho do caminhão & $\%$ \\
\hline Pequeno & 60,00 \\
Médio & 40,00 \\
\hline
\end{tabular}

Fonte: LODI (1994).

TABELA 4.11 Eficiência de conversão em energia útil, por uso final

\begin{tabular}{lc}
\hline \multicolumn{1}{c}{ Uso final } & $\%$ \\
\hline Força motriz & 30,00 \\
Calor de processo & 50,00 \\
\hline
\end{tabular}

Fonte: WANDERLEY (1987).

O balanço energético e os impactos estudados para o Estado de São Paulo em 1991, obtidos através do modelo cascata, são mostrados no apêndice II.

O resultado completo, para a cana-de-açúcar e os impactos associados, é constituído de 11 cascatas de matrizes, sendo que: a primeira fornece um balanço energético detalhado, a segunda o mesmo balanço em porcentagem e as demais, informações sobre os impactos estudados: emissões atmosféricas, custos e consumo de energia.

O balanço energético fornecido pelo modelo cascata neste estudo de caso mostra todo o processo produtivo da cana-de-açúcar e as tecnologias utilizadas desde a produção até o uso final.

Com a divisão do processo energético em fases, cada uma delas representada por uma matriz, os impactos mais intensos são facilmente identificados e permitem a elaboração precisa de cenários.

Os resultados dos impactos obtidos no apêndice II: emissões, custos e consumo de energia, são reunidos em tabelas, mostradas a seguir, com o propósito de 
facilitar a leitura e permitir fazer comparações com valores fornecidos por outros organismos e com os cenários propostos.

$\mathrm{Na}$ tabela 4.12 são mostradas as emissões brutas provenientes de cada fase do processo energético da cana-de-açúcar por poluente estudado. Nas fases onde as emissões são expressivas, isto pode ser visto de forma mais clara na tabela 4.13 onde as emissões são relativizadas, as fontes são identificadas com o objetivo de facilitar o diagnóstico e conseqüentemente a atuação do planejador.

A fim de tornar os valores significativos, são incluídas as estimativas das emissões de poluentes, provenientes de fontes móveis e estacionárias, na Região Metropolitana de São Paulo (RMSP) e de processos industriais e queima de combustível em fontes estacionárias em Cubatão (SÃO PAULO, 1993b), tabela 4.14 .

Infelizmente não há estimativas de emissão de todos os poluentes estudados para o Estado de São Paulo.

TABELA 4.12 Estimativas de emissão bruta proveniente do processo energético da cana-de-açúcar no Estado de São Paulo em 1991, por fase e por poluente, [10 ${ }^{3}$ t]

\begin{tabular}{lrrrrrrr}
\hline & $\mathrm{CO}$ & $\mathrm{HC}$ & $\mathrm{MP}$ & $\mathrm{NOx}$ & $\mathrm{SOx}$ & $\mathrm{HCHO}$ & \multicolumn{1}{c}{$\mathrm{CO}_{2}$} \\
\hline $\begin{array}{l}\text { Produção } \\
\text { absorção }\end{array}$ & 0,83 & 0,41 & 0,32 & 2,29 & 0,23 & 0,09 & -216.990 \\
emissão & & & & & & & -217.133 \\
\hline Extração & $5.681,91$ & $1.033,29$ & 465,08 & 1,74 & 0,16 & 0,08 & 3.561 \\
\hline Transporte & 4,54 & 0,74 & 0,22 & 3,31 & 1,52 & 0,00 & 324 \\
\hline Conversão & 0,00 & 0,00 & 0,00 & 0,00 & 0,00 & 0,00 & 0 \\
\hline Transporte & 0,56 & 0,14 & 0,04 & 0,62 & 0,20 & 0,00 & 64 \\
\hline Distribuição & 1,07 & 0,17 & 0,05 & 0,76 & 0,35 & 0,00 & 66 \\
\hline Consumo & 513,09 & 42,21 & 249,04 & 54,70 & 0,00 & 4,30 & 31.089 \\
$\quad$ Álc.hidrat. & 513,09 & 42,21 & 0,00 & 29,79 & 0,00 & 4,30 & 7.754 \\
$\quad$ Bagaço & 0,00 & 0,00 & 249,04 & 24,90 & 0,00 & 0,00 & 23.335 \\
\hline Total & $6.201,97$ & $1.076,96$ & 714,75 & 63,43 & 2,47 & 4,47 & -181.886 \\
\hline
\end{tabular}

Fonte: Modelo cascata 
TABELA 4.13 Contribuição relativa das fases para as emissões de poluentes, por poluente, [\%]

\begin{tabular}{lrrrrrrr}
\hline & \multicolumn{1}{c}{$\mathrm{CO}$} & $\mathrm{HC}$ & \multicolumn{1}{c}{$\mathrm{MP}$} & $\mathrm{NOx}$ & $\mathrm{SOx}$ & $\mathrm{HCHO}$ & $\mathrm{CO}_{2}{ }^{*}$ \\
\hline Produção & 0,01 & 0,04 & 0,05 & 3,61 & 9,46 & 2,02 & 0,41 \\
\hline Extração & 91,61 & 95,94 & 65,07 & 2,74 & 6,51 & 1,71 & 10,10 \\
\hline Transporte & 0,07 & 0,07 & 0,03 & 5,21 & 61,54 & 0,00 & 0,92 \\
\hline Conversão & 0,00 & 0,00 & 0,00 & 0,00 & 0,00 & 0,00 & 0,00 \\
\hline Transporte & 0,01 & 0,01 & 0,01 & 0,98 & 7,98 & 0,08 & 0,18 \\
\hline Distribuição & 0,02 & 0,02 & 0,01 & 1,23 & 14,51 & 0,00 & 0,19 \\
\hline Consumo & 8,27 & 3,92 & 34,84 & 86,22 & 0,00 & 96,19 & 88,20 \\
$\quad$ Álc.hidrat. & 8,27 & 3,92 & 0,00 & 46,97 & 0,00 & 96,19 & 22,00 \\
Bagaço & 0,00 & 0,00 & 34,84 & 39,26 & 0,00 & 0,00 & 66,20 \\
\hline Total & 100,00 & 100,00 & 100,00 & 100,00 & 100,00 & 100,00 & 100,00 \\
\hline
\end{tabular}

Fonte: Modelo cascata.

Nota: * só foram consideradas as emissões

Observando os valores calculados pelo modelo cascata e comparando-os a outra referência, tabela 4.14, fica evidente o potencial poluidor bruto da cana-de-açúcar e seus produtos, sobretudo quando comparado com valores conhecidos.

TABELA 4.14 Comparação entre as estimativas de emissões provenientes do processo energético da cana-de-açúcar e de regiões altamente poluídas, por poluente, $\left[10^{3} \mathrm{t}\right]$

\begin{tabular}{lrrrrrrrrr}
\hline & $\mathrm{CO}$ & $\mathrm{HC}$ & $\mathrm{MP}$ & $\mathrm{NOx}$ & $\mathrm{SOx}$ & $\mathrm{HCHO}$ & $\mathrm{CO}_{2}$ & $\begin{array}{l}\text { Área } \\
{\left[\mathrm{km}^{2}\right]}\end{array}$ \\
\hline Cana-de-açúcar $^{(1)}$ & 6.202 & 1.077 & 715,6 & 63,4 & 2,5 & 4,5 & -181.886 & 16.800 \\
RMSP $^{(2,3)}$ & 1.391 & 233 & 76,9 & 217,3 & 122,2 & & & 8.000 \\
Cubatão $^{(2,4)}$ & & & 31,7 & 17,4 & 18,1 & 4,0 & 162 \\
Estado de São Paulo & & & & & & & $66.730^{(5)}$ & 247.560 \\
\hline
\end{tabular}

Fonte: (1) Modelo cascata.

(2) SÃO PAULO (1993b). 
Notas: (3) estimativa de emissões provenientes de fontes estacionárias e móveis.

(4) estimativa de processos industriais e queima de combustível em fontes estacionárias.

(5) valor correspondente a emissões provenientes da queima de combustíveis fósseis.

A tabela 4.15 mostra que, apesar da pequena quantidade bruta de SOx emitida em Cubatão, comparada a RMSP e a cana-de-açúcar, quando se calcula a emissão por unidade de área o valor se torna considerável.

Com relação a cana-de-açúcar, a área mostrada na tabela 4.14 refere-se apenas a área colhida, portanto a área onde ocorre o consumo não é considerada. Se incluída a área dos centros consumidores de álcool as emissões, relativas a fase de consumo, são reduzidas substancialmente.

TABELA 4.15 Comparação entre as emissões por área provenientes do processo energético da cana-de-açúcar e de regiões altamente poluídas, por poluente, $\left[\mathrm{t} / \mathrm{km}^{2}\right]$

\begin{tabular}{lcrrrrrr}
\hline & $\mathrm{CO}$ & $\mathrm{HC}$ & $\mathrm{MP}$ & $\mathrm{NOx}$ & $\mathrm{SOx}$ & $\mathrm{HCHO}$ & $\mathrm{CO}_{2}$ \\
\hline Cana-de-açúcar & 369 & 64 & 43 & 4 & 0,15 & 0,27 & -10.827 \\
RMSP & 174 & 29 & 10 & 27 & 15 & & \\
Cubatão & & & 196 & 107 & 112 & 25 & \\
Estado de São Paulo & & & & & & & $270^{*}$ \\
\hline
\end{tabular}

Nota: * valor correspondente a emissões provenientes da queima de combustíveis fósseis.

Comparando os valores obtidos nas tabelas 4.12, 4.13, 4.14 e 4.15 é possível concluir que:

- Pela quantidade bruta de poluente emitido no processo energético da cana-deaçúcar, o monóxido de carbono, os hidrocarbonetos e os particulados devem ser objetos de atenção e atuação.

- A emissão de óxidos de nitrogênio ocorre na fase de consumo do processo energético da cana-de-açúcar e apesar de maior do que em Cubatão, é menos prejudicial devido a área de dispersão.

- A emissão de óxidos de enxofre é pequena e provocada, principalmente, devido 
a utilização de óleo diesel pelos caminhões no transporte de cana-de-açúcar.

- A emissão de aldeídos, apesar de pequena, ocorre quase que exclusivamente em virtude do consumo de álcool.

- A cana-de-açúcar, na fase de produção, absorve uma quantidade muito grande de $\mathrm{CO}_{2}$, cerca de 6 vezes mais do que emite.

- A fase de extração da cana-de-açúcar é a que mais contribui para as emissões de $\mathrm{CO}, \mathrm{HC}$ e MP, em função das queimadas que ocorrem no campo.

O balanço entre a produção e o consumo de energia de origem fóssil na produção de cana e seus produtos é bastante favorável. Comparando os valores obtidos através do modelo cascata com os calculados por MACEDO; NOGUEIRA em 1985 pode-se verificar que a ordem de grandeza é a mesma, tabela 4.16. É importante lembrar que MACEDO; NOGUEIRA não consideram as fases de transporte e distribuição.

TABELA 4.16 Consumo de energia no processo energético da cana-de-açúcar e seus derivados no Estado de São Paulo, por fase, $\left[10^{3} \mathrm{GJ}\right]$

\begin{tabular}{lrrrr}
\hline Fase & $\begin{array}{c}\text { Consumo } \\
\text { de energia }\end{array}$ & $\%$ & \multicolumn{2}{c}{ MACEDO; NOGUEIRA } \\
Cenário 1 & Cenário 2 \\
\hline Produção & 15.877 & 61,4 & & \\
Extração & 1.564 & 6,0 & & \\
Transporte & 4.263 & 16,5 & & \\
Conversão & 2.361 & 9,1 & & \\
Transporte & 925 & 3,6 & & \\
Distribuição & 863 & 3,3 & & \\
Insumo de energia fóssil & 25.853 & 100,0 & 29.510 & 25.350 \\
Energia total produzida & 416.240 & & 258.830 & 312.060 \\
Produção/insumo fóssil & 16,1 & & 8,8 & 12,3 \\
\hline
\end{tabular}

Fonte: (1) Modelo cascata.

(2) MACEDO; NOGUEIRA (1985).

Nota: Cenário 1 - valores médios de consumo de energia, insumos e investimentos.

Cenário 2 - melhores valores praticados, valores mínimos de consumo, com a melhor tecnologia existente e praticada no Estado de São Paulo. 
A diferença observada é decorrente da melhoria da eficiência ocorrida durante 0 período de seis anos que separa o estudo feito por MACEDO; NOGUEIRA e este estudo. Para se ter idéia dos valores, a produtividade agrícola anual média utilizada por MACEDO; NOGUEIRA é 65 tC/ha enquanto que em 1991 o valor médio da produtividade agrícola era $81,77 \mathrm{tC} / \mathrm{ha}$, valor calculado no anexo $\mathrm{A}$ e utilizado neste trabalho. Em cinco anos, houve um aumento de $25,8 \%$ na produtividade agrícola. Segundo a COPERSUCAR (1989b), em 1989 o setor sucro-alcooleiro tinha a possibilidade de aumentar em até $11 \%$ a produção total de álcool, bastando para isto otimizar o processo de produção utilizando exclusivamente processos e equipamentos já existentes.

Um problema levantado por FERREIRA; BAJAY (1989) que também pode ser verificado através da utilização do modelo cascata é a dependência do óleo diesel na produção de cana. O consumo de óleo diesel na safra 1991/92 foi $351,210^{3} \mathrm{~m}^{3}$ o que representou $5,5 \%$ do consumo total do Estado. FERREIRA; BAJAY calcularam o consumo de óleo diesel para a safra de 1986/87. O valor obtido, $410,610^{3} \mathrm{~m}^{3}$, representava $7,5 \%$ do consumo total de óleo diesel no Estado. Todos os valores do consumo de energia da tabela 4.16, com exceção da fase de produção, são oriundos do consumo de óleo diesel. $\mathrm{Na}$ fase de produção apenas $17,5 \%$ do consumo de energia provém do consumo de óleo diesel, o restante refere-se a insumos agrícolas. Isto demonstra que quase $50 \%$ da energia consumida no processo energético da cana-de-açúcar é em virtude da utilização de óleo diesel.

A produção de cana-de-açúcar e seus produtos envolve grandes quantias em dinheiro. O total gasto, estimado a partir dos valores do modelo cascata, na safra 91/92 na produção de açúcar e álcool no Estado de São Paulo foi mais de 4 bilhões de dólares, cerca de $1 \%$ do PIB brasileiro. Por envolver grandes quantias em dinheiro, só em insumos energéticos 800 milhões de dólares, e competir com um energético que tem o seu custo relativamente baixo, a redução de custos na produção de açúcar e álcool é constantemente estudada. As fases de transporte e distribuição sempre são citadas como passíveis de redução de custos, mas observando a tabela 4.17 verifica-se que não são onde se conseguiria os melhores resultados. 
A fase onde os resultados de uma atuação são mais expressivos é a conversão, este item corresponde a aproximadamente 98\% dos custos de insumos energéticos necessários a fabricação de álcool, só a matéria prima, ou seja, a cana-de-açúcar representa 36\% dos custos da produção de álcool.

Na produção de cana, a fase mais intensiva em recursos é a produção, nesta fase são utilizados insumos agrícolas, a maior fonte potencial de redução de custos de insumos energéticos. Segundo a COPERSUCAR (1989b), a médio prazo é possível reduzir os custos dos insumos agrícolas em até $18 \%$.

TABELA 4.17 Custo de produção da cana-de-açúcar e seus derivados, e preço ao consumidor no Estado de São Paulo

\begin{tabular}{|c|c|c|c|c|}
\hline & Unidade & Custo & $\%$ & Total $\left[10^{6}\right.$ US $\left.\$\right]$ \\
\hline \multicolumn{5}{|l|}{ Produção } \\
\hline Cana-de-açúcar & [US\$/t] & 2,36 & 100,0 & 325 \\
\hline Produção & & 2,12 & 89,6 & 291 \\
\hline Extração & & 0,07 & 2,8 & 9 \\
\hline Transporte & & 0,18 & 7,6 & 25 \\
\hline Álcool anidro & {$\left[\mathrm{US} \$ / \mathrm{m}^{3}\right]$} & 77,90 & 100,0 & 119 \\
\hline Conversão & & 76,30 & 97,9 & 116 \\
\hline Matéria prima & & 28,36 & 36,4 & 43 \\
\hline Industrialização & & 47,94 & 61,5 & 73 \\
\hline Transporte & & 0,92 & 1,2 & 1 \\
\hline Distribuição & & 0,68 & 0,9 & 1 \\
\hline Álcool hidratado & {$\left[U S \$ / m^{3}\right]$} & 73,50 & 100,0 & 516 \\
\hline Conversão & & 72,56 & 98,7 & 509 \\
\hline Matéria prima & & 26,97 & 36,7 & 189 \\
\hline Industrialização & & 45,59 & 62,0 & 320 \\
\hline Transporte & & 0,70 & 0,9 & 5 \\
\hline Distribuição & & 0,25 & 0,3 & 2 \\
\hline Bagaço de cana & [US\$/t] & 0,06 & & 2 \\
\hline Açúcar & [US\$/sc] & 1,98 & 100,0 & 181 \\
\hline Conversão & & 1,98 & 100,0 & 181 \\
\hline Matéria prima & & 1,01 & 50,9 & 92 \\
\hline Industrialização & & 0,97 & 49,1 & 89 \\
\hline Consumo & & Preço & & \\
\hline Álcool hidratado & [US\$/l] & 0,30 & & 1.232 \\
\hline Bagaço de cana & [US\$/t] & 7,87 & & 20 \\
\hline
\end{tabular}


Fonte: Modelo cascata

A comparação apresentada na tabela 4.18 mostra que os custos dos insumos energéticos utilizados correspondem a aproximadamente $20 \%$ do total do custo de produção da cana-de-açúcar e todos os seus produtos. Isto possibilita concluir que devem ser feitos investimentos em outras áreas do processo da cana-de-açúcar, além do energético, a fim de reduzir custos, uma vez que os custos de mão-deobra, máquinas, despesas administrativas, impostos e taxas não são considerados no modelo cascata e correspondem a $80 \%$.

TABELA 4.18 Comparação entre os custos de produção de cana-de-açúcar

\begin{tabular}{lcrrr}
\hline & Unidade & Custo $^{(1)}$ & Copersucar $^{(2)}$ & $\%$ \\
\hline Cana-de-açúcar & {$[\mathrm{US} \$ / \mathrm{t}]$} & 2,36 & 12,45 & 19 \\
Álcool anidro & {$\left[\mathrm{US} \$ \mathrm{~m}^{3}\right]$} & 77,90 & 356,96 & 22 \\
Álcool hidratado & {$\left[\mathrm{US} \$ \mathrm{~m}^{3}\right]$} & 73,50 & 335,54 & 22 \\
Açúcar & {$[\mathrm{US} \$ / \mathrm{sc}]$} & 1,98 & 10,46 & 19 \\
\hline
\end{tabular}

Fonte: (1) Modelo cascata.

(2) MARQUES (1994).

\subsection{Cenários}

Os cenários propostos buscam, a partir de variáveis exógenas, verificar o comportamento dos impactos a médio prazo com a introdução dos valores no modelo cascata e sua respectiva quantificação.

Os cenários são elaborados para o ano 2010, ano para o qual foram realizados diversos cenários prospectivos, o que permite comparar os valores obtidos com outras referências.

Para facilitar a proposição dos cenários é elaborado um diagnóstico que busca fornecer ao planejador uma radiografia da situação do setor sucro-alcooleiro no ano base, 1991. 


\subsubsection{Diagnóstico}

O diagnóstico elaborado abaixo procura fornecer a situação das variáveis de contexto no ano base, 1991, as quais são alteradas nos cenários e servem de parâmetro de comparação.

A sinopse do diagnóstico é mostrada na tabela 4.19.

\section{Ano base}

No ano base, ou seja em 1991, a situação das variáveis de contexto e políticas era a seguinte:

- A área do Estado de São Paulo cultivada com cana-de-açúcar era $22.415 \mathrm{~km}^{2}$ (SÃO PAULO, 1993c, tabela 7.1.1) e a área colhida foi $16.800 \mathrm{~km}^{2}, 75 \%$ do cultivado, o restante foi utilizado para renovação do canavial.

- A cana-de-açúcar ocupava $32,5 \%$ da área cultivável no Estado. A área total cultivada no Estado de São Paulo era $68.900 \mathrm{~km}^{2}$ (SÃO PAULO, 1993c, tabela 7.0).

- Rendimento agrícola médio: 81,77 tC/ha.

- Trinta e cinco por cento da cana produzida foi moída em destilarias autônomas e os restantes $65 \%$ em usinas com destilarias anexas.

- Nas usinas com destilarias anexas, 35\% da cana foi moída para a produção de açúcar e os restantes $65 \%$ para produção de álcool.

- A produtividade média para usinas com destilarias anexas foi: $116,03 \mathrm{~kg}$ açúcar/tC e 88,46 la/tC. Para destilarias autônomas: 83,21 la/tC.

- A autonomia média dos veículos a gasolina era de $8,3 \mathrm{~km} / \mathrm{l}$ e dos veículos movidos a álcool $6,6 \mathrm{~km} / \mathrm{l}$.

- O álcool anidro representava $15 \%$ em volume na mistura com a gasolina.

- A quilometragem anual média rodada por veículo: $15.000 \mathrm{~km}$ (AIAA, 1992).

- A porcentagem da frota nacional que roda no Estado de São Paulo: 40,4\% automóveis, 26,7\% comerciais leves, 32,9\% comerciais pesados.

- Composição porcentual da frota de automóveis, por categoria, do Estado de São Paulo conforme tabela 4.20. 
TABELA 4.19 Sinopse do diagnóstico do processo energético da cana-de-açúcar para o Estado de São Paulo em 1991

\begin{tabular}{|c|c|c|c|c|c|}
\hline & Situação & Metas e Objetivos & Ações & Bloqueio & Controle \\
\hline Emissões & $\begin{array}{l}\text { - Altas taxas de } \\
\text { emissão: queimada e } \\
\text { consumo }\end{array}$ & - Reduzir emissões & $\begin{array}{l}\text { - Reduzir queimadas } \\
\text { - Melhorar eficiência de } \\
\text { motores ciclo Otto: consumo } \\
\text { e emissões }\end{array}$ & $\begin{array}{l}\text { - Alto custo e baixo } \\
\text { rendimento de máquinas } \\
\text { agrícolas para colheita de } \\
\text { cana crúa } \\
\text { - Limite físico de melhoria de } \\
\text { eficiência de motores }\end{array}$ & $\begin{array}{l}\text { - Incentivar a redução da } \\
\text { utilização de veículos particulares } \\
\text { - Incentivar a utilização de } \\
\text { transporte coletivo }\end{array}$ \\
\hline Consumo & $\begin{array}{l}\text { - Mistura em } 1991 \\
\text { correspondia a } 15 \% \\
\text { de álcool anidro na } \\
\text { gasolina }\end{array}$ & - Reduzir emissões & $\begin{array}{l}\text { - Aumentar a taxa de mistura } \\
\text { para } 22 \%\end{array}$ & $\begin{array}{l}\text { - Limite de produção de } \\
\text { álcool }\end{array}$ & $\begin{array}{l}\text { - Melhorar a eficiência agrícola e } \\
\text { industrial } \\
\text { - Reduzir a venda de veículos a } \\
\text { gasolina } \\
\text { - Alterar o volume de produção } \\
\text { álcool anidro x hidratado }\end{array}$ \\
\hline Frota & $\begin{array}{l}\text { - Composição da } \\
\text { frota em } 1991^{*} \\
\text { - Frota com taxa de } \\
\text { crescimento } 2 \% \text { a.a. }\end{array}$ & $\begin{array}{l}\text { - Reduzir emissões } \\
\text { - Reduzir consumo de } \\
\text { álcool }\end{array}$ & $\begin{array}{l}\text { - Manter a distribuição da } \\
\text { frota nos níveis de } 1991 \\
\text { - Alterar a taxa de produção e } \\
\text { venda de veículos }\end{array}$ & $\begin{array}{l}\text { - Indústria automobilística } \\
\text { - Consumidor }\end{array}$ & \\
\hline $\begin{array}{l}\text { Área } \\
\text { Cultivada }\end{array}$ & $\begin{array}{l}\text { - Extensa área } \\
\text { cultivável, cerca de } \\
32,5 \% \text { da área } \\
\text { cultivável do Estado }\end{array}$ & $\begin{array}{l}\text { - Reduzir a área cultivada } \\
\text { com cana }\end{array}$ & $\begin{array}{l}\text { - Limitar em } 25 \% \text { a área } \\
\text { cultivável do Estado ocupada } \\
\text { por cana }\end{array}$ & $\begin{array}{l}\text { - Aumento da demanda de } \\
\text { álcool }\end{array}$ & $\begin{array}{l}\text { - Melhorar a eficiência agrícola e } \\
\text { industrial } \\
\text { - Importar álcool } \\
\text { - Reduzir a venda de veículos a } \\
\text { álcool }\end{array}$ \\
\hline Custos & $\begin{array}{l}\text { - Custos de produção } \\
\text { inferiores ou iguais } \\
\text { ao de } \\
\text { comercialização }\end{array}$ & $\begin{array}{l}\text { - Manter a } \\
\text { competitividade do álcool } \\
\text { como combustível } \\
\text { alternativo }\end{array}$ & $\begin{array}{l}\text { - Reduzir custos dos } \\
\text { processos } \\
\text { - Melhorar eficiência agrícola } \\
\text { e industrial }\end{array}$ & $\begin{array}{l}\text { - Produtores de álcool } \\
\text { - Necessidade de } \\
\text { investimentos }\end{array}$ & $\begin{array}{l}\text { - Incentivo aos produtores de } \\
\text { álcool }\end{array}$ \\
\hline
\end{tabular}

Nota: * A composição da frota em 1991 está mostrada na tabela 4.20 
TABELA 4.20 Composição porcentual da frota de automóveis, por categoria, do Estado de São Paulo em 1991, [\%]

\begin{tabular}{cccccccc}
\hline \multicolumn{3}{c}{ Automóveis } & \multicolumn{3}{c}{ Comerciais leves } & \multicolumn{3}{c}{ Comerciais pesados } \\
\hline Gasolina & Álcool & Gasolina & Álcool & Diesel & Gasolina & Álcool & Diesel \\
62 & 38 & 45 & 31 & 24 & 3,5 & 1,0 & 95,5 \\
\hline
\end{tabular}

Fonte: LOPES (1994)

\subsubsection{Cenarização}

São propostos 3 cenários para o ano 2010. O primeiro, chamado ambiental, busca minimizar o impacto proveniente das emissões através: de uma penetração maior do álcool como combustível automotivo, do aumento da taxa de mistura gasolinaálcool anidro e da melhoria dos rendimentos agrícola e industrial acima do esperado. Para compensar o aumento da demanda por álcool as usinas com destilarias em anexo produzem álcool no máximo da sua capacidade. O segundo, cenário tendencial, é um cenário moderado que procura representar o ano 2010 a partir da evolução histórica verificada nos anos anteriores ao ano base. $O$ cenário tendencial considera uma estagnação da produção dos veículos movidos a álcool hidratado, a manutenção da taxa de mistura gasolina-álcool anidro e a melhoria dos rendimentos agrícola e industrial nos valores esperados. $O$ último cenário proposto, o reduzido, pretende mostrar o que ocorrerá se for necessário desmontar o programa e para isto considera: redução na fabricação de carros movidos a álcool, a não adição de álcool anidro na gasolina, a estagnação dos rendimentos agrícola e industrial nos níveis do ano base e a produção máxima de açúcar por parte das usinas com destilaria em anexo. Abaixo os cenários são descritos em detalhes.

A fim de facilitar a identificação dos resultados e conseqüentemente as conclusões algumas hipóteses são comuns a todos os cenários:

- Trinta por cento da cana produzida é colhida crua por máquinas agrícolas.

- Vinte e dois e meio por cento da cana colhida é moída em destilarias autônomas e os restantes $77,5 \%$ são moídos em usinas com destilarias anexas 
(SÃO PAULO, 1993c, tabela 7.2).

- Do total de álcool produzido $77 \%$ é hidratado. Este valor pode variar, historicamente, de 35 a $88 \%$, figura 4.1 .

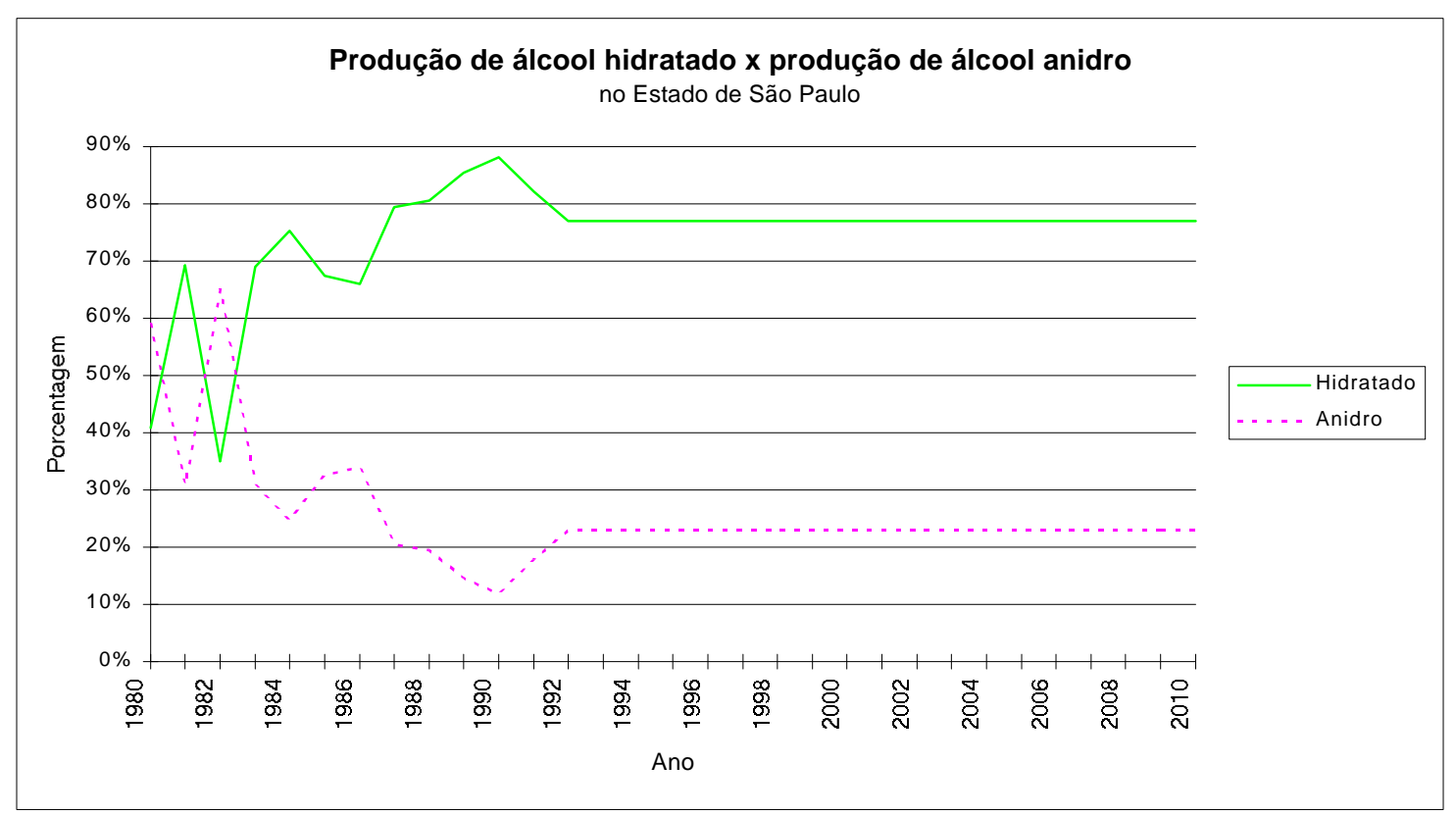

Fig. 4.1 Produção de álcool hidratado x produção de álcool anidro no Estado de São Paulo, em porcentagem

- Quilometragem média anual percorrida por veículo: $15.000 \mathrm{~km} / \mathrm{ano} / \mathrm{veículo,} \mathrm{o}$ mesmo valor do ano base.

- Eficiência dos motores: melhora a taxa de 1\% ao ano, portanto em 2010 os veículos a gasolina passam a percorrer $10,0 \mathrm{~km} / \mathrm{l}$ e os movidos a álcool 8,0 $\mathrm{km} / \mathrm{l}$.

- Taxa de crescimento de vendas de veículos novos: $2 \%$ a.a.

- Porcentagem da frota nacional que circula em São Paulo: 40\%.

- A quantidade de veículos que circula no Estado de São Paulo. A variável é a composição porcentual da frota.

\section{Cenário Ambiental}

A motivação de se propor um cenário ambiental é a discussão que envolve um assunto controverso: as emissões provenientes do processo energético da 
cana-de-açúcar. Neste cenário são propostas ações que visam reduzir as emissões provenientes do processamento e do uso da cana-de-açúcar e seus derivados.

As hipóteses consideradas são:

- Área de colheita estagnada, igual ao ano base: $16.800 \mathrm{~km}^{2}$.

- Produtividade agrícola média aumentada para a projeção ótima da Copersucar: 87,6 tC/ha, (COPERSUCAR, 1989b).

- Rendimento médio das usinas com destilarias anexas: 125,5 kg açúcar/tC e 95,1 la/tC. Para destilarias autônomas: 89,6 la/tC'

- Nas usinas com destilarias anexas, $20 \%$ da cana é moída para a produção de açúcar e os restantes $80 \%$ para produção de álcool ${ }^{2}$.

- Taxa de mistura média de gasolina e álcool anidro para o Estado de São Paulo: $22 \%$

- Veículos a álcool correspondem a 35\% da frota estadual.

- Composição porcentual da frota de automóveis conforme tabela 4.21.

TABELA 4.21 Composição porcentual da frota de automóveis, por categoria, do Estado de São Paulo em 2010 para o cenário ambiental, [\%]

\begin{tabular}{cccccccc}
\hline \multicolumn{2}{c}{ Automóveis } & \multicolumn{3}{c}{ Comerciais leves } & \multicolumn{3}{c}{ Comerciais pesados } \\
\hline Gasolina & Álcool & Gasolina & Álcool & Diesel & Gasolina & Álcool & Diesel \\
60 & 40 & 45 & 30 & 25 & 0,1 & 0,0 & 99,9 \\
\hline
\end{tabular}

\section{Cenário Tendencial}

No cenário tendencial busca-se verificar as conseqüências do crescimento da produção de cana e álcool àtaxas médias atuais sem nenhuma interferência no processo. As hipóteses consideradas são as seguintes:

\footnotetext{
${ }^{1}$ As unidades industriais no cenário ambiental produzem $5 \%$ a mais que as do cenário tendencial.

2 Segundo ACKERMANN (1995) a flexibilidade máxima na produção de açúcar e álcool em usinas com destilarias anexas é $80 \%$ de cana moída para produção de álcool e $20 \%$ para produção de açúcar, ou vice-versa.
} 
- Taxa de crescimento da produção de cana-de-açúcar: 1,85\% a.a., valor calculado através de regressão linear a partir de 1985, figura 4.2.

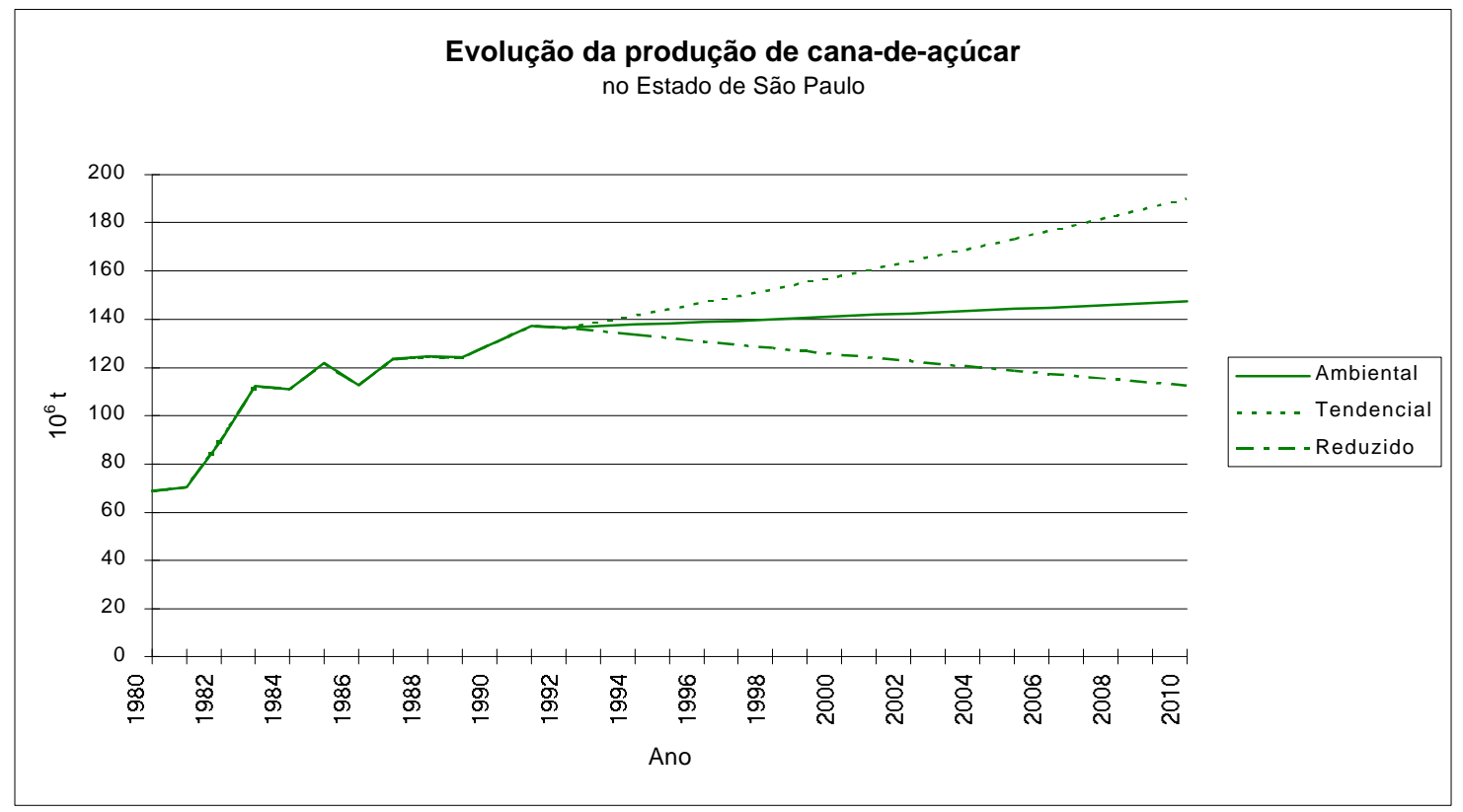

Fig. 4.2 Evolução da produção de cana-de-açúcar no Estado de São Paulo, em diversos cenários

- Produtividade agrícola aumentada para a projeção da Copersucar: 84,8 tC/ha, (COPERSUCAR, 1989b).

- Produtividade média das usinas com destilarias anexas: 119,5 kg açúcar/tC e 90,6 la/tC. Para destilarias autônomas: 85,3 la/tC ${ }^{3}$.

- Nas usinas com destilarias anexas, 35\% da cana é moída para a produção de açúcar e os restantes $65 \%$ para produção de álcool, valor igual ao ano base.

- Taxa de mistura de gasolina e álcool anidro: $15 \%$, valor igual ao ano base.

- Composição porcentual da frota de automóveis conforme tabela 4.22. A participação dos automóveis a álcool nas vendas ao mercado interno tem caído

3 Estes valores foram obtidos da seguinte forma: As unidades com produtividade acima da média em 1991 mantêm a sua produtividade em 2010, as unidades com produtividade entre a média e $90 \%$ da média em 1991, em 2010 passam a produzir na média e finalmente as unidades com produtividade menor que $90 \%$ da média em 1991, passam a produzir 90\% da média em 2010. 
consideravelmente chegando, em dezembro de 1994, a 3,7\% do total (CARTA DE ANFAVEA, 1995).

TABELA 4.22 Composição porcentual da frota de automóveis, por categoria, do Estado de São Paulo em 2010 para o cenário tendencial, [\%]

\begin{tabular}{cccccccc}
\hline \multicolumn{2}{c}{ Automóveis } & \multicolumn{3}{c}{ Comerciais leves } & \multicolumn{3}{c}{ Comerciais pesados } \\
\hline Gasolina & Álcool & Gasolina & Álcool & Diesel & Gasolina & Álcool & Diesel \\
80 & 20 & 55 & 20 & 25 & 0,1 & 0,0 & 99,9 \\
\hline
\end{tabular}

\section{Cenário Reduzido}

O objetivo deste cenário é verificar as alterações decorrentes da redução do consumo de álcool em função da ocorrência dos fatos:

- Alta do preço internacional do açúcar, o que conduziria os produtores a modificarem o perfil de fabricação de açúcar e álcool.

- Fracasso do programa, devido a uma queda ainda maior nos preços internacionais de petróleo.

As hipóteses decorrentes deste cenário são:

- Redução da área plantada de cana. Área de plantio igual a $25 \%$ da área cultivável do Estado: $17.225 \mathrm{~km}^{2}$. Dos $17.225 \mathrm{~km}^{2}, 80 \%\left(13.780 \mathrm{~km}^{2}\right)$ é colhido para moer e os restantes $20 \%$ é para renovação do canavial.

- Produtividade agrícola e industrial estagnada nos valores do ano base: 81,7 tC/ha, 116,0 kg açúcar/tC e 88,5 la/tC para usinas com destilaria anexa e 83,2 la/tC para destilarias autônomas.

- As usinas com destilarias anexas moem $80 \%$ da cana para a produção de açúcar e os restantes $20 \%$ para produção de álcool.

- Redução gradativa da mistura gasolina - álcool anidro até 0\% em 2010.

- Alteração da composição da frota, veículos a álcool são $15 \%$ da frota.

- Composição porcentual da frota de automóveis conforme tabela 4.23. 
TABELA 4.23 Composição porcentual da frota de automóveis, por categoria, do Estado de São Paulo em 2010 para o cenário reduzido, [\%]

\begin{tabular}{cccccccc}
\hline \multicolumn{2}{c}{ Automóveis } & \multicolumn{3}{c}{ Comerciais leves } & \multicolumn{3}{c}{ Comerciais pesados } \\
\hline Gasolina & Álcool & Gasolina & Álcool & Diesel & Gasolina & Álcool & Diesel \\
85 & 15 & 60 & 15 & 25 & 0,1 & 0,0 & 99,9 \\
\hline
\end{tabular}

A sinopse dos cenários é mostrada abaixo na tabela 4.24 .

TABELA 4.24 Sinopse das variáveis dos cenários propostos para a cana-deaçúcar e seus subprodutos para o Estado de São Paulo em 2010

\begin{tabular}{|c|c|c|c|c|}
\hline \multirow[t]{2}{*}{ Variáveis } & \multirow{2}{*}{$\begin{array}{c}\text { Ano base } \\
1991\end{array}$} & \multicolumn{3}{|c|}{ Cenários para 2010} \\
\hline & & Ambiental & Tendencial & Reduzido \\
\hline Área & 16.800 & 16.800 & 22.420 & 13.780 \\
\hline Rendimento agrícola [tC/ha] & 81,7 & 87,6 & 84,8 & 81,7 \\
\hline $\begin{array}{l}\text { Produt. média das usinas anexas } \\
\text { na fabricação de açúcar [kg/tC] }\end{array}$ & 116,0 & 125,5 & 119,5 & 116,0 \\
\hline Produt. média das usinas anexas & & & & \\
\hline na fabricação de álcool [la/tC] & 88,5 & 95,1 & 90,6 & 88,5 \\
\hline $\begin{array}{l}\text { Produt. média das usinas } \\
\text { autônomas na fabricação de }\end{array}$ & & & & \\
\hline álcool [la/tC] & 83,2 & 89,6 & 85,3 & 83,2 \\
\hline Cana moída em usinas anexas & & & & \\
\hline para fabricação de álcool [\%] & 65 & 80 & 65 & 20 \\
\hline Mistura gasolina-álcool anidro [\%] & 15 & 22 & 15 & 0 \\
\hline Composição porcentual da frota & tab. 4.20 & tab. 4.21 & tab. 4.22 & tab. 4.23 \\
\hline
\end{tabular}

\subsubsection{Resultados dos cenários}

Os resultados dos cenários, propostos a partir das hipóteses acima, são mostrados nas tabelas 4.25, 4.27, 4.29 e 4.31 .

Analisando os resultados obtidos e comparando-os aos valores do ano base pode-se observar que no cenário ambiental apesar do pequeno aumento na produção de cana-de-açúcar, 7\%, o aumento na produção de álcool etílico é suficiente para suprir o grande aumento no consumo, 141\% de álcool anidro e $39 \%$ de álcool hidratado, tabela 4.26. Apesar do aumento da produção de álcool 
suficiente para suprir o mercado interno, ele não é suficiente para atender a demanda de exportação se ela se mantiver nos porcentuais do ano base.

TABELA 4.25 Produção, consumo e exportação de cana-de-açúcar e seus produtos no Estado de São Paulo em 2010, por cenário

\begin{tabular}{|c|c|c|c|c|c|}
\hline & \multirow[t]{2}{*}{ Unidade } & \multirow{2}{*}{$\begin{array}{c}\text { Ano base } \\
1991\end{array}$} & \multicolumn{3}{|c|}{ Cenários para 2010} \\
\hline & & & Ambiental & Tendencial & Reduzido \\
\hline \multicolumn{6}{|l|}{ Produção } \\
\hline Cana-de-açúcar & {$\left[10^{3} \mathrm{tC}\right]$} & 137.281 & 147.170 & 190.100 & 112.580 \\
\hline Álcool anidro & {$\left[10^{3} \mathrm{~m}^{3}\right]$} & 1.526 & 2.680 & 2.835 & 840 \\
\hline Álcool hidratado & {$\left[10^{3} \mathrm{~m}^{3}\right]$} & 7.014 & 8.965 & 9.490 & 2.810 \\
\hline Bagaço de cana & {$\left[10^{3} \mathrm{tb}\right]$} & 37.066 & 39.736 & 51.327 & 30.397 \\
\hline Pontas e palhas & {$\left[10^{3} \mathrm{tp}\right]$} & 0 & 5.040 & 6.726 & 4.134 \\
\hline Açúcar & {$\left[10^{3} \mathrm{sc}\right]$} & 91.300 & 57.256 & 123.240 & 161.935 \\
\hline \multicolumn{6}{|l|}{ Consumo } \\
\hline Álcool anidro & {$\left[10^{3} \mathrm{~m}^{3}\right]$} & 661 & 1.590 & 1.400 & 0 \\
\hline Álcool hidratado & {$\left[10^{3} \mathrm{~m}^{3}\right]$} & 4.106 & 5.715 & 3.075 & 2.363 \\
\hline Bagaço de cana & {$\left[10^{3} \mathrm{t}\right]$} & 35.213 & 37.749 & 48.761 & 28.877 \\
\hline Açúcar & {$\left[10^{3} \mathrm{sc}\right]$} & 40.530 & 53.800 & 53.800 & 53.800 \\
\hline \multicolumn{6}{|l|}{ Exportação } \\
\hline Álcool anidro & {$\left[10^{3} \mathrm{~m}^{3}\right]$} & 653 & 1.063 & 1.407 & 832 \\
\hline Álcool hidratado & {$\left[10^{3} \mathrm{~m}^{3}\right]$} & 2.808 & 3.160 & 6.320 & 419 \\
\hline Bagaço de cana & {$\left[10^{3} \mathrm{t}\right]$} & 0 & 0 & 0 & 0 \\
\hline Açúcar & {$\left[10^{3} \mathrm{sc}\right]$} & 50.314 & 3.170 & 68.824 & 107.325 \\
\hline
\end{tabular}

Outro fator importante é o aumento da disponibilidade de pontas e palhas de cana, devido a utilização de máquinas agrícolas na colheita de cana-de-açúcar. Isto provoca um aumento no material a ser queimado nas usinas e conseqüentemente na quantidade de energia a ser gerada, tornando a relação produção/consumo de insumos maior.

A produção de açúcar no cenário ambiental foi reduzida em 37\% e o total produzido é suficiente para atender a demanda do Estado de São Paulo. As quantidades exportadas não são suficientes para atender o mercado externo o que acarretará um problema de abastecimento. Isto ocorre por optar-se em produzir mais álcool, a fim de atender o consumo veicular e conseqüentemente reduzir as emissões. A evolução da produção e consumo de álcool e açúcar é 
mostrada nas figuras $4.3,4.4$ e 4.5 .

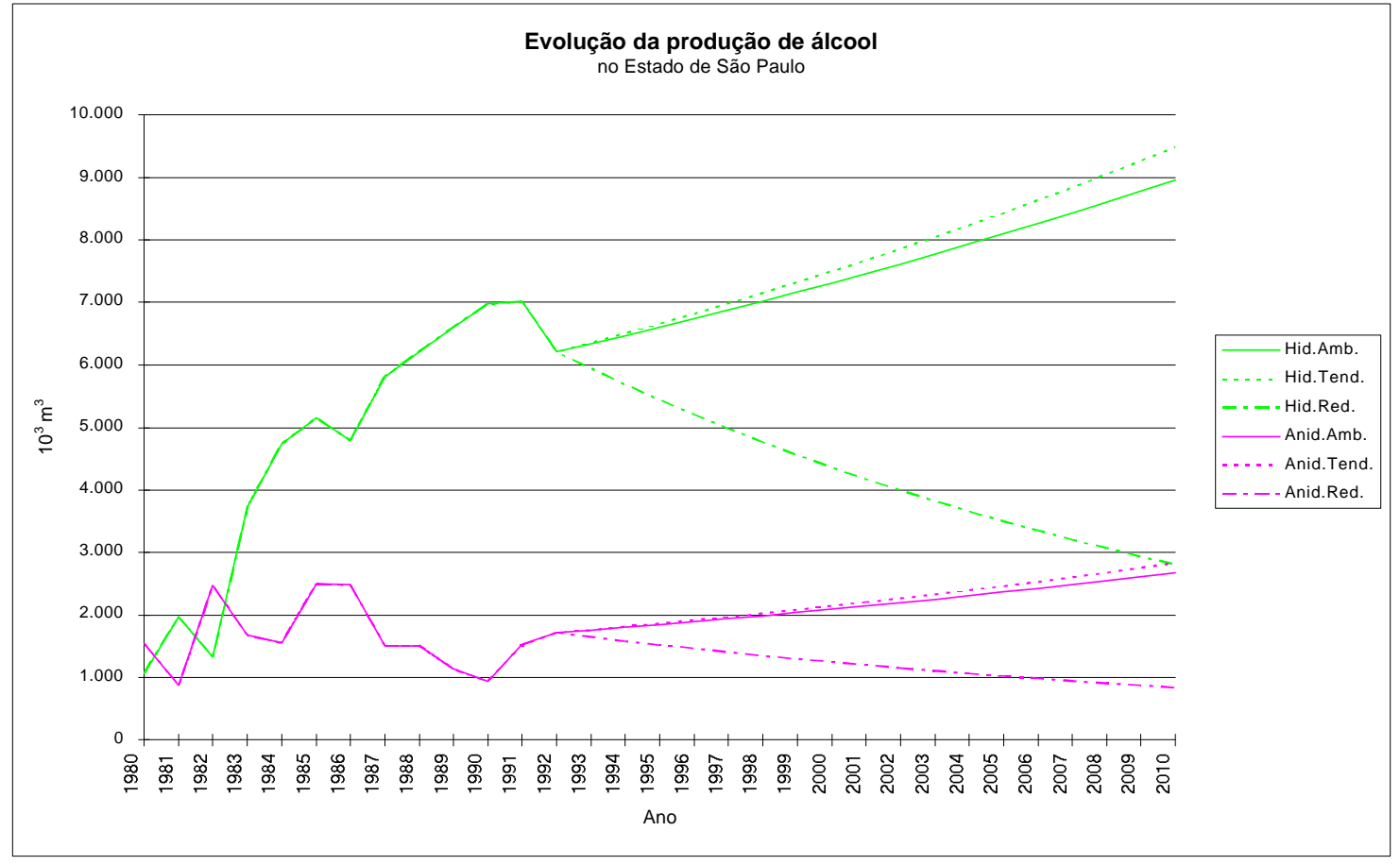

Fig. 4.3 Evolução da produção de álcool no Estado de São Paulo, em diversos cenários

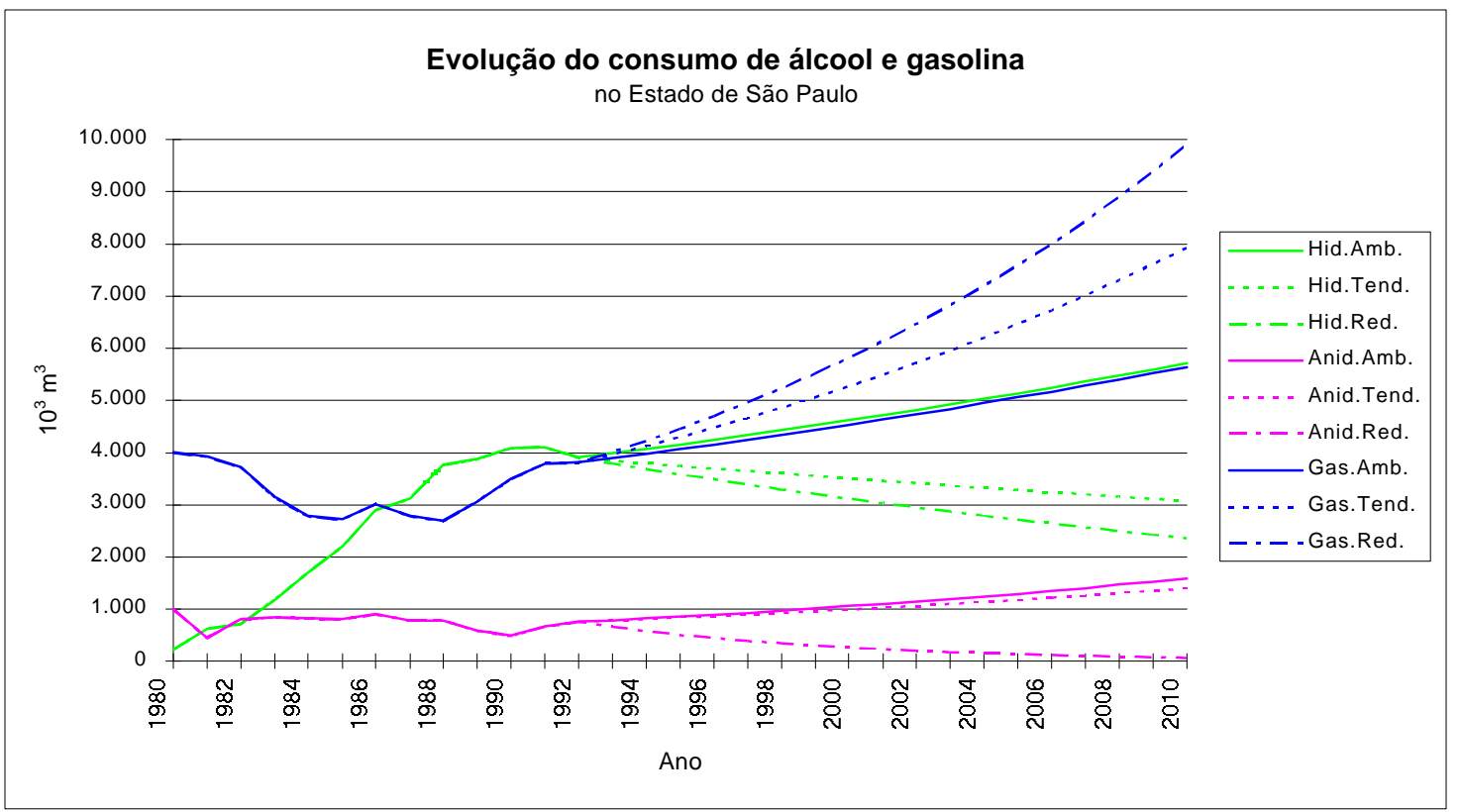

Fig. 4.4 Evolução do consumo de álcool e gasolina no Estado de São Paulo, em diversos cenários 


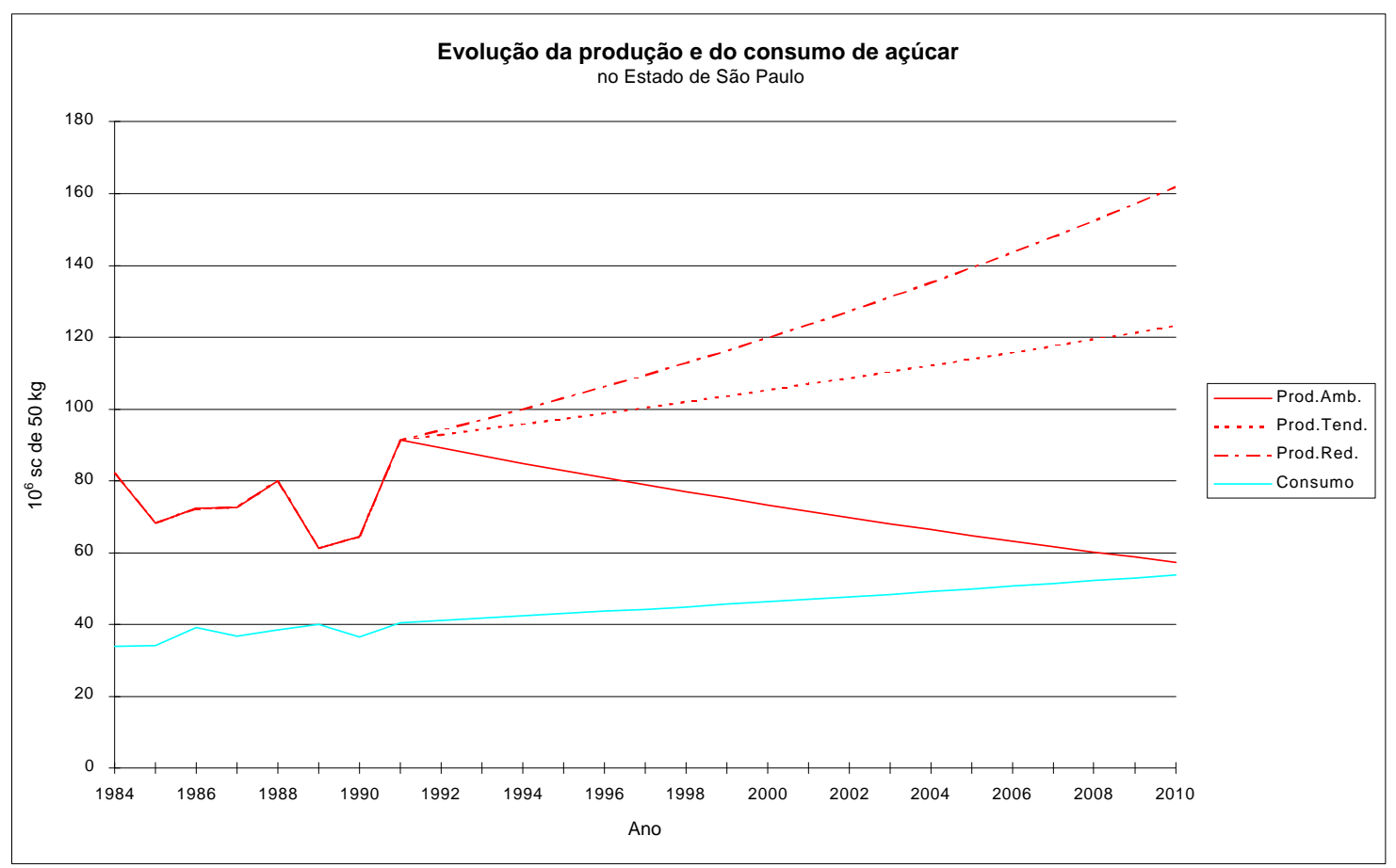

Fig. 4.5 Evolução da produção e do consumo de açúcar no Estado de São Paulo, em diversos cenários

O cenário tendencial apresenta um crescimento de $38 \%$ na produção de cana-deaçúcar, 44\% na produção de álcool etílico e 35\% na produção de açúcar, valores suficientes para suprir o aumento no consumo de álcool anidro, em virtude do aumento das vendas de veículos a gasolina. Com a redução das vendas de veículos a álcool e conseqüentemente do consumo de álcool hidratado, a disponibilidade de álcool para exportação aumenta consideravelmente, podendo suprir diversas regiões do país.

O consumo interno e externo de açúcar também não fica comprometido neste cenário, tendo em vista que o aumento da produção é suficiente para atender o Estado e as necessidades de exportação.

No cenário reduzido, todas as variáveis energéticas são diminuídas em proveito dos produtos não-energéticos. Apesar da sensível redução na produção de álcool, $57 \%$, o mercado interno não sofre desabastecimento mas as exportações de álcool hidratado ficam seriamente comprometidas. As de álcool anidro não sofrem 
alteração uma vez que neste cenário foi abandonado o uso de álcool anidro como aditivo.

Em compensação, a produção de açúcar abastece o mercado interno e pode ser exportada para atender grandes mercados consumidores, inclusive internacionais.

TABELA 4.26 Variação porcentual da produção, consumo e exportação de canade-açúcar e seus produtos em 2010 comparado ao ano base [\%]

\begin{tabular}{lrrr}
\hline & \multicolumn{3}{c}{ Cenários para 2010} \\
& & & \\
& Ambiental & Tendencial & Reduzido \\
\hline Produção & & 38 & -18 \\
Cana-de-açúcar & 76 & 86 & -45 \\
Álcool anidro & 28 & 35 & -60 \\
Álcool hidratado & 7 & 38 & -18 \\
Bagaço de cana & -37 & 35 & 77 \\
Açúcar & & & \\
\hline Consumo & 141 & 112 & -100 \\
Álcool anidro & 39 & -25 & -42 \\
Álcool hidratado & 7 & 38 & -18 \\
Bagaço de cana & 33 & 33 & 33 \\
Açúcar & & & \\
\hline Exportação & 63 & 115 & 27 \\
Álcool anidro & 13 & 125 & -85 \\
Álcool hidratado & 0 & 0 & 0 \\
Bagaço de cana & -94 & 37 & 113 \\
Açúcar & & &
\end{tabular}

O resultado dos cenários para emissões atmosféricas provenientes do processo energético da cana-de-açúcar são mostrados na tabela 4.27. As figuras 4.6, 4.7, 4.8 e 4.9 mostram a evolução dos impactos dos diversos poluentes sobre a atmosfera a partir do ano base.

Analisando os valores obtidos pode-se concluir:

- No cenário ambiental as emissões de CO, HC e MP decrescem pois, apesar do aumento da produção de cana-de-açúcar e do consumo de bagaço de cana, a maior fonte de emissão destes poluentes, a queimada antes da colheita, diminui. O aumento das emissões de SOx é decorrente do aumento do 
transporte de cana-de-açúcar do campo para as usinas e da distribuição de álcool para o consumo, uma vez que a produção de cana e de álcool tiveram um aumento de $7 \%$ e $36 \%$ respectivamente. O aumento do consumo de álcool hidratado e bagaço de cana são os responsáveis pelo aumento das emissões de $\mathrm{NOx}$ e HCHO. O aumento da absorção de $\mathrm{CO}_{2}$ é decorrente do aumento da área plantada com cana-de-açúcar, inclusive as taxas de aumento são muito próximas.

TABELA 4.27 Estimativas de emissão bruta proveniente do processo energético da cana-de-açúcar no Estado de São Paulo em 2010, por poluente, [10³ t]

\begin{tabular}{lrrrr}
\hline Poluentes & Ano base & \multicolumn{3}{c}{ Cenários para 2010 } \\
& \multicolumn{1}{c}{1991} & Ambiental & Tendencial & Reduzido \\
\hline $\mathrm{CO}$ & 6.202 & 4.949 & 5.854 & 3.534 \\
$\mathrm{HC}$ & 1.077 & 829 & 1.027 & 614 \\
$\mathrm{MP}$ & 715 & 614 & 793 & 470 \\
$\mathrm{NOx}$ & 63 & 79 & 70 & 45 \\
$\mathrm{SOx}$ & 2,47 & 2,89 & 3,48 & 1,88 \\
$\mathrm{HCHO}$ & 4,47 & 6,22 & 3,52 & 2,65 \\
$\mathrm{CO}_{2}$ & -181.886 & -193.483 & -258.121 & -151.890 \\
\hline
\end{tabular}

- O cenário tendencial também apresenta redução na quantidade de emissões de $\mathrm{CO}$ e HC, apesar do aumento da produção de cana-de-açúcar, devido a redução das queimadas antes da colheita. A quantidade de MP, sofre um aumento porque, apesar da redução das queimadas, a quantidade de bagaço de cana queimado para produção de energia nas usinas aumenta consideravelmente. O motivo do aumento da emissão de SOx é o mesmo do cenário ambiental: o aumento do transporte de cana e da distribuição de álcool em razão do aumento da produção de cana e álcool. O aumento das emissões de NOx no cenário tendencial ocorre por causa do consumo de bagaço de cana e só não é maior porque neste cenário há uma redução no consumo de álcool hidratado, o que também provoca a redução das emissões de $\mathrm{HCHO}$. A absorção de $\mathrm{CO}_{2}$ também aumenta provocada pelo aumento da produção de cana-de-açúcar. 
TABELA 4.28 Variação porcentual da emissão bruta proveniente do processo energético da cana-de-açúcar no Estado de São Paulo em 2010, por poluente, comparado ao ano base [\%]

\begin{tabular}{lrrr}
\hline Poluentes & \multicolumn{3}{c}{ Cenários para 2010 } \\
& Ambiental & Tendencial & Reduzido \\
\hline $\mathrm{CO}$ & -20 & -6 & -43 \\
$\mathrm{HC}$ & -23 & -5 & -43 \\
$\mathrm{MP}$ & -14 & 11 & -34 \\
$\mathrm{NOx}$ & 25 & 11 & -29 \\
$\mathrm{SOx}$ & 17 & 41 & -24 \\
$\mathrm{HCHO}$ & 39 & -21 & -41 \\
$\mathrm{CO}_{2}$ & 6 & 42 & -16 \\
\hline
\end{tabular}

- Todas as emissões provenientes do processo energético da cana no cenário reduzido diminuem, isto ocorre devido a redução de todos os parâmetros do modelo. A análise deve ser cuidadosa pois apesar dos valores brutos diminuírem os valores líquidos devem aumentar, examinando a figura 4.4 observa-se que enquanto o consumo de álcool hidratado reduz-se a metade, 0 consumo de gasolina aumenta 1,5 vez. As emissões provenientes do consumo de gasolina não estão computadas.

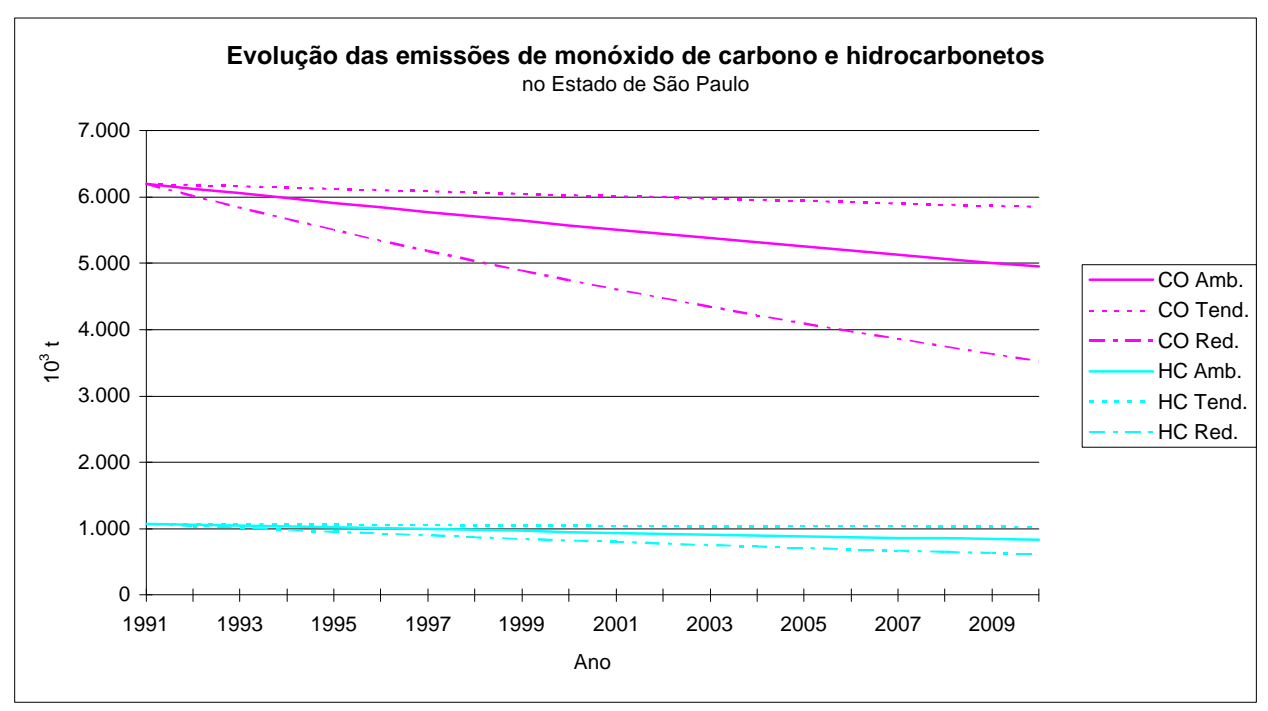

Fig. 4.6 Evolução das emissões de monóxido de carbono e hidrocarbonetos no Estado de São Paulo, em diversos cenários 


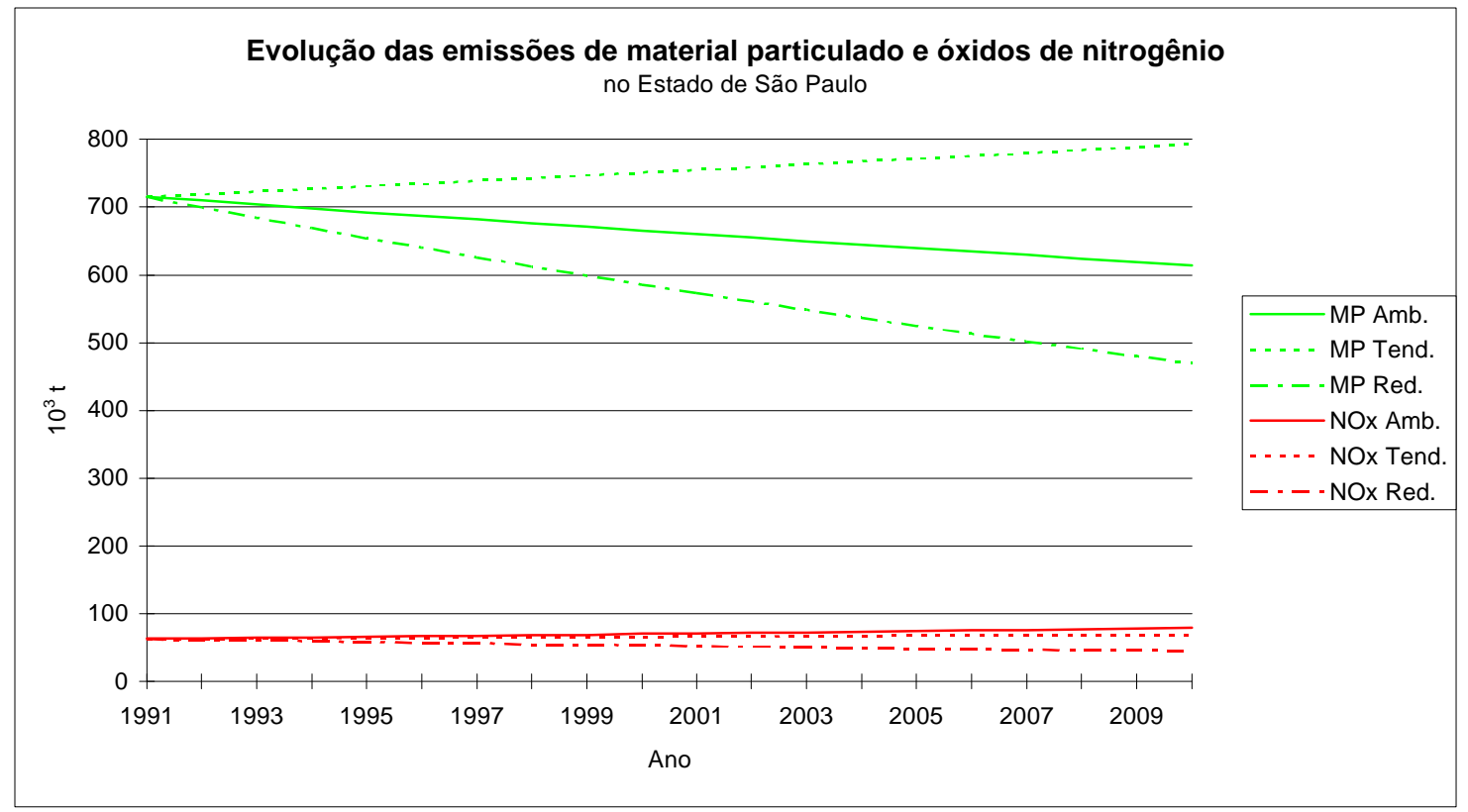

Fig. 4.7 Evolução das emissões de material particulado e óxidos de nitrogênio no Estado de São Paulo, em diversos cenários

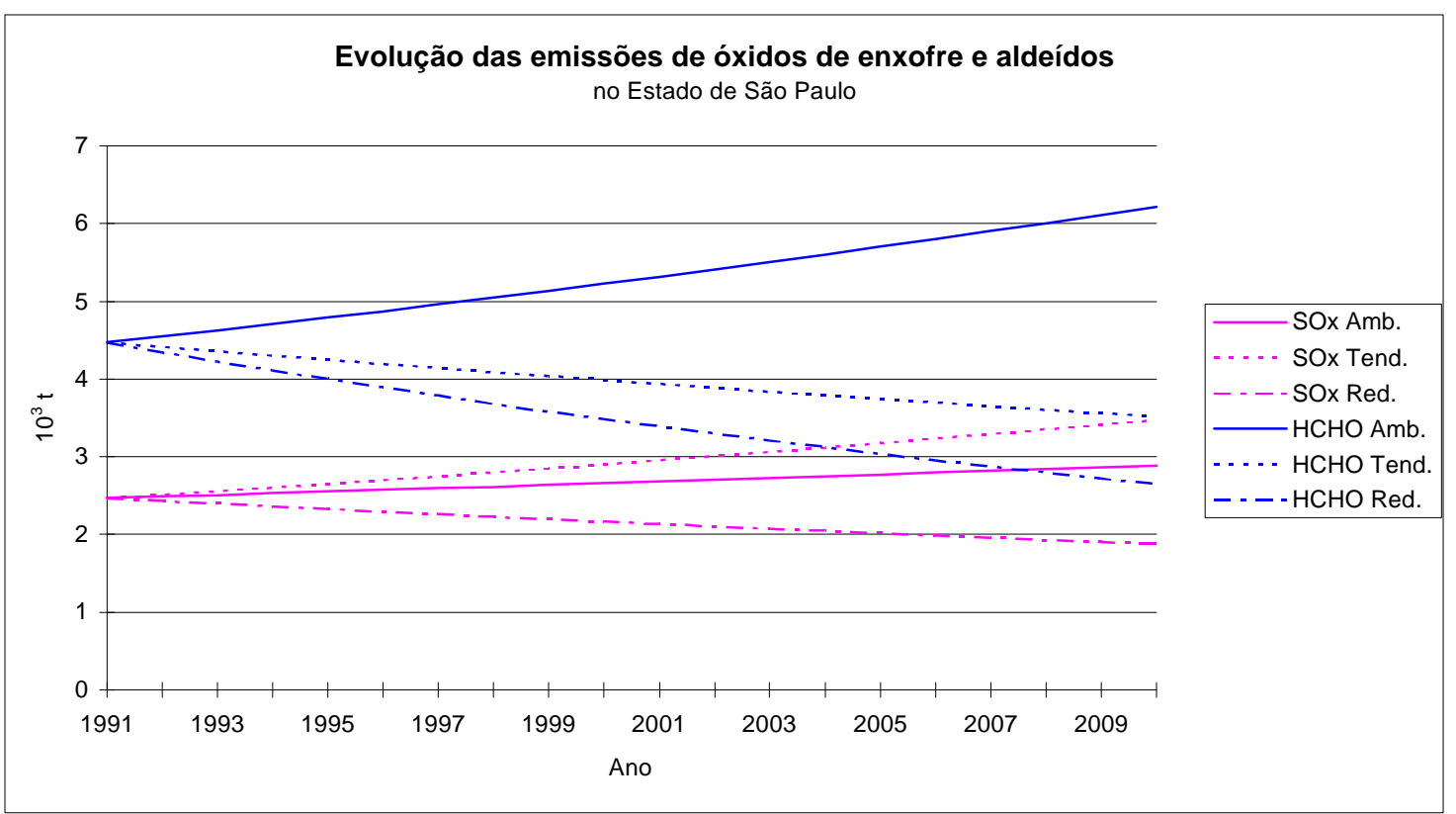

Fig. 4.8 Evolução das emissões de óxidos de enxofre e aldeídos no Estado de São Paulo, em diversos cenários 


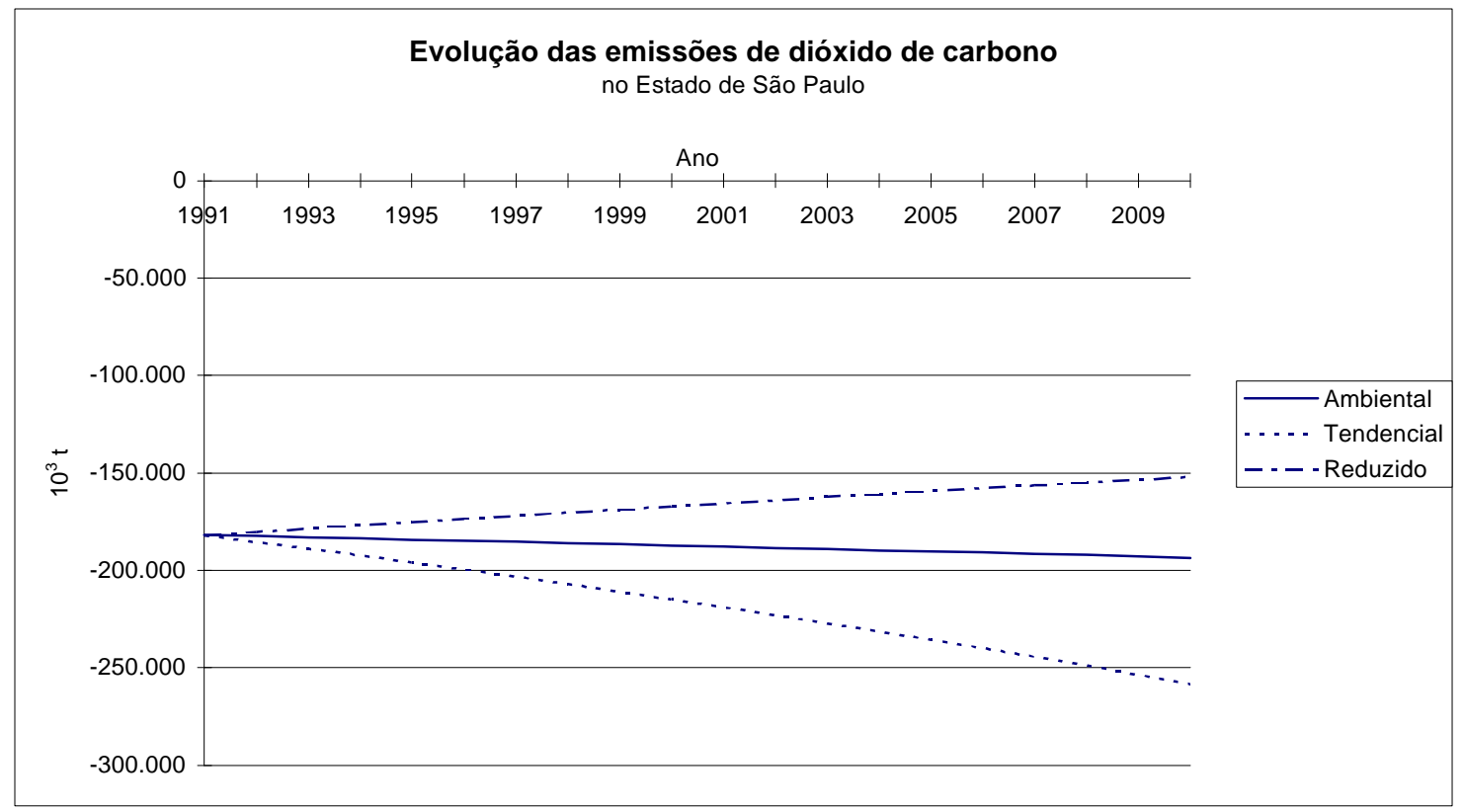

Fig. 4.9 Evolução das emissões de dióxido de carbono no Estado de São Paulo, em diversos cenários

O consumo de energia em cada cenário, mostrado nas tabelas 4.29 e 4.30, sofre variação proporcional à variação da produção. Os ganhos ou as perdas são decorrentes, essencialmente, da porcentagem de cana moída para produção de álcool nas usinas com destilaria anexa, uma vez que a distribuição da produção por nível tecnológico agrícola e industrial e a porcentagem de usinas com destilaria anexa é igual para todos os cenários.

TABELA 4.29 Consumo de energia no processo energético da cana-de-açúcar e seus derivados no Estado de São Paulo em 2010, [10³ GJ]

\begin{tabular}{lrrrr}
\hline \multicolumn{1}{c}{ Energia } & Ano base & \multicolumn{3}{c}{ Cenários para 2010 } \\
& 1991 & Ambiental & Tendencial & Reduzido \\
\hline Consumida & 25.853 & 29.396 & 37.070 & 21.212 \\
Produzida & 416.240 & 502.073 & 593.674 & 277.908 \\
Produção/insumo & 16,1 & 17,1 & 16,0 & 13,1 \\
\hline
\end{tabular}


A relação produção/consumo de insumo, que já era favorável no ano base, continua favorável nos cenários para 2010. No cenário ambiental é obtido um ganho de $6 \%$ em relação ao ano base, no reduzido a relação produção/consumo continua alta mas sofre uma redução de $19 \%$ em relação ao valor do ano base e no cenário tendencial a relação não sofre alteração apesar dos ganhos previstos na produtividade agrícola e industrial.

Para se obter um ganho ainda maior na relação produção/consumo, os índices de consumo de insumo que alimentam o modelo cascata devem ser melhorados. Para a elaboração dos cenários, os coeficientes de consumo de insumo energético são iguais aos do ano base.

TABELA 4.30 Variação porcentual do consumo de energia no processo energético da cana-de-açúcar no Estado de São Paulo em 2010, comparado ao ano base [\%]

\begin{tabular}{lrrr}
\hline \multicolumn{1}{c}{ Energia } & \multicolumn{3}{c}{ Cenários para 2010} \\
& Ambiental & Tendencial & Reduzido \\
\hline Consumida & 14 & 43 & -18 \\
Produzida & 21 & 43 & -33 \\
Produção/insumo & 6 & 0 & -19 \\
\hline
\end{tabular}

As estimativas dos custos de produção dos derivados de cana obtidos nos 3 cenários são mostrados na tabela 4.31 .

TABELA 4.31 Custo de produção dos derivados de cana-de-açúcar no Estado de São Paulo em 2010, [10 US\$]

\begin{tabular}{ccccc}
\hline Custo & Ano base & \multicolumn{3}{c}{ Cenários para 2010 } \\
& 1991 & Ambiental & Tendencial & Reduzido \\
\hline Total & 816 & 946 & 1.139 & 588 \\
\hline
\end{tabular}

A variação porcentual dos custos em 2010 comparados ao ano base, tabela 4.32, também é proporcional ao aumento da produção de cana-de-açúcar e seus 
derivados no mesmo período, mostrado nas tabelas 4.25 e 4.26. O que determina a diferença entre as variações porcentuais é a distribuição da produção entre açúcar e álcool. No cenário ambiental a produção de álcool etílico cresceu 36\% e o custo $16 \%$ em relação ao ano base, isto se deve basicamente a quantidade de cana moída para produção de álcool. Nos outros dois cenários os valores obtidos são: aumento de $44 \%$ na produção de álcool etílico e $40 \%$ nos custos, no cenário tendencial e redução de $43 \%$ na produção de álcool etílico e de $28 \%$ nos custos, no cenário reduzido. Os ganhos e perdas nestes cenários são, também, devido a quantidade de cana moída para produção de álcool etílico.

TABELA 4.32 Variação porcentual do custo de produção dos derivados de canade-açúcar no Estado de São Paulo em 2010, comparado ao ano base [\%]

\begin{tabular}{cccc}
\hline Custo & \multicolumn{3}{c}{ Cenários para 2010 } \\
& Ambiental & Tendencial & Reduzido \\
\hline Total & 16 & 40 & -28 \\
\hline
\end{tabular}

Os custos de produção de cana-de-açúcar e seus derivados podem ser reduzidos ainda mais se os coeficientes de impacto considerados fossem melhorados, considerando os ganhos obtidos na produtividade agrícola e industrial. Os coeficientes de custos considerados nos cenários são os mesmos calculados para o ano base. 


\section{CONCLUSÕES E RECOMENDAÇÕES}

Diante da dimensão dos problemas de impacto ambiental provocados pelo uso crescente de energia é que buscou-se elaborar um trabalho que fornecesse resultados que auxiliassem na elucidação de problemas relativos à produção e ao consumo de energia e seus impactos sobre o meio ambiente.

A redução dos problemas causados pela produção e consumo de energia passa pelo planejamento racional das necessidades reais de energia e seus impactos associados. Nesta década não dá para se imaginar a instalação de plantas energéticas sem que todas as variáveis que a envolvem: ambientais, sociais, econômicas e energéticas não sejam consideradas preliminarmente. Como vimos, no Brasil o planejamento energético é realizado pelos setores, basicamente, elétrico e petróleo. Um planejamento que integre as necessidades energéticas, tão necessário neste momento, é incipiente e necessita de iniciativas que estimulem a sua elaboração.

O levantamento bibliográfico dos modelos de energia mostra que existem várias ferramentas que podem ser utilizadas para a elaboração de um planejamento energético integrado, mas infelizmente foram poucos os modelos encontrados que relacionam energia e meio ambiente, ou ainda que considerassem todos os estágios do processo de conversão de energia. Estes modelos poderiam fornecer indicadores e simular cenários tendo em vista as alterações que vêm ocorrendo devido a utilização intensa de energia.

Os modelos em geral focam sua atenção a uma fonte de energia, ou a uma tecnologia ou ainda a um tipo de impacto. Há necessidade de se desenvolver ou melhorar modelos que integrem as diferentes áreas do conhecimento e que permitam uma visão global, porém não superficial, do problema.

O modelo cascata se apresenta como uma destas poucas ferramentas que possibilitam uma visão macro, mas de forma nenhuma descarta a utilização de outros modelos, os quais alimentam os cenários na elaboração de projeções. 


\subsection{O planejamento utilizando o modelo cascata}

O modela cascata, como pode ser visto no estudo de caso, é bastante versátil e utilizado com outros modelos apresenta algumas vantagens relacionadas por FERREIRA, 1989b e ratificadas por ARAÚJO, 1988. É um modelo de simples entendimento, direto e de fácil manutenção, leva em consideração a regionalização e, ainda, interage com o meio ambiente.

O modelo cascata, além da articulação regional, possui ainda uma desagregação por tipo de processo de produção, isto permite ligá-lo a outros modelos setoriais, o que torna a sua utilização mais vantajosa.

Utilizando o modelo cascata, o planejador pode interferir no processo pontualmente, segundo a sua necessidade. As conseqüências da sua atuação podem ser checadas e avaliadas antes de se tomar a decisão, isto pode ser útil para:

- melhorar a eficiência dos investimentos em novos sistemas energéticos, pois ajuda a evitar conflitos nas estratégias de investimentos;

- fornecer análises prospectivas a serem utilizadas em discussões públicas sobre sistemas de energia e problemas ambientais;

- demonstrar que não há conflitos entre objetivos de crescimento econômico, proteção ambiental e conservação de energia;

- orientar discussões estreitas a respeito de um específico poluente na direção de uma discussão abrangente sobre impactos ambientais em todos os estágios do processo de conversão de energia.

Como já visto não existe concepção ótima de modelo e como não poderia deixar de ser o modelo cascata também possui limites:

- perda de informações, devido ser uma representação contábil de uma realidade complexa e dinâmica;

- necessidade de outros modelos e submodelos que forneçam dados de entrada, projeções e variáveis contextuais, pois por mais detalhado que seja, o modelo cascata não apresenta todas as informações necessárias ao cálculo da matriz energética e ambiental; 
- disponibilidade de dados é outro fator, ainda que externo, de limitação do modelo. Alguns setores carecem de dados sistematizados, ainda mais quando se considera a tecnologia utilizada no processo;

- necessidade de estimativas, aproximações que podem comprometer a confiabilidade dos dados, caso não se tome o cuidado de explicitá-las, em virtude da dificuldade de obtenção de informações.

Para suprir a necessidade de dados é fundamental a constituição de um sistema integrado de informações que subsidiasse 0 planejador na alimentação do seu modelo, não só o modelo cascata que é intensivo em dados, como outros.

O planejador também deve utilizar, desde que disponíveis, modelos distintos pois eles podem apresentar versões complementares de um problema.

Temos consciência de que não há o melhor modelo, mas sim aquele que melhor serve a suas necessidades num determinado momento (ARAÚJO, 1988).

\subsection{O estudo de caso}

No estudo de caso pode-se verificar a aplicabilidade do modelo cascata; sem dúvida trata-se de uma ferramenta poderosa que, utilizada juntamente com outros modelos, pode auxiliar muito na tomada de decisões.

O estudo de caso, apesar de utilizar um modelo integrado, trabalha apenas com uma fonte de energia, o que dificulta as conclusões a serem tiradas. É conveniente para uma melhor representação dos fluxos de energia e impactos que o estudo feito para a cana-de-açúcar e seus derivados seja estendido a outros fluxos de energia e impactos que compõe o sistema energético. Num primeiro momento a aplicação do modelo cascata ao setor petróleo e seus derivados é interessante e permite obter uma série de conclusões e comparações.

A análise dos resultados da aplicação do modelo cascata para os produtos energéticos da cana-de-açúcar foi simplificada, pois é fácil identificar as principais fontes de impacto e conseqüentemente atuar sobre elas. 
Os diversos coeficientes e informações gerados neste trabalho também poderão ser úteis para alimentar outros modelos, o que permitirá obter uma outra versão do problema.

Analisando os resultados dos cenários propostos utilizando o modelo cascata pode-se concluir que:

- apesar dos extremos em que foram propostos, o futuro do setor sucroalcooleiro pode passar entre eles e para verificar se isto ocorrerá é interessante manter as informações atualizadas e corrigir os rumos sempre que necessário;

- os valores de emissão, apesar do crescimento da produção de cana e álcool, diminuem para quase todos os poluentes; os que aumentam, aumentam em taxas menores do que as de produção.

A emissão de aldeídos, no cenário ambiental, deve ser alvo de atenção pois não é considerada nenhuma melhoria tecnológica que diminuísse as emissões nos veículos a álcool em 2010, apesar deste uso ser a principal fonte de emissão de aldeídos;

A emissão de $\mathrm{CO}, \mathrm{HC}$ e MP pode ser significativamente reduzida se a colheita for mecanizada. Porém, não podem ser esquecidos os impactos sobre a socioeconomia provocados pela dispensa da mão-de-obra responsável pela colheita, uma vez que cada máquina pode substituir até 50 trabalhadores rurais (KOLLER, 1993).

- a relação consumo de energia/produção de energia é favorável em todos os cenários e depende fundamentalmente da melhoria dos rendimentos agrícola e industrial, mas principalmente do industrial;

- os custos obtidos nos cenários também variam em função da produtividade agrícola e industrial, portanto os valores podem ser reduzidos se forem melhorados os coeficientes de impacto que alimentam o modelo.

Os resultados do modelo e dos cenários estão disponíveis e, sem dúvida alguma, uma revisão crítica e aprimoramentos no método são bem-vindos a fim de que os resultados obtidos permitam sempre uma representação e avaliação realista dos cenários propostos. 


\section{Anexo A - Rendimento agrícola e industrial}

Este anexo é dividido em duas partes, na primeira, as usinas e destilarias são classificadas em função do rendimento agrícola e na segunda, em função dos rendimentos industriais. Isto é feito buscando a formação de grupos que representem o nível tecnológico agrícola e industrial das unidades produtivas. As usinas e destilarias reunidas em grupos homogêneos, fazem parte de um universo de 134 unidades produtivas do Estado de São Paulo que constavam do inventário elaborado pelo Conselho de administração das empresas de energia do Estado de São Paulo.

\section{A.1 Rendimento agrícola}

A tabela A.1 fornece a produção de cana e a área de corte, para a safra de 91/92, de 117 usinas e destilarias do Estado de São Paulo. O rendimento agrícola de cada unidade foi calculado através do quociente da quantidade de cana produzida em toneladas pela área de corte em hectares.

A partir dos valores de rendimento agrícola, as usinas e destilarias foram agrupadas, na tabela A.2, em faixas de rendimento com as quais elaborou-se um histograma, figura A.1.

Os níveis tecnológicos de produção agrícola, que são utilizados no modelo, capítulo 3, tabela 3.1, são definidos através da análise criteriosa da figura A.1.

TABELA A.1 Produção de cana-de-açúcar e rendimento agrícola de usinas e destilarias no Estado de São Paulo, safra 91/92

\begin{tabular}{rcrr}
\hline Usina & $\begin{array}{c}\text { Produção de } \\
\text { cana total } \\
\text { [tC] }\end{array}$ & $\begin{array}{c}\text { Área de } \\
\text { Corte } \\
\text { [ha] }\end{array}$ & $\begin{array}{r}\text { Rendimento } \\
\text { Agrícola } \\
\text { [tC/ha] }\end{array}$ \\
\hline 1 & 425.596 & 5.097 & 83,50 \\
2 & 301.797 & 4.366 & 69,12 \\
3 & 833.112 & 9.994 & 83,36 \\
5 & 725.722 & 9.110 & 79,66 \\
6 & 493.093 & 6.200 & 79,53
\end{tabular}




\begin{tabular}{|c|c|c|c|}
\hline Usina & $\begin{array}{c}\text { Produção de } \\
\text { cana total } \\
{[\mathrm{tC}]}\end{array}$ & $\begin{array}{c}\text { Área de } \\
\text { Corte } \\
\text { [ha] }\end{array}$ & $\begin{array}{c}\text { Rendimento } \\
\text { Agrícola } \\
\text { [tC/ha] }\end{array}$ \\
\hline 7 & 465.595 & 6.110 & 76,20 \\
\hline 8 & 182.264 & 2.095 & 87,00 \\
\hline 9 & 824.389 & 8.617 & 95,67 \\
\hline 10 & 1.326 .595 & 17.561 & 75,54 \\
\hline 11 & 1.836 .892 & 19.009 & 96,63 \\
\hline 13 & 121.005 & 1.583 & 76,44 \\
\hline 16 & 1.194 .193 & 16.021 & 74,54 \\
\hline 17 & 39.349 & 850 & 46,29 \\
\hline 18 & 845.620 & 8.795 & 96,15 \\
\hline 19 & 398.150 & 4.349 & 91,55 \\
\hline 20 & 745.271 & 9.324 & 79,93 \\
\hline 21 & 3.264 .950 & 35.733 & 91,37 \\
\hline 22 & 1.314 .042 & 19.675 & 66,79 \\
\hline 23 & 2.373 .194 & 29.124 & 81,49 \\
\hline 24 & 373.374 & 7.282 & 51,27 \\
\hline 25 & 516.665 & 6.391 & 80,84 \\
\hline 26 & 761.432 & 11.848 & 64,27 \\
\hline 27 & 404.934 & 4.251 & 95,26 \\
\hline 28 & 686.349 & 10.040 & 68,36 \\
\hline 29 & 1.399 .878 & 15.396 & 90,92 \\
\hline 31 & 2.729.211 & 33.695 & 81,00 \\
\hline 33 & 853.763 & 9.875 & 86,46 \\
\hline 34 & 1.174 .861 & 12.688 & 92,60 \\
\hline 35 & 7.027 .870 & 76.145 & 92,30 \\
\hline 36 & 2.743 .872 & 32.087 & 85,51 \\
\hline 37 & 1.018 .362 & 13.816 & 73,71 \\
\hline 38 & 397.993 & 5.633 & 70,65 \\
\hline 39 & 205.008 & 3.328 & 61,60 \\
\hline 40 & 309.815 & 5.635 & 54,98 \\
\hline 41 & 177.179 & 2070 & 85,59 \\
\hline 42 & 131.358 & 2019 & 65,06 \\
\hline 43 & 436.577 & 5212 & 83,76 \\
\hline 44 & 1.506 .049 & 18.190 & 82,80 \\
\hline 45 & 2.048 .254 & 24.233 & 84,52 \\
\hline 46 & 1.158 .000 & 15.900 & 72,83 \\
\hline 47 & 212.000 & 3.630 & 58,40 \\
\hline 48 & 818.104 & 11.100 & 73,70 \\
\hline 49 & 1.076 .212 & 14.045 & 76,63 \\
\hline 50 & 413.091 & 4.746 & 87,04 \\
\hline
\end{tabular}




\begin{tabular}{|c|c|c|c|}
\hline Usina & $\begin{array}{c}\text { Produção de } \\
\text { cana total } \\
{[\mathrm{tC}]}\end{array}$ & $\begin{array}{c}\text { Área de } \\
\text { Corte } \\
\text { [ha] }\end{array}$ & $\begin{array}{c}\text { Rendimento } \\
\text { Agrícola } \\
\text { [tC/ha] }\end{array}$ \\
\hline 52 & 881.257 & 9.512 & 92,65 \\
\hline 53 & 380.788 & 4.916 & 77,46 \\
\hline 54 & 522.684 & 6.701 & 78,00 \\
\hline 55 & 431.002 & 6.012 & 71,69 \\
\hline 57 & 613.890 & 6.921 & 88,70 \\
\hline 58 & 1.649 .993 & 19.702 & 83,75 \\
\hline 59 & 520.130 & 6.540 & 79,53 \\
\hline 60 & 90.616 & 2.688 & 33,71 \\
\hline 61 & 300.000 & 3.637 & 82,49 \\
\hline 62 & 94.667 & 1.332 & 71,07 \\
\hline 63 & 139.624 & 2.966 & 47,07 \\
\hline 65 & 1.043 .779 & 12.941 & 80,66 \\
\hline 66 & 1.478 .295 & 15.277 & 96,77 \\
\hline 67 & 1.111 .000 & 12.957 & 85,75 \\
\hline 68 & 819.471 & 11.210 & 73,10 \\
\hline 69 & 851.814 & 10.784 & 78,99 \\
\hline 70 & 1.134 .542 & 16.568 & 68,48 \\
\hline 71 & 996.022 & 14.605 & 68,20 \\
\hline 72 & 1.369 .186 & 15.587 & 87,84 \\
\hline 73 & 920.085 & 10.937 & 84,13 \\
\hline 74 & 2.348 .673 & 29.335 & 80,06 \\
\hline 75 & 268.568 & 3.414 & 78,67 \\
\hline 76 & 348.529 & 5.479 & 63,61 \\
\hline 77 & 301.034 & 3.836 & 78,48 \\
\hline 78 & 504.756 & 7.212 & 69,99 \\
\hline 79 & 430.439 & 6.175 & 69,71 \\
\hline 80 & 311.505 & 4.451 & 69,99 \\
\hline 82 & 368.046 & 4.873 & 75,53 \\
\hline 83 & 594.347 & 6.699 & 88,72 \\
\hline 84 & 175.168 & 1.973 & 88,78 \\
\hline 87 & 1.759 .975 & 25.281 & 69,62 \\
\hline 88 & 1.063 .068 & 13.442 & 79,09 \\
\hline 89 & 1.678 .339 & 17.947 & 93,52 \\
\hline 90 & 634.931 & 7.637 & 83,14 \\
\hline 91 & 155.198 & 1.891 & 82,07 \\
\hline 92 & 1.514 .631 & 17.242 & 87,85 \\
\hline 94 & 1.640 .259 & 19.570 & 83,81 \\
\hline 95 & 2.982 .936 & 38.499 & 77,48 \\
\hline 96 & 1.034 .365 & 13.305 & 77,74 \\
\hline
\end{tabular}




\begin{tabular}{rrrr}
\hline Usina & $\begin{array}{r}\text { Produção de } \\
\text { cana total }\end{array}$ & $\begin{array}{c}\text { Área de } \\
\text { Corte }\end{array}$ & $\begin{array}{c}\text { Rendimento } \\
\text { Agrícola }\end{array}$ \\
\hline & \multicolumn{1}{c}{ [C] } & \multicolumn{1}{c}{ ha] } & \multicolumn{1}{c}{ [tC/ha] } \\
\hline 97 & 979.547 & 12.558 & 78,00 \\
98 & 3.427 .419 & 38.779 & 88,38 \\
99 & 904.505 & 9.138 & 98,98 \\
100 & 83.550 & 1.470 & 56,84 \\
101 & 1.001 .244 & 12.515 & 80,00 \\
102 & 1.004 .536 & 11.086 & 90,61 \\
103 & 1.358 .080 & 15.314 & 88,68 \\
104 & 63.192 & 1.337 & 47,26 \\
105 & 1.204 .503 & 18.137 & 66,41 \\
106 & 255.074 & 3.110 & 82,02 \\
107 & 352.000 & 4.340 & 81,11 \\
108 & 3.033 .240 & 38.181 & 79,44 \\
109 & 723.850 & 8.406 & 86,11 \\
111 & 509.280 & 6.050 & 84,18 \\
113 & 719.920 & 7.746 & 92,94 \\
114 & 1.565 .402 & 16.174 & 96,79 \\
115 & 1.497 .000 & 16.970 & 88,21 \\
116 & 956.754 & 12.328 & 77,61 \\
117 & 1.017 .376 & 12.646 & 80,45 \\
118 & 1.241 .863 & 15.125 & 82,11 \\
119 & 957.305 & 10.734 & 89,18 \\
120 & 299.075 & 3.754 & 79,67 \\
121 & 5.054 .497 & 60.228 & 83,92 \\
123 & 608.554 & 8.145 & 74,72 \\
125 & 1.230 .620 & 15.596 & 78,91 \\
126 & 1.191 .054 & 13.623 & 87,43 \\
127 & 516.205 & 5.478 & 94,23 \\
128 & 1.038 .986 & 11.911 & 87,23 \\
129 & 432.501 & 4.984 & 86,78 \\
130 & 2.593 .971 & 33.674 & 77,03 \\
131 & 231.630 & 4.079 & 56,79 \\
132 & 643.817 & 7.016 & 91,76 \\
133 & 127.600 & 1.867 & 68,34 \\
134 & 1.165 .192 & 14.460 & 80,58 \\
\hline Total & 117.743 .994 & 1.439 .881 & \\
Média & & & 81,77 \\
\hline & & &
\end{tabular}

Fonte: MUNHOZ (1993).

Nota: As usinas que não aparecem na lista não forneceram as informações. 
TABELA A.2 Distribuição de usinas por rendimento agrícola

\begin{tabular}{cc}
\hline Faixa de rendimento agrícola [tC/ha] & Quantidade de usinas \\
\hline $30,00-34,99$ & 1 \\
$35,00-39,99$ & 0 \\
$40,00-44,99$ & 0 \\
$45,00-49,99$ & 3 \\
$50,00-54,99$ & 2 \\
$55,00-59,99$ & 3 \\
$60,00-64,99$ & 3 \\
$65,00-69,99$ & 12 \\
$70,00-74,99$ & 9 \\
$75,00-79,99$ & 23 \\
$80,00-84,99$ & 24 \\
$85,00-89,99$ & 19 \\
$90,00-94,99$ & 11 \\
$95,00-99,99$ & 7 \\
acima de 100 & 0 \\
\hline
\end{tabular}

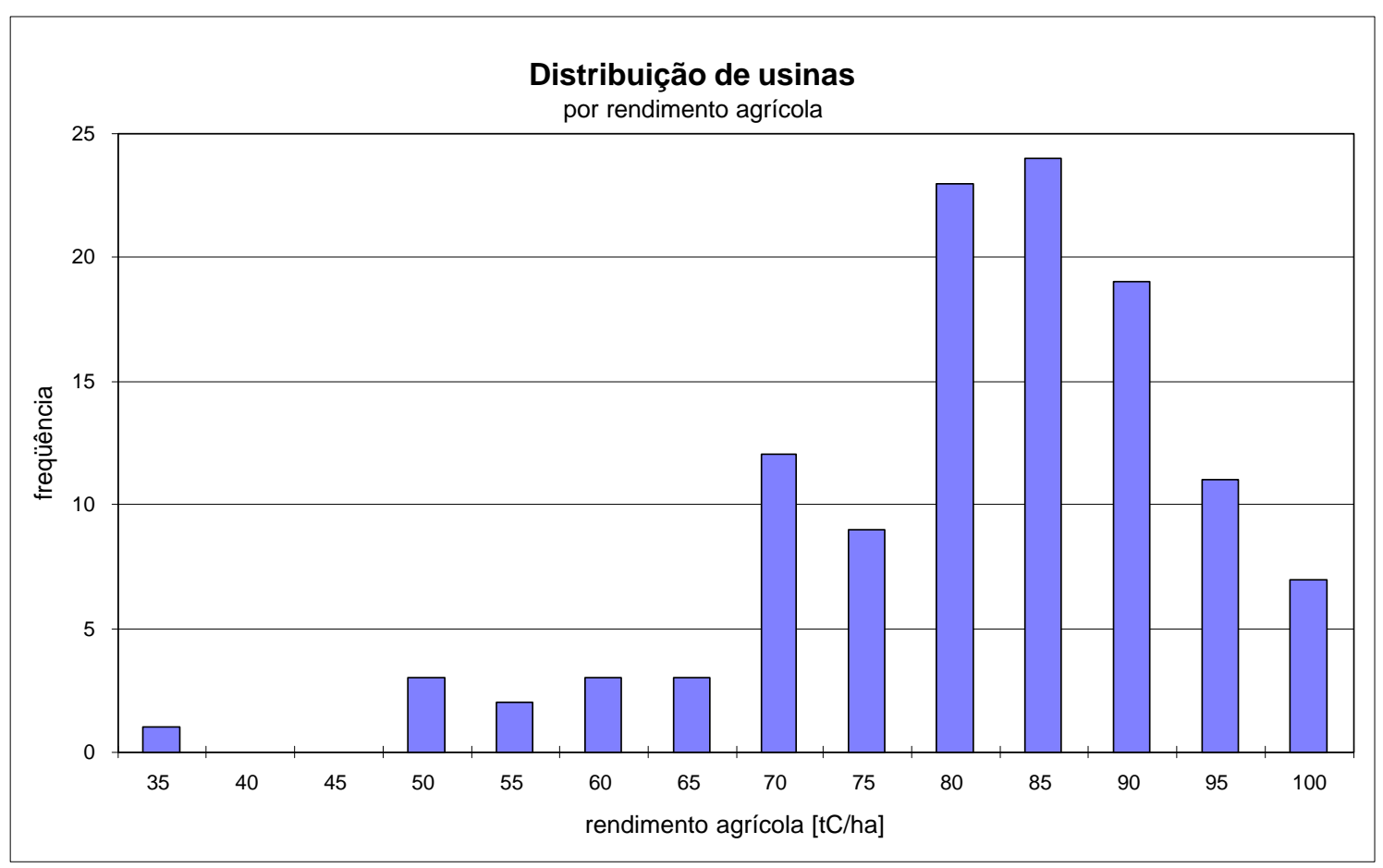

Fig. A.1 Distribuição de usinas por rendimento agrícola 


\section{A.2 Rendimento industrial}

O rendimento industrial de usinas e destilarias é obtido através da divisão da produção de açúcar ou álcool pela quantidade de cana processada (moída). Os valores obtidos para 108 usinas e destilarias, são distribuídos conforme o tipo de instalação, nas tabelas A.3, A.5 e A.7.

TABELA A.3 Rendimento industrial de usinas de açúcar no Estado de São Paulo, safra 91/92

\begin{tabular}{rrrr}
\hline $\begin{array}{r}\text { Usina Produção } \\
\text { de açúcar } \\
{[\mathrm{t}]}\end{array}$ & $\begin{array}{r}\text { Cana moída } \\
\text { para açúcar } \\
{[\mathrm{tC}]}\end{array}$ & $\begin{array}{c}\text { Rendimento } \\
\text { industrial } \\
{[\mathrm{kg} / \mathrm{tC}]}\end{array}$ \\
\hline 34 & 117.807 & 1.174 .839 & 100,27 \\
56 & 39.790 & 429.742 & 92,59 \\
63 & 12.923 & 139.624 & 92,56 \\
101 & 88.971 & 1.001 .244 & 88,86 \\
124 & 41.205 & 438.435 & 93,98 \\
\hline Total & 300.696 & 3.183 .884 & \\
Média & & & 94,44 \\
\hline
\end{tabular}

Fonte: MUNHOZ (1993).

TABELA A.4 Distribuição de usinas de açúcar por rendimento industrial

\begin{tabular}{|c|c|}
\hline Faixa de rendimento industrial $[\mathrm{kg} / \mathrm{tC}]$ & Quantidade de usinas \\
\hline $80,00-84,99$ & 0 \\
\hline $85,00-89,99$ & 1 \\
\hline $90,00-94,99$ & 3 \\
\hline $95,00-99,99$ & 0 \\
\hline $100,00-104,9$ & 1 \\
\hline acima de 105 & 0 \\
\hline Total & 5 \\
\hline
\end{tabular}

Da mesma forma como é feito na etapa de produção agrícola, os rendimentos industriais são distribuídos em faixas por tipo de instalação. A distribuição em faixas é mostrada na tabela A.4 para usinas de açúcar; na tabela A.6 para usinas de açúcar com destilaria anexa e na tabela A.8 para destilarias 
autônomas. Os histogramas obtidos a partir destas tabelas são mostrados nas figuras A.2, A.3, A.4 e A.5, e foram analisados buscando agrupar as usinas com coeficientes técnicos semelhantes.

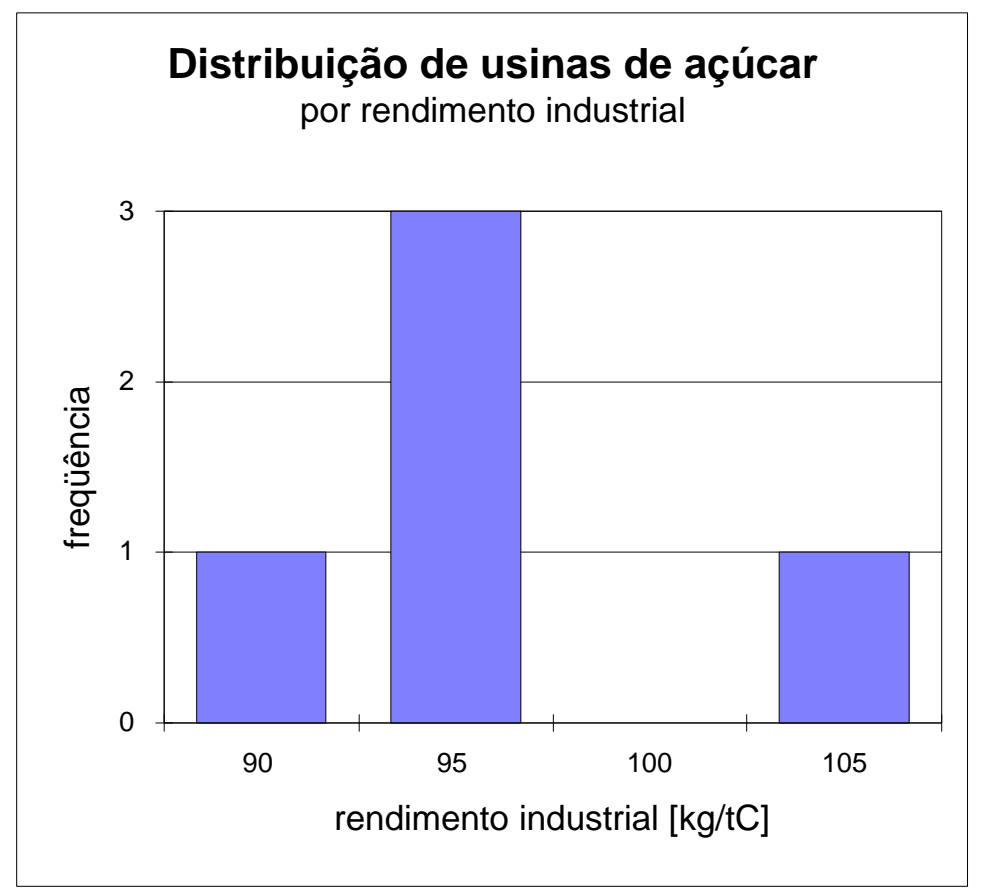

Fig. A.2 Distribuição de usinas de açúcar por rendimento industrial

TABELA A.5 Rendimento industrial de usinas de açúcar, com destilaria em anexo, no Estado de São Paulo, safra 91/92

\begin{tabular}{|c|c|c|c|c|c|c|}
\hline Usina & $\begin{array}{l}\text { Produção } \\
\text { de açúcar }\end{array}$ & $\begin{array}{c}\text { Cana } \\
\text { moída para } \\
\text { açúcar } \\
\text { [tC] }\end{array}$ & $\begin{array}{c}\text { Rendimento } \\
\text { industrial do } \\
\text { açúcar } \\
\text { [kg/tC] }\end{array}$ & $\begin{array}{c}\text { Produção } \\
\text { de álcool } \\
\text { etílico } \\
{\left[\mathrm{m}^{3}\right]}\end{array}$ & $\begin{array}{c}\text { Cana } \\
\text { moída para } \\
\text { álcool } \\
{[\mathrm{tC}]}\end{array}$ & $\begin{array}{c}\text { Rendimento } \\
\text { industrial do } \\
\text { álcool } \\
{[\mathrm{la} / \mathrm{tC}]}\end{array}$ \\
\hline 3 & 38.824 & 334.663 & 116,01 & 45.500 & 498.449 & 91,28 \\
\hline 10 & 53.120 & 470.338 & 112,94 & 51.410 & 565.701 & 90,88 \\
\hline 18 & 42.313 & 341.852 & 123,78 & 48.163 & 503.768 & 95,61 \\
\hline 20 & 30.401 & 240.021 & 126,66 & 40.850 & 505.250 & 80,85 \\
\hline 22 & 67.668 & 571.716 & 118,36 & 59.647 & 742.326 & 80,35 \\
\hline 23 & 77.855 & 597.208 & 130,36 & 165.960 & 1.775 .986 & 93,45 \\
\hline 24 & 13.630 & 127.395 & 106,99 & 20.080 & 245.979 & 81,63 \\
\hline 26 & 15.410 & 137.564 & 112,02 & 47.848 & 623.868 & 76,70 \\
\hline
\end{tabular}




\begin{tabular}{|c|c|c|c|c|c|c|}
\hline Usina & $\begin{array}{c}\text { Produção } \\
\text { de açúcar } \\
\text { [t] }\end{array}$ & $\begin{array}{c}\text { Cana } \\
\text { moída para } \\
\text { açúcar } \\
{[\mathrm{tC}]}\end{array}$ & $\begin{array}{c}\text { Rendimento } \\
\text { industrial do } \\
\text { açúcar } \\
{[\mathrm{kg} / \mathrm{tC}]}\end{array}$ & $\begin{array}{c}\text { Produção } \\
\text { de álcool } \\
\text { etílico } \\
{\left[\mathrm{m}^{3}\right]}\end{array}$ & $\begin{array}{c}\text { Cana } \\
\text { moída para } \\
\text { álcool } \\
\text { [tC] }\end{array}$ & $\begin{array}{c}\text { Rendimento } \\
\text { industrial do } \\
\text { álcool } \\
{[\mathrm{la} / \mathrm{tC}]}\end{array}$ \\
\hline 31 & 101.750 & 891.882 & 114,08 & 3158.660 & 1.837 .329 & 86,35 \\
\hline 36 & 134.076 & 1.150 .854 & 116,50 & 160.643 & 1.593 .018 & 100,84 \\
\hline 37 & 50.470 & 516.560 & 97,70 & 49.129 & 501.802 & 97,91 \\
\hline 44 & 40.500 & 378.883 & 106,89 & 95.000 & 1.127 .166 & 84,28 \\
\hline 48 & 39.515 & 383.294 & 103,09 & 36.320 & 434.810 & 83,53 \\
\hline 55 & 8.221 & 73.041 & 112,55 & 27.690 & 357.960 & 77,36 \\
\hline 58 & 31.250 & 315.149 & 99,16 & 116.600 & 1.285 .271 & 90,72 \\
\hline 65 & 51.091 & 400.602 & 127,54 & 56.707 & 643.177 & 88,17 \\
\hline 67 & 23.500 & 173.170 & 135,70 & 82.529 & 937.830 & 88,00 \\
\hline 69 & 21.640 & 179.435 & 120,60 & 63.461 & 672.380 & 94,38 \\
\hline 72 & 58.706 & 446.983 & 131,34 & 82.100 & 922.203 & 89,03 \\
\hline 74 & 85.500 & 814.291 & 105,00 & 148.550 & 1.534 .382 & 96,81 \\
\hline 79 & 17.240 & 126.073 & 136,75 & 28.212 & 304.366 & 92,69 \\
\hline 87 & 78.816 & 697.486 & 113,00 & 64.000 & 849.558 & 75,33 \\
\hline 88 & 45.861 & 476.766 & 96,19 & 46.400 & 586.302 & 79,14 \\
\hline 89 & 53.223 & 384.889 & 138,28 & 130.309 & 1.293 .450 & 100,75 \\
\hline 90 & 16.911 & 143.322 & 117,99 & 47.547 & 491.609 & 96,72 \\
\hline 95 & 101.581 & 858.490 & 118,33 & 189.000 & 2.124.146 & 88,98 \\
\hline 96 & 47.909 & 437.304 & 109,56 & 50.318 & 597.061 & 84,28 \\
\hline 97 & 31.843 & 287.477 & 110,77 & 62.330 & 692.070 & 90,06 \\
\hline 98 & 202.213 & 1.674 .630 & 120,75 & 227.576 & 2.447 .957 & 92,97 \\
\hline 99 & 29.110 & 208.000 & 139,95 & 43.350 & 586.505 & 73,91 \\
\hline 103 & 74.458 & 638.012 & 116,70 & 68.128 & 720.068 & 94,61 \\
\hline 105 & 49.331 & 455.177 & 108,38 & 42.400 & 749.326 & 56,58 \\
\hline 108 & 109.000 & 933.621 & 116,75 & 203.002 & 2.260 .974 & 89,79 \\
\hline 111 & 15.000 & 138.405 & 108,38 & 20.000 & 370.875 & 53,93 \\
\hline 113 & 30.000 & 250.000 & 120,00 & 41.400 & 469.920 & 88,10 \\
\hline 114 & 64.183 & 619.196 & 103,66 & 71.572 & 946.206 & 75,64 \\
\hline 116 & 52.903 & 412.553 & 128,23 & 45.950 & 544.201 & 84,44 \\
\hline 117 & 47.983 & 407.279 & 117,81 & 54.902 & 610.097 & 89,99 \\
\hline 119 & 30.680 & 289.195 & 106,09 & 53.210 & 668.110 & 79,64 \\
\hline 121 & 229.550 & 1.911 .170 & 120,11 & 292.000 & 3.143.327 & 92,90 \\
\hline 123 & 20.500 & 205.659 & 99,68 & 28.150 & 402.895 & 69,87 \\
\hline 130 & 95.000 & 831.816 & 114,21 & 167.227 & 1.779 .211 & 93,99 \\
\hline \multirow{2}{*}{\multicolumn{3}{|c|}{ Total 2.428 .73520 .931 .421}} & \multicolumn{4}{|c|}{3.533 .83039 .946 .889} \\
\hline & & & 116,03 & & & 88,46 \\
\hline
\end{tabular}

Fonte: MUNHOZ (1993). 
TABELA A.6 Distribuição de usinas de açúcar, com destilaria anexa, por rendimento industrial na produção de açúcar e álcool

\begin{tabular}{cc|cc}
\hline \multicolumn{2}{c|}{ Açúcar } & \multicolumn{2}{c}{ Álcool } \\
\hline $\begin{array}{c}\text { Faixa de } \\
\text { rendimento } \\
\text { industrial [kg/tC] }\end{array}$ & $\begin{array}{c}\text { Quantidade } \\
\text { de usinas }\end{array}$ & $\begin{array}{c}\text { Faixa de } \\
\text { rendimento } \\
\text { industrial [la/tC] }\end{array}$ & $\begin{array}{c}\text { Quantidade } \\
\text { de usinas }\end{array}$ \\
\hline $90,00-94,99$ & 0 & $45,00-49,99$ & 0 \\
$95,00-99,99$ & 4 & $50,00-54,99$ & 1 \\
$100,00-104,9$ & 3 & $55,00-59,99$ & 1 \\
$105,00-109,9$ & 6 & $60,00-64,99$ & 0 \\
$110,00-114,9$ & 7 & $65,00-69,99$ & 1 \\
$115,00-119,9$ & 9 & $70,00-74,99$ & 1 \\
$120,00-124,9$ & 4 & $75,00-79,99$ & 6 \\
$125,00-129,9$ & 3 & $80,00-84,99$ & 7 \\
$130,00-134,9$ & 2 & $85,00-89,99$ & 8 \\
$135,00-139,9$ & 4 & $90,00-94,99$ & 11 \\
acima de 140 & 0 & $95,00-99,99$ & 4 \\
& & $100,00-104,99$ & 2 \\
& & & \\
\hline Total & 42 & & 42 \\
\hline
\end{tabular}



Fig. A.3 Distribuição de usinas de açúcar com destilaria anexa por rendimento industrial na produção de açúcar 


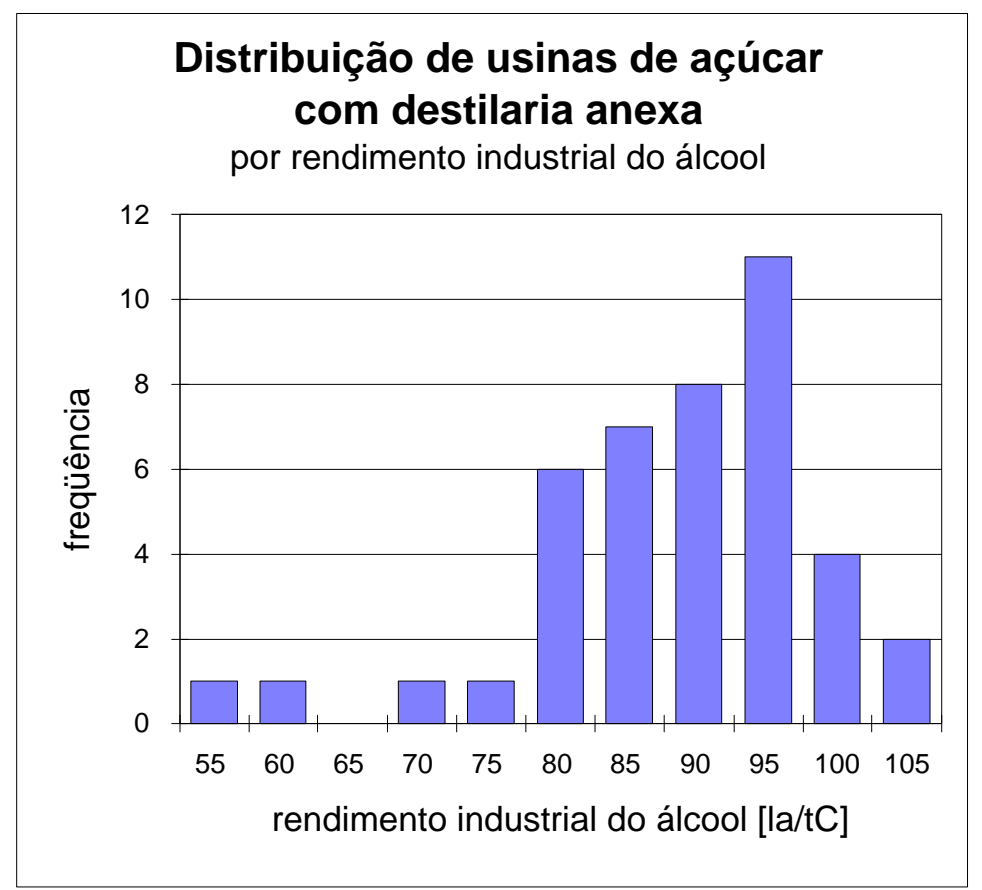

Fig. A.4 Distribuição de usinas de açúcar com destilaria anexa por rendimento industrial na produção de álcool

TABELA A.7 Rendimento industrial de destilarias autônomas no Estado de São Paulo, safra 91/92

\begin{tabular}{rrrr}
\hline $\begin{array}{c}\text { Usina Produção de Cana moída } \\
\text { álcool etílico } \\
{\left[\mathrm{m}^{3}\right]}\end{array}$ & $\begin{array}{c}\text { para álcool } \\
{[\mathrm{tC}]}\end{array}$ & $\begin{array}{c}\text { Rendimento } \\
\text { industrial do álcool } \\
{[\mathrm{la} / \mathrm{tC}]}\end{array}$ \\
\hline 1 & 34.704 & 425.596 & 81,54 \\
2 & 25.186 & 301.797 & 83,45 \\
4 & 63.444 & 713.396 & 88,93 \\
5 & 55.982 & 725.722 & 77,14 \\
6 & 42.151 & 493.093 & 85,48 \\
7 & 39.250 & 464.430 & 84,51 \\
8 & 15.137 & 182.264 & 83,05 \\
9 & 75.391 & 824.389 & 91,45 \\
11 & 157.525 & 1.836 .892 & 85,76 \\
12 & 43.489 & 497.953 & 87,34 \\
13 & 9.275 & 121.005 & 76,65 \\
15 & 42.024 & 473.390 & 88,77 \\
16 & 105.340 & 1.194 .193 & 88,21 \\
17 & 2.112 & 28.640 & 73,74
\end{tabular}




\begin{tabular}{|c|c|c|c|}
\hline Usina & $\begin{array}{c}\text { Produção de } \\
\text { álcool etílico } \\
{\left[\mathrm{m}^{3}\right]}\end{array}$ & $\begin{array}{c}\text { Cana moída } \\
\text { para álcool } \\
{[\mathrm{tC}]}\end{array}$ & $\begin{array}{c}\text { Rendimento } \\
\text { industrial do álcool } \\
{[\mathrm{la} / \mathrm{tC}]}\end{array}$ \\
\hline 19 & 33.801 & 398.150 & 84,90 \\
\hline 25 & 42.501 & 516.665 & 82,26 \\
\hline 27 & 32.000 & 404.934 & 79,03 \\
\hline 28 & 57.169 & 677.108 & 84,43 \\
\hline 29 & 116.669 & 1.314 .148 & 88,78 \\
\hline 38 & 30.939 & 375.308 & 82,44 \\
\hline 39 & 14.793 & 205.008 & 72,16 \\
\hline 40 & 24.833 & 306.751 & 80,95 \\
\hline 41 & 13.762 & 177.179 & 77,67 \\
\hline 42 & 11.084 & 150.740 & 73,53 \\
\hline 43 & 35.965 & 436.577 & 82,38 \\
\hline 45 & 155.623 & 2.048 .254 & 75,98 \\
\hline 47 & 16.000 & 212.000 & 75,47 \\
\hline 49 & 94.773 & 1.076 .212 & 88,06 \\
\hline 50 & 33.027 & 413.091 & 79,95 \\
\hline 51 & 65.358 & 816.512 & 80,05 \\
\hline 54 & 42.841 & 526.805 & 81,32 \\
\hline 57 & 56.857 & 613.890 & 92,62 \\
\hline 59 & 44.279 & 520.130 & 85,13 \\
\hline 60 & 6.115 & 90.616 & 67,48 \\
\hline 61 & 24.547 & 315.069 & 77,91 \\
\hline 62 & 6.767 & 94.667 & 71,48 \\
\hline 64 & 58.932 & 668.649 & 88,14 \\
\hline 70 & 96.444 & 1.134 .542 & 85,01 \\
\hline 73 & 81.510 & 920.085 & 88,59 \\
\hline 75 & 20.880 & 268.568 & 77,75 \\
\hline 77 & 21.506 & 301.034 & 71,44 \\
\hline 78 & 45.244 & 504.756 & 89,64 \\
\hline 80 & 23.285 & 311.505 & 74,75 \\
\hline 81 & 9.438 & 119.449 & 79,01 \\
\hline 82 & 31.421 & 368.046 & 85,37 \\
\hline 83 & 48.652 & 594.347 & 81,86 \\
\hline 85 & 12.424 & 147.392 & 84,29 \\
\hline 100 & 5.804 & 83.550 & 69,47 \\
\hline 104 & 4.125 & 63.192 & 65,28 \\
\hline 106 & 20.314 & 255.074 & 79,64 \\
\hline 107 & 29.000 & 352.000 & 82,39 \\
\hline 109 & 51.169 & 641.401 & 79,78 \\
\hline 120 & 21.563 & 299.075 & 72,10 \\
\hline
\end{tabular}




\begin{tabular}{crrc}
\hline $\begin{array}{r}\text { Usina Produção de Cana moída } \\
\text { álcool etílico } \\
{\left[\mathrm{m}^{3}\right]}\end{array}$ & $\begin{array}{c}\text { para álcool } \\
{[\mathrm{tC}]}\end{array}$ & $\begin{array}{c}\text { Rendimento } \\
\text { industrial do álcool } \\
{[\mathrm{la} / \mathrm{tC}]}\end{array}$ \\
\hline 125 & 88.533 & 1.230 .620 & 71,94 \\
126 & 77.242 & 906.685 & 85,19 \\
127 & 45.258 & 516.705 & 87,59 \\
128 & 90.690 & 1.038 .986 & 87,29 \\
129 & 38.173 & 432.501 & 88,26 \\
131 & 20.030 & 231.630 & 86,47 \\
132 & 51.800 & 643.817 & 80,46 \\
133 & 9.597 & 127.600 & 75,21 \\
\hline Total & 2.673 .747 & 32.133 .783 & \\
Média &. & & 83,21 \\
\hline
\end{tabular}

Fonte: MUNHOZ (1993).

TABELA A.8 Distribuição de destilarias autônomas por rendimento industrial

\begin{tabular}{|c|c|}
\hline Faixa de rendimento industrial [la/tC] & Quantidade de usinas \\
\hline $60,00-64,99$ & 0 \\
\hline $65,00-69,99$ & 3 \\
\hline $70,00-74,99$ & 8 \\
\hline $75,00-79,99$ & 13 \\
\hline $80,00-84,99$ & 16 \\
\hline $85,00-89,99$ & 19 \\
\hline $90,00-94,99$ & 2 \\
\hline acima de 95 & 0 \\
\hline Total & 61 \\
\hline
\end{tabular}




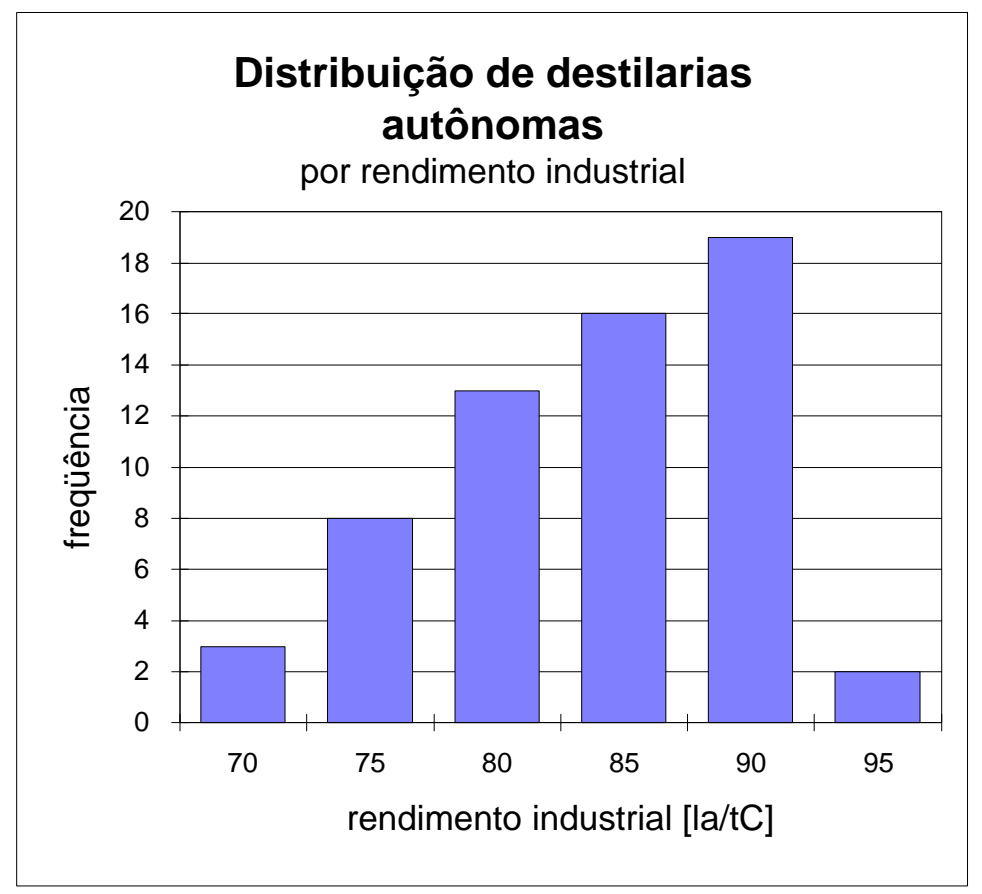

Fig. A.5 Distribuição de destilarias autônomas por rendimento industrial

Os grupos formados apresentam as seguintes características:

- unidades com nível tecnológico baixo: usinas de açúcar com produção até $105 \mathrm{~kg}$ de açúcar ou 75 litros de álcool por tonelada de cana moída. Destilarias autônomas que produzem até 75 litros de álcool por tonelada de cana.

- unidades com nível tecnológico médio: usinas de açúcar que produzem: mais de $105 \mathrm{~kg}$ de açúcar e entre 75 e 90 litros de álcool por tonelada de cana processada. Destilarias autônomas produzindo na faixa de 75 a 90 litros de álcool por tonelada de cana.

- unidades com nível tecnológico alto: destilarias autônomas e usinas de açúcar que produzem mais de 90 litros de álcool por tonelada de cana, e usinas de açúcar com produção acima de $105 \mathrm{~kg}$ de açúcar por tonelada de cana processada.

A distribuição de usinas e destilarias em níveis tecnológicos é mostrada no capítulo 3, tabela 3.11. 
A análise da estatística descritiva feita para as duas etapas resultou em algumas observações:

- existem unidades que não forneceram alguns dados, como por exemplo a área de corte, a quantidade de cana processada, e portanto não fazem parte das duas etapas do estudo.

- as informações sobre a destinação da cana para produção de açúcar ou de álcool são muito imprecisas. A precisão destas informações é comprometida pela dificuldade e a falta de instrumentos para medir a quantidade de caldo enviada àfabricação de açúcar ou de álcool;

- há usinas com informações totalmente distorcidas, provavelmente, devido a erros de transcrição ocorridos no processo de compilação dos dados;

- o total de cana processada, a área total cortada e a produção total de açúcar e álcool, apesar de não serem totalmente fiéis conforme informações do próprio Conselho de administração, são menos distorcidos. Isto tem como conseqüência uma qualidade aceitável dos rendimentos agrícolas e industriais médios calculados utilizando estes dados. 


\section{Anexo B - Consumo de energia}

O artigo "Balanço de energia na produção de cana-de-açúcar e álcool nas usinas cooperadas" é a referência utilizada no cálculo dos coeficientes de consumo de energia utilizados neste trabalho. MACEDO; NOGUEIRA (1985) calcularam o consumo de energia necessário àprodução de álcool em grandes blocos. Isto foi feito para todo o processo energético, desde a produção de cana-de-açúcar até a produção de álcool.

Apesar das restrições regionais e condições diferentes em cada unidade, MACEDO; NOGUEIRA (1985) analisaram duas situações: a primeira utilizando as médias de consumo de energia, insumos e investimentos, a qual chamaram de cenário 1 , a outra, chamada de cenário 2 , baseou-se nos melhores valores praticados, valores mínimos de consumo e na melhor tecnologia existente e praticada.

Neste anexo, a partir das relações utilizadas por eles, são identificados e ajustados o consumo de energia referente a cada etapa do processo energético, a fim de atender as matrizes utilizadas no modelo.

\section{B.1 Operações agrícolas e colheita}

O consumo de óleo diesel nas operações agrícolas e colheita foi calculado por MACEDO; NOGUEIRA (1985) através da relação:

$$
E_{a c}[\mathrm{ld} / \mathrm{tC}]=\frac{[0,2 E p+0,6 \mathrm{Es}+0,8(0,15 \mathrm{Ecc}+0,85 \mathrm{Ecm})]}{\mathrm{Pa}}
$$

Onde:

$\mathrm{E}_{\mathrm{ac}}$ - consumo de óleo diesel em operações agrícolas e de colheita;

$\mathrm{Pa}$ - produtividade agrícola anual [tC/ha], $65 \mathrm{tC} / \mathrm{ha}$;

Ep - consumo de óleo diesel em operações agrícolas na cana-planta [ld/ha], $118,28 \mathrm{ld} /$ ha no cenário 1 e 45,92 ld/ha no cenário 2; 
Es - consumo de óleo diesel em operações agrícolas na cana soca [ld/ha], 13,04 ld/ha nos dois cenários;

Ecc - consumo de óleo diesel em colheita mecânica [ld/ha], 77,65 ld/ha nos dois cenários;

Ecm - consumo de óleo diesel em colheita manual, 16,25 Id/ha nos dois cenários.

Pode-se observar que a primeira parte da equação refere-se æ̀̀ operações agrícolas realizadas na fase de produção e a segunda parte à realizadas na colheita. Separando-se as duas relações obtém-se os seguintes resultados.

\section{Operações agrícolas}

A equação abaixo fornece o consumo de óleo diesel em operações agrícolas na fase de produção.

$$
E_{o a}[\mathrm{ld} / \mathrm{tC}]=\frac{0,2 \mathrm{Ep}+0,6 \mathrm{Es}}{\mathrm{Pa}}
$$

Resultados

Cenário 1: $\mathrm{E}_{\mathrm{oa}}=0,48 \mathrm{Id} / \mathrm{tC}$

Cenário 2: $\mathrm{E}_{\mathrm{oa}}=0,26 \mathrm{ld} / \mathrm{tC}$

O consumo total de energia na fase de produção de cana-de-açúcar é mostrado no capítulo 3, tabela 3.5.

\section{Colheita}

A relação utilizada por MACEDO; NOGUEIRA (1985) para calcular o consumo de óleo diesel nesta fase é desmembrada em duas: colheita mecânica e manual. Isto é feito pois o modelo cascata considera a tecnologia utilizada para colher a cana-de-açúcar.

São obtidos os seguintes resultados: 
- Para colheita mecanizada

$$
E_{m e}[\mathrm{ld} / \mathrm{tC}]=\frac{0,8 \mathrm{Ecc}}{\mathrm{Pa}}
$$

- Para colheita manual

$$
E_{m a}[\mathrm{ld} / \mathrm{tC}]=\frac{0,8 \mathrm{Ecm}}{\mathrm{Pa}}
$$

Os resultados obtidos são os mesmos para os dois cenários

Cenário 1 e 2:

$\mathrm{E}_{\mathrm{me}}=0,96 \mathrm{Id} / \mathrm{tC}$

$\mathrm{E}_{\mathrm{ma}}=0,20 \mathrm{ld} / \mathrm{tC}$

Os coeficientes de consumos de energia na fase de extração da cana-deaçúcar são mostrados no capítulo 3 , tabela 3.7.

\section{B.2 Transporte de cana-de-açúcar}

O consumo de energia no transporte de cana-de-açúcar considera apenas o insumo energético utilizado, óleo diesel.

Pode ser calculado utilizando a relação:

$$
E_{t c}\left[G J d / 10^{3} G J c\right]=\frac{e^{e d u c}{ }^{*} 2 d m^{*} 1000}{\text { aut }^{*}{ }^{*} C_{v}{ }^{*} \text { eCuc }}
$$

Onde:

ed $\mathrm{uc}_{\mathrm{uc}}$ - quantidade de energia por litro de óleo diesel [GJd//d], tabela I.4;

dm - distância média percorrida entre a lavoura e a unidade industrial [km], segundo MACEDO; NOGUEIRA (1985) para as unidades da Copersucar, 16 $\mathrm{km}$;

aut - autonomia do veículo [km/l], tabela C.4;

$\mathrm{tC}_{\mathrm{v}}$ - quantidade de cana-de-açúcar transportada por viagem [tC/viagem], tabela C.4;

ec $c_{\text {uc }}$ - quantidade de energia por tonelada de cana [GJc/tC], tabela I.4. 
Os valores obtidos constam da tabela 3.9, capítulo 3.

\section{B.3 Transporte de álcool etílico}

O transporte de álcool etílico é realizado por três modais, cada um deles consome uma quantidade diferente de combustível que varia em função da autonomia do veículo utilizado, da quantidade de produto transportada e da distância média percorrida.

Devido às particularidades de cada meio de transporte, para calcular a quantidade de energia consumida foram elaboradas equações diferentes para um deles.

\section{Transporte rodoviário}

A energia consumida por unidade de energia transportada no transporte ou distribuição de álcool utilizando caminhões é calculada através da relação:

$$
E_{\text {tar }}\left[\mathrm{GJd} / 10^{3} \mathrm{GJa}\right]=\frac{\text { educ }^{*} \mathrm{dm}^{*} 1000}{\text { aut }^{*}{ }^{*} \mathrm{a}_{\mathrm{v}}{ }^{*} \text { ea } \mathrm{uc}}
$$

Onde:

$\mathrm{ed}_{\mathrm{uc}}$ - quantidade de energia por litro de óleo diesel, tabela I.4;

dm - distância média percorrida [km], 133 km das usinas aos centros de armazenamento primário, ida e volta. Das usinas ao centro armazenador secundário, $433 \mathrm{~km}$. Estes valores são calculados no anexo E. Na distribuição de álcool aos postos de abastecimento, segundo GUERRIERO (1993), 32,5 $\mathrm{km}$;

aut - autonomia do veículo [km/l], para os caminhões que fazem o transporte das usinas aos centros armazenadores, segundo FERREIRA (1993), 1,5 km/ld. $\mathrm{Na}$ distribuição de álcool, segundo GUERRIERO (1993): $3 \mathrm{~km} / \mathrm{ld}$ para os veículos pequenos, $2,25 \mathrm{~km} / \mathrm{ld}$ para os veículos médios e $1,7 \mathrm{~km} / \mathrm{ld}$ para os veículos grandes;

$\mathrm{l}_{\mathrm{v}}$ - quantidade média de álcool transportado por viagem [la/viagem], das usinas aos centro armazenadores, segundo FERREIRA (1993), são 
transportados em média $30 \mathrm{~m}^{3}$ de álcool. Na distribuição do produto, conforme tabela C.5 do anexo $\mathrm{C}$, os caminhões pequenos transportam $4,10 \mathrm{~m}^{3}$ de álcool hidratado e $1,11 \mathrm{~m}^{3}$ de álcool anidro, os caminhões médios transportam 6,97 $\mathrm{m}^{3}$ de álcool hidratado e 1,88 $\mathrm{m}^{3}$ de álcool anidro e os grandes $11,20 \mathrm{~m}^{3}$ de álcool hidratado e 3,02 $\mathrm{m}^{3}$ de álcool anidro;

$e_{\mathrm{uc}}$ - quantidade de energia por litro de álcool, tabela I.4.

\section{Transporte ferroviário}

A quantidade de energia consumida para transportar álcool dos centros armazenadores primários ao centro armazenador secundário por ferrovia é obtida através da relação:

$$
E_{\text {taf }}\left[\mathrm{GJd} / 10^{3} \mathrm{GJa}\right]=\frac{\text { educ }^{*} \mathrm{dm}^{*} \mathrm{con}}{\text { eauc }}
$$

Onde:

$\mathrm{ed}_{\mathrm{uc}}$ - quantidade de energia por litro de óleo diesel, tabela I.4;

$\mathrm{dm}$ - distância média percorrida $[\mathrm{km}]$, entre o centro armazenador primário e o centro armazenador secundário: $310 \mathrm{~km}$ para trens com tração diesel e $274 \mathrm{~km}$ para trens com tração elétrica, valores calculados no anexo $\mathrm{E}$;

con - consumo médio de locomotivas $\left[\mathrm{uc} / \mathrm{m}^{3} / \mathrm{km}\right.$ ], segundo VOLF (1994), $0,0122 \mathrm{Id} / \mathrm{m}^{3} / \mathrm{km}$ para trens com tração diesel e $0,0929 \mathrm{kWh} / \mathrm{m}^{3} / \mathrm{km}$ para trens com tração elétrica;

ea $a_{\mathrm{uc}}$ - quantidade de energia por litro de álcool, tabela I.4.

\section{Transporte hidroviário}

Na hidrovia o coeficiente de consumo de energia é calculado pela equação:

$$
E_{\tan }\left[\mathrm{GJd} / 10^{3} \mathrm{GJa}\right]=\frac{\text { educ }^{*} \mathrm{dm}^{*}{ }^{*} \operatorname{con}^{*} 1000}{\text { vel }^{*} \mathrm{a}_{\mathrm{v}}{ }^{*} \text { eauc }}
$$

Onde: 
ed ${ }_{\mathrm{uc}}$ - quantidade de energia por litro de óleo diesel, tabela I.4;

con - consumo médio de empurradores $[\mathrm{ld} / \mathrm{h}], 80 \mathrm{ld} / \mathrm{h}$;

$\mathrm{dm}$ - distância média percorrida $[\mathrm{km}]$, entre o centro armazenador em Nova Avanhandava e o terminal de álcool na SP-191: $334 \mathrm{~km}$;

vel - velocidade média do comboio [km/h], $12 \mathrm{~km} / \mathrm{h}$;

$l a_{v}$ - quantidade média de álcool transportado por viagem [la/viagem], $1200 \mathrm{~m}^{3}$; ea $a_{\mathrm{uc}}$ - quantidade de energia por litro de álcool, tabela I.4.

Os valores acima foram fornecidos por NORONHA (1993) da divisão de estudos hidroviários da Cesp e referem-se à empurradores utilizados na hidrovia Tietê-Paraná.

\section{B.4 Transporte de bagaço de cana}

O bagaço de cana é comercializado com indústrias, da região produtora de cana-de-açúcar, para transportá-lo são utilizados dois tipos de caminhões a óleo diesel. A quantidade de óleo diesel consumida para transportar bagaço de cana das usinas até as indústrias é calculada pela relação:

$$
E_{\mathrm{tb}}\left[\mathrm{GJd} / 10^{3} \mathrm{GJa}\right]=\frac{\text { educ }^{*} \mathrm{dm}^{*} 1000}{\mathrm{aut}^{*}{ }^{*} \mathrm{tb}_{v}{ }^{*} \text { ebuc }}
$$

Onde:

ed $\mathrm{uc}_{\mathrm{uc}}$ - quantidade de energia por litro de óleo diesel, tabela I.4;

$\mathrm{dm}$ - distância média percorrida [km], $100 \mathrm{~km}$;

aut - autonomia do veículo [km/l], caminhões com 12 tb de capacidade: 3,5 km/ld. Caminhões com capacidade de 21 tb: 2 km/ld;

$t_{\mathrm{v}}$ - quantidade de bagaço de cana transportada por viagem [tb/viagem], caminhões menores transportam, em média, $12 \mathrm{t}$ de bagaço de cana por viagem. Os maiores $21 \mathrm{tb}$;

eb uc - quantidade de energia por tonelada de bagaço de cana, tabela I.4.

Valores fornecidos por LODI (1994) da divisão de vendas de outros produtos da cana-de-açúcar da Copersucar. 


\section{Anexo C - Fatores de emissão}

Os coeficientes de emissões que alimentam o modelo cascata são calculados utilizando-se dois métodos diferentes.

Os principais poluentes emitidos por veículos automotores, com exceção do dióxido de carbono, são estudados a partir do artigo "Inventário de emissão veicular - metodologia de cálculo" elaborado por MURGEL (1987). E para as emissões de dióxido de carbono provenientes de atividades consumidoras de energia é utilizado um método desenvolvido pelo Intergovernmental Panel on Climate Change (IPCC) junto com a Organization for Economic Cooperation and Development (OECD).

A seguir são mostrados os métodos e as equações utilizadas para calcular os coeficientes de emissão que compõe as matrizes de impacto utilizadas no modelo cascata.

\section{Emissões de dióxido de carbono}

Quando combustíveis que possuem carbono são queimados grande parte do carbono sofre oxidação produzindo dióxido de carbono. A quantidade de $\mathrm{CO}_{2}$ emitida pode ser estimada a partir do consumo de combustível e da quantidade de carbono que cada combustível contém, tabela C.1.

TABELA C.1 Fatores de emissão de carbono e de dióxido de carbono

\begin{tabular}{lcc}
\hline Combustíveis & $\mathrm{kg} \mathrm{C} / \mathrm{GJ}$ & $\mathrm{kg} \mathrm{CO} / \mathrm{GJ}^{(1)}$ \\
\hline Biomassa sólida & 25,8 & 93,7 \\
Biomassa líquida & 25,8 & 93,7 \\
Gasolina & 18,9 & 68,6 \\
Óleo Diesel & 20,2 & 73,3 \\
\hline
\end{tabular}

Fonte: OECD (1992c), p.2-8.

Nota: (1) Valores calculados 
Nem todo o combustível produzido é queimado, parte pode ser usado como matéria prima na fabricação de produtos, portanto não sofrem oxidação. Esta fração é chamada de "carbono isolado".

Durante a queima, outra pequena parte, aproximadamente $1 \%$, também não sofre oxidação e portanto deve ser descontada do total emitido.

Os fatores de emissão de $\mathrm{CO}_{2}$, são obtidos multiplicando o total de carbono oxidado, descontando o carbono isolado e não oxidado, pela proporção entre o peso molecular do $\mathrm{CO}_{2}$ e do carbono (44/12).

$$
\mathrm{fecO}_{2}=\left[\left(\mathrm{ce}_{(\mathrm{c})}-\text { carbono isolado }\right) * \% \text { de carbono oxidado }(99 \%)\right] * \frac{44}{12}
$$

Onde:

$\mathrm{feCO}_{2}$ - fator de emissão de dióxido de carbono

$\mathrm{ce}_{(\mathrm{c})}$ - fator de emissão de carbono

A quantidade de carbono isolado para cana-de-açúcar corresponde aos produtos não energéticos: açúcar, álcool para fins de limpeza e bagaço utilizado em indústrias de papel e celulose. Como os coeficientes de emissão no modelo cascata são aplicados apenas onde ocorre queima, não é necessário descontar este valor.

\section{C.1 Fontes móveis}

As emissões de gases e partículas em veículos automotores ocorrem através do tubo de escapamento, do sistema de alimentação de combustível, do respiro do cárter e de partículas originadas do desgaste de pneus e freios.

A emissão de gases e partículas pelo tubo de escapamento é devida às reações químicas que ocorrem no motor associadas ao processo de combustão. Os principais poluentes emitidos são CO, HC, NOx, SOx, MP, aldeídos, ácidos orgânicos e álcoois. 
A emissão de vapores através de respiros, juntas e conexões do sistema de alimentação de combustível, é denominada emissão evaporativa e basicamente depende da volatilidade do combustível e das condições ambientais.

Os gases e vapores emitidos pelo respiro do cárter são conhecidos por emissões do cárter. Esta emissão ocorre devido ao vazamento de gases de combustão e frações de combustível não queimado pelos anéis de vedação dos pistões durante os períodos de compressão e explosão do motor e se caracteriza por conter essencialmente HC. Além disso, vapores de óleo lubrificante são também constituintes das emissões do cárter.

A emissão de SOx é proporcional ao teor de enxofre do combustível; no caso da combustão de álcool a emissão é desprezível visto que o teor de enxofre neste combustível é praticamente nulo.

A emissão de material particulado, além daquela gerada no processo de combustão, também ocorre devido ao desgaste de pneus e freios. No caso dos freios, há poucas informações disponíveis, entretanto a emissão de MP desta fonte é muito inferior que a produzida pelo desgaste de pneus (MURGEL, 1987).

Devido ao volume, o que torna as demais frações pouco significantes, apenas as emissões que ocorrem pelo tubo de escapamento são consideradas neste estudo.

Para se estabelecer o inventário de emissões proposto pelo modelo cascata, os fatores de emissão são indicadores básicos; na bibliografia eles são expressos, em geral, em gramas de poluente emitido por quilômetro rodado [g/km], tabela C.2. Para se calcular a emissão, em massa, do poluente, utilizando o modelo proposto neste trabalho, é necessário que o fator de emissão seja expresso em toneladas de poluente emitido por quantidade de energia, neste caso milhares de gigajoules $\left[\mathrm{t} / 10^{3} \mathrm{GJ}\right]$. 
TABELA C.2 Fatores de emissão da frota de veículos da Região Metropolitana de São Paulo em 1985

\begin{tabular}{lcccccc}
\hline \multicolumn{1}{c}{ Tipo de } & \multicolumn{6}{c}{ Gases de escapamento [g/km] } \\
combustível & CO & HC & NOx & SOx & MP & HCHO $^{(2)}$ \\
\hline Álcool $^{1}$ & 18,8 & 1,56 & 1,09 & - & - & 0,160 \\
Gasool $^{(1)}$ & 40,5 & 3,77 & 1,40 & 0,16 & 0,21 & 0,040 \\
Diesel & 17,8 & 2,90 & 13,0 & 5,95 & 0,81 & - \\
\hline
\end{tabular}

Fonte: MURGEL (1987).

Notas: $(1)$ gasool $=78 \%$ gasolina $+22 \%$ álcool

(2) SÃO PAULO (1992b), p.16.

\section{C.1.1 Operações agrícolas e colheita}

Grande parte das operações agrícolas são realizadas por tratores. Estes, devido à sua construção, possuem fatores de emissão diferentes de veículos leves e caminhões. Os fatores de emissão utilizados no cálculo dos coeficientes de impacto são fornecidos pela Environmental Protection Agency e mostrados na tabela C.3.

TABELA C.3 Fatores de emissão para tratores a óleo diesel

\begin{tabular}{lc}
\hline Poluente & {$\left[\mathrm{kg} / 10^{3} \mathrm{l}\right]$} \\
\hline Aldeídos & 1,45 \\
Hidrocarbonetos & 7,28 \\
Monóxido de carbono & 14,3 \\
Óxidos de enxofre ${ }^{(1)}$ & 3,74 \\
Óxidos de nitrogênio & 40,2 \\
Particulados & 5,48 \\
\hline
\end{tabular}

Fonte: UNITED STATES OF AMERICA (1985b), vol.2, table II-6.2.

Nota: (1) Não medido. Calculado a partir de combustível contendo 0,22\% de enxofre. 
A equação utilizada para calcular as emissões provenientes de equipamentos utilizados em operações agrícolas e colheita é:

$$
F e_{o a}\left[t / 10^{3} G J\right]=\frac{f e^{*} \operatorname{con}}{\text { ecuc }^{*} 10^{6}}
$$

Onde:

fe - fator de emissão $\left[\mathrm{kg} / 10^{3} \mathrm{l}\right]$, tabela C.3;

con - consumo de óleo diesel por tonelada de cana $[\mathrm{ld} / \mathrm{tC}]$, no anexo $B$ são calculados o consumo de óleo diesel para cada fase. Em operações agrícolas é consumido $0,48 \mathrm{ld} / \mathrm{tC}$ no cenário 1 e 0,26 ld/tC no cenário 2 . Na colheita o consumo é o mesmo para os dois cenários, mas $0,96 \mathrm{Id} / \mathrm{tC}$ é consumido em colheita mecanizada e 0,20 ld/tC em colheita manual;

$\mathrm{ec}_{\text {uc }}$ - quantidade de energia por tonelada de cana, tabela I.4.

$\mathrm{O}$ coeficiente de emissão de $\mathrm{CO}_{2}$ é calculado utilizando a equação:

$$
\mathrm{FeCO}_{2 \circ}\left[\mathrm{t} / 10^{3} \mathrm{GJC}\right]=\frac{\mathrm{fecO}_{2}{ }^{*} \mathrm{con}^{*} \text { educ }}{\mathrm{ec}}
$$

Onde:

$\mathrm{feCO}_{2}$ - fator de emissão de dióxido de carbono [kg/GJ], tabela C.1;

ed $\mathrm{uc}_{\mathrm{uc}}$ - quantidade de energia por litro de óleo diesel, tabela I.4.

Os valores obtidos são mostrados no capítulo 3, na tabela 3.3, os referentes as operações agrícolas e na tabela 3.6, os referentes a colheita.

\section{C.1.2 Transporte de cana-de-açúcar}

No transporte de cana-de-açúcar da lavoura até a usina são utilizados cinco tipos de caminhões. Suas características, mostradas na tabela C.4 e utilizadas no cálculo dos fatores de emissão, foram fornecidas por KOLLER (1993). 
TABELA C.4 Capacidade e autonomia de caminhões utilizados em transporte de cana-de-açúcar

\begin{tabular}{lcc}
\hline Tipo de veículo & $\begin{array}{c}\text { Capacidade } \\
{[\mathrm{tC}]}\end{array}$ & $\begin{array}{c}\text { Autonomia } \\
{[\mathrm{km} /]}\end{array}$ \\
\hline toco & 10 & 3,6 \\
truck & 15 & 2,2 \\
romeu e julieta & 28 & 1,7 \\
treminhão & 45 & 1,2 \\
rodotrem & 50 & 1,0 \\
\hline
\end{tabular}

Fonte: KOLLER (1993).

Os coeficientes de emissão para veículos utilizados em transporte de cana, mostrados no capítulo 3, tabela 3.8, são calculados pela relação:

$$
F_{\text {tc }}\left[t / 10^{3} G J c\right]=\frac{f e^{*} 2 d m}{t^{*}{ }^{*} e_{u c}{ }^{*} 10^{6}}
$$

Onde:

fe - fator de emissão [g/km], tabela C.2;

dm - distância média percorrida [km], entre a lavoura e as unidades industriais, segundo MACEDO; NOGUEIRA (1985), 16 km;

$\mathrm{tC}_{\mathrm{v}}$ - quantidade média de cana-de-açúcar transportada por viagem [tC/viagem], tabela C.4;

$\mathrm{ec}_{\mathrm{uc}}$ - quantidade de energia por tonelada de cana, tabela I.4.

No cálculo da emissão de $\mathrm{CO}_{2}$, o coeficiente é obtido utilizando a equação:

$$
\mathrm{FecO}_{2 \mathrm{tc}}\left[\mathrm{t} / 10^{3} \mathrm{GJc}\right]=\frac{\mathrm{fecO}_{2}{ }^{*} 2 \mathrm{dm}^{*} \text { educ }}{\mathrm{tC}_{\mathrm{v}}{ }^{*} \mathrm{eC}_{\mathrm{uc}}{ }^{*} \text { aut }}
$$

Onde:

$\mathrm{feCO}_{2}$ - fator de emissão de dióxido de carbono $\left[\mathrm{kg} \mathrm{CO}_{2} / \mathrm{GJ}\right]$, tabela C.1;

$e_{\mathrm{uc}}$ - quantidade de energia por litro de óleo diesel, tabela I.4;

aut - autonomia do veículo [km/l], tabela C.4; 


\section{C.1.3 Transporte de álcool etílico}

O transporte de álcool, como visto no capítulo 3, é realizado por três modais: rodovia, ferrovia e hidrovia, cada um com seu custo, eficiência e impacto ambiental.

Neste item são calculados os coeficientes de emissão de cada modal, e para isto são utilizadas as relações mostradas àseguir.

\section{Transporte rodoviário}

A relação que calcula os coeficientes de emissão para o transporte de álcool através de caminhões a óleo diesel depende, basicamente, do volume de álcool transportado e da distância média percorrida.

A relação que fornece os valores das tabelas 3.14 , 3.17 e 3.18 do capítulo 3 é:

$$
\mathrm{Fe}_{\mathrm{tar}}\left[\mathrm{t} / 10^{3} \mathrm{GJa}\right]=\frac{\mathrm{fe}^{*} \mathrm{dm}}{\mathrm{la}_{v}{ }^{*} \text { eauc }^{*} 10^{6}}
$$

Onde:

fe - fator de emissão $[\mathrm{g} / \mathrm{km}]$, tabela C.2;

dm - distância média percorrida [km], entre usinas e centros armazenadores primários, $133 \mathrm{~km}$, ida e volta. Entre usinas e Paulínia, $433 \mathrm{~km}$, valores médios calculados no anexo E. Na distribuição, segundo GUERRIERO (1993), 32,5 $\mathrm{km}$;

$\mathrm{la}_{v}$ - quantidade média de álcool transportada por viagem [la/viagem], 30.000 la/viagem, segundo FERREIRA (1993), para os veículos que fazem o transporte das usinas aos centros de armazenamento. A tabela C.5 mostra os valores para os caminhões que fazem a distribuição;

$\mathrm{ea}_{\mathrm{uc}}$ - quantidade de energia por litro de álcool, tabela I.4.

O coeficiente de emissão de dióxido de carbono é calculado utilizando a relação: 


$$
\text { Feco } 2 \operatorname{tar}\left[\mathrm{t} / 10^{3} \mathrm{GJa}\right]=\frac{\mathrm{fecO}_{2}{ }^{*} \mathrm{dm}^{*} \text { educ }}{\operatorname{lav}^{*}{ }^{*} \text { eauc }{ }^{*} \text { aut }}
$$

Onde:

$\mathrm{feCO}_{2}$ - fator de emissão de dióxido de carbono $\left[\mathrm{kg} \mathrm{CO}_{2} / \mathrm{GJ}\right]$, tabela C.1; $\mathrm{ed}_{\mathrm{uc}}$ - quantidade de energia por litro de óleo diesel, tabela I.4; aut - autonomia do veículo [km/l], segundo FERREIRA (1993), 1,5 km/l para os caminhões que fazem o transporte de álcool das usinas aos centros armazenadores. Para os que fazem a distribuição, segundo GUERRIERO (1993): pequenos: 3,0 km/l, médios: 2,25 km/l e grandes: $1,7 \mathrm{~km} / \mathrm{l}$.

O volume transportado por caminhões que fazem a distribuição de álcool, tabela C.5, é calculado utilizando as informações da tabela E.5 no anexo E, fornecidas por GUERRIERO (1993) para a Shell do Brasil.

TABELA C.5 Volume de álcool etílico transportado na distribuição

\begin{tabular}{lcc}
\hline $\begin{array}{l}\text { Tamanho dos } \\
\text { caminhões }\end{array}$ & $\begin{array}{c}\text { Volume de álcool hidrat. } \\
\text { transportado }\left[\mathrm{m}^{3}\right]\end{array}$ & $\begin{array}{c}\text { Volume de álcool anidro } \\
\text { transportado }\left[\mathrm{m}^{3}\right]\end{array}$ \\
\hline pequenos & 4,103 & 1,108 \\
médios & 6,974 & 1,883 \\
grandes & 11,200 & 3,024 \\
\hline
\end{tabular}

\section{Transporte ferroviário}

Os fatores de emissão, encontrados na bibliografia para locomotivas e que são utilizados nos cálculos dos coeficientes de emissão, estão listados na tabela C.6.

A partir das informações de VOLF (1994), os coeficientes de emissão para locomotivas, tabela 3.15 do capítulo 3 , são calculados utilizando a relação:

$$
F e_{\text {tat }}\left[\mathrm{t} / 10^{3} \mathrm{GJa}\right]=\frac{\mathrm{fe}^{*} \mathrm{dm}^{*} \mathrm{con}}{\text { eauc }^{*} 10^{9}}
$$


Onde:

fe - fator de emissão $\left[\mathrm{kg} / 10^{3} \mathrm{l}\right]$, tabela C.6;

con - consumo médio [ld// $\mathrm{m}^{3} / \mathrm{km}$ ], segundo VOLF (1994), para locomotivas com tração diesel: 0,0122 ld/ $/ \mathrm{m}^{3} / \mathrm{km}$;

$\mathrm{dm}$ - distância média percorrida [km], entre centros armazenadores primários e Paulínia, $310 \mathrm{~km}$, valor calculado no anexo E;

$\mathrm{ea}_{\mathrm{uc}}$ - quantidade de energia por litro de álcool, tabela I.4.

Para o coeficiente de emissão de $\mathrm{CO}_{2}$ :

$$
\mathrm{FecO}_{2 \mathrm{tat}}\left[\mathrm{t} / 10^{3} \mathrm{GJa}\right]=\frac{\mathrm{fecO}_{2}{ }^{*} \mathrm{dm}^{*}{ }^{*} \text { educ }{ }^{*} \operatorname{con}}{\text { eauc }^{*} 1000}
$$

Onde:

$\mathrm{feCO}_{2}$ - fator de emissão de dióxido de carbono $\left[\mathrm{kg} \mathrm{CO}_{2} / \mathrm{GJ}\right]$, tabela C.1;

$e_{\mathrm{uc}}$ - quantidade de energia por litro de óleo diesel, tabela I.4.

TABELA C.6 Fatores de emissão para locomotivas

\begin{tabular}{lc}
\hline Poluente & {$\left[\mathrm{kg} / 10^{3} \mathrm{l}\right]$} \\
\hline Ácidos orgânicos & 0,84 \\
Aldeídos & 0,66 \\
Hidrocarbonetos & 11 \\
Monóxido de carbono & 16 \\
Óxidos de enxofre $^{(1)}$ & 6,8 \\
Óxidos de nitrogênio & 44 \\
Particulados & 3,0 \\
\hline
\end{tabular}

Fonte: UNITED STATES OF AMERICA (1985b), vol.2, table II-2.1

Nota: (1) Baseado em combustível contendo $0,4 \%$ de enxofre, em peso.

\section{Transporte hidroviário}

Para calcular os coeficientes de emissão dos empurradores utilizados em transporte hidroviário, tabela 3.16 do capítulo 3 , parte-se dos fatores de emissão fornecidos pela EPA, tabela C.7, e utiliza-se a relação: 


$$
F e_{\text {tan }}\left[t / 10^{3} \mathrm{GJa}\right]=\frac{\mathrm{fe}^{*} \mathrm{dm}^{*} \text { con }}{\text { vel }^{*} \mathrm{al}_{\mathrm{v}}{ }^{*} \text { eauc }^{*} 10^{6}}
$$

Onde:

fe - fator de emissão $\left[\mathrm{kg} / 10^{3} \mathrm{l}\right]$, tabela C.7;

con - consumo médio de empurradores [ld/h], $80 \mathrm{ld} / \mathrm{h}$;

dm - distância média percorrida $[\mathrm{km}]$, entre o centro armazenador primário em Nova Avanhandava e Santa Maria da Serra: 334 km;

vel - velocidade média do comboio [km/h], $12 \mathrm{~km} / \mathrm{h}$;

$l a_{v}$ - quantidade de álcool transportada por viagem [la/viagem], $1.200 \mathrm{~m}^{3}$;

ea $a_{\mathrm{uc}}$ - quantidade de energia por litro de álcool, tabela I.4.

Valores fornecidos por NORONHA (1993) da divisão de estudos hidroviários da Cesp, referentes a empurradores utilizados na hidrovia Tietê-Paraná.

$\mathrm{O}$ coeficiente de emissão de $\mathrm{CO}_{2}$ é calculado através da equação:

$$
\text { Feco } 2 \tan \left[t / 10^{3} \mathrm{GJa}\right]=\frac{\mathrm{fecO}_{2}{ }^{*} \mathrm{dm}^{*} \text { educ }^{*} \mathrm{con}}{\mathrm{vel}^{*} \text { eauc }^{*} \mathrm{a}_{\mathrm{v}}}
$$

Onde:

$\mathrm{feCO}_{2}$ - fator de emissão de dióxido de carbono [ $\mathrm{kg} \mathrm{CO} / \mathrm{GJ}$ ], tabela C.1;

$e_{\mathrm{uc}}$ - quantidade de energia por litro de óleo diesel, tabela I.4.

TABELA C.7 Fatores de emissão médios para barcos comerciais em rios

\begin{tabular}{lc}
\hline Poluente & {$\left[\mathrm{kg} / 10^{3} \mathrm{l}\right]$} \\
\hline Hidrocarbonetos & 6,0 \\
Monóxido de carbono & 12 \\
Óxidos de enxofre ${ }^{(1)}$ & 3,2 \\
Óxidos de nitrogênio & 33 \\
Particulados & 5,9 \\
\hline
\end{tabular}

Fonte: UNITED STATES OF AMERICA (1985b), vol.2, table II-3.1

Notas: (1) Calculado, não medido. Baseado em combustível contendo 0,20\% de enxofre, em peso e densidade de $0,854 \mathrm{~kg} / \mathrm{l}$. 


\section{C.1.4 Transporte de bagaço de cana}

A relação que calcula os coeficientes de emissão da tabela 3.19 do capítulo 3 é:

$$
F_{e t b}\left[t / 10^{3} G J b\right]=\frac{f e * d m}{t_{b v}^{*}{ }^{*} b_{u c}{ }^{*} 10^{6}}
$$

Onde:

fe - fator de emissão [ $\mathrm{g} / \mathrm{km}]$, tabela C.2;

dm - distância média percorrida [km], entre produtor, usinas e destilarias, e consumidor são percorridos, em média, segundo LODI (1994), 100 km, ida e volta;

$t_{v}$ - quantidade média de bagaço de cana transportada por viagem [tb/viagem], segundo LODI (1994), em média, os caminhões menores transportam 12 tb e os maiores $21 \mathrm{tb}$;

eb $b_{u c}$ - quantidade de energia por tonelada de bagaço de cana, tabela I.4.

Para o coeficiente de emissão de $\mathrm{CO}_{2}$ :

$$
\mathrm{FecO}_{2 \mathrm{tb}}\left[\mathrm{t} / 10^{3} \mathrm{GJb}\right]=\frac{\mathrm{fecO}_{2}{ }^{*} \mathrm{dm}^{*} \text { educ }}{\mathrm{aut}^{*}{ }^{*} \mathrm{ebuc}^{*}{ }^{*} \mathrm{tb}_{\mathrm{v}}}
$$

Onde:

$\mathrm{feCO}_{2}$ - fator de emissão de dióxido de carbono [ $\left.\mathrm{kg} \mathrm{CO}_{2} / \mathrm{GJ}\right]$, tabela C.1;

$\mathrm{ed}_{\mathrm{uc}}$ - quantidade de energia por litro de óleo diesel, tabela I.4;

aut - autonomia do veículo [km/l], segundo LODI (1994), caminhões com capacidade de 12 t: 3,5 km/ld; e caminhões com capacidade de 21 t: 2,0 km/l.

\section{C.1.5 Uso final}

Após o processo de transformação, o álcool é distribuído e está disponível em bombas de combustível para ser consumido.

Os motores ciclo Otto a álcool possuem, segundo MURGEL (1987), os fatores de emissão mostrados na tabela C.2. 
A equação que calcula os coeficientes de emissão dos veículos automotores a álcool mostrados na tabela 3.24 do capítulo 3, é:

$$
\text { Feur }\left[t / 10^{3} \mathrm{GJa}\right]=\frac{\text { fe }{ }^{*} \text { aut }}{\text { eauc }{ }^{*} 10^{6}}
$$

Onde:

fe - fator de emissão $[\mathrm{g} / \mathrm{km}]$, tabela C.2;

aut - autonomia média dos veículos a álcool com motores ciclo Otto [km/l], 6,6 km/l (SÃO PAULO, 1991a);

ea $a_{\mathrm{uc}}$ - quantidade de energia por litro de álcool, tabela I.4.

$\mathrm{O}$ coeficiente de emissão de $\mathrm{CO}_{2}$ é obtido diretamente utilizando o fator de emissão para biomassa líquida da tabela C.1.

\section{C.2 Fontes estacionárias}

As maiores fontes de emissão estacionárias no processamento de cana-deaçúcar são as queimadas antes da colheita e a incineração de bagaço de cana como combustível em caldeiras. Em outros processos: moagem, secagem e cristalização, pequenas quantidades de particulados são emitidos.

A absorção de $\mathrm{CO}_{2}$ na fase de crescimento da cana-de-açúcar é outra fonte estacionária a ser estudada.

\section{C.2.1 Absorção de $\mathrm{CO}_{2}$ no crescimento da cana-de-açúcar}

A análise do ciclo do carbono deve considerar os períodos relativos aos ciclos envolvidos. No Brasil, a cana é uma cultura anual, com média de quatro cortes antes do novo plantio. Para as partes aéreas (colmo, folhas e pontas) o ciclo é basicamente anual. As folhas são queimadas durante a colheita e uma pequena parte fica no solo decompõe-se lentamente. $\mathrm{O}$ bagaço, resultado da moagem da cana, é queimado para uso energético. E a sacarose é 
transformada em açúcar, para consumo, ou álcool, os quais são consumidos dentro de um ano.

As partes subterrâneas, raízes, têm um ciclo mais longo: o conjunto cresce, fixa carbono e permanece no solo por quatro anos com certa renovação anual, no final é erradicado parcialmente, parte continua no subsolo e a parte erradicada é incorporada, na superfície. Portanto, parte da matéria orgânica é incorporada ao solo, correspondendo a uma fixação líquida de carbono atmosférico, ao longo dos anos (MACEDO, 1991).

A contribuição líquida para o teor de $\mathrm{CO}_{2}$ atmosférico, resultante da incorporação de matéria orgânica ao solo, na cultura da cana, deve vir das diferenças no teor final de carbono no solo antes do cultivo da cana e um certo número de anos após o início. Essas diferenças variam muito em função do tipo de solo (arenoso, argiloso), do cultivo e da cultura anteriormente existente (mata, cerrado, pasto).

O coeficiente de absorção de $\mathrm{CO}_{2}$ mostrado na tabela 3.3 é calculado através da relação abaixo e permite uma quantificação estimada da quantidade bruta absorvida pela cana de açúcar durante a fase de crescimento.

$$
\text { Feco } 2 a b\left[t / 10^{3} \mathrm{GJC}\right]=\frac{\mathrm{facO}_{2}}{\mathrm{~Pa}^{*} \mathrm{CC}_{\mathrm{uc}}}
$$

Onde:

$\mathrm{facO}_{2}$ - fator de absorção de dióxido de carbono na fase de crescimento da cana-de-açúcar [t CO $\mathrm{CO}_{2} / \mathrm{ha}$ ], segundo SANTAELLA (1994), 129 t CO$/$ /ha/ano;

$\mathrm{Pa}$ - produtividade agrícola anual [tC/ha], 81,77 tC/ha, tabela A.1;

$\mathrm{ec}_{\mathrm{uc}}$ - quantidade de energia por tonelada de cana-de-açúcar, tabela I.4.

\section{C.2.2 Queima de cana-de-açúcar no campo}

O canavial é queimado a fim de remover folhas e palhas, propiciar um melhor rendimento no corte e reduzir a presença de impurezas vegetais na cana enviada para moagem.

Os fatores de emissão para a queima de canavial são fornecidos pela EPA e mostrados na tabela C.8. 
Os coeficientes de emissão para a queima de cana-de-açúcar no campo são calculados a partir da relação:

$$
F e_{q c}\left[t / 10^{3} G J\right]=\frac{f e}{\text { ecuc }^{*} 1000}
$$

Onde:

fe - fator de emissão $[\mathrm{kg} / \mathrm{tC}]$, tabela C.8, são utilizados os valores mais altos considerando a pior condição possível;

ec $c_{u c}$ - quantidade de energia por tonelada de cana-de-açúcar, tabela I.4.

$\mathrm{O}$ coeficiente de emissão de $\mathrm{CO}_{2}$ é calculado através da relação:

$$
\text { Feco } 2{ }_{a c}\left[t / 10^{3} \mathrm{GJc}\right]=\frac{\mathrm{fecO}_{2}}{\mathrm{~Pa}^{*} \mathrm{eC}_{\mathrm{uc}}}
$$

Onde:

$\mathrm{feCO}_{2}$ - fator de emissão de dióxido de carbono $\left[\mathrm{tCO}_{2} / \mathrm{ha}\right]$, segundo SANTAELLA (1994), 2,1 $\mathrm{tCO}_{2} / \mathrm{ha} /$ ano;

$\mathrm{Pa}$ - produtividade agrícola anual [tC/ha], 81,77 tC/ha, tabela A.1;

$\mathrm{ec}_{\mathrm{uc}}$ - quantidade de energia por tonelada de cana-de-açúcar, tabela I.4.

TABELA C.8 Fatores de emissão para queima de cana-de-açúcar no campo

\begin{tabular}{lc}
\hline Poluentes & {$[\mathrm{kg} / \mathrm{tC}]^{(1)}$} \\
\hline Hidrocarbonetos & $2,6-8$ \\
Monóxido de carbono & $30-41$ \\
Particulados & $2,5-3,5$ \\
\hline
\end{tabular}

Fonte: UNITED STATES OF AMERICA (1985a), vol.1, table 2.4-2

Nota: (1) Valores expressos em peso de poluente emitido/peso de material queimado.

\section{C.2.3 Usinas e destilarias}

O bagaço é a fibra residual do processamento de cana-de-açúcar em usinas e destilarias. $O$ bagaço é queimado em caldeiras a fim de produzir vapor e 
eletricidade necessários aos processos e eliminar o problema de disposição deste resíduo. O bagaço representa aproximadamente $30 \%$ em peso da canade-açúcar e o maior poluente são os particulados. A emissão de particulados pode ser reduzida com a utilização de equipamentos de controle, os quais não são considerados neste estudo.

Os fatores de emissão para caldeiras a bagaço de cana estão relacionados na tabela C.9.

A tabela 3.25 é obtida a partir dos valores da tabela C.9 convertidos pela relação abaixo.

$$
F e_{a b}\left[t / 10^{3} G J b\right]=\frac{f e}{e b u c{ }^{*} 1000}
$$

Onde:

fe - fator de emissão [kg/tb], tabela C.9;

eb $b_{\text {uc }}$ quantidade de energia por tonelada de bagaço de cana, tabela I.4.

TABELA C.9 Fatores de emissão para caldeiras a bagaço de cana sem controle

\begin{tabular}{lc}
\hline Poluente & {$[\mathrm{kg} / \mathrm{tb}]^{(1)}$} \\
\hline Óxidos de enxofre & $(2)$ \\
Óxidos de nitrogênio & 0,6 \\
Particulados & 8 \\
\hline
\end{tabular}

Fonte: UNITED STATES OF AMERICA (1985a), vol.1, table 1.8-1

Notas:(1) Emissões calculadas considerando o bagaço com $50 \%$ de umidade. (2) Emissão de óxidos de enxofre a partir da queima de bagaço pode ser considerada desprezível, pois normalmente o bagaço contém menos de $0,1 \%$ de enxofre em peso. 


\section{Anexo D - Custos relativos à cana-de-açúcar e seus produtos}

Segundo a COPERSUCAR (1989b), diversos estudos têm sido realizados a fim de determinar os custos inerentes à produção da cana-de-açúcar e seus derivados ${ }^{1}$. Os resultados obtidos concentram-se numa faixa relativamente estreita, e a disparidade entre eles é explicada pela utilização de métodos distintos. As diferenças ocorrem devido a alguns aspectos dentre os quais vale ressaltar:

- amostragem: alguns trabalhos baseiam-se em amostragem de unidades produtoras, enquanto outros fundamentam-se em dados de projetos ou ainda, em coeficientes técnicos padronizados;

- conceitos de custos utilizados: algumas análises tomam como referência os custos privados de produção, enquanto outras consideram os custos sociais;

- conceitos de custos de capital: enquanto algumas instituições consideram a remuneração global do capital investido, outras adotam remunerações diferenciadas para o capital próprio e de terceiros;

- diferença no número de cortes adotados para a cana-de-açúcar e no rendimento agrícola;

- diferentes critérios de determinação do custo da terra;

- diferentes distâncias médias no transporte de matéria prima;

- diferença no rendimento industrial;

- discrepância quanto ao volume dos investimentos necessários, vida útil dos equipamentos e critérios de depreciação;

- métodos alternativos de determinação dos custos do capital de giro.

\footnotetext{
1 Ver "Subsídios para fixação dos preços da cana-de-açúcar, do açúcar e do álcool safra 1985 - 1986" (BRASIL, s/d) e "Custos de produção de cana, açúcar e álcool, safra 1978-79" (COPERSUCAR, 1978).
} 
Certamente devido aos aspectos citados acima o valor obtido neste trabalho será diferente dos demais.

Os custos são calculados por fase do processo energético buscando detalhar a análise e as conclusões.

Foram considerados apenas os valores dos insumos energéticos e agrícolas. Os custos de mão-de-obra, manutenção e depreciação de equipamentos e instalações, despesas administrativas, custos financeiros, impostos e taxas não são computados devido a falta de informações que permitam considerá-los em todo o processo.

\section{D.1 Transporte de cana-de-açúcar}

No transporte de cana-de-açúcar dois fatores são considerados nos custos: 0 tipo de veículo utilizado e a quantidade de energia consumida. Os resultados estão mostrados no capítulo 3 , tabela 3.9 e foram obtidos àpartir da relação:

$$
\mathrm{C}_{\mathrm{tc}}\left[\mathrm{US} \$ / 10^{3} \mathrm{GJC}\right]=\frac{\mathrm{pd}^{*} 2 \mathrm{dm}}{\text { aut }^{*} \mathrm{tC}_{\mathrm{v}}{ }^{*} \text { eCuc }}
$$

Onde:

pd - preço do óleo diesel [US\$/I], tabela I.3;

dm - distância média percorrida entre a lavoura e a unidade industrial [km], segundo MACEDO; NOGUEIRA (1985), para as unidades da Copersucar, 16 $\mathrm{km}$;

aut - autonomia do veículo [km/l], tabela C.4;

$\mathrm{tC}_{\mathrm{v}}$ - quantidade de cana-de-açúcar transportada por viagem [tC/viagem], tabela C.4;

$\mathrm{ec}_{\mathrm{uc}}$ - quantidade de energia por tonelada de cana, tabela I.4.

\section{D.2 Transporte de álcool etílico}

No transporte de álcool etílico apenas o custo do insumo energético utilizado, óleo diesel, é considerado. Os resultados variam em função do modal utilizado e são calculados através das relações: 


\section{Transporte rodoviário}

$$
C_{\text {tar }}\left[U S \$ / 10^{3} \mathrm{GJa}\right]=\frac{\mathrm{pd}^{*} \mathrm{dm}}{\mathrm{aut}^{*} \mid \mathrm{a}_{v}{ }^{*} \text { ea }}
$$

Onde:

pd - preço do óleo diesel [US $\$ / I$, tabela I.3;

dm - distância média percorrida [km], calculada no anexo E. De usinas ao centro armazenador primário $133 \mathrm{~km}$, ida e volta. De usinas ao centro armazenador secundário $433 \mathrm{~km}$ e na distribuição do produto, segundo GUERRIERO (1993), 32,5 km;

aut - autonomia do veículo [km/l], segundo FERREIRA (1993), os caminhões utilizados em transporte de álcool de usinas a centros armazenadores têm uma autonomia de 1,5 km/l. Para os veículos utilizados em distribuição ver capítulo 3, tabela 3.18;

$\mathrm{la}_{\mathrm{v}}$ - quantidade média de álcool transportada por viagem [la/viagem], os caminhões utilizados em transporte de álcool das unidades industriais aos centros armazenadores transportam, em média, segundo FERREIRA (1993), $30 \mathrm{~m}^{3}$ do produto. Os caminhões utilizados em distribuição de combustíveis possuem capacidades diferentes que estão mostradas no anexo C, tabela C.5. $\mathrm{ea}_{\mathrm{uc}}$ - quantidade de energia por litro de álcool, tabela I.4.

\section{Transporte ferroviário}

$$
C_{\text {taf }}\left[\text { US } \$ / 10^{3} \mathrm{GJa}\right]=\frac{\mathrm{pe}^{*} \operatorname{con}^{*} \mathrm{dm}}{\text { eauc }{ }^{*} 1000}
$$

Onde:

pe - preço do energético utilizado [US $\$ /$ uc], tabela I.3. A tarifa de energia elétrica cobrada da ferrovia é a A2 azul (VOLF, 1994); 
con - consumo médio. Locomotivas tracionadas a óleo diesel consomem em média $0,0122 \mathrm{ld} / \mathrm{m}^{3} / \mathrm{km}$ e locomotivas com tração elétrica $0,0929 \mathrm{kWh} / \mathrm{m}^{3} / \mathrm{km}$ (VOLF, 1994);

dm - distância média percorrida. Calculada no anexo E. No trecho com tração a óleo diesel $310 \mathrm{~km}$ e no trecho com tração elétrica 274 km;

ea $\mathrm{uc}_{\mathrm{uc}}$ quantidade de energia por litro de álcool, tabela I.4.

\section{Transporte hidroviário}

$$
C_{\text {tah }}\left[U S \$ / 10^{3} \mathrm{GJa}\right]=\frac{\mathrm{pd}^{*} \operatorname{con}^{*} \mathrm{dm}}{\mathrm{vel}^{*} \mid \mathrm{a}_{\mathrm{v}}{ }^{*} \text { eauc }}
$$

Onde:

pd - preço do óleo diesel [US\$/I], tabela I.3;

con - consumo médio $[\mathrm{ld} / \mathrm{h}], 80 \mathrm{ld} / \mathrm{h}$;

dm - distância média percorrida $[\mathrm{km}]$, no transporte de álcool de Nova Avanhandava a Santa Maria da Serra, $334 \mathrm{~km}$;

vel - velocidade média $[\mathrm{km} / \mathrm{h}], 12 \mathrm{~km} / \mathrm{h}$;

$l a_{v}$ - quantidade de álcool transportada por viagem [la/viagem], $1200 \mathrm{~m}^{3}$;

ea $\mathrm{u}_{\mathrm{uc}}$ - quantidade de energia por litro de álcool, tabela I.4.

Os dados acima foram fornecidos por NORONHA (1993) da divisão de estudos hidroviários da Cesp e são referentes as barcas utilizadas na hidrovia TietêParaná.

\section{D.3 Transporte de bagaço de cana}

No transporte de bagaço de cana são utilizados dois tipos caminhões movidos a óleo diesel. $O$ custo refere-se ao insumo energético utilizado e é obtido utilizando a relação:

$$
\mathrm{C}_{\mathrm{tb}}\left[\mathrm{US} \$ / 10^{3} \mathrm{GJb}\right]=\frac{\mathrm{pd}^{*} \mathrm{dm}}{\mathrm{aut}^{*} \mathrm{tb}_{\mathrm{v}}{ }^{*} \text { ebuc }}
$$


Onde:

pd - preço do óleo diesel [US\$/I], tabela I.3;

dm - distância média percorrida [km], 100 km;

aut - autonomia do veículo [km/l], para caminhões com 12 t de capacidade: 3,5 $\mathrm{km} / \mathrm{l}$. Para caminhões com $21 \mathrm{t}$ de capacidade: $2 \mathrm{~km} /$;

$\mathrm{tb}_{\mathrm{v}}$ - quantidade de bagaço de cana transportada por viagem [tb/viagem], pode ser 12 t ou 21 t, varia em função do tipo de caminhão utilizado;

eb $b_{u c}$ - quantidade de energia por tonelada de bagaço, tabela I.4.

Os valores foram fornecidos por LODI (1994) da divisão de vendas de outros produtos da cana-de-açúcar da Copersucar. 


\section{Anexo E - Transporte e distribuição de álcool etílico}

Todo álcool produzido para chegar ao consumidor final precisa ser transportado; trata-se de um caminho longo que possui várias etapas e são utilizados vários modais.

Após ser analisado por técnicos da Petrobrás e liberado para o consumo, cerca de $20 \%$ do álcool etílico, tabela E.1, é distribuído na região produtora. Os restantes $80 \%$ seguem das usinas aos centros armazenadores.

TABELA E.1 Produção e consumo de álcool em milhares de $\mathrm{m}^{3}$, segundo regiões administrativas do Estado de São Paulo, em 1988.

\begin{tabular}{|c|c|c|c|c|c|}
\hline \multirow{2}{*}{$\begin{array}{c}\text { Regiões } \\
\text { Administrativas }\end{array}$} & \multicolumn{2}{|c|}{ Álcool hidratado } & \multicolumn{2}{|c|}{ Álcool Anidro } & \multirow{2}{*}{$\begin{array}{l}\text { Gasolina } \\
\text { Consumo }\end{array}$} \\
\hline & Consumo & Produção & Consumo & Produção & \\
\hline Metropolitana & 2.098 & & 433 & & 1968 \\
\hline Registro & 20 & & 4 & & 16 \\
\hline Santos & 132 & & 23 & & 106 \\
\hline S.J. dos Campos & 161 & & 37 & & 169 \\
\hline Pres. Prudente & 62 & & 12 & & 54 \\
\hline Sorocaba & 171 & 176,2 & 39 & 43,1 & 176 \\
\hline Campinas & 467 & $1.158,1$ & 105 & 173,2 & 478 \\
\hline Ribeirão Preto & 242 & $2.533,9$ & 51 & 749,8 & 233 \\
\hline Bauru & 79 & 871,5 & 16 & 144,8 & 73 \\
\hline S.J. do Rio Preto & 104 & 593,4 & 22 & 22,5 & 98 \\
\hline Araçatuba & 47 & 626,1 & 10 & 74,3 & 44 \\
\hline Marília & 72 & 441,5 & 14 & 117,8 & 62 \\
\hline Total & 3.655 & $6.400,7$ & 765 & $1.325,5$ & 3.477 \\
\hline $\begin{array}{l}\text { Consumo em } \\
\text { regiões } \\
\text { produtoras }\end{array}$ & 1.182 & $18,47 \%$ & 256 & $19,32 \%$ & 1.164 \\
\hline
\end{tabular}

Fonte: SÃO PAULO (1991 b).

Do total do álcool etílico produzido no Estado de São Paulo, $41 \%$ segue, por rodovia, das usinas aos centros armazenadores, $29,6 \%$ vão das usinas aos 
centros armazenadores primários, localizados em 10 pontos do Estado e os restantes $11,4 \%$ vão diretamente das usinas até Paulínia onde está instalado o centro armazenador secundário.

A distância percorrida das usinas a cada centro armazenador primário foi fornecida pelo setor de programação de álcool da Petrobrás e o valor médio calculado, ida e volta, $133 \mathrm{~km}$, é a média ponderada entre as distâncias de cada centro armazenador primário às usinas e o volume de álcool etílico transportado, tabela E.2.

TABELA E.2 Distância média percorrida, ida e volta, por rodovia, de usinas aos centros armazenadores primários, no Estado de São Paulo em 1991

\begin{tabular}{lcc}
\hline Centros Coletores & $\begin{array}{c}\text { Volume transportado } \\
{\left[\mathrm{mil} \mathrm{m}^{3}\right]}\end{array}$ & $\begin{array}{c}\text { Distância média percorrida } \\
{[\mathrm{km}]}\end{array}$ \\
\hline Sertãozinho & 523,9 & 78 \\
Ribeirão Preto & 472,5 & 178 \\
S.J. do Rio Preto & 85,2 & 189 \\
Santa Adélia & 366,9 & 97 \\
Araraquara & 392,5 & 106 \\
Bauru & 346,1 & 168 \\
Ourinhos & 57,7 & 324 \\
Nova Avanhandava & 40,3 & 222 \\
\hline Total & $2.285,1$ & 133 \\
\hline
\end{tabular}

Fonte: FERREIRA (1994).

No transporte das usinas ao centro armazenador secundário, as distâncias envolvidas são maiores. Os veículos que o realizam saem de Paulínia vazios ou carregados com outro combustível, gasolina ou óleo diesel, e voltam transportando álcool. O valor encontrado, $433 \mathrm{~km}$, também é obtido através da média ponderada entre as distâncias das usinas ao centro armazenador secundário e o volume transportado, tabela E.3.

Praticamente todo álcool armazenado nos centros primários é transportado por ferrovia até o centro armazenador secundário em Paulínia, apenas 1,6\% do álcool armazenado em centros primários é transportado por hidrovia. 
TABELA E.3 Distância média percorrida, ida e volta, por rodovia, de usinas ao centro armazenador secundário, no Estado de São Paulo em 1991

\begin{tabular}{lcc}
\hline Centros Coletores & $\begin{array}{c}\text { Volume transportado } \\
{\left[\mathrm{mil} \mathrm{m}^{3}\right]}\end{array}$ & $\begin{array}{c}\text { Distância média percorrida } \\
{[\mathrm{km}]}\end{array}$ \\
\hline Sertãozinho & 53,5 & 540 \\
Ribeirão Preto & 44,9 & 414 \\
Santa Adélia & 0,1 & 556 \\
Araraquara & 121,6 & 382 \\
Bauru & 110,8 & 528 \\
Sta. Maria da Serra & 40,3 & 286 \\
Paulínia & 580,8 & 428 \\
\hline Total & 952,0 & 433 \\
\hline
\end{tabular}

Fonte: FERREIRA (1994).

Segundo ARANHA (1994) da divisão de estudos hidroviários da Cesp, em 1991 foram transportadas pela hidrovia Tietê-Paraná 32,6 mil toneladas de álcool hidratado, o que corresponde a 40,3 $\mathrm{mil} \mathrm{m}^{3}$.

Devido a problemas de contaminação do produto o transporte de álcool anidro não é realizado por hidrovia.

O escoamento de parte da produção de álcool da região Noroeste do Estado pela hidrovia inicia-se no centro armazenador primário em Nova Avanhandava, percorre $334 \mathrm{~km}$ pelo rio Tietê até Santa Maria da Serra, próximo a Piracicaba. A partir de Santa Maria da Serra, o álcool é transportado até a Replan, através de caminhões, por $143 \mathrm{~km}$, e as chatas que trouxeram álcool retornam à Nova Avanhandava carregadas de gasolina ou óleo diesel.

Por ferrovia são transportados cerca de $32 \%$ do álcool produzido no Estado de São Paulo. Deste total, 3\% são exportados para outros Estados, 9,5\% são transportados por locomotivas com tração elétrica e os restantes $19,5 \%$ por locomotivas com tração diesel.

O cálculo da distância média percorrida considera o tipo de tração. O resultado obtido é a média ponderada entre a distância dos centros coletores primários 
até Paulínia e o volume de álcool transportado, tabela E.4. As distâncias consideradas são só de ida, pois na volta os trens voltam carregados com outros combustíveis.

A Usina São Martinho, proprietária do centro coletor em Pradópolis, escoa diretamente a sua produção de álcool por ferrovia até Paulínia, evitando assim o armazenamento em um centro armazenador primário.

TABELA E.4 Distância média percorrida, só ida, em ferrovia por tipo de tração, de centros armazenadores primários ao centro armazenador secundário, no Estado de São Paulo em 1991

\begin{tabular}{lccc}
\hline Centros Coletores & $\begin{array}{c}\text { Volume transportado } \\
{\left[\mathrm{mil} \mathrm{m}^{3}\right]}\end{array}$ & $\begin{array}{c}\text { Distância média } \\
\text { percorrida }[\mathrm{km}]\end{array}$ & Tipo de tração \\
\hline Sertãozinho & 523,9 & 314 & diesel \\
Ribeirão Preto & 472,5 & 282 & diesel \\
S.J. do Rio Preto & 85,2 & 416 & diesel \\
Santa Adélia & 366,9 & 331 & diesel \\
Pradópolis & 220,2 & 282 & diesel \\
Araraquara & 392,5 & 215 & elétrica \\
Bauru & 346,1 & 301 & elétrica \\
Ourinhos & 57,7 & 508 & elétrica \\
\hline Total & & & \\
Diesel & $1.668,7$ & 310 & \\
Elétrica & 796,3 & 274 & \\
\hline
\end{tabular}

Fonte: SANTOS (1994).

Do centro armazenador secundário, em Paulínia, o álcool é transportado por dutos até uma das bases da Petrobrás localizadas em Utinga, Barueri, Guarulhos, Santos, São José dos Campos e Rio de Janeiro.

Nos grandes centros consumidores as companhias distribuidoras recebem o álcool da Petrobrás através de dutos ou caminhões e distribuem aos postos de combustíveis.

Segundo GUERRIERO (1993) da divisão de petróleo da Shell do Brasil S.A., a distribuição dos combustíveis na Grande São Paulo é realizada por oito 
companhias: Atlantic, Esso, Hudson, Ipiranga, Petrobrás, São Paulo, Shell e Texaco. A Petrobrás e a Shell distribuem, juntas, $60 \%$ do combustível comercializado na Grande São Paulo e os restantes $40 \%$ são divididos entre as demais companhias.

Os veículos utilizados pela Shell na distribuição de combustíveis são caminhões com capacidades que variam entre 10 e $32 \mathrm{~m}^{3}$. Estes caminhões transportam, em média, $20 \%$ de óleo diesel, $35 \%$ de álcool hidratado e $45 \%$ de gasolina. No volume transportado de gasolina, $21 \%$, em média, correspondem a álcool anidro.

A média ponderada entre o volume transportado e a quantidade de veículos existentes na frota, fornece a distribuição por tipo de veículo. Supôs-se que os caminhões são utilizados com a mesma freqüência.

TABELA E.5 Distribuição dos caminhões da Shell utilizados em entrega de combustíveis das bases aos postos de combustíveis na Grande São Paulo

\begin{tabular}{lccc}
\hline Caminhões & $\begin{array}{c}\text { Volume } \\
{\left[\mathrm{m}^{3}\right]}\end{array}$ & $\begin{array}{c}\text { Quantidade } \\
\text { na frota }\end{array}$ & $\begin{array}{c}\% \\
\text { na frota }\end{array}$ \\
\hline Pequenos & 10 & 4 & 8,13 \\
Médios & 12 & 25 & \\
& 18 & 80 & 64,32 \\
& 22 & 35 & \\
Grandes & 24 & 20 & \\
\hline Total & 32 & 36 & 27,55 \\
\hline
\end{tabular}

Fonte: GUERRIERO (1993).

Os valores encontrados são relativos à frota da Shell na Grande São Paulo e são utilizados como referência para o trabalho devido a inexistência de dados que abranjam o Estado de São Paulo.

O extrato do transporte de álcool por modal para o Estado de São Paulo em 1991 é mostrado na tabela E.6. 
TABELA E.6 Distribuição do transporte de álcool por modal para o Estado de São Paulo em 1991

\begin{tabular}{|c|c|c|c|c|c|}
\hline & \multicolumn{2}{|c|}{ Álcool Anidro } & \multicolumn{2}{|c|}{ Álcool Hidratado } \\
\hline & & $\mathrm{mil} \mathrm{m}^{3}$ & $\%$ & $\mathrm{mil} \mathrm{m}^{3}$ & $\%$ \\
\hline \multicolumn{2}{|l|}{ Produção } & $1.526,1$ & 100,00 & $7,013,9$ & 100,00 \\
\hline \multicolumn{2}{|c|}{ Transporte rodoviário } & 634,3 & 41,56 & $1.898,1$ & 27,06 \\
\hline \multicolumn{2}{|c|}{ Armazenamento Primário } & 634,3 & 41,56 & $1.898,1$ & 27,06 \\
\hline \multicolumn{6}{|l|}{ Transporte } \\
\hline Rodoviário & & 207,8 & 13,62 & 770,5 & 10,99 \\
\hline \multirow{2}{*}{ Ferroviário } & tração diesel & 250,5 & 16,41 & $1.418,1$ & 20,22 \\
\hline & tração elétrica & 194,1 & 12,72 & 602,0 & 8,58 \\
\hline \multicolumn{2}{|c|}{ Hidroviário } & 0,0 & 0,00 & 40,3 & 0,57 \\
\hline \multicolumn{2}{|c|}{$\begin{array}{l}\text { Armazenamento } \\
\text { secundário }\end{array}$} & 652,4 & 42,75 & $2.830,9$ & 40,36 \\
\hline \multicolumn{6}{|c|}{ Distribuição } \\
\hline \multirow[t]{3}{*}{ Caminhão } & pequeno & 53,7 & 3,52 & 333,8 & 4,76 \\
\hline & médio & 425,2 & 27,86 & $2.640,9$ & 37,65 \\
\hline & grande & 182,1 & 11,93 & $1.131,2$ & 16,13 \\
\hline \multicolumn{2}{|l|}{ Exportação } & 653,1 & 42,80 & $2.808,1$ & 40,04 \\
\hline \multicolumn{2}{|l|}{ Perdas } & 212,0 & 13,89 & 99,9 & 1,42 \\
\hline
\end{tabular}

Devido a falta de informações que permitissem distribuir as perdas durante cada fase de transporte, elas foram consideradas na fase de entrega do produto aos postos de combustíveis. 


\section{REFERÊNCIAS BIBLIOGRÁFICAS E COMUNICAÇÕES PESSOAIS}

AIAA. Etanol, fonte de energia para a sociedade auto-sustentável, Rio de Janeiro, 1992, $35 \mathrm{p}$.

ACKERMANN, Helgo. Setor de tecnologia de processos de açúcar da Copersucar, comunicação pessoal em 20.01.1995.

ARAÚJO, João L. R. H. Modelos de energia para planejamento. Tese para o concurso de professor titular. Universidade Federal do Rio de Janeiro, 1988. $140 \mathrm{p}$.

ARANHA, Sylla Benedicto Abibe. Divisão de estudos hidroviários da Cesp, comunicação pessoal em 29.04.1994.

BICALHO, Ronaldo G. Reflexões críticas sobre o balanço energético brasileiro. Tese de mestrado. Universidade Federal do Rio de Janeiro, 1986. 151 p.

BRASIL. Ministério da Indústria e do Comércio. Instituto do Açúcar e do Álcool. Planalsucar. Subsídios para fixação dos preços da cana-de-açúcar, do açúcar e do álcool safra 1985 - 1986. Piracicaba, Convênio IAA/FGV/IBRE, s/d. 153 p.

BRASIL. Ministério da Indústria e do Comércio. Instituto do Açúcar e do Álcool. Planalsucar. Manual de orientação: cultura da cana-de-açúcar. Piracicaba, Instituto do açúcar e do álcool, 1986. 56 p.

BRASIL. Ministério de Minas e Energia. Plano nacional de energia elétrica 1993/2015. Rio de Janeiro, Centrais Elétricas Brasileiras S.A. - Eletrobrás, 1994. v. 1, 97 p.

BROUWER, Floor. Integrated environmental modelling: desing and tools. Dordrecht, The Netherlands. Martinus Nijhoff Publishers, 1987. 223 p.

CARTA DA ANFAVEA. Boletim mensal da associação nacional dos fabricantes de veículos automotores. São Paulo. Anfavea. oㅜ 104, jan. 1995.

CAVALCANTI, Joadelivio Amorim. Gerência de área de programas comerciais da Agência para Aplicação de Energia, comunicação pessoal em 25.10.1994.

COPERSUCAR. Custos de produção de cana, acúcar e álcool, safra 1978-79. São Paulo, Copersucar, 1978. 54 p.

COPERSUCAR. Proálcool: fundamentos e perspectivas. 2.ed., rev. São Paulo, Copersucar, 1989(b). $121 \mathrm{p}$. 
CUNHA, Renato P. P. et alii. Energia e meio ambiente - uma abordagem sistêmica. In: I CONGRESSO BRASILEIRO DE PLANEJAMENTO ENERGÉTICO. Campinas. 1989. Anais. v.4. São Paulo, Unicamp, 1989. p. 397-406.

DIJK, Daan; KOK, Matthijs. A comparison of different modelling approaches to strategic energy planning. European Journal of Operational Research, NorthHolland, (29): 42-50, 1987.

ENCARNAÇÃO JR., Genserico. Planejamento do setor petróleo no Brasil. In: I CONGRESSO BRASILEIRO DE PLANEJAMENTO ENERGÉTICO. Campinas. 1989. Anais. v.3. São Paulo, Unicamp, 1989. p. 53-65.

ENNES, Sérgio Augusto Weigert. Setor de balanço energético da Cesp, comunicação pessoal em 10.06.1994.

ERBER, Pietro. Integração dos planejamentos energéticos, nacional e regional. In: I CONGRESSO BRASILEIRO DE PLANEJAMENTO ENERGÉTICO. Campinas. 1989. Anais. v.1. São Paulo, Unicamp, 1989. p. 147-64.

EUROPLAN. Energy impact model - a computer model analyzing and forecasting environmental and economic impacts of energy systems. Sophia, France, s/d. 12 p. Datilografado.

FERREIRA, Mauri Bosquê. Setor de programação de álcool da Petrobrás, comunicação pessoal em 18.02.1993 e 11.05.1994.

FERREIRA, André L.; BAJAY, Sérgio V. Proálcool: do discurso da renovabilidade àsua dependência de uma fonte não renovável de energia. In: I CONGRESSO BRASILEIRO DE PLANEJAMENTO ENERGÉTICO. Campinas. 1989. Anais. v.3. São Paulo, Unicamp, 1989 (a). p. 351-65.

FERREIRA, José J. A. Seleção e especificação de modelos para planejamento energético. In: LA ROVERE, Emilio L. \& ROBERT, Marcelo (edit.). Capacitação para a tomada de decisões na área de energia - planejamento energético: elementos para um novo enfoque. Montevidéu, FINEP-UNESCO, 1989 (b). p. 169-90.

GOLDEMBERG, J. et alii. Cenários de demanda e investimentos em energia para o ano 2000 no Estado de São Paulo. São Paulo, Cesp, 1986. 54 p.

GOLDEMBERG, J. et alii. Energia para o desenvolvimento. São Paulo, T. A. Queiroz, 1988. $101 \mathrm{p}$.

GUERRIERO, Miguel Tadeo. Divisão de petróleo da Grande São Paulo da Shell, comunicação pessoal em 15.06.1993.

INNOTEC SYSTEMANALYSE. Energy flow model for the member states of the European Community. Berlim, InnoTec Systemanalyse, 1987. $110 \mathrm{p}$. 
INNOTEC SYSTEMANALYSE. Energy flow analyses for all member states of OLADE. Berlim, InnoTec Systemanalyse, s/d. $32 \mathrm{p}$.

INSTITUTO DE PESQUISAS TECNOLÓGICAS DO ESTADO DE SÃO PAULO. Perspectivas de mudanças no custo de produção do álcool de cana no Estado de São Paulo. São Paulo. IPT, 1986. 207 p.

JANNUZZI, Gilberto De M. Conservação de energia, meio ambiente e desenvolvimento. Tese para o concurso de livre-docência. Universidade Estadual de Campinas, 1991. $100 \mathrm{p}$.

KAVRAK, Ibrahim. A model for national energy planning. In: INTERNATIONAL FEDERATION OF AUTOMATIC CONTROL SYMPOSIUM. Kyoto, Japan. 1977. Proceedings. Environmental systems planning, desing and control. v. 2. A. Wheaton \& Co. Ltd, Great Britain, 1978. p. 789-92.

KOLLER, Helmut Wintsus. Setor de mecanização agrícola da Copersucar, comunicação pessoal em 08.03.1993.

KOURIS, George. Energy consumption and economic activity in industrialized economies - a note. Energy Economics, London, 5 (3): 207-12, oct. 1983(a).

KOURIS, George. Fuel consumption for road transport in the USA. Energy Economics, London, 5 (2): 89-99, apr. 1983(b).

LAKSHMANAN, T. R. A multiregional model of the economy, environment, and energy demand in the United States. Economic Geography, Massachusetts, 59 (3): 296-320, jul. 1983.

LAPILLONNE, B. et alii. Energy models. In: DESAI, Ashok V. (edit.). Energy planning - models, information systems, research and development. New Delhi, Wiley Eastern Limited, 1990, p.10-32.

LAVERGNE, Jean-Guy D. Energy modelling in developing countries. In: DESAI, Ashok V. (edit.). Energy planning - models, information systems, research and development. New Delhi, Wiley Eastern Limited, 1990, p.33-55.

LODI, Geraldo. Divisão de vendas de outros produtos da cana-de-açúcar da Copersucar, comunicação pessoal em 16.06.1994.

LOPES, Eduardo. Departamento de estatísticas da Anfavea, comunicação pessoal em 20.10.1994.

MACEDO, Isaías C.; NOGUEIRA, L. A. Horta. Balanço de energia na produção de cana-de-açúcar e álcool nas usinas cooperadas. Boletim Técnico Copersucar, São Paulo (31): 22-33, jul. 1985.

MACEDO, Isaías C. Agroindústria da cana-de-açúcar: participação na redução da taxa de carbono atmosférico no Brasil. Informativo do Centro de Tecnologia Copersucar, Piracicaba (67): 1-4, nov. 1991. 
MARQUES, José Carlos. Assessoria de planejamento e economia da Copersucar, comunicação pessoal em 10.05.1994.

MEIER, Peter. Energy systems analysis for developing countries. In: Lecture notes in economics and mathematical systems. Berlin, Germany. SpringerVerlag Heidelberg, 1984. $344 \mathrm{p}$.

MONACO, Lourival C. Planejamento integrado e variáveis que afetam oferta e demanda. In: I CONGRESSO BRASILEIRO DE PLANEJAMENTO ENERGÉTICO. Campinas. 1989. Anais. v.1. São Paulo, Unicamp, 1989. p. 111-33.

MUNHOZ, Valtemir Cruz. Conselho de administração das empresas de energia do Estado de São Paulo, comunicação pessoal em 21.05.1993.

MURGEL, E. M. et alii. Inventário de emissão veicular - metodologia de cálculo. Engenharia Sanitária, Rio de Janeiro, 26 (3): 292-96, jul/set. 1987.

MYOKEN, Hajime. International environmental policies in interdependent economy under decentralized control. In: INTERNATIONAL FEDERATION OF AUTOMATIC CONTROL SYMPOSIUM. Kyoto, Japan. 1977. Proceedings. Environmental systems planning, desing and control. v. 2. A. Wheaton \& Co.Ltd, Great Britain, 1978. p. 793-99.

NIJKAMP, Peter; VOLWAHSEN, Andreas. New directions in integrated regional energy planning. Energy Policy, W. Sussex, 18 (8): 764-73, oct. 1990.

NOBREGA, Diana. Departamento de planejamento e economia da associação das indústrias de açúcar e álcool do Estado de São Paulo, comunicação pessoal em 23.06.1994.

NORONHA, Astolfo Carlos Quintella. Divisão de estudos hidroviários da Cesp, comunicação pessoal em 25.03.1993.

ORGANIZATION FOR ECONOMIC COOPERATION AND DEVELOPMENT. Energy balances of OECD countries, 1980 - 1989. Paris. International Energy Agency, 1991(a). $450 \mathrm{p}$.

ORGANIZATION FOR ECONOMIC COOPERATION AND DEVELOPMENT. Energy statistics and balances of non-OECD countries, 1989 - 1990. Paris. International Energy Agency, 1992(b). 417 p.

ORGANIZATION FOR ECONOMIC COOPERATION AND DEVELOPMENT. National inventories of net greenhouses gas emissions - IPCC guidelines for preparation and reporting. Simplified workbook and software. Paris, France, v.1, OECD, 1992(c).

PAKRAVAN, Karim. Exhaustible resource models and predictions of crude oil prices - some preliminary results. Energy Economics, London, 3 (3): 169-77, jul. 1981. 
PATUSCO, João A.M. "Memória" dos estudos prospectivos de energia no Brasil. Brasília, Ministério de Minas e Energia, s/d. 18 p. Datilografado.

PATUSCO, João A.M. Nova proposta de tratamento da cana-de-acúcar e seus subprodutos na metodologia do balanço energético nacional. Brasília, Ministério de Minas e Energia, 1985. 18 p. Datilografado.

PYNDICK, Robert S. Models of resource markets and the explanation of resource price behaviour. Energy Economics, London, 3 (3): 130-37, jul. 1981.

RELATÓRIO da comissão constituída através do Decreto n099.503, de 02.09.90. Reexame da matriz energética nacional. Brasília, 1991. 20 p.

REUTER, A.; VOSS A. Tools for energy planning in developing countries. Energy, Great Britain, 15 (7/8): 705-14, 1990.

SAMOUILIDIS, J-Emmanuel; MITROPOULOS, Costas S. Energy and economic growth in industrializing countries - the case of Greece. Energy Economics, London, 6 (3): 191-201, jul. 1984.

SANTOS Jr., José Romeu dos. Coordenadoria de ação comercial - líquidos da Fepasa, comunicação pessoal em 05.04.1993 e 06.05.1994.

SANTAELLA, Miguel. Setor de manejo agrícola da Copersucar, comunicação pessoal em 27.11.1992 e 27.10.1994.

SÃO PAULO. Cesp. Departamento de Planejamento do Sistema Elétrico. MEDEE/C - Metodologia e aplicação para a demanda de energia - Brasil 19952000. São Paulo, Cesp, 1990. 81 p.

SÃO PAULO. Cesp. Departamento de Planejamento do Sistema Elétrico. MEDEE/C - Metodologia e aplicação para a demanda de energia do Estado de São Paulo - 2000. São Paulo, Cesp, 1991(a). 131 p.

SÃO PAULO. Cesp. Departamento de Planejamento e Desenvolvimento Energético. Balanço energético do Estado de São Paulo, 1989 - ano base 1988. São Paulo, Cesp, 1991 (b). 167 p.

SÃO PAULO. Cesp. Departamento de Planejamento e Desenvolvimento Energético. Balanço energético do Estado de São Paulo, 1990 - ano base 1989. São Paulo, Cesp, 1992(a). 122 p.

SÃO PAULO. Cesp. Departamento de Planejamento e Desenvolvimento Energético. Balanço energético do Estado de São Paulo, 1991 - ano base 1990. São Paulo, Cesp, 1993(a). 143 p.

SÃO PAULO. Cetesb. Controle da poluição veicular no Brasil. São Paulo, Cetesb, 1992(b). 23 p. 
SÃO PAULO. Cetesb. Relatório de qualidade do ar no Estado de São Paulo 1992. São Paulo, Cetesb, 1993(b). 120 p.

SÃO PAULO. Grupo Técnico de Estudos do Álcool. Conselho de Administração. Informe conjuntural. São Paulo, Conselho de Administração, jan. 1993(c).

SECRETARIA DO MEIO AMBIENTE. Coordenadoria de Planejamento Ambiental. Estudo de impacto ambiental - EIA, Relatório de impacto ambiental - RIMA: Manual de orientação. São Paulo, 1991. 30 p.

SEIXAS, Maria J.; MARTINS, V. A utilização da programação linear em modelos de energia e ambiente - aplicação a Portugal. Lisboa, Portugal, Universidade Nova de Lisboa. s/d. 10 p. Datilografado.

UNITED STATES OF AMERICAN. Environmental Protection Agency. Office of Air and Radiation. Compilation of air pollutant emission factors: stationary sources, vol. 1, 4. ed., Washington, U. S. Government Printing Office, 1985(a).

UNITED STATES OF AMERICAN. Environmental Protection Agency. Office of Air and Radiation. Compilation of air pollutant emission factors: mobile sources, vol. 2, 4. ed., Washington, U. S. Government Printing Office, 1985(b).

VOLF, Peter Eric. Centro de pesquisas ferroviárias da Fepasa, comunicação pessoal em 06.05.1994.

WANDERLEY, V. M. Balanço de energia útil - experiência do Brasil. In: IX SEMINÁRIO NACIONAL DE PRODUCCÃO E TRANSMISSÃO DE ENERGIA ELÉTRICA. Belo Horizonte. 1987. Anais. Planejamento de sistemas elétricos. grupo VII. Belo Horizonte, Companhia Energética de Minas Gerais, 1987. $\mathrm{BH} / \mathrm{GPL} / 17$. 


\section{BIBLIOGRAFIA RECOMENDADA}

ALLEN, Edward L. et alii. A comparative analysis of global energy models. Oak Ridge, Institute for Energy Analysis, 1979. 42 p.

ALVES, Roberto do C. et alii. A política de preços dos derivados de petróleo no Brasil no início dos anos 90. In: VI CONGRESSO BRASILEIRO DE ENERGIA. Rio de Janeiro. 1993. Anais. v.II. Rio de Janeiro, UFRJ, 1993. p. 525-31.

ANFAVEA. Associação Nacional dos fabricantes de veículos automotores. Anuário estatístico - 1957/1990. São Paulo. Anfavea, 1991. 111 p.

ANFAVEA. Associação Nacional dos fabricantes de veículos automotores. Anuário estatístico - 1957/1993. São Paulo. Anfavea, 1994. 122 p.

BAJAY, Sérgio V. Planejamento energético: necessidade, objetivo e metodologia. Revista Brasileira de Energia, Campinas, 1 (1): 45-53, 1989.

BAJAY, Sérgio V.; BERNI, Mauro D. Transporte urbano: planejamento energético e ambiental. In: VI CONGRESSO BRASILEIRO DE ENERGIA. Rio de Janeiro. 1993. Anais. v.II. Rio de Janeiro, UFRJ, 1993. p. 389-95.

BARONE, Jussara C.; BAJAY, Sérgio V. O balanço energético regional como instrumento de planejamento. In: I CONGRESSO BRASILEIRO DE PLANEJAMENTO ENERGÉTICO. Campinas. 1989. Anais. v.4. São Paulo, Unicamp, 1989. p. 201-21.

BAUGHMAN, Martin L. A model for energy - environment systems analyses: struture and uses. Energy Policy, W. Sussex, special publication: 134-48, oct. 1973.

BORGES, Júlio M. M. Custos, preços e competitividade do álcool combustível. Revista Brasileira de Energia, Campinas, 2 (2): 163-75, 1992.

BORGES, Júlio M. M.; ARBEX, Jorge G. Cana-de-açúcar e energia. Revista Brasileira de Energia, Campinas, 3 (2): 107-15, 1994.

BRASIL. Ministério de Minas e Energia. Balanço energético nacional, 1992 ano base 1991. Brasília, Ministério de Minas e Energia, 1992. 140 p.

BRASIL. Ministério de Minas e Energia. Plano nacional de energia elétrica 1987/2010. Rio de Janeiro, Centrais Elétricas Brasileiras S.A. - Eletrobrás, 1987(a). 270 p.

BRASIL. Ministério dos Transportes. Anuário estatístico dos transportes, 1987. Brasília, Geipot, 1987(b). 694 p. 
BUSSE, Adolpho G. et alii. O sistema energético de referência: concepção, construção e aplicação. In: I CONGRESSO BRASILEIRO DE PLANEJAMENTO ENERGÉTICO. Campinas. 1989. Anais. v.4. São Paulo, Unicamp, 1989. p. 427-40.

CASTRO, Moacyr. Queimada da cana não afeta qualidade do ar, diz pesquisa. O Estado de São Paulo, 29-11-92, p.13, 1-3 col.

COPERSUCAR. Álcool, combustível limpo e renovável. São Paulo, Copersucar, s/d(a). $16 \mathrm{p}$.

COPERSUCAR. Cana, açúcar e álcool: a energia que vem do sol. Revista Nova Escola, São Paulo, 32: encarte, 1989(a).

COPERSUCAR. Relatório anual 1991/1992. São Paulo, Copersucar, 1992. 45 p.

COPERSUCAR. Relatório anual 1992/1993. São Paulo, Copersucar, 1993. 40 p.

COPERSUCAR. The sugar cane agroindustry: a profile. São Paulo, Copersucar, s/d(b). $28 \mathrm{p}$.

DERISIO, José C. Introdução ao controle de poluição ambiental. São Paulo, Cetesb, 1992. $201 \mathrm{p}$.

ELECTRIC POWER RESEARCH INSTITUTE. Stanford pilot energy/economic model. Palo Alto, Electric Power Research Institute, 1978. 41 p.

FERNANDES, Eliana S.L. A poluição atmosférica em centros urbanos. São Paulo, Instituto de Eletrotécnica e Energia, USP. s/d. 9 p. Datilografado.

GUIMARÃES, Odilon; CARVALHO, Patrícia. Eletricidade vegetal. Globo Rural Economia, Rio de Janeiro, 8 (81): 4-14, jul. 1992.

INFORMAÇÃO SOBRE O USO RACIONAL DE ENERGIA. São Paulo. Agência para aplicação de energia. ano 6, № 29, abr./maio 1993.

INFORMAÇÃO SOBRE O USO RACIONAL DE ENERGIA. São Paulo. Agência para aplicação de energia. ano 7, no 30, mar./abr. 1994(a).

INFORMAÇÃO SOBRE O USO RACIONAL DE ENERGIA. São Paulo. Agência para aplicação de energia. ano 7, № 31, maio/jun. 1994(b).

INFORMAÇÃO SOBRE O USO RACIONAL DE ENERGIA. São Paulo. Agência para aplicação de energia. ano 7, no 32, jul./ago. 1994(c).

JANNUZZI, Gilberto De M. Conservação de energia, meio ambiente e desenvolvimento. Ciência Hoje, Rio de Janeiro, 11 (66): 16-22, set. 1990. 
JOHN, Liana. Máquina revoluciona colheita de cana crúa. Suplemento Agrícola, 1 (1933): 12-13, 25-11-1992.

KIRCHHOFF, V. W. J. H. et alii. Enhancements of $\mathrm{CO}$ and $\mathrm{O}_{3}$ from burnings in sugar cane fields. Journal of Atmospheric Chemistry, Dordrecht, The Netherlands, 12: 87-102. 1991.

KOFFLER, Natalio F. et alii. Inventário canavieiro com auxílio de fotografias aéreas - a grande região de Piracicaba no ano-safra 1978/79. Boletim Técnico Planalsucar, série A, Piracicaba 1 (2): 3-38, dez. 1979.

LABYS, Walter C. Evaluation of models. Energy, Great Britain, 15 (3/4): 15562, 1990.

LOPES, Renato S. Planejamento energético integrado para o desenvolvimento das unidades da federação e nacional. In: I CONGRESSO BRASILEIRO DE PLANEJAMENTO ENERGÉTICO. Campinas. 1989. Anais. v.1. São Paulo, Unicamp, 1989. p. 165-83.

MALLET, Sinclair; GUERRA, Guy. Emissão de $\mathrm{CO}_{2}$ - o uso de energia renovável como forma de redução. In: VI CONGRESSO BRASILEIRO DE ENERGIA. Rio de Janeiro. 1993. Anais. v.II. Rio de Janeiro, UFRJ, 1993. p. 723-29.

MIYAMOTO, Akio et alii. Integração do planejamento energético. In: I CONGRESSO BRASILEIRO DE PLANEJAMENTO ENERGÉTICO. Campinas. 1989. Anais. v.4. São Paulo, Unicamp, 1989. p. 37-47.

MONTEIRO, Marco A. G. et alii. Plano energético integrado para Minas Gerais. In: VI CONGRESSO BRASILEIRO DE ENERGIA. Rio de Janeiro. 1993. Anais. v.II. Rio de Janeiro, UFRJ, 1993. p. 593-98.

MOULIK, T. K. et alii. Energy planning in India. Energy Policy, W. Sussex, 20 (9): 836-46, sep. 1992.

NEGRI, Jean C.; MOREIRA, José R. Methanol use - the Brasilian experience. In: IX INTERNATIONAL SYMPOSIUM ON ALCOHOL FUELS. Firenze, Italy. 1991. Proceedings. v.9. Firenze, 1991. p. 1034-39.

NOSSO futuro comum, Comissão mundial sobre meio ambiente e desenvolvimento, 2.ed., Rio de Janeiro, Fundação Getulio Vargas, 1991. 430 p.

NYENZI, B. S. Overview of $\mathrm{CO}_{2}$ from energy and industry. In: LATIN AMERICAN REGIONAL WORKSHOP FOR ESTIMATING NATIONAL GHG EMISSION. S. J. dos Campos, Brasil. 1993. Proceedings. National Institute for Space Research (INPE), 1993.

O VALOR energético da cana. Folha de São Paulo, 22-01-91, cad. G, p.3, 1-3 col. 
ORGANIZATION FOR ECONOMIC COOPERATION AND DEVELOPMENT. Energy balances of OECD countries, 1987 - 1988. Paris. International Energy Agency, 1990. $232 \mathrm{p}$.

ORGANIZATION FOR ECONOMIC COOPERATION AND DEVELOPMENT. Energy statistics of OECD countries, 1989 - 1990. Paris. International Energy Agency, 1992(a). 263 p.

ORGANIZATION FOR ECONOMIC COOPERATION AND DEVELOPMENT. Fuel efficiency of passenger cars. Paris. International Energy Agency, 1991 (b). $91 \mathrm{p}$.

PATUSCO, João A.M. Tratamento da cana-de-acúcar no BEN. Brasília, Ministério de Minas e Energia, 1988. 3 p. Datilografado.

PEREIRA JR., Ivan de Sá; IACHAN, Roberto. Planejamento operacional do abastecimento da Petrobrás. In: VI CONGRESSO BRASILEIRO DE ENERGIA. Rio de Janeiro. 1993. Anais. v.II. Rio de Janeiro, UFRJ, 1993. p. 477-80.

PERKINS, Henry C. Air pollution. New York, McGraw-Hill, 1974. 407 p.

REDDY, Amulya K. N. Development, energy and environment. S.J.Patwardhan, Secretary Parisar, 1991. $51 \mathrm{p}$.

RODRIGUES, Otávio. Respirando dinossauros - as quadrilhas da fumaça continuam invadindo o dia-a-dia nos grandes centros. Caminhos da terra, São Paulo, 2 (6): 10-11, 1994.

SAMOUILIDIS, J-Emmanuel; MITROPOULOS, Costas S. Energy investment and economic growth. Energy Economics, London, 5 (4): 237-46, oct. 1983.

SÃO PAULO. Cesp. Departamento de Planejamento e Desenvolvimento Energético. Sinopse do balanço energético do Estado de São Paulo, 1993 ano base 1992. São Paulo, Cesp, 1994(a). 25 p.

SÃO PAULO. Cesp. Divisão de Estudos Múltiplos. Estudo para implantação da navegação nos rios Paraná e Tietê. São Paulo, Cesp, 1985. 263 p.

SÃO PAULO. Conselho Estadual de Energia. Pesquisa de mercado do álcool de cana produzido no Estado de São Paulo. São Paulo, Conselho Estadual de Energia, 1987. $155 \mathrm{p}$.

SÃO PAULO. Grupo Técnico de Estudos do Álcool. Conselho de Administração. Boletim informativo sobre o setor energético e sucro-alcooleiro. São Paulo, Conselho de Administração, maio 1994(b).

SINÍCIO, Marcos F. Demanda e conservação de energéticos nas usinas de açúcar e álcool paulistas. Tese de mestrado. Universidade Estadual de Campinas, 1992. $260 \mathrm{p}$. 
STATISTICAL OFFICE OF THE EUROPEAN COMMUNITIES. Energy Division. Principles and methods of the energy balance sheets. s/l. Eurostat. 1982. $37 \mathrm{p}$.

UNITED NATIONS. Department of International Economic and Social Affairs. Statistical Office. Concepts and methods in energy statistics, with special reference to energy accounts and balances. New York, United Nations Publication, 1982. $156 \mathrm{p}$.

WALTER, Arnaldo C. S. et alii. Cogeração e produção independente de eletricidade nas usinas de açúcar e álcool: sua viabilidade segundo a ótica dos diferentes atores envolvidos. In: VI CONGRESSO BRASILEIRO DE ENERGIA. Rio de Janeiro. 1993. Anais. v.ll. Rio de Janeiro, UFRJ, 1993. p. 731-37.

WILSON, Deborah. Quantifying and comparing fuel cycle greenhouse-gas emissions. Energy Policy, W. Sussex, 18 (6): 550-62, jul/aug. 1990.

ZILBERMAN, Isaac. O balanço energético e o planejamento. In: LA ROVERE, Emilio L. \& ROBERT, Marcelo (edit.). Capacitação para a tomada de decisões na área de energia - planejamento energético: elementos para um novo enfoque. Montevidéu, FINEP-UNESCO, 1989. p. 139-67.

ZYLBERSZTAJN, David; COELHO, Suani T. An economic evaluation of sugar cane use for electricity production and its environmental consequences on avoided carbon emission in Brazil. São Paulo, Instituto de Eletrotécnica e Energia, Universidade de São Paulo, 1991. 12 p. Datilografado. 
Apêndice I - Unidade, tabelas de conversão, preços e quantidade de energia

Para se expressarem os fluxos que formam o balanço energético e a fim de agregar as distintas variáveis, deve-se adotar uma única unidade.

A unidade deste estudo é o Joule ( $\mathrm{J}$ ) pois pertence ao Sistema Internacional de unidades e expressa com fidelidade a realidade física do que significa.

A seguir foram preparadas tabelas que são utilizadas na conversão de unidades e na elaboração e conversão dos coeficientes de impactos, a saber, emissões, custos e consumo de energia.

TABELA I.1 Multiplicadores de base decimal

\begin{tabular}{|l|c|c|}
\hline Quilo & $\mathrm{k}$ & $10^{3}$ \\
\hline Mega & $\mathrm{M}$ & $10^{6}$ \\
\hline Giga & $\mathrm{G}$ & $10^{9}$ \\
\hline
\end{tabular}

TABELA I.2 Fatores de conversão de unidades

\begin{tabular}{|c|c|c|c|c|}
\hline & \multicolumn{3}{|c|}{ saída } \\
\hline & & $\mathrm{kJ}$ & $\mathrm{kWh}$ & $\mathrm{kcal}$ \\
\hline \multirow{3}{*}{$\begin{array}{l}\text { entrad } \\
\text { a }\end{array}$} & $1 \mathrm{~kJ}$ & 1 & $0,278 \cdot 10^{-3}$ & 0,2388 \\
\hline & $1 \mathrm{kWh}$ & 3600 & 1 & 860 \\
\hline & $1 \mathrm{kcal}$ & 4,1868 & $1,16.10^{-3}$ & 1 \\
\hline
\end{tabular}

\begin{tabular}{|c|c|c|c|}
\hline & \multicolumn{2}{|c|}{ saída } \\
\hline & & $\mathrm{m}^{3}$ & 1 \\
\hline \multirow[t]{2}{*}{ entrada } & $1 \mathrm{~m}^{3}$ & 1 & 1000 \\
\hline & 11 & $10^{-3}$ & 1 \\
\hline
\end{tabular}


TABELA I.3 Preço dos energéticos por unidade comercial

\begin{tabular}{lcc}
\hline Fontes de energia & $\begin{array}{c}\text { Unidade comercial } \\
{[\mathrm{uc}]}\end{array}$ & $\begin{array}{c}\text { Preço/uc } \\
{[\mathrm{US} \$ \mathrm{uc}]}\end{array}$ \\
\hline Álcool hidratado & $\mathrm{I}$ & 0,30 \\
Bagaço de cana & tb & 7,87 \\
Gasolina (média) & $\mathrm{I}$ & 0,40 \\
Óleo diesel & $\mathrm{I}$ & 0,21 \\
Energia elétrica - A2 azul & $\mathrm{kWh}$ & 0,043 \\
\hline
\end{tabular}

Fonte: CAVALCANTI (1994).

Nota: Valores médios referentes a 1991.

TABELA I.4 Quantidade de energia por unidade comercial

\begin{tabular}{lcc}
\hline Fontes de energia & $\begin{array}{c}\text { Unidade comercial } \\
{[\mathrm{uc}]}\end{array}$ & $\begin{array}{c}\text { Energia/uc } \\
{\left[10^{3} \mathrm{GJ} / \mathrm{uc}\right]}\end{array}$ \\
\hline Açúcar & $\mathrm{kg}$ & $15,072.10^{-6}$ \\
Álcool anidro & $\mathrm{I}$ & $21,194.10^{-6}$ \\
Álcool hidratado & $\mathrm{I}$ & $20,155.10^{-6}$ \\
Bagaço de cana & $\mathrm{tb}$ & $7,440.10^{-3}$ \\
Cana-de-açúcar (média) & $\mathrm{tC}$ & $3,839.10^{-3}$ \\
Eletricidade & $\mathrm{kWh}$ & $3,6.10^{-6}$ \\
Gasolina (média) & $\mathrm{I}$ & $32,615.10^{-6}$ \\
Óleo diesel & $\mathrm{I}$ & $36,270.10^{-6}$ \\
\hline
\end{tabular}


TABELA I.5 Massa específica, poder calorífico inferior e coeficientes de conversão

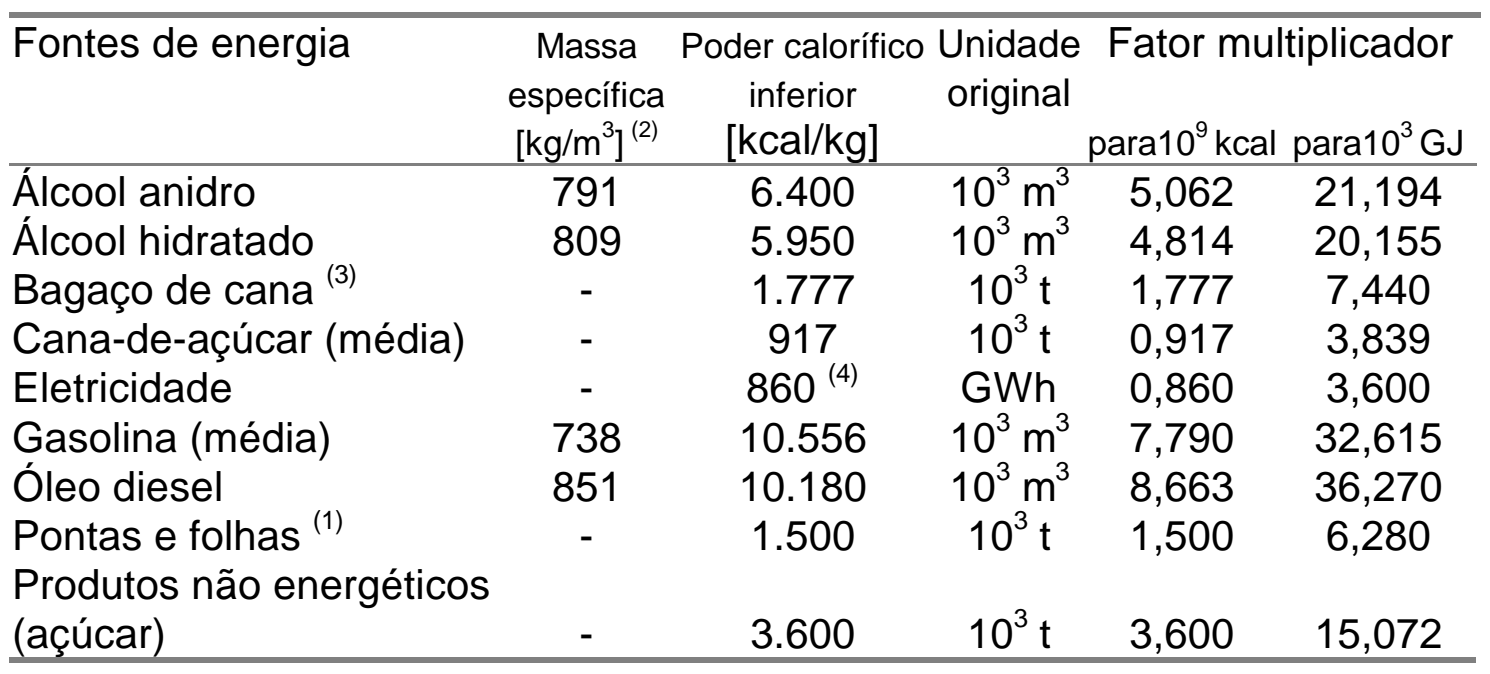

Fonte: SÃO PAULO (1992 a), p.119.

(1) PATUSCO (1985).

Notas: (2) àtemperatura de $20^{\circ} \mathrm{C}$, para os derivados de petróleo.

(3) bagaço com $50 \%$ de umidade.

(4) $\mathrm{kcal} / \mathrm{kWh}$ - energia final. 
Apêndice II - Balanço energético para o Estado de

W São Paulo, ano base 1991 
BALANÇO ENERGÉTICO PARA ।

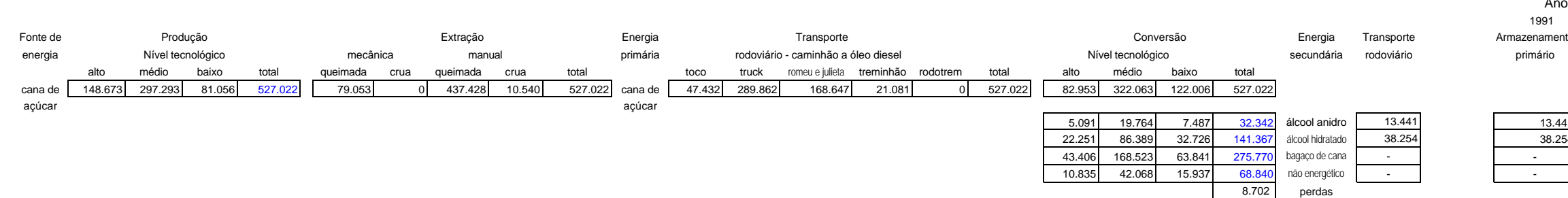

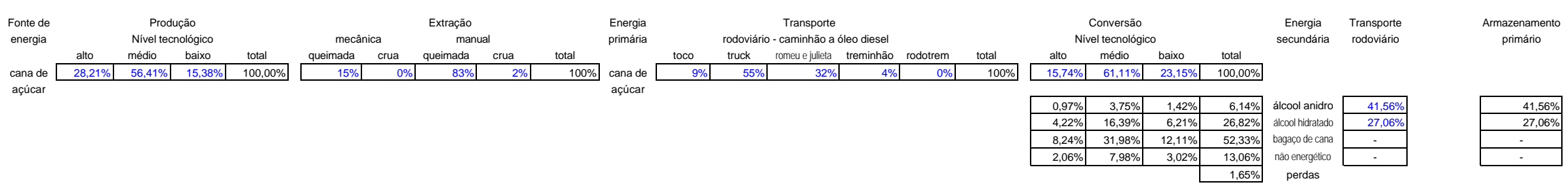
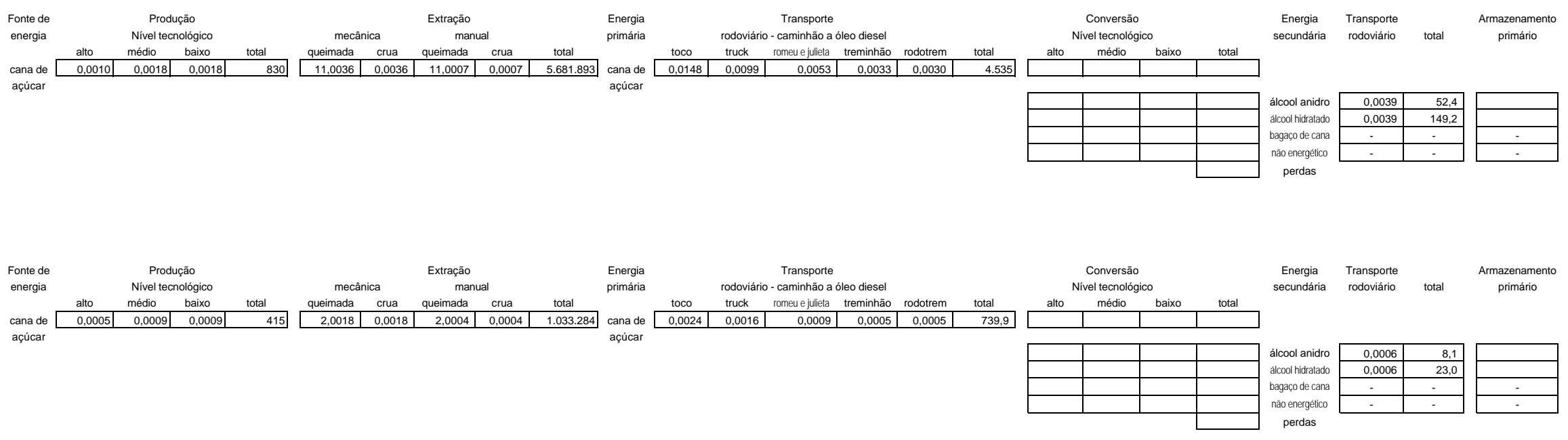


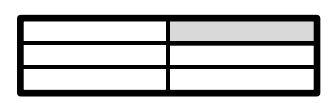




\section{O ESTADO dE SÃo PAULO}

Transportio $\begin{array}{ll}\text { rodoviário } & \text { ferroviário } \\ \text { óleo diesel obleo diesel elétrico }\end{array}$

Armazenamento Transporte Armazenamentio
secundário caminhăa a óleo diesel
pequeno médio grande transporte indústria năo setor auto exportação perdas tota

Uso final $\quad \begin{gathered}10^{3} \mathrm{G}, \\ \text { Energia }\end{gathered}$

\section{\begin{tabular}{|r|r|r|r|r|}
\hline 4.405 & 5.307 & 4.114 & 0 & 13.826 \\
\hline 15.536 & 28.584 & 12.129 & 806 & 57.056 \\
\hline- & - & - & - & - \\
\hline & - & - & - & - \\
\hline
\end{tabular}}

\begin{tabular}{|c|c|c|}
\hline 13.826 & \begin{tabular}{|r|}
13.826 \\
\end{tabular} & 13.826 \\
\hline 57.056 & \begin{tabular}{|l|}
57.056 \\
\end{tabular} & $\begin{array}{r}57.056 \\
\end{array}$ \\
\hline & & \\
\hline
\end{tabular}

\begin{tabular}{|r|r|r|r|}
\hline 1.139 & 9.011 & 3.860 & 14.009 \\
\hline 6.728 & 53.229 & 22.799 & 827 \\
\hline 2.047 & 1.36 & & \\
\hline
\end{tabular}

\begin{tabular}{r|c|c|c|}
\hline 6.728 & 53.229 & 22.799 & 82.756 \\
\hline 20.047 & 13.365 & - & 33.412 \\
\hline- & - & - & - \\
\hline
\end{tabular}

\begin{tabular}{|r|c|c|c|c|c|c|r|r|r|}
\hline 14.009 & - & - & - & & & - & 18.009 & 323 & 32.342 \\
\hline 82.756 & - & - & - & & & - & 57.197 & 1.414 & 141.367 \\
\hline- & 1.655 & 157.465 & 1.379 & 12.961 & 85.764 & 2.758 & 0 & 13.789 & 275.770 \\
\hline- & - & - & - & 30.492 & - & - & 38.004 & 344 & 68.840 \\
\hline
\end{tabular}

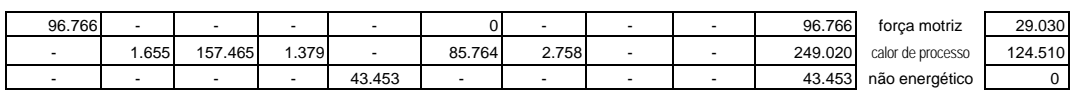

Transporte Armazenamento Transporte Armazenamento

Distribuiçăo caminhäa a a bleo diesel
pequeno

transp

ansporte indústria $\quad$ nāo setor auto exportaçăo perdas total

Uso final Energia

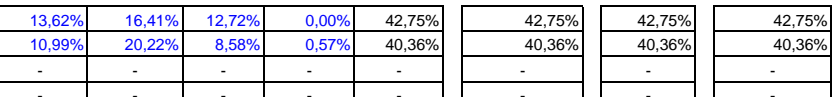

\begin{tabular}{|r|r|r|r|}
\hline $8,13 \%$ & $64,32 \%$ & $27,55 \%$ & $43,32 \%$ \\
\hline $8,313 \%$ & $64,32 \%$ & $27,55 \%$ & $58,54 \%$ \\
\hline $7,27 \%$ & $4,85 \%$ & - & $12,12 \%$ \\
\hline- & - & - & - \\
\hline
\end{tabular}

\begin{tabular}{|c|c|c|c|c|c|c|c|c|c|}
\hline $43,32 \%$ & - & - & - & & & - & $55,68 \%$ & $1,00 \%$ & $100,00 \%$ \\
\hline $58,54 \%$ & - & - & - & & & - & $40,46 \%$ & $1,00 \%$ & $100,00 \%$ \\
\hline- & $0,60 \%$ & $57,10 \%$ & $0,50 \%$ & $4,70 \%$ & $31,10 \%$ & $1,00 \%$ & $0,00 \%$ & $5,00 \%$ & $100,00 \%$ \\
\hline & - & - & - & $44,29 \%$ & - & - & $55,21 \%$ & $0,50 \%$ & $100,00 \%$ \\
\hline
\end{tabular}

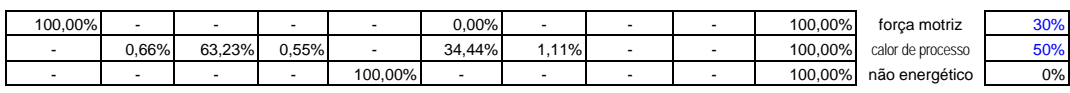

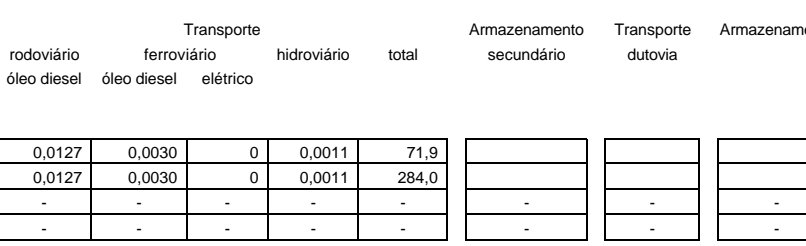

Distribuiçăo caminhăa a áleo diesel
pequeno médio grando

total

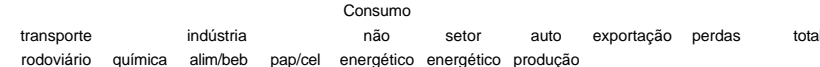

Uso final
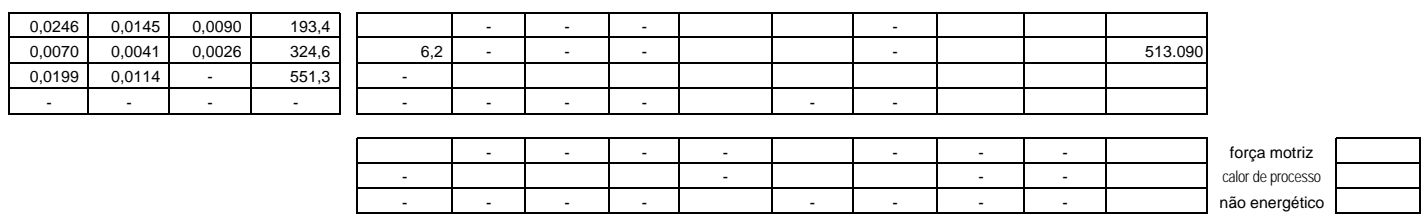

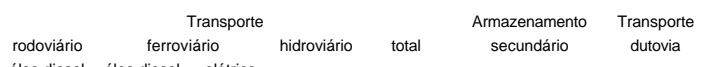

Distribuição caminhäo a óleo diesel

total

transporte

\section{Consumo}

$\mathrm{tHC} / 10^{3} \mathrm{GJ}$

\begin{tabular}{|c|c|r|r|r|}
\hline 0,0021 & 0,0021 & 0 & 0,0006 & 20,4 \\
\hline 0,0021 & 0,0021 & 0 & 0,0006 & 93,1 \\
\hline & - & - & - & - \\
\hline & - & - & - & - \\
\hline
\end{tabular}

\begin{tabular}{|l|l|l|r|}
\hline 0,0040 & 0,0024 & 0,0015 & 32,0 \\
\hline 0,0011 & 0,0007 & 0,0004 & 53,8 \\
\hline 0,0032 & 0,0019 & - & 89,5 \\
\hline
\end{tabular}

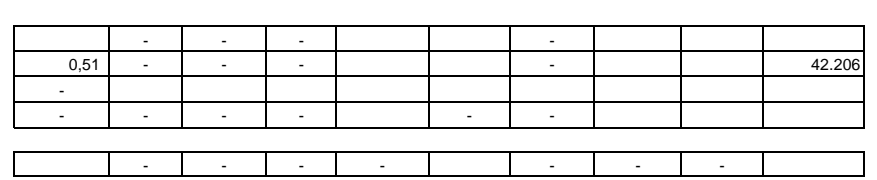




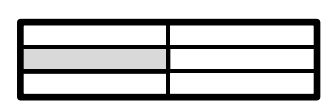



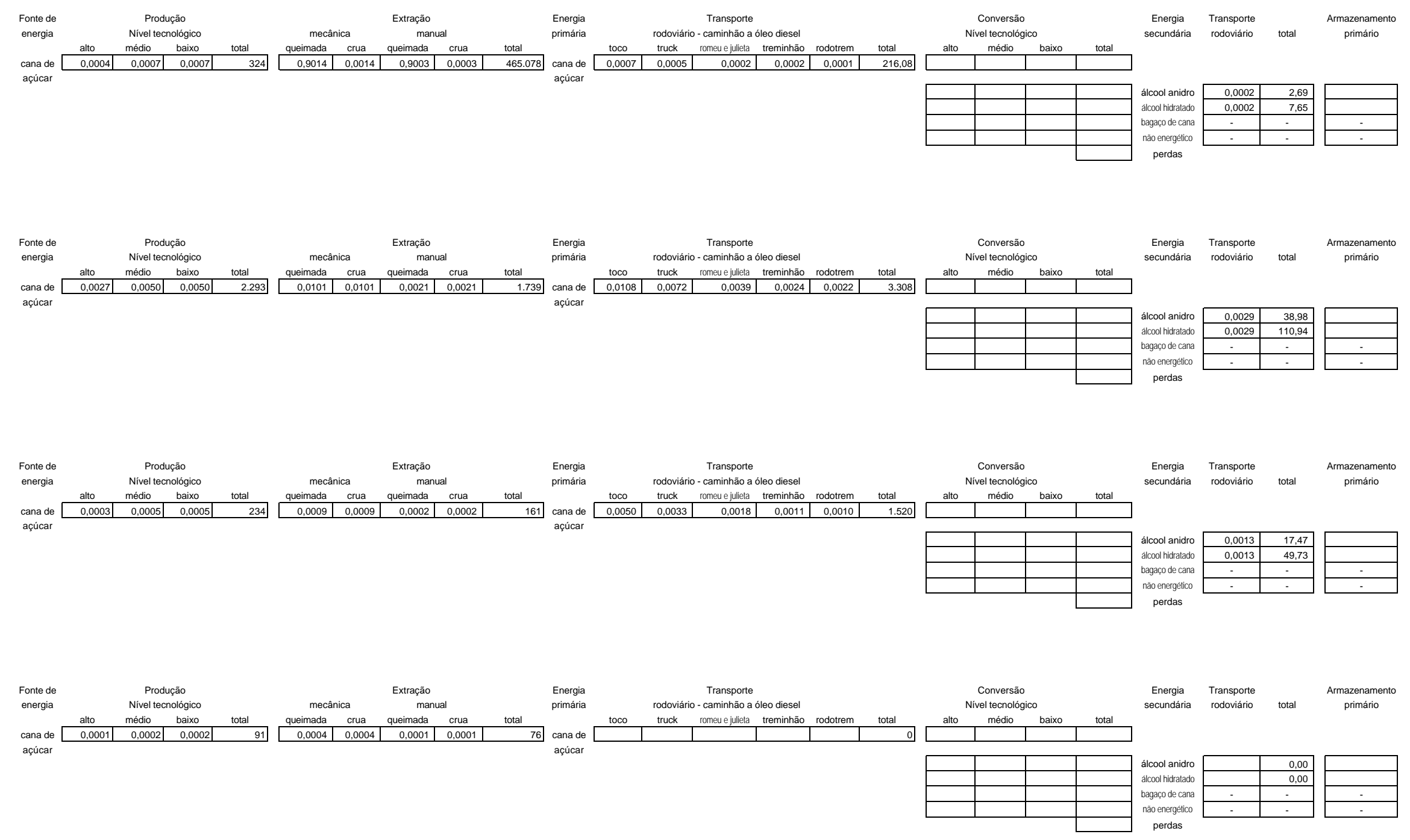


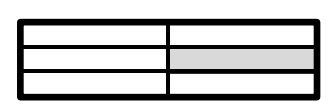



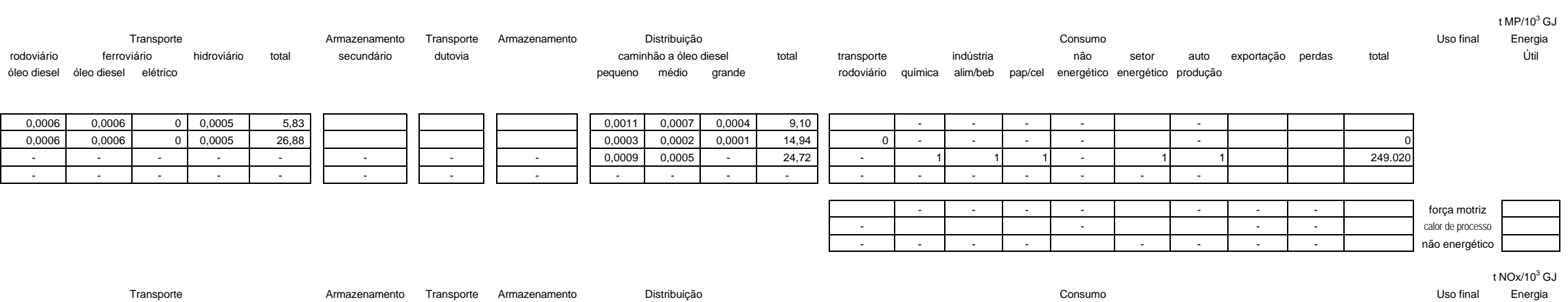


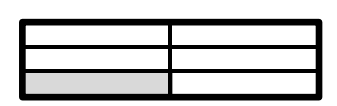



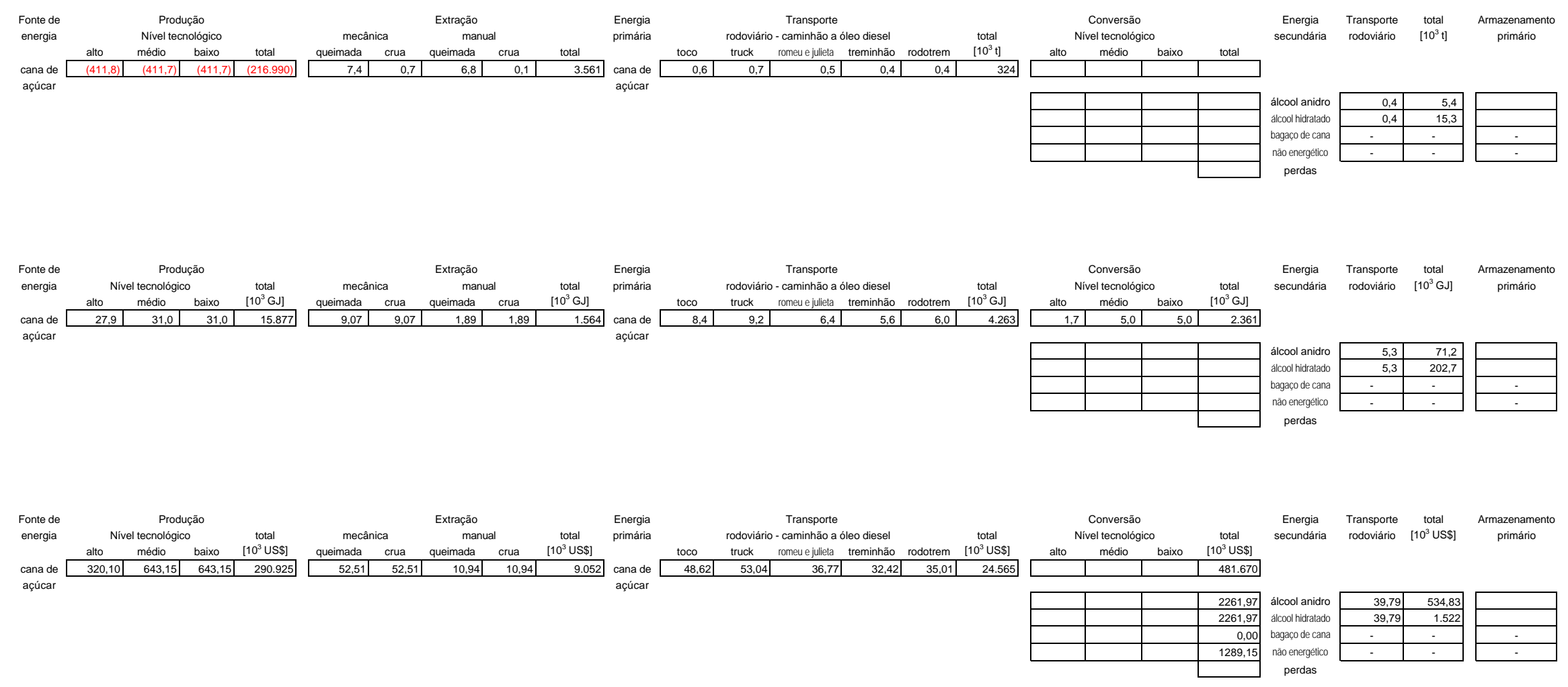


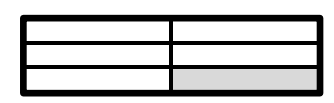




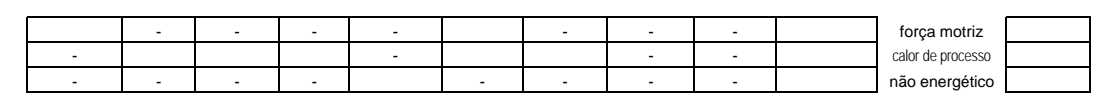

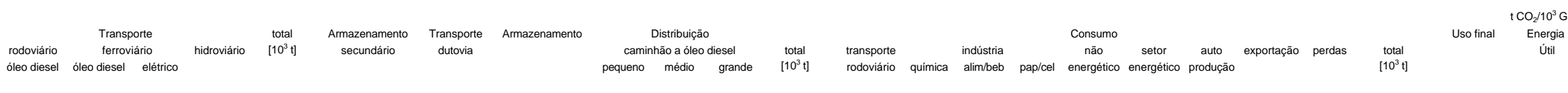

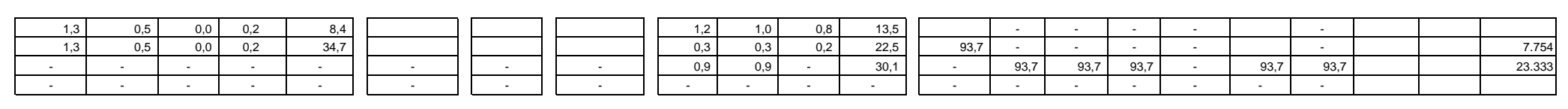

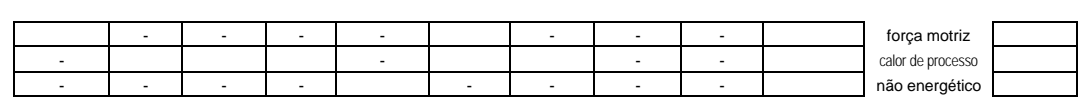

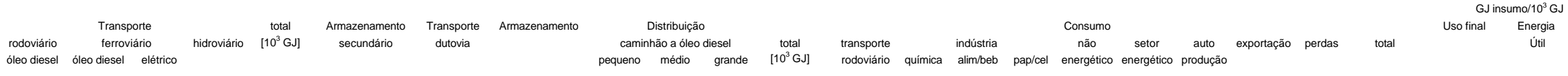
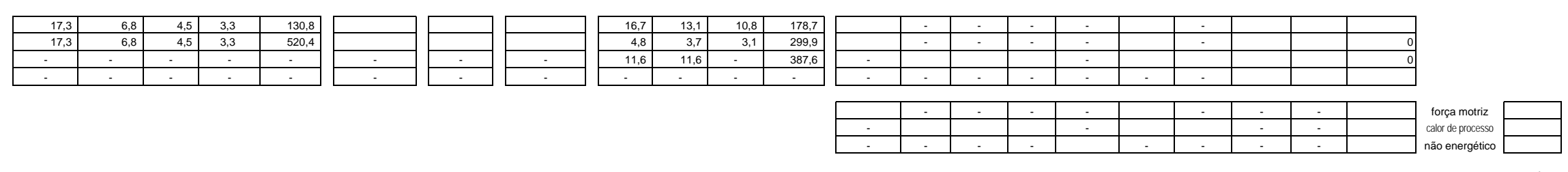

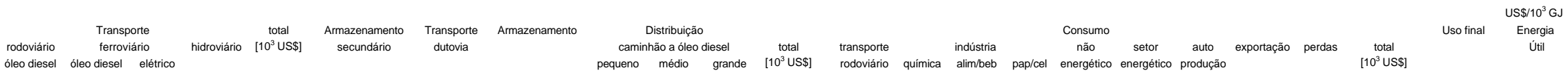

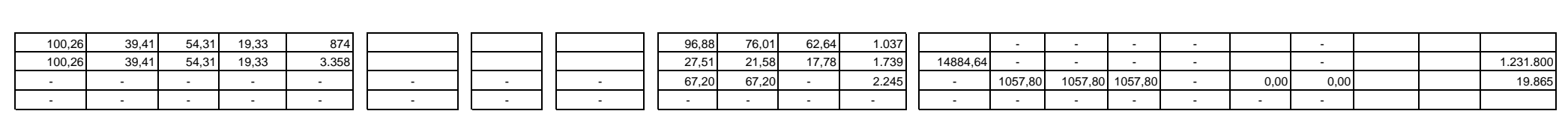

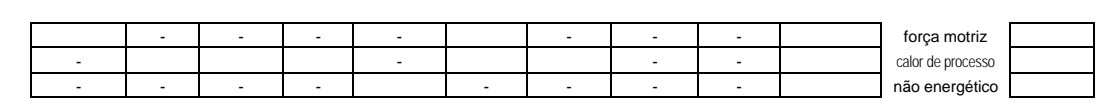

